\title{
Characterization of anticoagulant functions of protein S
}

Citation for published version (APA):

Maurissen, L. F. A. (2009). Characterization of anticoagulant functions of protein S. [Doctoral Thesis, Maastricht University]. Maastricht University. https://doi.org/10.26481/dis.20090218lm

Document status and date:

Published: 01/01/2009

DOI:

10.26481/dis.20090218Im

Document Version:

Publisher's PDF, also known as Version of record

\section{Please check the document version of this publication:}

- A submitted manuscript is the version of the article upon submission and before peer-review. There can be important differences between the submitted version and the official published version of record.

People interested in the research are advised to contact the author for the final version of the publication, or visit the DOI to the publisher's website.

- The final author version and the galley proof are versions of the publication after peer review.

- The final published version features the final layout of the paper including the volume, issue and page numbers.

Link to publication

\footnotetext{
General rights rights.

- You may freely distribute the URL identifying the publication in the public portal. please follow below link for the End User Agreement:

www.umlib.nl/taverne-license

Take down policy

If you believe that this document breaches copyright please contact us at:

repository@maastrichtuniversity.nl

providing details and we will investigate your claim.
}

Copyright and moral rights for the publications made accessible in the public portal are retained by the authors and/or other copyright owners and it is a condition of accessing publications that users recognise and abide by the legal requirements associated with these

- Users may download and print one copy of any publication from the public portal for the purpose of private study or research.

- You may not further distribute the material or use it for any profit-making activity or commercial gain

If the publication is distributed under the terms of Article $25 \mathrm{fa}$ of the Dutch Copyright Act, indicated by the "Taverne" license above, 
Characterization of anticoagulant functions of protein $\mathbf{S}$ 
Characterization of anticoagulant functions of protein $\mathbf{S}$ ISBN:978-90-9023981-1

(c) Lisbeth Maurissen, Maastricht 2009

Druk: Print and Copy Service Moons, Hasselt

Omslag: Jan Bastiaens 


\title{
Characterization of anticoagulant functions of protein S
}

\author{
PROEFSCHRIFT \\ ter verkrijging van de graad van doctor \\ aan de Universiteit Maastricht \\ op gezag van de Rector Mangnificus, \\ Prof. Mr G.P.M.F. Mols, \\ volgens het besluit van het College van Decanen \\ in het openbaar te verdedigen \\ op woensdag 18 februari 2009 om 14.00
}

Door

Lisbeth Fernande Angèle Maurissen 
PROMOTOREN

Prof. Dr. J. Rosing

Prof. Dr. T.M. Hackeng

BEOORDELINGSCOMMISSIE

Prof. Dr. A. Bast (voorzitter)

Prof. Dr. J.W. Cohen Tervaert

Prof. Dr. M. van Dieijen-Visser

Dr. R.R. Koenen (RTWH Aachen)

Prof. Dr. J.C.M. Meijers ( AMC, Amsterdam) 


\section{CONTENTS}

Chapter 1 Blood coagulation and regulation by the anticoagulant proteins TFPI and protein $S$

Chapter 2 Re-evaluation of the role of the protein S-C4b binding protein complex in activated protein C-catalyzed factor Va-inactivation

Chapter 3 A thrombin generation-based assay for measurement of the activity of the TFPI-protein S pathway in plasma; TFPI activity is decreased in heterozygous Type-I protein S-deficient individuals

Chapter $4 \quad$ Type I and type III hereditary protein S deficiencies: Risk of venous thrombosis and underlying hypercoagulable state

Chapter 5 Effect of oral contraceptives on the down-regulation of thrombin generation by the TFPI and protein C pathways

Chapter 6 General discussion 



\section{Chapter 1}

Blood coagulation and regulation by the anticoagulant proteins TFPI and protein S 



\section{THE BLOOD COAGULATION CASCADE}

Blood coagulation, which has evolved as an important defense mechanism against bleeding, proceeds via a complex cascade ${ }^{1,2}$, which involves enzymes and cofactors that circulate as inactive precursors (or zymogens) in blood. A small trigger causes the activation of the first zymogen of the coagulation cascade into an active enzyme by limited proteolysis. Subsequently, this active enzyme activates the next blood coagulation zymogen and a cascade occurs that leads to thrombin formation. Thrombin is the key enzyme of the coagulation cascade, that performs many biologically important functions such as the activation of platelets, feedback amplification of coagulation and conversion of fibrinogen to fibrin which subsequently forms a network that stabilizes the platelet plug ${ }^{3}$.

Most of the coagulation enzymes belong to the serine protease family. For a number of coagulation factors the $\mathrm{Y}$-carboxylation of $\mathrm{N}$-terminal glutamic acid residues to $\mathrm{Y}$ carboxyglytamic acid (Gla) catalysed by the vitamin K-dependent carboxylase is of crucial importance. In vivo, coagulation is thought to occur in sequential phases; initiation, propagation and termination.

\section{The initiation phase}

Activation of blood coagulation is initiated in vivo when the sub-endothelial protein tissue factor (TF) is exposed to the flowing blood as a consequence of a damaged vessel wall 4,5 . The tissue factor-dependent activation of coagulation has traditionally been referred to as the 'extrinsic' pathway ${ }^{6-8}$. TF binds both the zymogen and activated forms of the serine protease, factor VII(a) present in blood ${ }^{9,10}$. The resulting membrane-bound TF-factor VIla complex converts the circulating zymogens factor $X$ and factor IX to their active forms (Xa and $\mid X a)^{6,11}$. Factors IXa and Xa diffuse into the blood and bind to the surface of activated platelets 12. Activation of platelets results in the exposure of negatively charged phospholipids (phosphatidylserine) at the platelet membrane, enabling binding of coagulation factors and assembly of enzyme-cofactor complexes important for efficient propagation of coagulation ${ }^{13}$. Factor $\mathrm{Xa}$ and its cofactor activated factor $\mathrm{V}$ (factor $\mathrm{Va}$ ) assemble on the activated platelets to form the prothrombinase complex that efficiently activates prothrombin to thrombin ${ }^{14-16}$. Circulating factor $\mathrm{V}$ can be activated by factor $\mathrm{X}$ a on the platelets but the majority of factor $\mathrm{V}$ is activated by the first thrombin molecules that are generated during the coagulation process 17,18 . 


\section{The Propagation Phase}

Thrombin amplifies its own generation by a positive feedback through activating not only factor $\mathrm{V}$ but also factor XI and factor VIII in the so-called propagation loops ${ }^{19-21}$. Activation of coagulation factor XI by thrombin results in the generation of additional factor IXa ${ }^{20}$. Next, factor IXa and factor VIIIa assemble into the intrinsic tenase complex. Factor VIII circulates bound to von Willebrand factor, which is an adhesive protein important for the generation of the platelet plug ${ }^{22}$. After activation by thrombin, factor VIIla dissociates from von Willebrand factor and forms the 'tenase' complex on the negatively charged phospholipids surface with factor IXa. This 'tenase' complex subsequently activates factor $\mathrm{X}$. When sufficient thrombin is generated fibrinopeptides $A$ and $B$ are cleaved from fibrinogen which results in the polymerization of fibrin monomers to a fibrin network ${ }^{23,24}$. The fibrin clot is stabilized by factor XIIla, which is activated by thrombin ${ }^{25-27}$.

\section{The Termination Phase}

Regulation of coagulation takes place at each phase, either by enzyme inhibition or by modulation of the activity of the coagulation cofactors. The major anticoagulant pathways are controlled by four plasma proteins (antithrombin, TFPI, protein C and protein S), which inactivate either serine proteases or their cofactors.

Most of the enzymes generated during activation of coagulation are inhibited by the serine-protease inhibitor antithrombin ${ }^{28}$, previously known as antithrombin III. Antithrombin preferentially inhibits free enzymes of the coagulation system, whereas enzymes that are part of the tenase or prothrombinase complexes are protected for inhibition by antithrombin ${ }^{29}$. The physiological role of antithrombin is to limit the coagulation process to sites of vascular injury and to prevent the unwanted circulation of coagulation enzymes. The activity of antithrombin is greatly stimulated by heparin and heparin-like molecules ${ }^{30}$.

Tissue factor pathway inhibitor (TFPI) targets factor Xa and the lipid-bound factor VIlaTF-factor Xa complex and thereby regulates the initiation phase of coagulation ${ }^{31-33}$. Inhibition of factor Xa by TFPI is accelerated by its cofactor, protein $\mathrm{S}^{34}$. No deficiency states have been described in humans, suggesting that deficiencies of TFPI are not compatible with life ${ }^{35}$. 


\section{Procoagulant system Anticoagulant system}

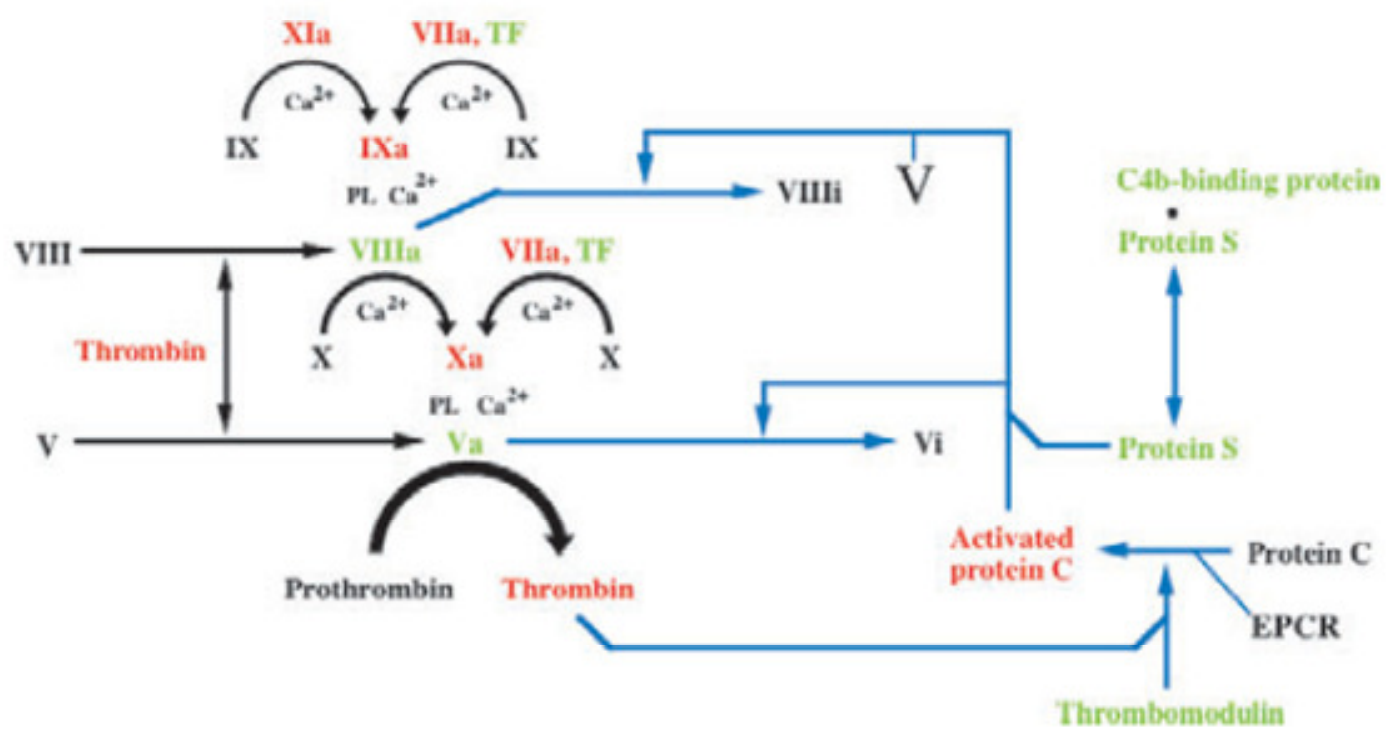

Figure 1.1: Schematic representation of the reactions of blood coagulation and the protein C anticoagulant system. The exposure of TF to blood and the subsequent binding of factor VIla to TF result in the initiation of blood coagulation. The factor VIla-TF complex activates factor IX and factor X. Factor IX is alternatively activated by factor Xla, which can be generated as a result of activation of the contact system or by feedback activation of factor XI by thrombin. Factor IXa and factor VIIla form the tenase complex in the presence of calcium and negatively-charged phospholipid membranes and factor $X a$ and factor $V a$ form the prothrombinase complex. Thrombin feedback activates coagulation by activation of factor VIII and factor V. Thrombin has multiple procoagulant functions such as activation of platelets, conversion of fibrinogen to fibrin and activation of factor XIII. In the presence of intact endothelium, thrombin binds to thrombomodulin and activates protein C. Endothelial protein $C$ receptor (EPCR) stimulates the activation of protein C. Activated protein C inhibits coagulation by cleaving and inactivating the cofactors factor Va and factor VIIla. The free form of protein $\mathrm{S}$ in blood serves as cofactor to activated protein C. (Figure taken from Dahlbäck B, Journal of Internal Medicine, 2005; 257: 209-223)

The protein $\mathrm{C}$ system down-regulates coagulation by modulation of the activity of factors VIIla and $\mathrm{Va}^{36}$. Protein $\mathrm{C}$ is activated on the surface of endothelial cells by thrombin bound to the membrane receptor thrombomodulin ${ }^{37}$. In this way, thrombin has the capacity to express both procoagulant and anticoagulant functions depending on the situation under which it is generated. Activated protein C (APC) inactivates the membrane-bound cofactors VIIla and Va through proteolytic cleavage, which results in inhibition of thrombin generation 38. Protein S, a vitamin-K-dependent cofactor, stimulates the anticoagulant activity of APC. It has been proposed that APC and protein S form a membrane bound complex, in which protein S stimulates cleavage of factors VIIla and Va, even when they are part of fully assembled tenase and prothrombinase complexes ${ }^{39,40}$. APC does not cleave intact factor VIII in vivo, but 
can cleave the intact form of factor $\mathrm{V}$. Cleaved factor $\mathrm{V}$ functions in synergy with protein $\mathrm{S}$ as an APC cofactor in the inactivation of factor VIIla ${ }^{41,42}$.

The physiological importance of the protein C/protein $S$ system is shown by the severe thrombotic disease that is associated with homozygous deficiency of protein $\mathrm{C}$ or protein $\mathrm{S}$ known as Purpura Fulminans that manifests shortly after birth ${ }^{43-45}$.

\section{PROTEIN S}

\section{Synthesis of protein $S$}

Protein $\mathrm{S}$ is a vitamin $\mathrm{K}$-dependent plasma glycoprotein which has a molecular weight of $\sim 75 \mathrm{kDa}{ }^{46}$. In humans, protein $\mathrm{S}$ is mainly synthesized by hepatocytes, but also by megakaryocytes, endothelial cells, Leydig cells of testis, osteoblasts and vascular smooth muscle cells ${ }^{47-52}$.

Human protein $S$ is expressed from the gene PROS1 that is located near the centromere on chromosome 3 (region 3q11.2) ${ }^{53,54}$. The genomic sequence of PROS1 currently encompasses exons 1 to 15 and exhibits 97\% homology with the pseudogene PROS2, which is present at 3p21-cen. ${ }^{55,56}$. Only the gene PROS1 is transcribed, while pseudogene PROS2 lacks the $5^{\prime}$ exon containing the initiation methionine, it has a splice site mutation, several stop codons and a frame shift mutation ${ }^{56}$.

Protein S, which is homologous to the other vitamin K-dependent coagulation factors 57,58 , is synthesized as a precursor of 676 amino acids of which $41 \mathrm{~N}$-terminal residues are represented as the 'proleader'. The proleader contains a signal peptide and a propeptide. During posttranslational modification, the signal peptide directs the protein to the lumen of the endoplasmic reticulum. After signal peptide cleavage, the propeptide, containing the $\mathrm{\gamma}$ carboxylation recognition site, binds to the vitamin $\mathrm{K}$ dependent carboxylase associated within the endoplasmic reticulum. Specific glutamic acids are converted to $\gamma$-carboxyglutamic acids and the propeptide is proteolytically removed before secretion ${ }^{58}$.

After synthesis protein $S$ is subjected to additional posttranslational modifications, including disulfide bond formation, $\mathrm{N}$-linked glycosylation and $\beta$-hydroxylation of asparagine and aspartic acid residues, required for anticoagulant function ${ }^{59}$.

Protein S circulates in plasma at a concentration of approximately $350 \mathrm{nM} .60 \%$ of protein $\mathrm{S}$ is tightly bound in a 1:1 complex to C4b-binding protein (C4BP) ${ }^{60}$, the remaining protein $\mathrm{S}$ circulates as a free form ${ }^{61}$. 


\section{Structure of protein $S$}

To date, protein $\mathrm{S}$ has not yet been crystallized and a complete three dimensional structure has not yet been reported. Mature protein $\mathrm{S}$ is a single-chain molecule and has a modular structure consisting of a Gla domain (residues 1-46) containing a short aromatic stack (residues 38-46), a region sensitive to cleavage by thrombin and factor Xa (TSR; residues 4775), 4 epidermal growth factor (EGF)-like domains (EGF 1-4, residues 76-242) ${ }^{62}$, and a sex hormone binding globulin (SHBG)-like region, containing 2 laminin G-type repeats (LGR; residues $243-635)^{63}$.

The Gla-domain of protein S contains $11 \gamma$-carboxylated glutamic acid (Gla) residues. These Gla-residues are able to bind to multiple $\mathrm{Ca}^{2+}$-ions and the $\mathrm{Ca}^{2+}$-stabilized structure has a high affinity for negatively charged phospholipid membranes ${ }^{64,65} \cdot \mathrm{Ca}^{2+}$-ions have been shown to induce conformational changes in Gla-domains ${ }^{66}$ and mediate a regulated exposure of hydrophobic resides for membrane interactions in various ways ${ }^{67}$, which lead to increased binding to phospholipids ${ }^{68}$. Incomplete carboxylation of the Gla-domain or mutations in the Gla domain will lead to dysfunctional protein $S^{69,70}$.

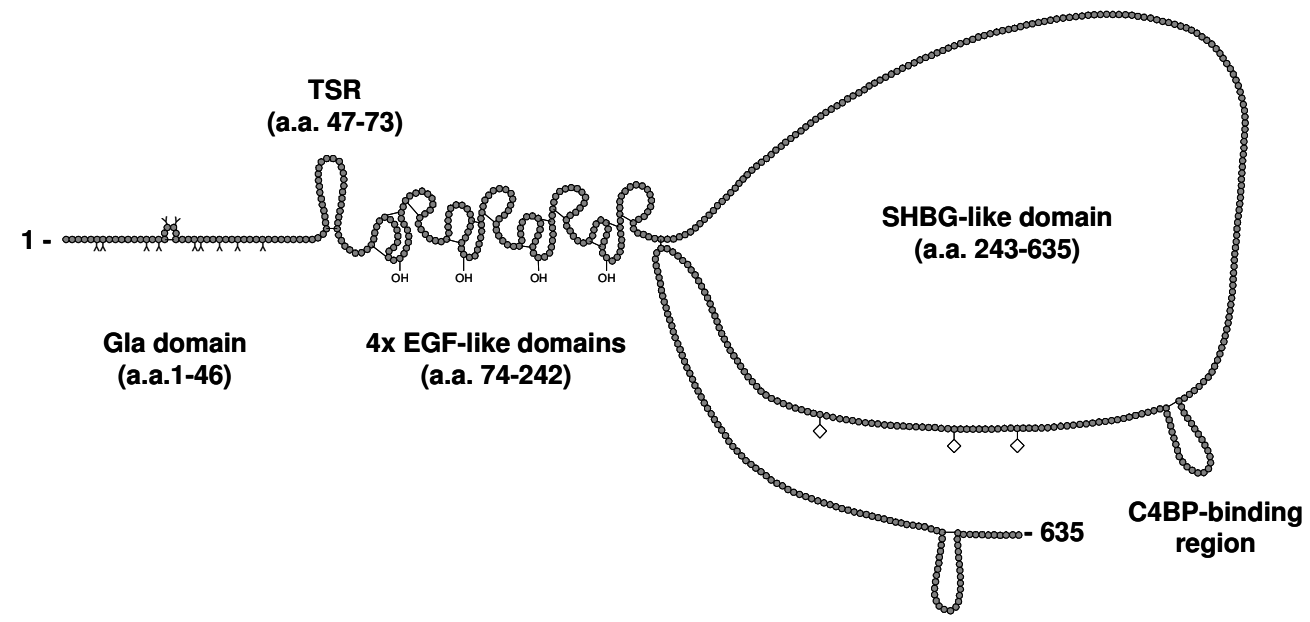

Figure 1.2: Modular structure of protein S. Protein $S$ consists of 635 amino acids which are organized in the following modules. The phospholipid-binding Gla domain (Gla) (a.a.1-46), a thrombin sensitive region (TSR) (a.a.47-73), four EGF-like domains (EGF 1-4) (a.a.74-242) and a sex hormone binding globulin-like domain (SHBG) containing two laminin G (LG)-type domains (a.a.243-635).

The Gla-domain is followed by the thrombin sensitive region (TSR) containing a disulfide-bridge (residues 46-75). Two peptide bonds in the TSR ( $\operatorname{Arg}^{49}$ and $\operatorname{Arg}^{70}$ ) are sensitive to proteolysis by thrombin ${ }^{71-73}$. After cleavage of these bonds, the Gla-domain remains attached to the rest of protein $\mathrm{S}$ via a disulfide bond, but its affinity for $\mathrm{Ca}^{2+}$-ions is decreased ${ }^{71}$. Thrombin-cleaved protein $\mathrm{S}$ and intact protein $\mathrm{S}$ have comparable affinities for negatively 
charged phospholipid membranes ${ }^{74}$. The TSR of protein $S$ is required for the Gla-domain of protein $S$ to bind to phospholipids. Deletion of the TSR in a recombinant protein $S$ variant leads to defective phospholipid binding ${ }^{75,76}$. The anticoagulant activity of protein $S$ is lost when protein $\mathrm{S}$ is cleaved at $\mathrm{Arg}^{49}$ by thrombin ${ }^{77,78}$. The TSR domain can also be cleaved by factor Xa at $\mathrm{Arg}^{60}$ in the presence of $\mathrm{Ca}^{2+}$-ions, and APC-cofactor activity is lost ${ }^{79}$. Factor Xacleaved protein $\mathrm{S}$ has been detected in plasma ${ }^{80,81}$.

Protein S contains four epidermal growth factor (EGF)-like modules (residues 73-242), which are directly involved in protein-protein interactions ${ }^{82}$. The EGF-like domains of protein $\mathrm{S}$ contain $\mathrm{Ca}^{2+}$-binding sites ${ }^{83}$. The third and fourth EGF modules in protein $\mathrm{S}$ have very high affinity $\mathrm{Ca}^{2+}$-binding sites in the nanomolar range and are involved in the interaction with factor $\mathrm{X}^{84-86}$. Binding of $\mathrm{Ca}^{2+}$ to EGF module 4 of protein $\mathrm{S}$ is important for the maintenance of the conformation of protein $S^{87}$. EGF-like modules 1 and 2 are important for APC-cofactor activity and are involved in interaction between protein $\mathrm{S}$ and $\mathrm{APC}{ }^{88-90}$.

The carboxy-terminus SHBG domain of protein S, which shows $30 \%$ sequence identity with plasma sex hormone binding globulin, is unique because this domain replaces the serine protease domain found in other vitamin K-dependent coagulation factors and appears to be devoid of enzymatic activity ${ }^{63}$. The SHBG domain of protein S contains two laminin G-like domains each containing an internal disulfide bridge. Protein $\mathrm{S}$ is related to other Laminin Glike domain consisting proteins such as Gas6 ${ }^{91,92}$, which is the ligand of receptor tyrosine kinases of the Axl/Tyro3 family.

Approximately $60 \%$ of the protein $\mathrm{S}$ present in plasma is bound to the $\beta$-chain of $\mathrm{C} 4 \mathrm{~b}$ binding protein (C4BP) ${ }^{93-95}$, a member of the classical complement pathway. C4BP is a high molecular weight plasma protein of $570 \mathrm{kDa}$ with a plasma concentration of 200nM. C4BP was found to have an unusual spider-like structure ${ }^{96}$, it consists of seven $\alpha$-chains and one $\beta$ chain, which are held together by disulfide bonds in a central core ${ }^{97,98}$. The $\alpha$-chains (Mw 70 $\mathrm{kDa}$ ) are composed of eight homologous domains called short consensus repeats (SCRs) ${ }^{99}$. The $\beta$-chain ( $M w 45 \mathrm{kDa}$ ) of C4BP is composed of three SCR units. The protein $\mathrm{S}$ binding site is localized in the central core of C4BP ${ }^{100}$, studies have shown that protein $\mathrm{S}$ binds to the $\mathrm{N}$ terminal SCR unit (SCR-1) of the $\beta$-chain ${ }^{95,101-104}$. In addition the second SCR unit contributes to the interaction of C4BP with protein $\mathrm{S}^{105}$. Protein $\mathrm{S}$ binds to C4BP with a very high affinity and forms a $1: 1$ complex which has a $\mathrm{K}_{\mathrm{D}}$ of $0.9 \times 10^{-9} \mathrm{M}^{60,101,106}$. Residues $423-429^{101,102}$ and residues $453-460{ }^{107}$ of protein $S$ are involved in binding to C4BP. 


\section{Anticoagulant functions of protein $S$.}

Protein $\mathrm{S}$ has multiple anticoagulant functions. The best known and studied function of protein $\mathrm{S}$ is its ability to act as a cofactor of APC. More recently it has been reported that protein $\mathrm{S}$ also expresses cofactor activity for TFPI.

\section{APC-cofactor activity of protein S.}

The protein C pathway exerts its anticoagulant effect by down-regulating the activity of factor VIIla and factor Va, the cofactors of factor IXa and factor Xa, respectively ${ }^{108}$.

Protein C is a vitamin K-dependent glycoprotein $(62 \mathrm{kDa}){ }^{109}$ which circulates as a precursor of the serine protease, activated protein C (APC) ${ }^{110,111}$. The plasma protein $C$ concentration is $70 \mathrm{nM}$, while plasma also contains $40 \mathrm{pM}$ of the activated form APC ${ }^{112}$. APC is a multi domain protein, composed of a light chain and a heavy chain, linked by a disulfide bond ${ }^{109}$.

Protein $C$ is activated by thrombin bound to the receptor protein thrombomodulin (TM), which is expressed on endothelial cells ${ }^{113}$. The thrombin-TM mediated activation of protein $C$ on the endothelial cell surface is stimulated by the endothelial protein $C$ receptor (EPCR) ${ }^{114-116}$ that binds to the Gla-domain of protein $\mathrm{C}$. The activation peptide of protein $\mathrm{C}$ is released during the activation by the thrombin-TM-EPCR complex, and the serine protease domain is converted to its active conformation. Protein $C$ activation is down-regulated by the thrombin inhibitor antithrombin, which efficiently inhibits TM-bound thrombin ${ }^{37,117}$. In addition, APC and APC bound to EPCR ${ }^{113}$ are down regulated by plasma protease inhibitors (protein $C$ inhibitor, $\alpha_{1}$-antitrypsin) with a half-life of $\sim 15$ minutes ${ }^{118,119}$. It was reported that the EPCR-APC complex activates protease activated receptor (PAR-1) causing cell signaling and gene expression alteration ${ }^{120}$.

Activated protein C (APC) anticoagulant activity involves the proteolytic inactivation of coagulation factors VIIIa ${ }^{121,122}$ and $\mathrm{Va}^{123-125}$, which results in the down-regulation of coagulation. The loss of cofactor activity of factor $\mathrm{Va}$ is associated with peptide bond cleavages in the heavy chain of factor $\mathrm{Va}$ at $\mathrm{Arg}^{306}, \mathrm{Arg}^{506}$ and $\mathrm{Arg}^{679}{ }^{126,127}$. Factor $\mathrm{Va}$ inactivation by APC proceeds via biphasic reaction; a rapid proteolysis at $\mathrm{Arg}^{506}$ that results in the formation of an intermediate which expresses a reduced cofactor activity in prothrombin activation, followed by a slow proteolysis at $\mathrm{Arg}^{306}$ which leads to full inactivation of factor $\mathrm{Va}$. The slow rate of cleavage at $\operatorname{Arg}^{679}$ is not considered to be of physiologic relevance ${ }^{128}$. The rate of inactivation of factor Va by APC is greatly enhanced by the presence of calcium ions, negatively charged phospholipids ${ }^{124,129}$ and its cofactor protein $\mathrm{S}^{39,125,130}$. 
APC resistance was discovered as an in vitro phenomenon that is characterized by a poor anticoagulant response of plasma to APC. This phenomenon was first reported by Dahlbäck et al., who found that plasmas of a group of patients with a family history of venous thrombosis showed reduced anticoagulant response to the addition of APC ${ }^{131}$. About one year later a number of laboratories ${ }^{132-134}$ showed that a common polymorphism, which is characterized by the replacement of $\operatorname{Arg}^{506}$ by glutamine, is responsible for APC resistance. The inactivation of the mutated molecule (called factor $V_{\text {Leiden }}$ ) by APC is impaired and proceeds exclusively through proteolysis at $\mathrm{Arg}^{306}$.

APC-mediated proteolysis at $\mathrm{Arg}^{306}$ of factor $\mathrm{Va}$ and factor $\mathrm{Va}_{\text {Leiden }}$ is enhanced approximately 20 -fold by protein S, while proteolysis at $\mathrm{Arg}^{506}$ is not affected ${ }^{135}$. However, effects of protein $\mathrm{S}$ on $\mathrm{Arg}^{506}$ cleavage by APC that have been reported later are most likely explained by different phospholipid compositions ${ }^{40,136}$. Factor $X a$ is known to inhibit the APCmediated inactivation of factor $\mathrm{Va}{ }^{124,126,137}$, which on its turn is counteracted by protein $\mathrm{S}^{39}$. The mechanism by which protein S stimulates APC is still not yet fully understood. Optimal proteolysis of factor $\mathrm{Va}$ by protein $\mathrm{S}$ requires the presence of a negatively charged phospholipids surface ${ }^{130,138}$. In addition, a functional Gla module, intact TSR and EGF1 of protein S interact with APC and increase the affinity of APC for phospholipid surface ${ }^{139,140}$. It was also reported that protein S relocates the active site of phospholipid-bound APC above the membrane surface, by binding of the first epidermal growth factor domain of protein $\mathrm{S}$ to APC $^{89,141,142}$.

When protein $\mathrm{S}$ is cleaved by thrombin or factor Xa in the TSR domain, no cofactor activity for APC is observed ${ }^{71,72,79,80}$. It was reported that binding of C4BP to protein $\mathrm{S}$ resulted in loss of cofactor activity for APC ${ }^{143-146}$ and that C4BP also inhibited inactivation of factor Va by $A P C$ in the absence of protein $S^{147}$.

Limited proteolysis of factor VIIlla by APC occurs at amino acid positions $\operatorname{Arg}^{336}, \operatorname{Arg}^{562}$ and $\mathrm{Arg}^{740148}$. In addition to its procoagulant function in prothrombin activation, factor $\mathrm{V}$ acts together with protein $S$ as synergistic cofactors in the degradation of factor VIIla ${ }^{149-151}$. To express APC cofactor activity, factor $\mathrm{V}$ must retain the B-domain and must be cleaved by APC

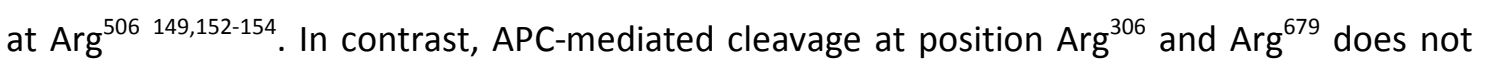
result in the expression of factor $\mathrm{V}$ anticoagulant activity ${ }^{42}$. Protein $\mathrm{S}$ enhances the inactivation of purified factor VIIla by APC ${ }^{155,156}$ and C4BP had no effect on the protein S cofactor activity in APC-mediated inactivation of factor VIIIa ${ }^{157}$. 


\section{APC-independent cofactor activity of protein S.}

In the first report of the APC-independent anticoagulant activity of protein S, direct inhibition of prothrombin activation by purified protein $\mathrm{S}$ was described ${ }^{158}$. Protein $\mathrm{S}$ was reported to inhibit prothrombin activation through direct interactions with factor $\mathrm{Va}$ and factor Xa ${ }^{159-161}$. In addition, it was shown that protein $\mathrm{S}$ competes with prothrombin for binding to factor $\mathrm{Va}^{159}$. C-terminal residues $621-635$ of protein $\mathrm{S}$ were reported to be essential for binding to factor $\mathrm{Va}^{162}$. Protein $\mathrm{S}$ cleaved by factor Xa has still APC-independent activity, while protein S cleaved by thrombin does not express APC-independent anticoagulant activity 163 .

The ability of protein $S$ to bind to phospholipids is crucial for the expression of anticoagulant activity in the absence of APC ${ }^{161,164,165}$. This was demonstrated by the observation that a monoclonal antibody directed against the $\gamma$-carboxyglutamic acid (Gla) module of protein S inhibited its APC-independent anticoagulant activity ${ }^{138,164}$. At limiting phospholipids, protein $\mathrm{S}$ can also directly inhibit prothrombinase activity by competing for phospholipid surface ${ }^{165}$. This was later explained by the presence of multimeric forms of protein $S$ that bind with a high affinity to negatively charged phospholipid surfaces ${ }^{166}$.

Differences in APC-independent anticoagulant activities between different protein S preparations ${ }^{158-161}$ are caused by different amounts of multimeric protein $S$ forms in the purified protein $\mathrm{S}$ purifications. These protein $\mathrm{S}$ multimers are generated during purification of protein S from plasma ${ }^{166}$. Protein S multimers are absent in plasma ${ }^{167}$, although a contradictory report exists ${ }^{168}$. These multimeric forms of protein $\mathrm{S}$, which constitute a small fraction of total protein S (2-5\%), have a 100 -fold higher APC-independent anticoagulant activity than the monomeric form of protein $\mathrm{S}^{166}$.

APC-independent activity of protein $\mathrm{S}$ was also observed in plasma. When plasma protein $S$ was neutralized with antibodies against protein $S$, thrombin generation was markedly increased ${ }^{169-171}$. Furthermore, it was shown that the APC-independent anticoagulant activity of protein $S$ in plasma is reduced in women using oral contraceptives ${ }^{172}$ and in patients with the prothrombin G20210A mutation ${ }^{170}$. Recently, it was reported that protein $S$ acts as a cofactor for TFPI in the down-regulation of factor X-activation ${ }^{34}$.

\section{TFPI-cofactor activity of protein S.}

Tissue factor pathway inhibitor (TFPI) is a multivalent Kunitz-type inhibitor of 276 amino acids, including 18 cysteines that are all involved in disulfide bonds. TFPI consists of a 
highly negatively charged $\mathrm{N}$-terminal domain, 3 Kunitz-type domains and a lysine rich $\mathrm{C}$ terminal tail ${ }^{173}$. Despite the variability in mRNA size and sequence due to multiple alternative transcriptional start sites, the primary product is the well-characterized full length TFPI protein that is translated from what is now referred to as the TPFla transcript ${ }^{174}$. An alternative spliced variant of TFPI has been identified as TFPI $\beta$ and has a different C-terminal tail, a GPI anchor that associates with the endothelial cell surface ${ }^{175,176}$.

TFPI-2 is a 32 kDa matrix-associated Kunitz-type serine protease inhibitor consisting of a short amino-terminal region. Human TFPI-2 was referred to as placental protein 5 (PP5) ${ }^{177}$ and is thought to play a role in the regulation of extracellular matrix digestion and remodeling 178 .

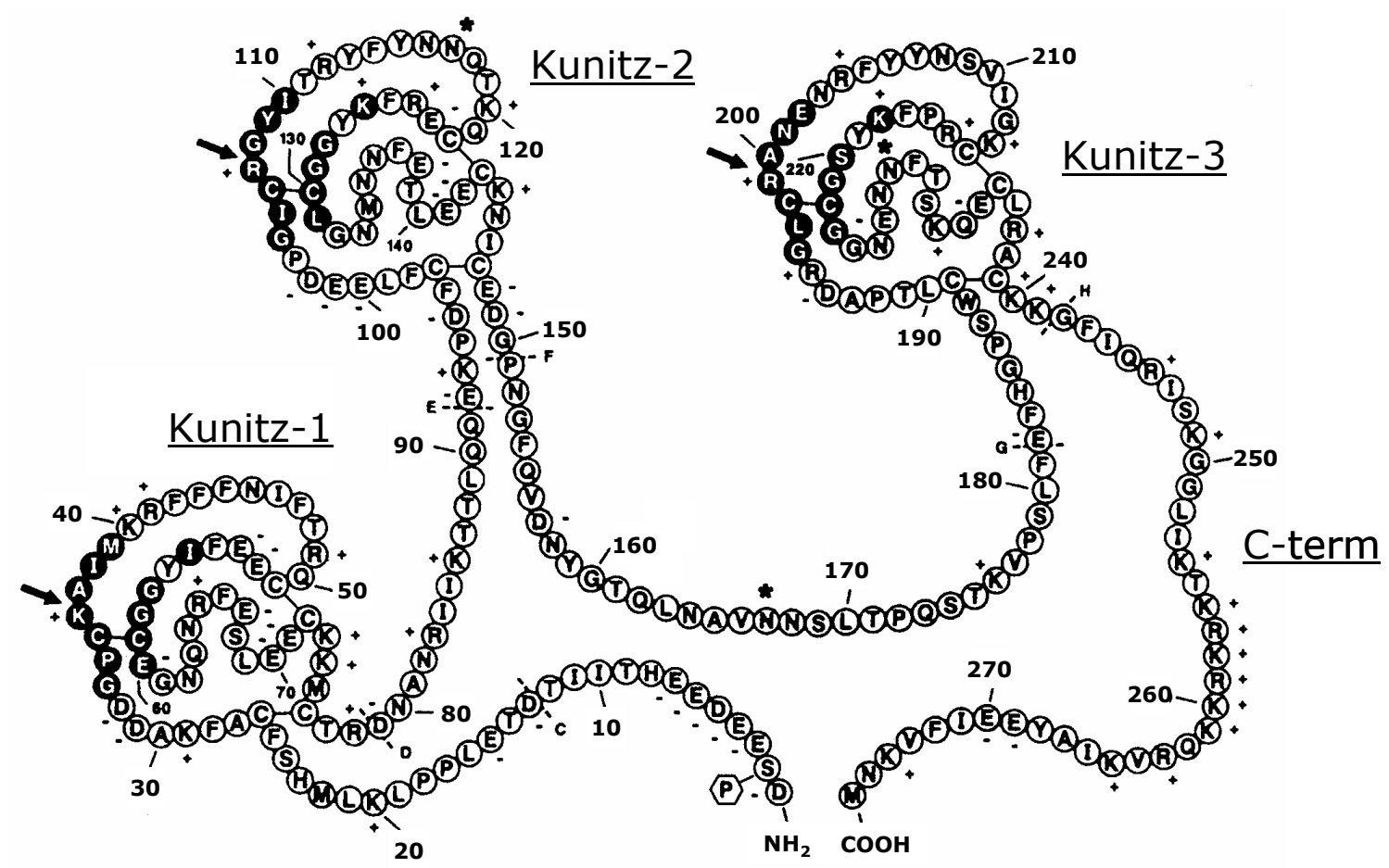

Figure 1.3: Structure of TFPI. Full length TFPI is a Kunitz-type inhibitor of 276 amino acids and consists of $\mathrm{N}$-terminus, three Kunitz domains and a posively charged $\mathrm{C}$-terminus. Each Kunitz domain contains three disulfide bridges and the arrows indicate the location of the presumed P1 residues of the active-site clefts for the Kunitz domains. (Figure taken from Girard TJ et al, Nature, 1989; 338: 518-520).

TFPI in plasma

The majority of TFPI in plasma is produced by and bound (70-80\%) to endothelial cells, which constitutively express the protein ${ }^{179}$. TFPI is also expressed by vascular smooth muscle 
cells, platelets and monocytes ${ }^{180,181}$. Both TFPI $\alpha$ and TFPI $\beta$ are glycophosphatidylinositol (GPI-) linked at the membrane surface, but through different mechanisms. TFPI $\beta$ is directly anchored via a specific C-terminus signal for GPI attachment. In contrast, TFPl $\alpha$ appears to be indirectly GPI-anchored via an unidentified GPI-anchored co-receptor 182-184. Treatment with phosphatidylinositol specific phospholipase C (PI-PLC), which cleaves GPI membrane-anchors, releases approximately $80 \%$ of total surface-TFPI and the remaining $20 \%$ TFPI is released by subsequent heparin treatment ${ }^{176}$. Small amounts of TFPI may associate ionically with the cell surface proteoglycans via its Kunitz 3 domain and basic C-terminus ${ }^{185}$. Plasma TFPI levels are increased 1.5 to 3 -fold after administration of heparin, representing the release of TFPI from endothelial heparan sulfate proteoglycans ${ }^{186,187}$. In addition, TFPl $\alpha$ release is induced by heparin from intracellular stores in vitro ${ }^{188}$.

TFPI secreted by endothelial cells circulates in plasma at a concentration of $\sim 2.5 \mathrm{nM}$ ${ }^{189,190}$. The majority $(70-80 \%)$ of the TFPI plasma pool circulates in association with lipoproteins through disulfide binding with Kunitz-3 ${ }^{191,192}$. Most of the TFPI bound to lipoproteins is associated with low-density lipoproteins (LDL), some with high-density lipoproteins (HDL), and only traces with very low-density lipoproteins (VLDL) ${ }^{191,193}$. TFPI is found in plasma in different molecular forms, the predominant ones being the $34 \mathrm{kDa}$ and $41 \mathrm{kDa}$ forms associated with LDL and HDL, respectively, as well as various truncated forms ${ }^{191,194}$. This size heterogeneity appears, in part, to be the result of C-terminal truncation ${ }^{191}$. Only $10 \%$ of plasma TFPI circulates in a full-length free 43-kDa form. Truncated forms of TPFI lack most of their Cterminal tail and often also most of Kunitz- $3^{195}$. Although it remains to be established how the truncated forms of TFPI are generated physiologically, in vitro data have demonstrated that TFPI is cleaved into truncated forms by various plasma proteases. These include thrombin, plasmin and leukocyte elastase ${ }^{196-198}$. Factor Xa, the natural target for TFPI, also cleaves TFPI, but only when present in molecular excess ${ }^{199}$. Of the total TFPI in blood, between $2 \%$ and $5 \%$ is present within circulating/resting platelets ${ }^{200}$. TFPI is located within intraplatelet stores that can be released upon their full activation ${ }^{200,201}$. 


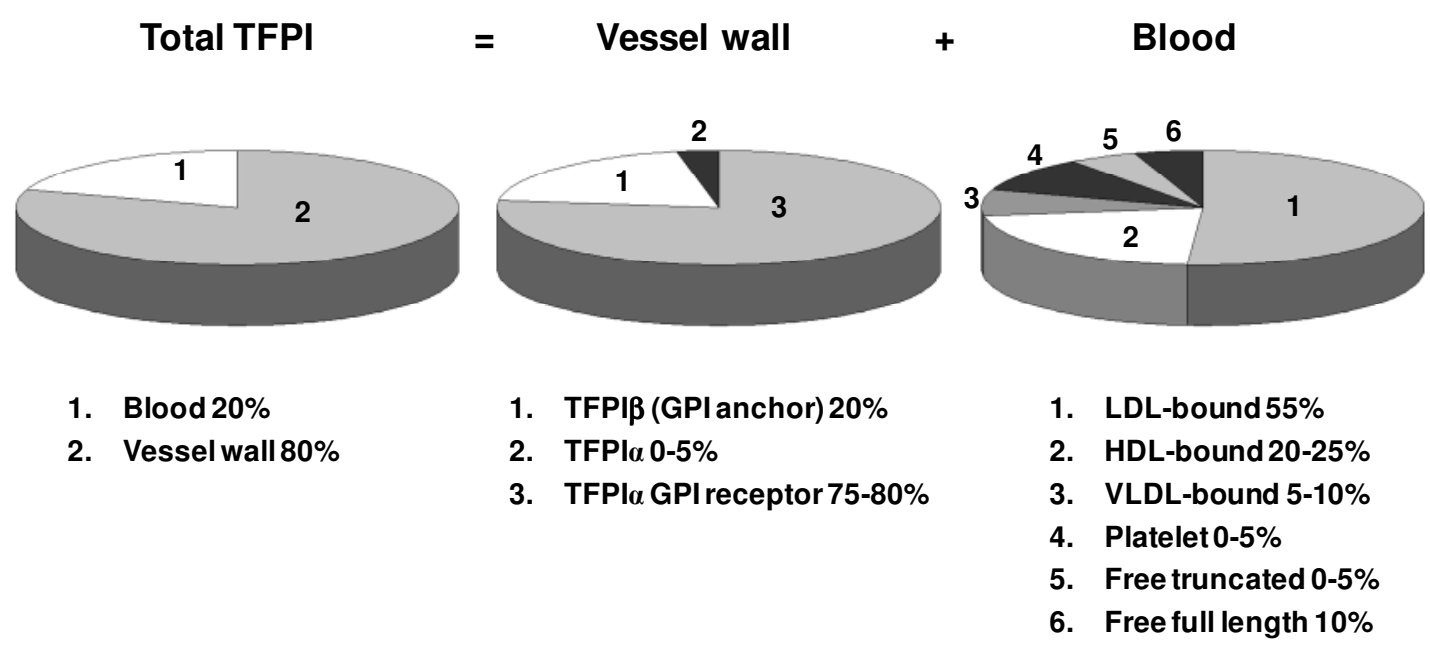

Figure 1.4: Schematic overview of TFPI forms. The majority TFPI is bound to the vessel wall. TFPI $\beta$ $(20 \%)$ is directly anchored via a specific C-terminus signal for GPI attachment. The majority of TFPI $\alpha$ is indirectly GPI-anchored via an unidentified GPI-anchored co-receptor and a small amount of TFPI $\alpha$ is ionically associated with the cell surface proteoglycans. The majority of circulating TFPI is bound to lipoproteins. Most is associated with low-density lipoproteins (LDL), some with high-density lipoproteins (HDL) and traces are associated with very low-density lipoproteins (VLDL). Of total TFPI in blood between $2 \%$ and $5 \%$ is present in platelets. Only $10 \%$ of plasma TFPI circulates in a full length free form, also truncated free TFPI circulates in traces in plasma.

Anti-coagulant function of TFPI

The anticoagulant function of TFPI involves the factor Xa-dependent inhibition of TF/factor VIla. By targeting this serine protease, TFPI directly inhibits the initiation phase of coagulation. This process consists of 2 steps: in the first step factor Xa binds to TFPI and in the second step a quaternary complex is formed between TFPI/factor Xa and TF/factor VIla. Consequently, the amount of factor Xa that escapes inhibition is directly related to the concentration/availability of TF.

Kunitz-2 TFPI binds to factor $X a$ at or near its serine active site ${ }^{31,202}$, and this interaction has a 1:1 stoichiometry and does not require the presence of $\mathrm{Ca}^{2+}$-ions ${ }^{203}$. However, $\mathrm{Ca}^{2+}$-ions augment the potency of factor Xa inhibition by TFPI in the presence of phospholipids surfaces ${ }^{204}$. The C-terminal tail of TFPI is important for interaction with anionic membrane surfaces ${ }^{205-207}$.

The second stage in the inhibition of TF-dependent coagulation involves the binding of the TFPI/factor Xa to TF/factor VIla, resulting in the formation of an inactive (TFPI/factor $\mathrm{Xa} / \mathrm{TF} /$ factor VIla) quaternary complex on the plasma membrane. The Kunitz-1 domain of TFPI interacts with the active site of factor VIla in a $\mathrm{Ca}^{2+}$ dependent manner ${ }^{31,202}$. 
Protein S stimulates the binding and inhibition of factor Xa by TFPI. Recently it has been shown that in a model system using purified components, protein $\mathrm{S}$ increases the affinity of full length TFPI for factor Xa 10 -fold ${ }^{34,208}$. In contrast, protein $S$ was unable to stimulate the interaction between factor Xa and truncated (1-161) TFPI ${ }^{34}$.

Low levels of TFPI have shown to increase the risk of venous thrombosis ${ }^{209,210}$ and several assays have been designed to determine levels and activities of TFPI forms in plasma ${ }^{209,211}$. Commercially available ELISA's are available to measure free TFPI or total TFPI, which also includes lipoprotein bound TFPI ${ }^{209}$. In addition, TFPI activity tests were designed based on chromogenic substrate conversion ${ }^{212,213}$ and on coagulation (clotting assays), which reflect activity of all TFPI forms ${ }^{214,215}$. Truncated TFPI ${ }_{1-161}{ }^{216}$ or TFPI bound to lipoproteins ${ }^{190,217}$ has less anticoagulant activity than free TFPI and Kunitz-3 and the C-terminal tail are necessary for optimal inhibition of factor Xa ${ }^{205,218,219}$.

\section{Protein S deficiency}

Since the anticoagulant activity of APC is dependent on protein $S$, the lack of functional protein $S$ is associated with thrombotic disease ${ }^{220}$. Hereditary deficiency of protein $S$ is a well-established risk factor of familial thrombosis ${ }^{143,221}$. Protein S-deficient patients experience a 5-10 fold higher risk of thrombosis as compared to their normal relatives ${ }^{222}$, the exact risk depends on the severity of the impairment of protein $S$ expression and/or function ${ }^{223}$. Based on protein $\mathrm{S}$ antigen level and APC-cofactor activity, three different types of protein $S$ deficiency have been described: type I is characterized by a reduction in both free and total protein $S^{143,220,221}$, type II by a functional protein defect ${ }^{224,225}$ and type III by a selective deficiency of free protein $\mathrm{S}^{220,226}$. 95\% of protein $\mathrm{S}$ deficient patients show a quantitative deficiency (2/3 type I and 1/3 type III), the remaining $5 \%$ have a functional defect. Since type I and type III often occur together in the same family, they have been suggested to be phenotypic variants of the same genetic defect ${ }^{227,228}$. Pure type III deficiency often cosegregates with the protein S Ser ${ }^{460}$ Pro mutation, known as protein S Heerlen ${ }^{229,230}$.

Protein S Heerlen contains a Ser to Pro substitution at amino acid residue 460, resulting in the loss of the $\mathrm{N}$-linked glycosylation consensus sequence (Asn-Xxx-Ser), and thus $\mathrm{N}$-linked glycosylation at Asn 458. The prevalence of the Ser460Pro mutation among the healthy population was estimated at approximately $0.5 \%$ and it was initially considered a neutral polymorphism ${ }^{229}$. Later it was shown, however, that the Ser460Pro mutation is associated with quantitative protein $\mathrm{S}$ deficiency showing low free protein $\mathrm{S}$ levels ${ }^{230}$. 
Because protein S deficiency is rare, it usually appears partial (heterozygous). Protein $S$ deficiency has been identified in $1-7 \%$ of patients with deep vein thrombosis (DVT) ${ }^{231}$, but the prevalence of heritable protein S deficiency in the general population remains unknown. There is an inter-and intra-individual variation in protein S levels ${ }^{232}$. Levels are related to age, gender, hormonal status and genetic factors ${ }^{231}$. Women have lower protein $\mathrm{S}$ levels than men and in women increasing age has been associated with rising levels of total protein $\mathrm{S}$ antigen 233,234 . Total and free protein $S$ antigen levels decrease during pregnancy ${ }^{226,235}$ and oral contraceptive use ${ }^{236,237}$.

Protein S deficiency is inherited, almost 200 mutations have been characterized in PROS I and approximately $30 \%$ of them have been characterized in vitro, clarifying the mechanisms leading to protein $S$ deficiency ${ }^{238}$. Furthermore, recent studies on the presence of large deletions have increased the number of protein $\mathrm{S}$ deficiencies ${ }^{239,240}$.

\section{AIM OF THIS STUDY}

Protein $S$ is an essential anticoagulant protein that down-regulates thrombin generation via two mechanisms: Protein $\mathrm{S}$ is a cofactor for APC in the inactivation of factor Va and factor VIIIa and protein $\mathrm{S}$ is a cofactor for TFPI in the inhibition of factor Xa. In this study we re-evaluate and validate the cofactor activities of protein $S$ for both anticoagulant proteins APC and TFPI.

The APC-cofactor activity of protein S has been investigated since 1980. Until now, it was generally accepted that only free protein S expressed APC-cofactor activity and that protein S-C4BP has no APC-cofactor activity. The contribution of protein S-C4BP during the inactivation of factor Va and factor Va $a_{\text {Leiden }}$ by APC was investigated in this study (Chapter 2).

With respect to the TFPI-cofactor activity of protein $\mathrm{S}$ there is still limited insight in the mechanism by which TFPI/protein S down-regulates thrombin generation. In a model system, protein $S$ enhances the inhibition of factor Xa by TFPI 10-fold. However, until now, little is known about the in vivo relevance of TFPI-cofactor activity of protein S. The physiological role of the TFPI/protein S system was investigated with thrombin generation-based assays that were developed to determine the activity of this anticoagulant pathway in plasma (Chapter 3 ). The relation between anticoagulant activity of the TFPI/protein S system and plasma levels of TFPI and protein S were investigated in populations of healthy individuals and heterozygous protein S-deficient individuals (Chapter 4) and in women using oral contraceptives (Chapter 5). 


\section{References}

1. Furie B, Furie BC. Molecular and cellular biology of blood coagulation. N Engl J Med. 1992;326:800806.

2. Mann KG, Lorand L. Introduction: blood coagulation. Methods Enzymol. 1993;222:1-10.

3. Davie EW. Biochemical and molecular aspects of the coagulation cascade. Thromb Haemost. 1995;74:1-6.

4. Wilcox JN, Smith KM, Schwartz SM, Gordon D. Localization of tissue factor in the normal vessel wall and in the atherosclerotic plaque. Proc Natl Acad Sci U S A. 1989;86:2839-2843.

5. Butenas S, Mann KG. Blood coagulation. Biochemistry (Mosc). 2002;67:3-12.

6. Mann KG, van't Veer C, Cawthern K, Butenas S. The role of the tissue factor pathway in initiation of coagulation. Blood Coagul Fibrinolysis. 1998;9 Suppl 1:S3-7.

7. Rauch U, Nemerson Y. Tissue factor, the blood, and the arterial wall. Trends Cardiovasc Med. 2000;10:139-143.

8. Morrissey JH. Tissue factor: an enzyme cofactor and a true receptor. Thromb Haemost. 2001;86:66-74.

9. Morrissey JH, Macik BG, Neuenschwander PF, Comp PC. Quantitation of activated factor VII levels in plasma using a tissue factor mutant selectively deficient in promoting factor VII activation. Blood. 1993;81:734-744.

10. Eichinger S, Mannucci PM, Tradati F, Arbini AA, Rosenberg RD, Bauer KA. Determinants of plasma factor VIla levels in humans. Blood. 1995;86:3021-3025.

11. Kirchhofer D, Nemerson Y. Initiation of blood coagulation: the tissue factor/factor VIla complex. Curr Opin Biotechnol. 1996;7:386-391.

12. Hoffman M, Monroe DM, Roberts HR. Cellular interactions in hemostasis. Haemostasis. 1996;26 Suppl 1:12-16.

13. Zwaal RF, Comfurius P, Bevers EM. Lipid-protein interactions in blood coagulation. Biochim Biophys Acta. 1998;1376:433-453.

14. Rosing J, Tans G, Govers-Riemslag JW, Zwaal RF, Hemker HC. The role of phospholipids and factor Va in the prothrombinase complex. J Biol Chem. 1980;255:274-283.

15. Krishnaswamy S, Nesheim ME, Pryzdial EL, Mann KG. Assembly of prothrombinase complex. Methods Enzymol. 1993;222:260-280.

16. Mann KG. Thrombin formation. Chest. 2003;124:4S-10S.

17. Suzuki K, Dahlback B, Stenflo J. Thrombin-catalyzed activation of human coagulation factor V. J Biol Chem. 1982;257:6556-6564.

18. Monkovic DD, Tracy PB. Activation of human factor $\mathrm{V}$ by factor $\mathrm{Xa}$ and thrombin. Biochemistry. 1990;29:1118-1128.

19. Pieters J, Lindhout T, Hemker HC. In situ-generated thrombin is the only enzyme that effectively activates factor VIII and factor V in thromboplastin-activated plasma. Blood. 1989;74:1021-1024. 
20. Gailani D, Broze GJ, Jr. Factor XI activation in a revised model of blood coagulation. Science. 1991;253:909-912.

21. Butenas S, van 't Veer C, Mann KG. Evaluation of the initiation phase of blood coagulation using ultrasensitive assays for serine proteases. J Biol Chem. 1997;272:21527-21533.

22. Sadler JE. Biochemistry and genetics of von Willebrand factor. Annu Rev Biochem. 1998;67:395424.

23. Bailey K, Bettelheim FR, Lorand L, Middlebrook WR. Action of thrombin in the clotting of fibrinogen. Nature. 1951;167:233-234.

24. Mosesson MW. The roles of fibrinogen and fibrin in hemostasis and thrombosis. Semin Hematol. 1992;29:177-188.

25. Lorand L, Konishi K. Activation of the Fibrin Stabilizing Factor of Plasma by Thrombin. Arch Biochem Biophys. 1964;105:58-67.

26. Shen L, Lorand L. Contribution of fibrin stabilization to clot strength. Supplementation of factor XIII-deficient plasma with the purified zymogen. J Clin Invest. 1983;71:1336-1341.

27. Naski MC, Lorand L, Shafer JA. Characterization of the kinetic pathway for fibrin promotion of alpha-thrombin-catalyzed activation of plasma factor XIII. Biochemistry. 1991;30:934-941.

28. Olson ST, Bjork I, Shore JD. Kinetic characterization of heparin-catalyzed and uncatalyzed inhibition of blood coagulation proteinases by antithrombin. Methods Enzymol. 1993;222:525-559.

29. van Boven $\mathrm{HH}$, Lane DA. Antithrombin and its inherited deficiency states. Semin Hematol. 1997;34:188-204.

30. Lindahl U, Kjellen L. Heparin or heparan sulfate--what is the difference? Thromb Haemost. 1991;66:44-48.

31. Girard TJ, Warren LA, Novotny WF, et al. Functional significance of the Kunitz-type inhibitory domains of lipoprotein-associated coagulation inhibitor. Nature. 1989;338:518-520.

32. Broze GJ, Jr. Tissue factor pathway inhibitor. Thromb Haemost. 1995;74:90-93.

33. van 't Veer C, Golden NJ, Kalafatis M, Mann KG. Inhibitory mechanism of the protein C pathway on tissue factor-induced thrombin generation. Synergistic effect in combination with tissue factor pathway inhibitor. J Biol Chem. 1997;272:7983-7994.

34. Hackeng TM, Sere KM, Tans G, Rosing J. Protein S stimulates inhibition of the tissue factor pathway by tissue factor pathway inhibitor. Proc Natl Acad Sci U S A. 2006;103:3106-3111.

35. Huang ZF, Higuchi D, Lasky N, Broze GJ, Jr. Tissue factor pathway inhibitor gene disruption produces intrauterine lethality in mice. Blood. 1997;90:944-951.

36. Dahlback B. The protein C anticoagulant system: inherited defects as basis for venous thrombosis. Thromb Res. 1995;77:1-43.

37. Esmon CT. The protein C pathway. Chest. 2003;124:26S-32S.

38. Dahlback B. Progress in the understanding of the protein C anticoagulant pathway. Int J Hematol. 2004;79:109-116.

39. Solymoss S, Tucker MM, Tracy PB. Kinetics of inactivation of membrane-bound factor Va by activated protein C. Protein S modulates factor Xa protection. J Biol Chem. 1988;263:14884-14890. 
40. Norstrom EA, Tran S, Steen M, Dahlback B. Effects of factor Xa and protein S on the individual activated protein C-mediated cleavages of coagulation factor Va. J Biol Chem. 2006;281:3148631494.

41. Dahlback B. Procoagulant and anticoagulant properties of coagulation factor $\mathrm{V}$ : factor $\mathrm{V}$ Leiden (APC resistance) causes hypercoagulability by dual mechanisms. J Lab Clin Med. 1999;133:415422.

42. Thorelli E, Kaufman RJ, Dahlback B. Cleavage of factor $V$ at Arg 506 by activated protein $C$ and the expression of anticoagulant activity of factor V. Blood. 1999;93:2552-2558.

43. Rosenberg RD. Thrombomodulin gene disruption and mutation in mice. Thromb Haemost. 1997;78:705-709.

44. Jalbert LR, Rosen ED, Moons $L$, et al. Inactivation of the gene for anticoagulant protein $C$ causes lethal perinatal consumptive coagulopathy in mice. J Clin Invest. 1998;102:1481-1488.

45. Mahasandana C, Suvatte V, Marlar RA, Manco-Johnson MJ, Jacobson LJ, Hathaway WE. Neonatal purpura fulminans associated with homozygous protein $\mathrm{S}$ deficiency. Lancet. 1990;335:61-62.

46. DiScipio RG, Davie EW. Characterization of protein S, a gamma-carboxyglutamic acid containing protein from bovine and human plasma. Biochemistry. 1979;18:899-904.

47. Schwarz HP, Heeb MJ, Wencel-Drake JD, Griffin JH. Identification and quantitation of protein S in human platelets. Blood. 1985;66:1452-1455.

48. Fair DS, Marlar RA, Levin EG. Human endothelial cells synthesize protein S. Blood. 1986;67:11681171.

49. Stern D, Brett J, Harris K, Nawroth P. Participation of endothelial cells in the protein C-protein S anticoagulant pathway: the synthesis and release of protein S. J Cell Biol. 1986;102:1971-1978.

50. Ogura M, Tanabe N, Nishioka J, Suzuki K, Saito H. Biosynthesis and secretion of functional protein S by a human megakaryoblastic cell line (MEG-01). Blood. 1987;70:301-306.

51. Dahlback B. Protein S and C4b-binding protein: components involved in the regulation of the protein C anticoagulant system. Thromb Haemost. 1991;66:49-61.

52. Malm J, He XH, Bjartell A, Shen L, Abrahamsson PA, Dahlback B. Vitamin K-dependent protein S in Leydig cells of human testis. Biochem J. 1994;302 ( Pt 3):845-850.

53. Watkins PC, Eddy R, Fukushima Y, et al. The gene for protein S maps near the centromere of human chromosome 3. Blood. 1988;71:238-241.

54. Ploos van Amstel HK, Reitsma PH, Bertina RM. The human protein S locus: identification of the PS alpha gene as a site of liver protein S messenger RNA synthesis. Biochem Biophys Res Commun. 1988;157:1033-1038.

55. Schmidel DK, Tatro AV, Phelps LG, Tomczak JA, Long GL. Organization of the human protein S genes. Biochemistry. 1990;29:7845-7852.

56. Ploos van Amstel HK, Reitsma PH, van der Logt CP, Bertina RM. Intron-exon organization of the active human protein S gene PS alpha and its pseudogene PS beta: duplication and silencing during primate evolution. Biochemistry. 1990;29:7853-7861.

57. Hoskins J, Norman DK, Beckmann RJ, Long GL. Cloning and characterization of human liver cDNA encoding a protein S precursor. Proc Natl Acad Sci U S A. 1987;84:349-353. 
58. Furie B, Furie BC. Molecular basis of vitamin K-dependent gamma-carboxylation. Blood.1990;75:1753-1762.

59. Kaufman RJ. Post-translational modifications required for coagulation factor secretion and function. Thromb Haemost. 1998;79:1068-1079.

60. Dahlback B, Stenflo J. High molecular weight complex in human plasma between vitamin Kdependent protein S and complement component C4b-binding protein. Proc Natl Acad Sci U S A. 1981;78:2512-2516.

61. Griffin JH, Gruber A, Fernandez JA. Reevaluation of total, free, and bound protein S and C4bbinding protein levels in plasma anticoagulated with citrate or hirudin. Blood. 1992;79:3203-3211.

62. Lundwall A, Dackowski W, Cohen $E$, et al. Isolation and sequence of the cDNA for human protein $S$, a regulator of blood coagulation. Proc Natl Acad Sci U S A. 1986;83:6716-6720.

63. Gershagen S, Fernlund P, Lundwall A. A cDNA coding for human sex hormone binding globulin. Homology to vitamin K-dependent protein S. FEBS Lett. 1987;220:129-135.

64. Nelsestuen GL. Interactions of vitamin K-dependent proteins with calcium ions and phospholipid membranes. Fed Proc. 1978;37:2621-2625.

65. Walker FJ. Properties of chemically modified protein S: effect of the conversion of gammacarboxyglutamic acid to gamma-methyleneglutamic acid on functional properties. Biochemistry. 1986;25:6305-6311.

66. Huang $M$, Rigby AC, Morelli $X$, et al. Structural basis of membrane binding by Gla domains of vitamin K-dependent proteins. Nat Struct Biol. 2003;10:751-756.

67. Sunnerhagen M, Forsen S, Hoffren AM, Drakenberg T, Teleman O, Stenflo J. Structure of the $\mathrm{Ca}(2+)$-free Gla domain sheds light on membrane binding of blood coagulation proteins. Nat Struct Biol. 1995;2:504-509.

68. Soriano-Garcia M, Padmanabhan K, de Vos AM, Tulinsky A. The Ca2+ ion and membrane binding structure of the Gla domain of Ca-prothrombin fragment 1. Biochemistry. 1992;31:2554-2566.

69. Grinnell BW, Walls JD, Marks C, et al. Gamma-carboxylated isoforms of recombinant human protein S with different biologic properties. Blood. 1990;76:2546-2554.

70. Rezende SM, Lane DA, Mille-Baker B, Samama MM, Conard J, Simmonds RE. Protein S Gla-domain mutations causing impaired $\mathrm{Ca}(2+)$-induced phospholipid binding and severe functional protein $\mathrm{S}$ deficiency. Blood. 2002;100:2812-2819.

71. Dahlback B. Purification of human vitamin K-dependent protein S and its limited proteolysis by thrombin. Biochem J. 1983;209:837-846.

72. Dahlback B, Lundwall A, Stenflo J. Localization of thrombin cleavage sites in the amino-terminal region of bovine protein S. J Biol Chem. 1986;261:5111-5115.

73. Lu D, Xie RL, Rydzewski A, Long GL. The effect of $\mathrm{N}$-linked glycosylation on molecular weight, thrombin cleavage, and functional activity of human protein S. Thromb Haemost. 1997;77:11561163.

74. Schwalbe RA, Ryan J, Stern DM, Kisiel W, Dahlback B, Nelsestuen GL. Protein structural requirements and properties of membrane binding by gamma-carboxyglutamic acid-containing plasma proteins and peptides. J Biol Chem. 1989;264:20288-20296. 
75. Giri TK, Villoutreix BO, Wallqvist A, Dahlback B, de Frutos PG. Topological studies of the amino terminal modules of vitamin K-dependent protein $\mathrm{S}$ using monoclonal antibody epitope mapping and molecular modeling. Thromb Haemost. 1998;80:798-804.

76. Borgel D, Gaussem P, Garbay C, et al. Implication of protein S thrombin-sensitive region with membrane binding via conformational changes in the gamma-carboxyglutamic acid-rich domain. Biochem J. 2001;360:499-506.

77. Suzuki K, Nishioka J, Hashimoto S. Regulation of activated protein C by thrombin-modified protein S. J Biochem. 1983;94:699-705.

78. Walker FJ. Regulation of vitamin K-dependent protein S. Inactivation by thrombin. J Biol Chem. 1984;259:10335-10339.

79. Long GL, Lu D, Xie RL, Kalafatis M. Human protein S cleavage and inactivation by coagulation factor Xa. J Biol Chem. 1998;273:11521-11526.

80. Morboeuf O, Borgel D, Gaussem P, et al. Characterization of cleaved plasma protein $\mathrm{S}$ with a monoclonal antibody-based assay. Thromb Haemost. 2000;84:604-610.

81. Brinkman HJ, Mertens K, van Mourik JA. Proteolytic cleavage of protein S during the hemostatic response. J Thromb Haemost. 2005;3:2712-2720.

82. Stenflo J. Contributions of Gla and EGF-like domains to the function of vitamin K-dependent coagulation factors. Crit Rev Eukaryot Gene Expr. 1999;9:59-88.

83. Dahlback B, Hildebrand B, Linse S. Novel type of very high affinity calcium-binding sites in betahydroxyasparagine-containing epidermal growth factor-like domains in vitamin K-dependent protein S. J Biol Chem. 1990;265:18481-18489.

84. Stenberg $Y$, Linse S, Drakenberg T, Stenflo J. The high affinity calcium-binding sites in the epidermal growth factor module region of vitamin K-dependent protein S. J Biol Chem. 1997;272:23255-23260.

85. Stenberg Y, Drakenberg T, Dahlback B, Stenflo J. Characterization of recombinant epidermal growth factor (EGF)-like modules from vitamin-K-dependent protein S expressed in Spodoptera cells--the cofactor activity depends on the N-terminal EGF module in human protein S. Eur J Biochem. 1998;251:558-564.

86. Stenberg Y, Muranyi A, Steen C, Thulin E, Drakenberg T, Stenflo J. EGF-like module pair 3-4 in vitamin K-dependent protein S: modulation of calcium affinity of module 4 by module 3 , and interaction with factor X. J Mol Biol. 1999;293:653-665.

87. Persson KE, Stenflo J, Linse S, et al. Binding of calcium to anticoagulant protein S: role of the fourth EGF module. Biochemistry. 2006;45:10682-10689.

88. He X, Shen L, Villoutreix BO, Dahlback B. Amino acid residues in thrombin-sensitive region and first epidermal growth factor domain of vitamin K-dependent protein $\mathrm{S}$ determining specificity of the activated protein C cofactor function. J Biol Chem. 1998;273:27449-27458.

89. Hackeng TM, Yegneswaran S, Johnson AE, Griffin JH. Conformational changes in activated protein $C$ caused by binding of the first epidermal growth factor-like module of protein S. Biochem J. 2000;349 Pt 3:757-764.

90. Mille-Baker B, Rezende SM, Simmonds RE, Mason PJ, Lane DA, Laffan MA. Deletion or replacement of the second EGF-like domain of protein $S$ results in loss of APC cofactor activity. Blood. 2003;101:1416-1418. 
91. Manfioletti G, Brancolini C, Avanzi G, Schneider C. The protein encoded by a growth arrest-specific gene (gas6) is a new member of the vitamin $\mathrm{K}$-dependent proteins related to protein $\mathrm{S}$, a negative coregulator in the blood coagulation cascade. Mol Cell Biol. 1993;13:4976-4985.

92. Villoutreix BO, Garcia de Frutos P, Lovenklev M, Linse S, Fernlund P, Dahlback B. SHBG region of the anticoagulant cofactor protein $\mathrm{S}$ : secondary structure prediction, circular dichroism spectroscopy, and analysis of naturally occurring mutations. Proteins. 1997;29:478-491.

93. Hillarp A, Dahlback B. Novel subunit in C4b-binding protein required for protein $\mathrm{S}$ binding. J Biol Chem. 1988;263:12759-12764.

94. Hillarp A, Hessing $M$, Dahlback B. Protein $S$ binding in relation to the subunit composition of human C4b-binding protein. FEBS Lett. 1989;259:53-56.

95. Webb JH, Villoutreix BO, Dahlback B, Blom AM. Localization of a hydrophobic binding site for anticoagulant protein $\mathrm{S}$ on the beta -chain of complement regulator C4b-binding protein. J Biol Chem. 2001;276:4330-4337.

96. Dahlback B, Smith CA, Muller-Eberhard HJ. Visualization of human C4b-binding protein and its complexes with vitamin K-dependent protein $\mathrm{S}$ and complement protein C4b. Proc Natl Acad Sci U S A. 1983;80:3461-3465.

97. Scharfstein J, Ferreira A, Gigli I, Nussenzweig V. Human C4-binding protein. I. Isolation and characterization. J Exp Med. 1978;148:207-222.

98. Dahlback B, Hildebrand B. Degradation of human complement component C4b in the presence of the C4b-binding protein-protein S complex. Biochem J. 1983;209:857-863.

99. Hillarp A, Dahlback B. Cloning of CDNA coding for the beta chain of human complement component C4b-binding protein: sequence homology with the alpha chain. Proc Natl Acad Sci U S A. 1990;87:1183-1187.

100. Hillarp A, Dahlback B. The protein S-binding site localized to the central core of C4b-binding protein. J Biol Chem. 1987;262:11300-11307.

101. Fernandez JA, Heeb MJ, Griffin JH. Identification of residues $413-433$ of plasma protein $\mathrm{S}$ as essential for binding to C4b-binding protein. J Biol Chem. 1993;268:16788-16794.

102. Fernandez JA, Griffin JH, Chang GT, et al. Involvement of amino acid residues 423-429 of human protein S in binding to C4b-binding protein. Blood Cells Mol Dis. 1998;24:101-112; discussion 113.

103. Hardig $Y$, Rezaie A, Dahlback B. High affinity binding of human vitamin K-dependent protein $S$ to a truncated recombinant beta-chain of C4b-binding protein expressed in Escherichia coli. J Biol Chem. 1993;268:3033-3036.

104. Hardig Y, Dahlback B. The amino-terminal module of the C4b-binding protein beta-chain contains the protein S-binding site. J Biol Chem. 1996;271:20861-20867.

105. van de Poel RH, Meijers JC, Dahlback B, Bouma BN. C4b-binding protein (C4BP) beta-chain Short Consensus Repeat-2 specifically contributes to the interaction of C4BP with protein S. Blood Cells Mol Dis. 1999;25:279-286.

106. Dahlback B. Purification of human C4b-binding protein and formation of its complex with vitamin K-dependent protein S. Biochem J. 1983;209:847-856. 
107. Giri TK, Linse S, Garcia de Frutos P, Yamazaki T, Villoutreix BO, Dahlback B. Structural requirements of anticoagulant protein $\mathrm{S}$ for its binding to the complement regulator $\mathrm{C} 4 \mathrm{~b}$-binding protein. J Biol Chem. 2002;277:15099-15106.

108. Esmon C. The protein C pathway. Crit Care Med. 2000;28:S44-48.

109. Kisiel W. Human plasma protein C: isolation, characterization, and mechanism of activation by alpha-thrombin. J Clin Invest. 1979;64:761-769.

110. Esmon CT, Stenflo J, Suttie JW. A new vitamin K-dependent protein. A phospholipid-binding zymogen of a serine esterase. J Biol Chem. 1976;251:3052-3056.

111. Stenflo J. A new vitamin K-dependent protein. Purification from bovine plasma and preliminary characterization. J Biol Chem. 1976;251:355-363.

112. Gruber A, Griffin JH. Direct detection of activated protein C in blood from human subjects. Blood. 1992;79:2340-2348.

113. Esmon CT, Owen WG. Identification of an endothelial cell cofactor for thrombin-catalyzed activation of protein C. Proc Natl Acad Sci U S A. 1981;78:2249-2252.

114. Stearns-Kurosawa DJ, Kurosawa S, Mollica JS, Ferrell GL, Esmon CT. The endothelial cell protein C receptor augments protein $C$ activation by the thrombin-thrombomodulin complex. Proc Natl Acad Sci U S A. 1996;93:10212-10216.

115. Esmon CT. The endothelial cell protein C receptor. Thromb Haemost. 2000;83:639-643.

116. Taylor FB, Jr., Peer GT, Lockhart MS, Ferrell G, Esmon CT. Endothelial cell protein C receptor plays an important role in protein C activation in vivo. Blood. 2001;97:1685-1688.

117. Rezaie AR. Exosite-dependent regulation of the protein C anticoagulant pathway. Trends Cardiovasc Med. 2003;13:8-15.

118. Suzuki K, Nishioka J, Hashimoto S. Protein C inhibitor. Purification from human plasma and characterization. J Biol Chem. 1983;258:163-168.

119. Heeb MJ, Griffin JH. Physiologic inhibition of human activated protein C by alpha 1-antitrypsin. J Biol Chem. 1988;263:11613-11616.

120. Riewald M, Petrovan RJ, Donner A, Mueller BM, Ruf W. Activation of endothelial cell protease activated receptor 1 by the protein C pathway. Science. 2002;296:1880-1882.

121. Vehar GA, Davie EW. Preparation and properties of bovine factor VIII (antihemophilic factor). Biochemistry. 1980;19:401-410.

122. Marlar RA, Griffin JH. Deficiency of protein C inhibitor in combined factor V/VIII deficiency disease. J Clin Invest. 1980;66:1186-1189.

123. Kisiel W, Canfield WM, Ericsson LH, Davie EW. Anticoagulant properties of bovine plasma protein C following activation by thrombin. Biochemistry. 1977;16:5824-5831.

124. Walker FJ, Sexton PW, Esmon CT. The inhibition of blood coagulation by activated Protein C through the selective inactivation of activated Factor V. Biochim Biophys Acta. 1979;571:333342.

125. Walker FJ. Regulation of activated protein $\mathrm{C}$ by a new protein. A possible function for bovine protein S. J Biol Chem. 1980;255:5521-5524. 
126. Suzuki K, Stenflo J, Dahlback B, Teodorsson B. Inactivation of human coagulation factor $\mathrm{V}$ by activated protein C. J Biol Chem. 1983;258:1914-1920.

127. Kalafatis $M$, Rand MD, Mann KG. The mechanism of inactivation of human factor $V$ and human factor Va by activated protein C. J Biol Chem. 1994;269:31869-31880.

128. Nicolaes GA, Tans G, Thomassen MC, et al. Peptide bond cleavages and loss of functional activity during inactivation of factor $\mathrm{Va}$ and factor VaR506Q by activated protein C. J Biol Chem. 1995;270:21158-21166.

129. Bakker HM, Tans G, Janssen-Claessen T, et al. The effect of phospholipids, calcium ions and protein $\mathrm{S}$ on rate constants of human factor Va inactivation by activated human protein C. Eur J Biochem. 1992;208:171-178.

130. Walker FJ. Regulation of activated protein C by protein S. The role of phospholipid in factor Va inactivation. J Biol Chem. 1981;256:11128-11131.

131. Dahlback B, Carlsson M, Svensson PJ. Familial thrombophilia due to a previously unrecognized mechanism characterized by poor anticoagulant response to activated protein C: prediction of a cofactor to activated protein C. Proc Natl Acad Sci U S A. 1993;90:1004-1008.

132. Bertina RM, Koeleman BP, Koster $\mathrm{T}$, et al. Mutation in blood coagulation factor $\mathrm{V}$ associated with resistance to activated protein C. Nature. 1994;369:64-67.

133. Voorberg J, Roelse J, Koopman R, et al. Association of idiopathic venous thromboembolism with single point-mutation at Arg506 of factor V. Lancet. 1994;343:1535-1536.

134. Greengard JS, Sun X, Xu X, Fernandez JA, Griffin JH, Evatt B. Activated protein C resistance caused by Arg506GIn mutation in factor Va. Lancet. 1994;343:1361-1362.

135. Rosing J, Hoekema L, Nicolaes GA, et al. Effects of protein S and factor Xa on peptide bond cleavages during inactivation of factor Va and factor VaR506Q by activated protein C. J Biol Chem. 1995;270:27852-27858.

136. Norstrom EA, Steen M, Tran S, Dahlback B. Importance of protein S and phospholipid for activated protein C-mediated cleavages in factor Va. J Biol Chem. 2003;278:24904-24911.

137. Nesheim ME, Canfield WM, Kisiel W, Mann KG. Studies of the capacity of factor Xa to protect factor Va from inactivation by activated protein C. J Biol Chem. 1982;257:1443-1447.

138. Hackeng TM, Hessing $M$, van 't Veer $C$, et al. Protein S binding to human endothelial cells is required for expression of cofactor activity for activated protein C. J Biol Chem. 1993;268:39934000 .

139. Villoutreix BO, Teleman O, Dahlback B. A theoretical model for the Gla-TSR-EGF-1 region of the anticoagulant cofactor protein S: from biostructural pathology to species-specific cofactor activity. J Comput Aided Mol Des. 1997;11:293-304.

140. Saller F, Villoutreix BO, Amelot A, et al. The gamma-carboxyglutamic acid domain of anticoagulant protein $S$ is involved in activated protein $C$ cofactor activity, independently of phospholipid binding. Blood. 2005;105:122-130.

141. Yegneswaran S, Wood GM, Esmon CT, Johnson AE. Protein S alters the active site location of activated protein $\mathrm{C}$ above the membrane surface. A fluorescence resonance energy transfer study of topography. J Biol Chem. 1997;272:25013-25021. 
142. Yegneswaran S, Smirnov MD, Safa O, Esmon NL, Esmon CT, Johnson AE. Relocating the active site of activated protein $\mathrm{C}$ eliminates the need for its protein $\mathrm{S}$ cofactor. A fluorescence resonance energy transfer study. J Biol Chem. 1999;274:5462-5468.

143. Bertina RM, van Wijngaarden A, Reinalda-Poot J, Poort SR, Bom VJ. Determination of plasma protein S--the protein cofactor of activated protein C. Thromb Haemost. 1985;53:268-272.

144. Dahlback B. Inhibition of protein Ca cofactor function of human and bovine protein S by C4bbinding protein. J Biol Chem. 1986;261:12022-12027.

145. Nishioka J, Suzuki K. Inhibition of cofactor activity of protein S by a complex of protein S and C4bbinding protein. Evidence for inactive ternary complex formation between protein S, C4b-binding protein, and activated protein C. J Biol Chem. 1990;265:9072-9076.

146. Saposnik B, Borgel D, Aiach M, Gandrille S. Functional properties of the sex-hormone-binding globulin (SHBG)-like domain of the anticoagulant protein S. Eur J Biochem. 2003;270:545-555.

147. van de Poel RH, Meijers JC, Rosing J, Tans G, Bouma BN. C4b-binding protein protects coagulation factor Va from inactivation by activated protein C. Biochemistry. 2000;39:14543- 14548.

148. Fay PJ, Smudzin TM, Walker FJ. Activated protein C-catalyzed inactivation of human factor VIII and factor VIIla. Identification of cleavage sites and correlation of proteolysis with cofactor activity. J Biol Chem. 1991;266:20139-20145.

149. Shen L, Dahlback B. Factor $V$ and protein $S$ as synergistic cofactors to activated protein $C$ in degradation of factor VIIla. J Biol Chem. 1994;269:18735-18738.

150. Varadi K, Rosing J, Tans G, Pabinger I, Keil B, Schwarz HP. Factor V enhances the cofactor function of protein $S$ in the APC-mediated inactivation of factor VIII: influence of the factor VR506Q mutation. Thromb Haemost. 1996;76:208-214.

151. Castoldi E, Brugge JM, Nicolaes GA, Girelli D, Tans G, Rosing J. Impaired APC cofactor activity of factor $\mathrm{V}$ plays a major role in the APC resistance associated with the factor $\mathrm{V}$ Leiden (R506Q) and R2 (H1299R) mutations. Blood. 2004;103:4173-4179.

152. Lu D, Kalafatis M, Mann KG, Long GL. Comparison of activated protein C/protein S-mediated inactivation of human factor VIII and factor V. Blood. 1996;87:4708-4717.

153. Thorelli E, Kaufman RJ, Dahlback B. Cleavage requirements of factor $V$ in tissue-factor induced thrombin generation. Thromb Haemost. 1998;80:92-98.

154. Thorelli E, Kaufman RJ, Dahlback B. The C-terminal region of the factor V B-domain is crucial for the anticoagulant activity of factor V. J Biol Chem. 1998;273:16140-16145.

155. Walker FJ, Chavin SI, Fay PJ. Inactivation of factor VIII by activated protein C and protein S. Arch Biochem Biophys. 1987;252:322-328.

156. Koedam JA, Meijers JC, Sixma JJ, Bouma BN. Inactivation of human factor VIII by activated protein C. Cofactor activity of protein $\mathrm{S}$ and protective effect of von Willebrand factor. J Clin Invest. 1988;82:1236-1243.

157. van de Poel RH, Meijers JC, Bouma BN. C4b-binding protein inhibits the factor V-dependent but not the factor $\mathrm{V}$-independent cofactor activity of protein $\mathrm{S}$ in the activated protein $\mathrm{C}$-mediated inactivation of factor VIIIa. Thromb Haemost. 2001;85:761-765.

158. Mitchell CA, Kelemen SM, Salem HH. The anticoagulant properties of a modified form of protein S. Thromb Haemost. 1988;60:298-304. 
159. Heeb MJ, Mesters RM, Tans G, Rosing J, Griffin JH. Binding of protein S to factor Va associated with inhibition of prothrombinase that is independent of activated protein C. J Biol Chem. 1993;268:2872-2877.

160. Heeb MJ, Rosing J, Bakker HM, Fernandez JA, Tans G, Griffin JH. Protein S binds to and inhibits factor Xa. Proc Natl Acad Sci U S A. 1994;91:2728-2732.

161. Hackeng TM, van 't Veer C, Meijers JC, Bouma BN. Human protein S inhibits prothrombinase complex activity on endothelial cells and platelets via direct interactions with factors $\mathrm{Va}$ and $\mathrm{Xa}$. J Biol Chem. 1994;269:21051-21058.

162. Heeb MJ, Kojima Y, Rosing J, Tans G, Griffin JH. C-terminal residues 621-635 of protein S are essential for binding to factor Va. J Biol Chem. 1999;274:36187-36192.

163. Heeb MJ, Griffin JH. Activated protein C-dependent and -independent anticoagulant activities of protein S have different structural requirements. Blood Cells Mol Dis. 2002;29:190-199.

164. van Wijnen M, Stam JG, van't Veer C, et al. The interaction of protein S with the phospholipid surface is essential for the activated protein C-independent activity of protein S. Thromb Haemost. 1996;76:397-403.

165. van 't Veer C, Butenas S, Golden NJ, Mann KG. Regulation of prothrombinase activity by protein S. Thromb Haemost. 1999;82:80-87.

166. Sere KM, Janssen MP, Willems GM, Tans G, Rosing J, Hackeng TM. Purified protein S contains multimeric forms with increased APC-independent anticoagulant activity. Biochemistry. 2001;40:8852-8860.

167. Sere KM, Willems GM, Rosing J, Hackeng TM. Protein S multimers are generated in vitro and affect protein S structure-function analyses. Semin Hematol. 2006;43:S111-120.

168. Heeb MJ, Schuck P, Xu X. Protein S multimers and monomers each have direct anticoagulant activity. J Thromb Haemost. 2006;4:385-391.

169. van't Veer C, Hackeng TM, Biesbroeck D, Sixma JJ, Bouma BN. Increased prothrombin activation in protein S-deficient plasma under flow conditions on endothelial cell matrix: an independent anticoagulant function of protein S in plasma. Blood. 1995;85:1815-1821.

170. Koenen RR, Tans G, van Oerle R, Hamulyak K, Rosing J, Hackeng TM. The APC-independent anticoagulant activity of protein $\mathrm{S}$ in plasma is decreased by elevated prothrombin levels due to the prothrombin G20210A mutation. Blood. 2003;102:1686-1692.

171. Sere KM, Rosing J, Hackeng TM. Inhibition of thrombin generation by protein $S$ at low procoagulant stimuli: implications for maintenance of the hemostatic balance. Blood. 2004;104:3624-3630.

172. Koenen RR, Christella M, Thomassen LG, Tans G, Rosing J, Hackeng TM. Effect of oral contraceptives on the anticoagulant activity of protein $\mathrm{S}$ in plasma. Thromb Haemost. 2005;93:853-859.

173. Wun TC, Kretzmer KK, Girard TJ, Miletich JP, Broze GJ, Jr. Cloning and characterization of a cDNA coding for the lipoprotein-associated coagulation inhibitor shows that it consists of three tandem Kunitz-type inhibitory domains. J Biol Chem. 1988;263:6001-6004.

174. Girard TJ, Warren LA, Novotny WF, Bejcek BE, Miletich JP, Broze GJ, Jr. Identification of the $1.4 \mathrm{~kb}$ and $4.0 \mathrm{~kb}$ messages for the lipoprotein associated coagulation inhibitor and expression of the encoded protein. Thromb Res. 1989;55:37-50. 
175. Chang JY, Monroe DM, Oliver JA, Roberts HR. TFPIbeta, a second product from the mouse tissue factor pathway inhibitor (TFPI) gene. Thromb Haemost. 1999;81:45-49.

176. Zhang J, Piro O, Lu L, Broze GJ, Jr. Glycosyl phosphatidylinositol anchorage of tissue factor pathway inhibitor. Circulation. 2003;108:623-627.

177. Kisiel W, Sprecher CA, Foster DC. Evidence that a second human tissue factor pathway inhibitor (TFPI-2) and human placental protein 5 are equivalent. Blood. 1994;84:4384-4385.

178. Chand HS, Foster DC, Kisiel W. Structure, function and biology of tissue factor pathway inhibitor-2. Thromb Haemost. 2005;94:1122-1130.

179. Bajaj MS, Kuppuswamy MN, Saito H, Spitzer SG, Bajaj SP. Cultured normal human hepatocytes do not synthesize lipoprotein-associated coagulation inhibitor: evidence that endothelium is the principal site of its synthesis. Proc Natl Acad Sci U S A. 1990;87:8869-8873.

180. Osterud B. Cellular interactions in tissue factor expression by blood monocytes. Blood Coagul Fibrinolysis. 1995;6 Suppl 1:S20-25.

181. Caplice NM, Mueske CS, Kleppe LS, Peterson TE, Broze GJ, Jr., Simari RD. Expression of tissue factor pathway inhibitor in vascular smooth muscle cells and its regulation by growth factors. Circ Res. 1998;83:1264-1270.

182. Sevinsky JR, Rao LV, Ruf W. Ligand-induced protease receptor translocation into caveolae:a mechanism for regulating cell surface proteolysis of the tissue factor-dependent coagulation pathway. J Cell Biol. 1996;133:293-304.

183. Piro O, Broze GJ, Jr. Comparison of cell-surface TFPlalpha and beta. J Thromb Haemost. 2005;3:2677-2683.

184. Maroney SA, Cunningham AC, Ferrel J, et al. A GPI-anchored co-receptor for tissue factor pathway inhibitor controls its intracellular trafficking and cell surface expression. J Thromb Haemost. 2006;4:1114-1124.

185. Narita M, Bu G, Olins GM, et al. Two receptor systems are involved in the plasma clearance of tissue factor pathway inhibitor in vivo. J Biol Chem. 1995;270:24800-24804.

186. Sandset PM, Abildgaard U, Larsen ML. Heparin induces release of extrinsic coagulation pathway inhibitor (EPI). Thromb Res. 1988;50:803-813.

187. Gori AM, Pepe G, Attanasio M, et al. Tissue factor reduction and tissue factor pathway inhibitor release after heparin administration. Thromb Haemost. 1999;81:589-593.

188. Lupu C, Poulsen E, Roquefeuil S, Westmuckett AD, Kakkar VV, Lupu F. Cellular effects of heparin on the production and release of tissue factor pathway inhibitor in human endothelial cells in culture. Arterioscler Thromb Vasc Biol. 1999;19:2251-2262.

189. Novotny WF, Brown SG, Miletich JP, Rader DJ, Broze GJ, Jr. Plasma antigen levels of the lipoprotein-associated coagulation inhibitor in patient samples. Blood. 1991;78:387-393.

190. Lindahl AK, Sandset PM, Abildgaard U. The present status of tissue factor pathway inhibitor. Blood Coagul Fibrinolysis. 1992;3:439-449.

191. Novotny WF, Girard TJ, Miletich JP, Broze GJ, Jr. Purification and characterization of the lipoprotein-associated coagulation inhibitor from human plasma. J Biol Chem. 1989;264:1883218837. 
192. Broze GJ, Jr., Lange GW, Duffin KL, MacPhail L. Heterogeneity of plasma tissue factor pathway inhibitor. Blood Coagul Fibrinolysis. 1994;5:551-559.

193. Hubbard AR, Jennings CA. Inhibition of the tissue factor-factor VII complex: involvement of factor Xa and lipoproteins. Thromb Res. 1987;46:527-537.

194. Warn-Cramer BJ, Maki SL, Zivelin A, Rapaport SI. Partial purification and characterization of extrinsic pathway inhibitor (the factor Xa-dependent plasma inhibitor of factor VIla/tissue factor). Thromb Res. 1987;48:11-22.

195. Novotny WF, Palmier M, Wun TC, Broze GJ, Jr., Miletich JP. Purification and properties of heparinreleasable lipoprotein-associated coagulation inhibitor. Blood. 1991;78:394-400.

196. Higuchi DA, Wun TC, Likert KM, Broze GJ, Jr. The effect of leukocyte elastase on tissue factor pathway inhibitor. Blood. 1992;79:1712-1719.

197. Ohkura N, Enjyoji K, Kamikubo Y, Kato H. A novel degradation pathway of tissue factor pathway inhibitor: incorporation into fibrin clot and degradation by thrombin. Blood. 1997;90:1883-1892.

198. Li A, Wun TC. Proteolysis of tissue factor pathway inhibitor (TFPI) by plasmin: effect on TFPI activity. Thromb Haemost. 1998;80:423-427.

199. Salemink I, Franssen J, Willems GM, et al. Factor Xa cleavage of tissue factor pathway inhibitor is associated with loss of anticoagulant activity. Thromb Haemost. 1998;80:273-280.

200. Novotny WF, Girard TJ, Miletich JP, Broze GJ, Jr. Platelets secrete a coagulation inhibitor functionally and antigenically similar to the lipoprotein associated coagulation inhibitor. Blood. 1988;72:2020-2025.

201. Maroney SA, Haberichter SL, Friese $P$, et al. Active tissue factor pathway inhibitor is expressed on the surface of coated platelets. Blood. 2007;109:1931-1937.

202. Petersen LC, Sprecher CA, Foster DC, Blumberg H, Hamamoto T, Kisiel W. Inhibitory properties of a novel human Kunitz-type protease inhibitor homologous to tissue factor pathway inhibitor. Biochemistry. 1996;35:266-272.

203. Broze GJ, Jr., Warren LA, Novotny WF, Higuchi DA, Girard JJ, Miletich JP. The lipoproteinassociated coagulation inhibitor that inhibits the factor VII-tissue factor complex also inhibits factor Xa: insight into its possible mechanism of action. Blood. 1988;71:335-343.

204. Huang ZF, Wun TC, Broze GJ, Jr. Kinetics of factor Xa inhibition by tissue factor pathway inhibitor. J Biol Chem. 1993;268:26950-26955.

205. Nordfang O, Bjorn SE, Valentin S, et al. The C-terminus of tissue factor pathway inhibitor is essential to its anticoagulant activity. Biochemistry. 1991;30:10371-10376.

206. Wesselschmidt R, Likert K, Girard T, Wun TC, Broze GJ, Jr. Tissue factor pathway inhibitor: the carboxy-terminus is required for optimal inhibition of factor Xa. Blood. 1992;79:2004-2010.

207. Valentin S, Schousboe I. Factor Xa enhances the binding of tissue factor pathway inhibitor to acidic phospholipids. Thromb Haemost. 1996;75:796-800.

208. Ndonwi M, Broze G, Jr. Protein S enhances the tissue factor pathway inhibitor inhibition of factor Xa but not its inhibition of factor VIla-tissue factor. J Thromb Haemost. 2008;6:1044-1046.

209. Dahm A, Van Hylckama Vlieg A, Bendz B, Rosendaal F, Bertina RM, Sandset PM. Low levels of tissue factor pathway inhibitor (TFPI) increase the risk of venous thrombosis. Blood. 2003;101:4387-4392. 
210. Dahm A, Rosendaal FR, Andersen TO, Sandset PM. Tissue factor pathway inhibitor anticoagulant activity: risk for venous thrombosis and effect of hormonal state. Br J Haematol. 2006;132:333338.

211. Ostergaard PB, Beck TC, Orsted $H$, et al. An enzyme linked immunosorption assay for tissue factor pathway inhibitor. Thromb Res. 1997;87:447-459.

212. Bognacki J, Hammelburger J. Functional and immunologic methods for the measurement of human tissue factor pathway inhibitor. Blood Coagul Fibrinolysis. 1995;6 Suppl 1:S65-72.

213. Bendz B, Andersen TO, Sandset PM. A new sensitive chromogenic substrate assay of tissue factor pathway inhibitor type 1. Thromb Res. 2000;97:463-472.

214. Nordfang O, Valentin S, Beck TC, Hedner U. Inhibition of extrinsic pathway inhibitor shortens the coagulation time of normal plasma and of hemophilia plasma. Thromb Haemost. 1991;66:464467.

215. Dahm AE, Andersen TO, Rosendaal F, Sandset PM. A novel anticoagulant activity assay of tissue factor pathway inhibitor I (TFPI). J Thromb Haemost. 2005;3:651-658.

216. Hamamoto T, Yamamoto M, Nordfang O, Petersen JG, Foster DC, Kisiel W. Inhibitory properties of full-length and truncated recombinant tissue factor pathway inhibitor (TFPI). Evidence that the third Kunitz-type domain of TFPI is not essential for the inhibition of factor VIla-tissue factor complexes on cell surfaces. J Biol Chem. 1993;268:8704-8710.

217. Hansen JB, Huseby KR, Huseby NE, Ezban M, Nordoy A. Tissue factor pathway inhibitor in complex with low density lipoprotein isolated from human plasma does not possess anticoagulant function in tissue factor-induced coagulation in vitro. Thromb Res. 1997;85:413-425.

218. Ettelaie C, Adam JM, James NJ, et al. The role of the C-terminal domain in the inhibitory functions of tissue factor pathway inhibitor. FEBS Lett. 1999;463:341-344.

219. Lockett JM, Mast AE. Contribution of regions distal to glycine-160 to the anticoagulant activity of tissue factor pathway inhibitor. Biochemistry. 2002;41:4989-4997.

220. Comp PC, Esmon CT. Recurrent venous thromboembolism in patients with a partial deficiency of protein S. N Engl J Med. 1984;311:1525-1528.

221. Schwarz HP, Fischer M, Hopmeier P, Batard MA, Griffin JH. Plasma protein S deficiency in familial thrombotic disease. Blood. 1984;64:1297-1300.

222. Zoller B, Berntsdotter A, Garcia de Frutos P, Dahlback B. Resistance to activated protein C as an additional genetic risk factor in hereditary deficiency of protein S. Blood. 1995;85:3518-3523.

223. Makris M, Leach M, Beauchamp NJ, et al. Genetic analysis, phenotypic diagnosis, and risk of venous thrombosis in families with inherited deficiencies of protein S. Blood. 2000;95:1935-1941.

224. Mannucci PM, Valsecchi C, Krachmalnicoff A, Faioni EM, Tripodi A. Familial dysfunction of protein S. Thromb Haemost. 1989;62:763-766.

225. Maccaferri M, Legnani C, Preda L, Palareti G. Protein S activity in patients with heredofamilial protein $S$ deficiency and in patients with juvenile venous thrombosis. Results of a functional method. Thromb Res. 1991;64:647-658.

226. Comp PC, Doray D, Patton D, Esmon CT. An abnormal plasma distribution of protein $S$ occurs in functional protein S deficiency. Blood. 1986;67:504-508. 
227. Zöller B, García de Frutos P, Dahlbäck B. Evaluation of the relationship between protein S and C4bbinding protein isoforms in hereditary protein S deficiency demonstrating type I and type III deficiencies to be phenotypic variants of the same genetic disease. Blood. 1995;85:3524-3531.

228. Simmonds RE, Zöller B, Ireland H, et al. Genetic and phenotypic analysis of a large (122member) protein S-deficient kindred provides an explanation for the familial coexistence of type I and type III plasma phenotypes. Blood. 1997;89:4364-4370.

229. Bertina RM, Ploos van Amstel HK, van Wijngaarden A, et al. Heerlen polymorphism of protein $\mathrm{S}$, an immunologic polymorphism due to dimorphism of residue 460. Blood. 1990;76:538-548.

230. Espinosa-Parrilla Y, Morell M, Souto JC, et al. Absence of linkage between type III protein $S$ deficiency and the PROS1 and C4BP genes in families carrying the protein S Heerlen allele. Blood. 1997;89:2799-2806.

231. Dykes AC, Walker ID, McMahon AD, Islam SI, Tait RC. A study of Protein S antigen levels in 3788 healthy volunteers: influence of age, sex and hormone use, and estimate for prevalence of deficiency state. Br J Haematol. 2001;113:636-641.

232. Melzi d'Eril G, Anesi A, Rizzo V, Trotti R. Biological variation in protein C, protein $\mathrm{S}$ and antithrombin concentrations in plasma of healthy subjects. Eur J Clin Chem Clin Biochem. 1997;35:257-260.

233. Gari M, Falkon L, Urrutia T, Vallve C, Borrell M, Fontcuberta J. The influence of low protein $S$ plasma levels in young women, on the definition of normal range. Thromb Res. 1994;73:149-152.

234. Henkens CM, Bom VJ, Van der Schaaf W, et al. Plasma levels of protein S, protein C, and factor X: effects of sex, hormonal state and age. Thromb Haemost. 1995;74:1271-1275.

235. Fernandez JA, Estelles A, Gilabert J, Espana F, Aznar J. Functional and immunologic protein S in normal pregnant women and in full-term newborns. Thromb Haemost. 1989;61:474-478.

236. Tans G, Curvers J, Middeldorp S, et al. A randomized cross-over study on the effects of levonorgestrel- and desogestrel-containing oral contraceptives on the anticoagulant pathways. Thromb Haemost. 2000;84:15-21.

237. Souto JC, Almasy L, Blangero J, et al. Genetic regulation of plasma levels of vitamin K-dependent proteins involved in hematostatis: results from the GAIT Project. Genetic Analysis of Idiopathic Thrombophilia. Thromb Haemost. 2001;85:88-92.

238. García de Frutos P, Fuentes-Prior P, Hurtado B, Sala N. Molecular basis of protein S deficiency. Thromb Haemost. 2007;98:543-556.

239. Johansson AM, Hillarp A, Sall T, Zöller B, Dahlbäck B, Halldén C. Large deletions of the PROS1 gene in a large fraction of mutation-negative patients with protein $\mathrm{S}$ deficiency. Thromb Haemost. 2005;94:951-957.

240. Yin T, Takeshita S, Sato Y, et al. A large deletion of the PROS1 gene in a deep vein thrombosis patient with protein S deficiency. Thromb Haemost. 2007;98:783-789. 




\section{Chapter 2}

Re-evaluation of the role of the protein $\mathrm{S}-\mathrm{C} 4 \mathrm{~b}$ binding protein complex in activated protein C-catalyzed factor Va-inactivation

This research was originally published in blood Lisbeth F. A. Maurissen, M. Christella L. G. D. Thomassen, Gerry A. F. Nicolaes, Björn Dahlbäck, Guido Tans, Jan Rosing, and Tilman M. Hackeng.

Blood. 2008; 111:3034-41 



\section{SUMMARY}

Protein $S$ expresses cofactor activity for activated protein $C$ (APC) by enhancing the APCcatalyzed proteolysis at $\mathrm{R}^{306}$ in factor $\mathrm{Va}$. It is generally accepted that only free protein $\mathrm{S}$ is active, and that complex formation with C4b-binding protein (C4BP) inhibits the APC-cofactor activity of protein S. However, the present study shows that protein S-C4BP expresses APCcofactor activity, and stimulates APC-catalyzed proteolysis at $\mathrm{R}^{306}$ more than 10 -fold, but instead inhibits proteolysis at $\mathrm{R}^{506}$ by APC 3- to 4-fold. Free protein S stimulates APC-catalyzed cleavage at $\mathrm{R}^{306}$ approximately 20 -fold, and has no effect on cleavage at $\mathrm{R}^{506}$. The resulting net effect of protein S-C4BP complex formation on APC-catalyzed factor Va inactivation is a 6 to 8fold reduction in factor $\mathrm{Va}$ inactivation when compared to free protein $\mathrm{S}$, which is not explained by inhibition of APC-cofactor activity of protein $S$ at $R^{306}$, but by generation of a specific inhibitor for APC-catalyzed proteolysis at $\mathrm{R}^{506}$ of factor $\mathrm{Va}$. These results are of interest for carriers of the factor $V_{\text {Leiden }}$ mutation $\left(\mathrm{R}^{506} \mathrm{Q}\right)$, as protein S-C4BP effectively enhances APCcatalyzed factor $\mathrm{Va}\left(\mathrm{R}^{306}\right)$ inactivation in plasma containing factor $\mathrm{V}_{\text {Leiden. }}$. 


\section{INTRODUCTION.}

Protein $\mathrm{S}$ is a vitamin $\mathrm{K}$-dependent glycoprotein of $75 \mathrm{kDa}$ that expresses multiple anticoagulant activities. ${ }^{1}$ Protein S circulates in plasma at a concentration of $350 \mathrm{nM}$ of which $60 \%$ is tightly bound in a non-covalent complex with C4b-binding protein (C4BP). ${ }^{2}$ C4BP is a high molecular weight plasma protein of $570 \mathrm{kDa}$ with a plasma concentration of $200 \mathrm{nM}$. C4BP is a regulator of the classical pathway of the complement system and consists of seven $\alpha$-chains and one $\beta$-chain, which are held together by disulfide bonds in a central core. ${ }^{3}$ The $\beta$ chain of C4BP binds with high affinity to the sex hormone-binding globulin homology region of protein $S$ in a 1:1 stoichiometry. ${ }^{4,5}$

It was reported that only free protein $\mathrm{S}$ functions as a non-enzymatic cofactor for activated protein C (APC) which accelerates APC-catalyzed inactivation of factor Va and factor VIIIa. ${ }^{6-8}$ Protein $S$ also exhibits anticoagulant activity in the absence of APC in that direct interactions between protein $\mathrm{S}$, factor $\mathrm{Va}$, factor $\mathrm{Xa}$, and phospholipids were reported to inhibit prothrombin activation. However, many of these observations were later explained by the presence of in vitro generated protein $\mathrm{S}$ multimers in purified protein $\mathrm{S}$ preparations. ${ }^{9-13}$ More recently, it was reported that protein $\mathrm{S}$ is a cofactor for TFPI in the down regulation of tissue factor activity by stimulating the inhibition of factor Xa by full length TFPI. ${ }^{14}$

Inactivation of factor Va by APC occurs by limited proteolysis in the heavy chain of factor $\mathrm{Va}$ at residues $\mathrm{R}^{306}, \mathrm{R}^{506}$ and $\mathrm{R}^{679} \cdot{ }^{15}$ Factor $\mathrm{Va}$ inactivation by APC proceeds via biphasic reaction; a rapid proteolysis at $\mathrm{R}^{506}$ that results in the formation of an intermediate with partial cofactor activity, followed by a slow proteolysis at $R^{306}$ which leads to full inactivation of factor Va. ${ }^{16}$ Due to its relatively low rate constant, proteolysis at $\mathrm{R}^{679}$ is not considered to be physiologically relevant. Factor $\mathrm{V}_{\text {Leiden }}{ }^{17}$ is characterized by an arginine to glutamine mutation at position 506 and as a result, inactivation of factor $\mathrm{Va}_{\text {Leiden }}$ proceeds exclusively through proteolysis at $\mathrm{R}^{306}{ }^{17,18}$

Optimal proteolysis of factor Va by APC requires the presence of negatively charged phospholipids and the cofactor protein $\mathrm{S} .{ }^{19-21}$ In the presence of protein S, APC-catalyzed proteolysis at $\mathrm{R}^{306}$ of factor $\mathrm{Va}$ and factor $\mathrm{Va}_{\text {Leiden }}$ is enhanced approximately 20 -fold, while the proteolysis at $\mathrm{R}^{506}$ in general is not affected, although a 4-5 fold stimulation of the proteolysis at $\mathrm{R}^{506}$ by APC in the presence of protein $\mathrm{S}$ can be achieved, depending on the experimental design. ${ }^{22,23}$ It was reported that the APC-cofactor activity of protein $S$ is inhibited by proteolysis of the thrombin-sensitive region of protein $\mathrm{S}^{24}$ or by complex formation with C4BP ${ }^{25-27}$. In addition, it was observed that protein $\mathrm{S}$ relocated the active site of phospholipid- 
bound APC to a position above the membrane surface that favors factor Va inactivation, offering a rationale for APC-cofactor activity expression of protein S. ${ }^{28,29}$ More recently, it was shown that C4BP directly inhibits APC-catalyzed inactivation of factor $\mathrm{Va}^{30}$ both in the presence and absence of protein $\mathrm{S}$.

In line with the fact that C4BP in complex with protein S acts as cofactor in APCcatalyzed factor VIIIa inactivation ${ }^{31}$, we demonstrate in the present study that protein S-C4BP enhances APC-catalyzed factor Va inactivation at $\mathrm{R}^{306}$. It was observed that C4BP did not completely inhibit the APC-cofactor activity of protein $\mathrm{S}$ in plasma, whereas polyclonal antibodies against protein S did fully block the APC-cofactor activity of protein $\mathrm{S}$. The absence of inhibition of APC-cofactor activity of protein S by C4BP was most pronounced in plasma containing factor $\mathrm{V}_{\text {Leiden. }}$. More detailed kinetic analysis demonstrated that protein S-C4BP is a cofactor for APC that stimulates APC-catalyzed proteolysis at $\mathrm{R}^{306}$ of factor Va more than 10 fold and inhibits cleavage at $\mathrm{R}^{506} \sim$ 4-fold.

\section{METHODS}

\section{Materials}

Hepes, Tris and ovalbumin were purchased from Sigma, bovine serum albumin from ICN. The chromogenic substrate S2238 was supplied by Chromogenix, Instrumentation Laboratory, Milan, Italy. Fluorogenic substrate I-1140 was from Bachem, Switzerland. 1,2Dioleoyl-sn-glycero-3-phosphocholine (DOPC), 1,2-Dioleoyl-sn-glycero-3-phosphoserine (DOPS) and 1,2-Dioleoyl-sn-glycero-3-phosphoethanolamine (DOPE) were obtained from Avanti Polar Lipids (Alabaster, Alabama, USA). Phospholipids vesicles (20\% DOPS, 20\% DOPE, $60 \%$ DOPC and 10\%DOPS, 90\% DOPC) were prepared as described previously. ${ }^{32}$

Polyclonal antibodies against protein $\mathrm{S}$ were purchased from DAKO (Glostrup, Denmark). Monoclonal antibody 9H10 against C4BP was a kind gift of Prof. B.N. Bouma. Inhibitory antibodies against factor VIII were a kind gift of Baxter (Vienna, Austria). Protein S was purified as described previously ${ }^{13}$. Human normal factor $\mathrm{V}$ and factor $\mathrm{V}_{\text {Leiden }}{ }^{32}$, human prothrombin ${ }^{6}$, bovine factor $\mathrm{Xa}^{33}$ and human $\mathrm{C}^{3} \mathrm{BP}^{34}$ were purified as described. Preparation of recombinant factor $V\left(R^{506} Q / R^{679} Q\right.$ and $\left.R^{306} Q / R^{679} Q\right)$ has been described previously ${ }^{21}$. Activated protein C was obtained from Enzyme Research Laboratories (ERL, South Bend, IN) and tissue factor (TF) was from Dade Innovin (Behring, Germany). Thrombin calibrator was 
from Thrombinoscope BV (Maastricht, The Netherlands). Thrombin was obtained from Kordia Lab Supplies (Leiden, the Netherlands).

Calibrated Automated Thrombin generation (CAT) assay.

The anticoagulant activity of protein S and protein S-C4BP in plasma ( $0.32 \%$ sodium citrate) was measured using thrombin generation assays. In normal pooled plasma and in plasma from a homozygous carrier of the factor $V_{\text {Leiden }}$ mutation, thrombin generation was initiated with $6.8 \mathrm{pM}$ TF, $240 \mu \mathrm{M}$ phospholipid vesicles (20/60/20 DOPS/DOPC/DOPE) and 16 $\mathrm{mM} \mathrm{CaCl}_{2}$ (final concentrations). Thrombin formation was monitored with the fluorogenic substrate I-1140. Prior to initiation of thrombin generation, normal pooled plasma or factor $V_{\text {Leiden }}$ plasma $(80 \mu \mathrm{l})$ was incubated at $37^{\circ} \mathrm{C}$ during $15 \mathrm{~min}$ with or without $10 \mu \mathrm{l}$ of purified C4BP or antibodies against protein S with or without antibodies against factor VIII. In normal plasma, $1.87 \mu \mathrm{M}$ anti-protein S antibodies completely inhibited the APC-cofactor activity of protein S. Thrombin generation was measured in the presence or absence of APC (final concentration $4 \mathrm{nM}$ in normal plasma and $35 \mathrm{nM}$ in factor $\mathrm{V}_{\text {Leiden }}$ plasma, respectively).

Thrombin generation in clotting plasma was monitored by CAT assays, where conversion of the low affinity fluorogenic substrate by thrombin is followed in time in a Fluoroskan Ascent reader (Thermo Labsystems, Helsinki, Finland) with filter sets $390 \mathrm{~nm}$ excitation and $460 \mathrm{~nm}$-emission ${ }^{35}$. Thrombin generation curves and the area-under-the-curve (endogenous thrombin potential, ETP) were calculated using the Thrombinoscope software (Synapse B.V., Maastricht, The Netherlands) ${ }^{35}$.

Normal factor Va and factor Va $a_{\text {Leiden }}$ inactivation in a model system.

Purified human factor $V(100 \mu \mathrm{l} 12 \mathrm{nM})$ in Hepes-buffered saline (HBS: 25 mM Hepes, $\mathrm{pH}$ 7.7, $175 \mathrm{mM} \mathrm{NaCl}$ ) containing $5 \mathrm{mM} \mathrm{CaCl}_{2}$ and $0.5 \% \mathrm{BSA}$ was activated with thrombin (3 $\mathrm{nM}$ ) and after 15 minutes PPACK (3.5 nM) was added. Factor Va (at a final concentration of $1.2 \mathrm{nM})$ was incubated at $37^{\circ}$ in a mixture containing $50 \mu \mathrm{M}$ phospholipids (20/60/20 DOPS/DOPC/DOPE) and $5 \mathrm{mM} \mathrm{CaCl}_{2}$ with or without $200 \mathrm{nM}$ protein $\mathrm{S}$ or $200 \mathrm{nM}$ protein SC4BP. At time zero, APC was added (final concentration $125 \mathrm{pM}$ ) and at different time points samples were taken from the incubation mixture. The factor Va concentration in these aliquots was determined with a prothrombinase-based factor Va assay: $10 \mu \mathrm{l}$ of the inactivation mixture was added to a mixture $(240 \mu \mathrm{l})$ containing $5 \mathrm{nM}$ bovine factor $\mathrm{Xa}, 1 \mu \mathrm{M}$ human prothrombin, $40 \mu \mathrm{M}$ phospholipids (10/90 DOPS/DOPC) and $2.5 \mathrm{mM} \mathrm{CaCl}$. After one minute prothrombin activation was stopped by a 40 -fold dilution in an ice cold buffer 
containing $50 \mathrm{mM}$ Tris- $\mathrm{HCl}, \mathrm{pH} 7.4,175 \mathrm{mM} \mathrm{NaCl}, 20 \mathrm{mM}$ EDTA and $0.5 \%$ ovalbumin. The amount of thrombin formed was quantified using the chromogenic substrate S2238 as described before. ${ }^{36}$ Time courses of factor $V a$ inactivation were fitted to a biphasic exponential equation according to Nicolaes et al. ${ }^{16}$ Protein S-C4BP complex was prepared by incubation of $2 \mu \mathrm{M}$ protein S with $2.2 \mu \mathrm{M}$ C4BP in HBS containing $3 \mathrm{mM} \mathrm{CaCl}_{2}$ for 15 minutes. After 10 -fold dilution in the reaction mixture, a final concentration of $200 \mathrm{nM}$ protein S-C4BP was reached. Confirmation of complex formation was performed after the inactivation experiments using Superose- 6 size-exclusion chromatography.

Size-exclusion chromatography.

$50 \mu \mathrm{l}$ normal plasma or normal plasma with a molar excess of C4BP (450 nM) over free protein $\mathrm{S}$ or $150 \mu \mathrm{l}$ of the factor $\mathrm{Va}$ inactivation mixtures described above were applied to a Superose- 6 size-exclusion chromatography column at a flow rate of $0.25 \mathrm{ml} / \mathrm{min}$ in Hepesbuffered saline (HBS: $25 \mathrm{mM}$ Hepes, $\mathrm{pH}$ 7.7, $175 \mathrm{mM} \mathrm{NaCl}$ ) containing $1 \mathrm{mM} \mathrm{CaCl}$. Fractions $(0.25 \mathrm{ml})$ were collected and immediately diluted $1: 1$ in HBS containing $30 \mathrm{mg} / \mathrm{ml} \mathrm{BSA}$. Protein $\mathrm{S}$ and protein S-C4BP in the eluting fractions were quantified by ELISA.

\section{Protein S and protein S-C4BP ELISA}

Protein S ELISA was performed as described. ${ }^{13}$ Protein S-C4BP in the elution fractions was quantified by ELISA using the following procedure. Microtiter plate wells were coated with capturing monoclonal antibodies $9 \mathrm{H} 10$ against the $\alpha$-chains of C4BP diluted 1/750 in 0.1 $\mathrm{M} \mathrm{Na}_{2} \mathrm{CO}_{3}, \mathrm{pH} 9.0$ at $4^{\circ} \mathrm{C}$ overnight. Wells were washed and blocked with blocking buffer (HBS containing $3 \% \mathrm{BSA}$ and $3 \mathrm{mM} \mathrm{CaCl}_{2}$ ) for $2 \mathrm{~h}$. Column elution fractions were applied at several dilutions in $\mathrm{HBS}$ containing $0.5 \% \mathrm{BSA}$ and $3 \mathrm{mM} \mathrm{CaCl}_{2}$ and left incubating for $1 \mathrm{~h}$. Wells were washed 3 times with washing buffer (HBS containing $3 \mathrm{mM} \mathrm{CaCl} 2$ and $0.03 \%$ Tween-20), followed by incubation with a 1:1000 dilution of horseradish peroxidase (HRP)-conjugated polyclonal antibodies against protein $\mathrm{S}$ for $1 \mathrm{~h}$. After washing of the wells 5 times with washing buffer, detection of bound HRP-labeled antibodies was performed with a HRP-substrate kit (Pierce).

Inactivation of recombinant factor $V a\left(R^{506} Q / R^{679} Q\right.$ and $\left.R^{306} Q / R^{679} Q\right)$.

Recombinant factor V (R506Q/R679Q or R306Q/R679Q) was activated by thrombin (2 $\mathrm{nM}$ ) and after 15 min PPACK was added to a final concentration of $2.5 \mathrm{nM}$. Recombinant 
factor $V a\left(R^{506} Q / R^{679} Q\right.$ or $\left.R^{306} Q / R^{679} Q\right)$ at a final concentration of $20 \mathrm{pM}$ was incubated at $37^{\circ}$ with phospholipids (50 $\mu \mathrm{M}$ 20/60/20 DOPS/DOPC/DOPE), protein S, protein S-C4BP (200 nM) or C4BP (200nM), in HBS containing $5 \mathrm{mM} \mathrm{CaCl}_{2}$ and 0.5\% BSA. At time zero, APC (0.1 nM) was added and samples were taken at different time points. The time course of factor Va inactivation was monitored with the following prothrombinase-based factor Va assay: $115 \mu \mathrm{l}$ inactivation mixture of recombinant factor $\operatorname{Va}\left(R^{506} Q / R^{679} Q\right.$ and $\left.R^{306} Q / R^{679} Q\right)$ was added to 10 $\mu \mathrm{l}$ of a prothrombin/bovine factor Xa mixture yielding final concentrations of $5 \mathrm{nM}$ bovine factor $\mathrm{Xa}$ and $1 \mu \mathrm{M}$ prothrombin or $0.1 \mathrm{nM}$ bovine factor $\mathrm{Xa}$ and $1 \mu \mathrm{M}$ prothrombin, respectively. After one minute prothrombin activation was stopped by a 40 -fold dilution in an ice cold buffer containing $50 \mathrm{mM}$ Tris- $\mathrm{HCl}, \mathrm{pH}$ 7.4, $175 \mathrm{mM} \mathrm{NaCl}, 20 \mathrm{mM}$ EDTA and 0.5\% ovalbumin and the amount of thrombin formed was determined with the chromogenic substrate S2238. ${ }^{36}$ Time courses of factor Va inactivation were fitted as described. ${ }^{16}$ 


\section{RESULTS}

Regulation of APC-cofactor activity of protein S by C4BP.

Homozygous factor $V_{\text {Leiden }}$ plasma was used to study the APC-cofactor activity of protein $\mathrm{S}$ in plasma. Because the possibility of rapid $\mathrm{R}^{506}$-cleavage by APC in factor $\mathrm{V}_{\text {Leiden }}$ was absent, optimal differences in factor Va-inactivation by APC were detected in the absence compared to the presence of protein $S$ due to the 20 -fold enhancement of the slow cleavage at $R^{306}$ by protein $\mathrm{S}^{19-21}$ When coagulation in factor $\mathrm{V}_{\text {Leiden }}$ plasma was initiated with tissue factor, phospholipids and $\mathrm{CaCl}_{2}$, a typical thrombin generation curve was obtained (Fig 2.1). After a lag time representing the clotting time of plasma, thrombin generation was observed before reaching a peak, followed by inactivation of thrombin by the natural anticoagulants antithrombin and $\alpha_{2}$-macroglobulin. The area under the thrombin generation curve, called the endogenous thrombin potential (ETP), was used as a measure for the total amount of thrombin generated during the coagulation process. In factor $\mathrm{V}_{\text {Leiden }}$ plasma the ETP was determined to be $854 \mathrm{nM}$ Ila.min (Fig 2.1A). When APC was present during thrombin generation, the ETP was reduced due to the proteolytic inactivation of factors Va and VIIla by APC and its cofactor protein S (Fig. 2.1A).
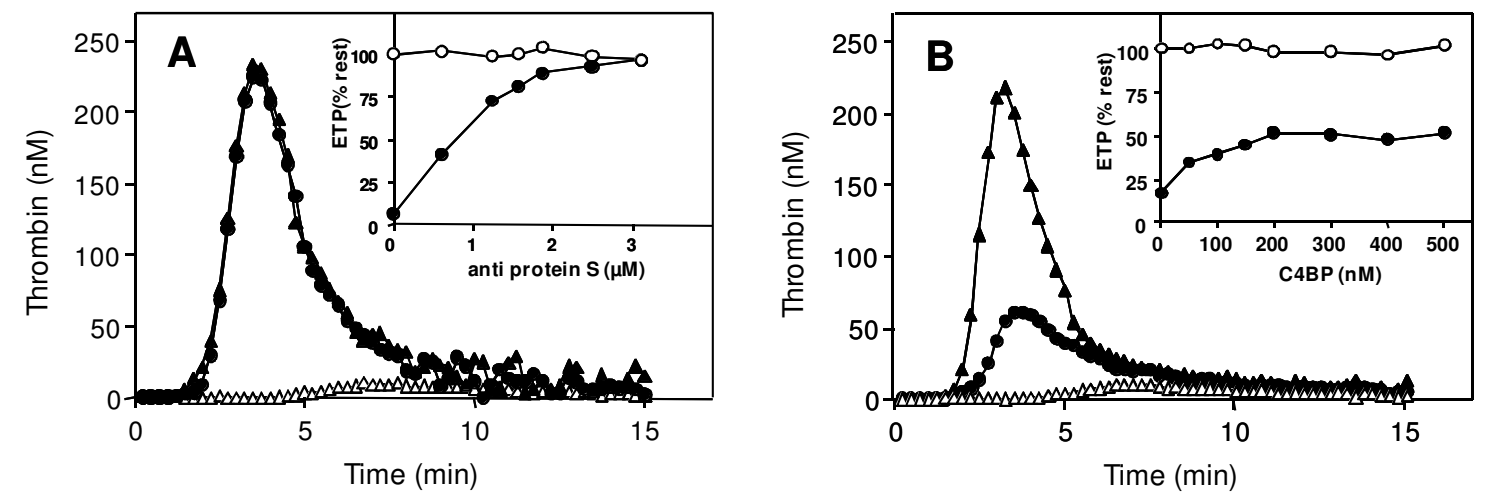

FIGURE 2.1: The effect of C4BP and antibodies against protein $S$ on thrombin generation in plasma with factor $\mathbf{V}_{\text {Leiden }}$ (A): Thrombin generation curves in factor $\mathrm{V}_{\text {Leiden }}$ plasma without $\operatorname{APC}(\mathbf{\Delta})$, with $35 \mathrm{nM} \mathrm{APC}(\triangle)$, and with $35 \mathrm{nM}$ APC with $3.1 \mu \mathrm{M}$ antibodies against protein $\mathrm{S}(\mathbf{O})$.Insets: percentage of endogenous thrombin potential (ETP) as a function of anti-protein $S$ antibody concentration in factor $V_{\text {Leiden }}$ plasma in the absence of APC $(O)$ or in the presence of APC (O). (B): Thrombin generation curves in plasma with factor $V_{\text {Leiden, without }} \operatorname{APC}(\mathbf{\Delta})$, with $\operatorname{APC}(\triangle)$, and with 35 $\mathrm{nM} \mathrm{APC}$ and $500 \mathrm{nM}$ C4BP (O). Insets: percentage of ETP as a function of C4BP concentration in plasma with factor $V_{\text {Leiden }}$ in the absence of APC $(O)$ or in the presence of APC ( 
In these experiments an APC concentration was chosen that resulted in a residual ETP in the presence of APC that was around 10\% (104 nM lla.min) of the ETP determined in the absence of APC (Fig. 2.1).

Addition of antibodies against protein $\mathrm{S}$ in factor $\mathrm{V}_{\text {Leiden }}$ plasma in the presence of APC resulted in a dose-dependent increase of the ETP to a level that was $>95 \%$ of the ETP determined in the absence of APC (Fig. 2.1A, insert). This experiment confirmed that the anticoagulant effect of APC in plasma was for more than 95\% dependent on the presence of its cofactor protein S. ${ }^{37}$

Next, titration experiments were performed with C4BP in plasma from the same factor $V_{\text {Leiden }}$ homozygous individual (Fig. 2.1B). Varying amounts of C4BP were added to factor $V_{\text {Leiden }}$ plasma followed by incubation for 15 min at $37{ }^{\circ} \mathrm{C}$ prior to the initiation of thrombin generation. Titration with C4BP resulted in a dose-dependent increase of the ETP in the presence of APC (Fig 2.1B; insert). However, at the highest concentration of C4BP added (500nM), in the absence of free protein S, APC was still able to reduce the ETP by more than $50 \%$ in the presence of protein S-C4BP (Fig. 1B), which would not have been observed if complex formation with C4BP had inhibited the APC-cofactor activity of protein S. Complex formation of free protein $S$ in plasma with the added C4BP was verified by size-exclusion chromatography (Fig. 2.2). Addition of C4BP to plasma resulted in the complete disappearance of free protein S eluting at $\sim 17 \mathrm{ml}$.
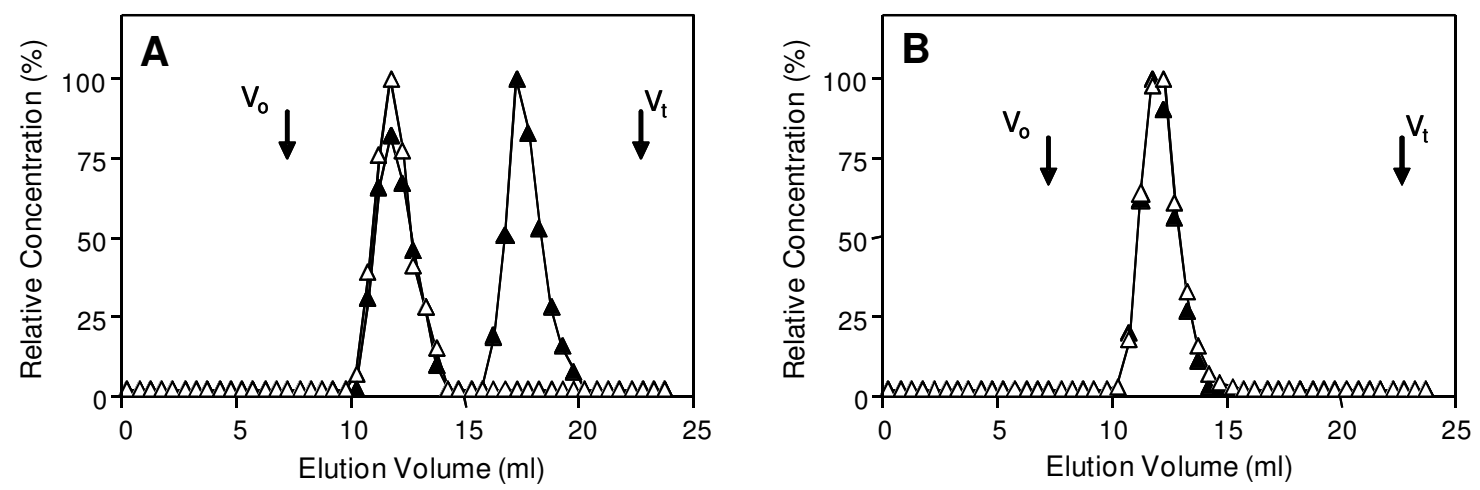

FIGURE 2.2: Verification of plasma protein S-C4BP in factor $\mathbf{V}_{\text {Leiden }}$ plasma by Superose- 6 sizeexclusion chromatography. (A): Superose- 6 size-exclusion chromatography of factor $\mathrm{V}_{\text {Leiden }}$ plasma: protein $S$ was measured with a protein S ELISA $(\mathbf{\Delta})$ and with a protein S-C4BP complex $(\triangle)$ ELISA. (B): Superose-6 size-exclusion chromatography of factor $V_{\text {Leiden }}$ plasma saturated with C4BP: protein $S$ was measured with a protein S ELISA $(\mathbf{\Delta})$ and with a protein S-C4BP complex $(\triangle)$ ELISA. $V_{0}$ : void column volume; $\mathrm{V}_{\mathrm{t}}$ : total column volume. 
Because antibodies against protein $\mathrm{S}$ normalized the ETP of factor $\mathrm{V}_{\text {Leiden }}$ plasma in the presence of APC for more than 95\%, this suggested that antibodies against protein S inhibited the cofactor activity of both free protein $S$ and protein S-C4BP. To demonstrate that the remaining $50 \%$ of the ETP in the presence of APC and excess C4BP (Fig. 2.1B) was due to the cofactor activity of protein S-C4BP for APC, antibodies against protein S were added in the presence of C4BP, which caused the ETP to be restored for more than 95\% compared to the absence of APC (Fig. 2.3A). This indicated that in factor $\mathrm{V}_{\text {Leiden }}$ plasma, the $50 \%$ reduction of the ETP in presence of APC was caused by the APC-cofactor activity of protein S-C4BP complex in factor $\mathrm{Va}_{\text {Leiden }}$ inactivation at $\mathrm{R}^{306}$.
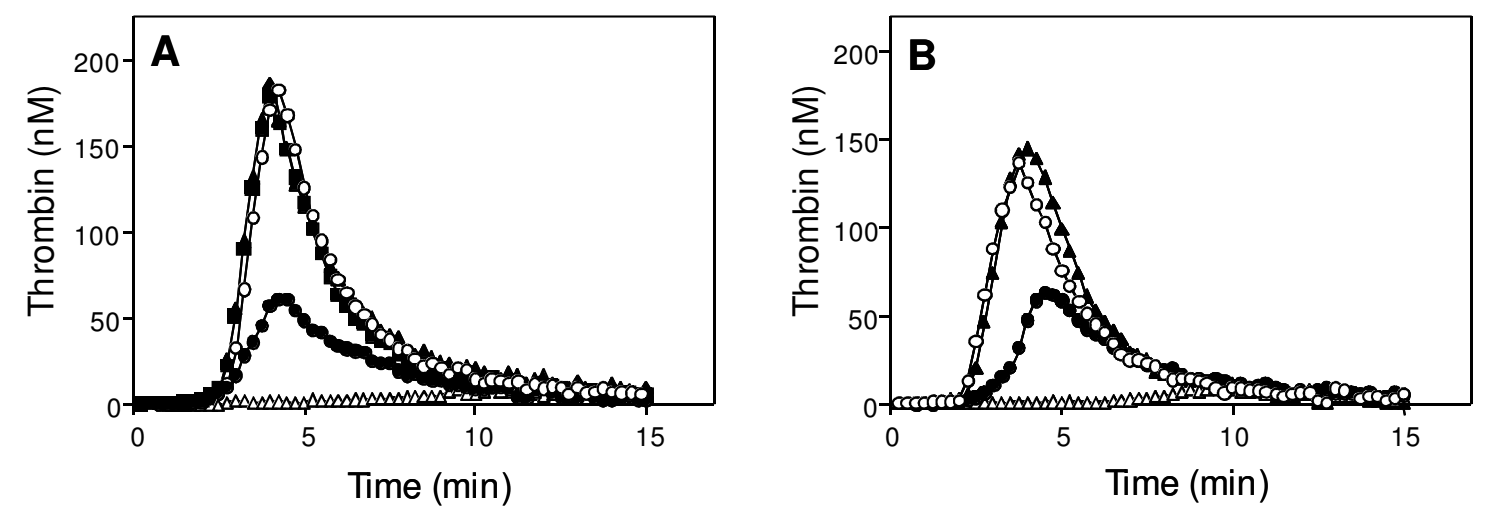

FIGURE 2.3: Effect of protein $S$ and protein S-C4BP on thrombin generation in factor VIIIneutralized plasma factor $\mathbf{V}_{\text {Leiden }}$ plasma. (A): Thrombin generation in factor $\mathrm{V}_{\text {Leiden }}$ plasma was measured without APC $(\mathbf{\Delta})$, with $30 \mathrm{nM} \mathrm{APC}(\triangle)$, with $30 \mathrm{nM} \mathrm{APC}$ and $1.87 \mu \mathrm{M}$ antibodies against protein $\mathrm{S}(\mathrm{O})$ and $30 \mathrm{nM} \mathrm{APC}$ and $500 \mathrm{nM}$ protein S-C4BP $(\bullet)$, and with $30 \mathrm{nM} \mathrm{APC,} 500 \mathrm{nM}$ protein SC4BP, and $1.87 \mu \mathrm{M}$ antibodies against protein $\mathrm{S}(\mathrm{n})$. (B): Thrombin generation in factor VIII-neutralized factor $\mathrm{V}_{\text {Leiden }}$ plasma was measured without $\operatorname{APC}(\mathbf{\Delta})$, with $30 \mathrm{nM} \mathrm{APC}(\triangle)$, with $30 \mathrm{nM} \mathrm{APC}$ and $1.87 \mu \mathrm{M}$ antibodies against protein $\mathrm{S}(\mathrm{O})$ and $30 \mathrm{nM}$ APC and $500 \mathrm{nM}$ protein S-C4BP $(\bullet)$.

Effect of protein S and protein S-C4BP on thrombin generation in factor VIII-neutralized factor $V_{\text {Leiden }}$ plasma

At $6.8 \mathrm{pM}$ TF used in our experiments, the factor VIII(a)-route contributes to thrombin generation, and regulation of thrombin formation by APC might therefore include inactivation of FVIIla. To study the possibility that observed effects were caused by cofactor activity of protein S-C4BP in the APC-catalyzed inactivation of FVIIla ${ }^{31}$, we performed an experiment in factor $\mathrm{V}_{\text {Leiden }}$ plasma to which inhibitory antibodies against factor VIII(a) were added that completely inhibited intrinsically-activated thrombin generation in plasma. In the presence of these antibodies, the effect of protein S-C4BP was studied by adding $500 \mathrm{nM}$ C4BP. As a 
control, factor VIII-neutralized factor $\mathrm{V}_{\text {Leiden }}$ plasma was incubated for 15 minutes with anti protein $\mathrm{S}$ antibodies prior to initiation of thrombin generation in the presence or absence of $30 \mathrm{nM}$ APC (Fig. 2.3B). In factor VIII(a)-neutralized factor $\mathrm{V}_{\text {Leiden }}$ plasma, protein S-C4BP was able to reduce thrombin generation in the presence of APC to a similar extent as in plasma without anti-factor VIIla antibodies, indicating that the observed protein S-C4BP cofactor activity for APC was located at the FVa-inactivation level (Fig. 2.3B).

The differences in inhibition of protein $S$ anticoagulant activity by antibodies against protein $\mathrm{S}$ and by C4BP indicated that the protein S-C4BP complex was active as a cofactor for APC and prompted us to further investigate the reported inhibition of APC-cofactor activity of protein $\mathrm{S}$ by C4BP. ${ }^{25-27}$

\section{APC-catalyzed inactivation of purified factor Va and factor $V a_{\text {Leiden. }}$.}

To characterize the APC-cofactor activity of protein S-C4BP, purified factor $\mathrm{Va}_{\text {Leiden }}$ or normal factor Va was inactivated by APC in the absence or presence of protein S or protein SC4BP in model systems containing purified proteins. In the absence of protein $\mathrm{S}$ or protein $\mathrm{S}$ C4BP, factor $\mathrm{Va}_{\text {Leiden, }}$, which cannot be cleaved at $\mathrm{R}^{506}$, was slowly inactivated by APC via a monophasic inactivation reaction (Fig. 2.4A: open triangles). Addition of protein S or protein SC4BP resulted in an increased rate of inactivation of factor $\mathrm{Va}_{\text {Leiden }}$ which indicated that both protein S and protein S-C4BP stimulated APC-catalyzed proteolysis at $\mathrm{R}^{306}$ (Fig. 2.4A: circles).

In the absence of protein S or protein S-C4BP, inactivation of normal factor Va by APC showed the typical biphasic pattern representing rapid cleavage at $\mathrm{R}^{506}$ yielding a factor $\mathrm{Va}$ intermediate with reduced factor Xa cofactor activity followed by slow cleavage at $\mathrm{R}^{306}$ and complete inactivation of factor $\mathrm{Va}$ (Fig. 2.4B: open triangles). The presence of protein $\mathrm{S}$ as well as protein S-C4BP accelerated factor $V a$ inactivation by APC resulting in an apparent monophasic inactivation curve (Fig. 2.4B). In a control experiment it was observed that C4BP alone had no effect on the inactivation of factor Va by APC (data not shown). Notably, close inspection of the factor Va inactivation curve in the presence of protein S-C4BP complex (Fig 4B, filled circles) shows an enhancement of the second slow phase inactivation of factor Va by APC ( $R^{306}$-cleavage) but an inhibition of the first rapid phase of factor Va inactivation $\left(R^{506}\right.$ cleavage). 

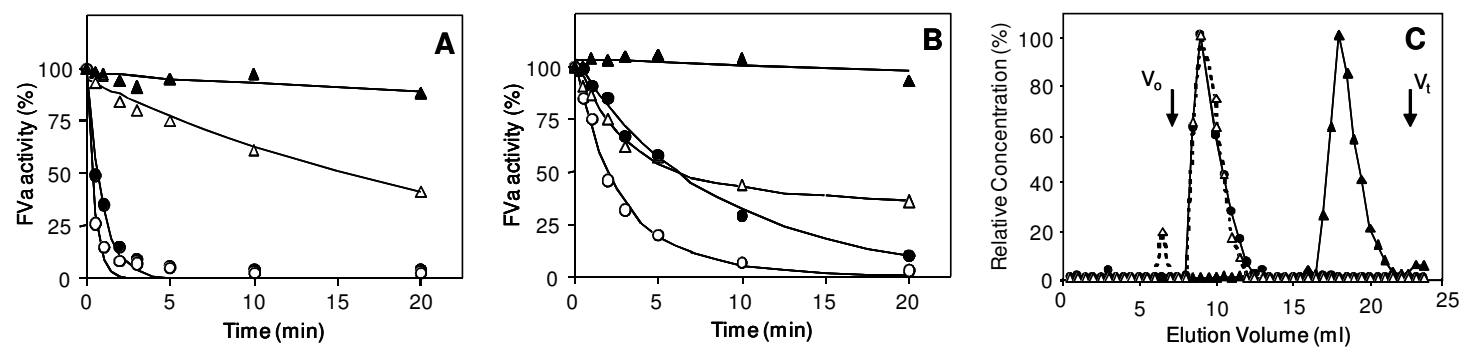

FIGURE 2.4: Effect of protein S and protein S-C4BP on APC-mediated inactivation of factor $\mathrm{Va}$ and factor $\mathrm{Va}_{\text {Leiden }}$ in a reconstituted model system. (A): Inactivation of factor $\mathrm{Va}_{\text {Leiden }}$ by APC $(\triangle), A P C$ and $200 \mathrm{nM}$ protein $\mathrm{S}(O)$ and APC and $200 \mathrm{nM}$ protein S-C4BP $(\bullet)$. Loss of factor Va activity (stability) in the absence of APC (A). (B): Inactivation of factor Va with APC $(\triangle)$ ), with APC and $200 \mathrm{nM}$ protein S (O) and with APC and $200 \mathrm{nM}$ protein S-C4BP $(\mathbf{O})$. Loss of factor Va Leiden activity (stability) in the absence of APC ( $\mathbf{A})$. (C): Superose-6 size-exclusion chromatography of incubation mixtures from B: factor Va, APC and $200 \mathrm{nM}$ protein S: protein S was measured by ELISA ( $\mathbf{\Delta}$ ); factor Va, APC and 200 $\mathrm{nM}$ protein S-C4BP: protein S-C4BP $(\bullet)$ and protein $S(\triangle)$ were measured by ELISA.

To quantitate the effect of protein S-C4BP complex on APC-catalyzed factor Va inactivation, the curves from figure 4 were fitted according to the model proposed by Nicolaes et $\mathrm{al}^{16}$, and the second-order rate constants for cleavage at $\mathrm{R}^{506}$ and $\mathrm{R}^{306}$ obtained in the absence and presence of protein S and protein S-C4BP are presented in Table 2.1. At $200 \mathrm{nM}$ protein S-C4BP complex, an 11-fold stimulation of the APC-catalyzed cleavage at $R^{306}$ was observed. While protein $\mathrm{S}$ had only minor influence on the proteolysis at $\mathrm{R}^{506}$, protein S-C4BP (200 nM) inhibited APC-catalyzed proteolysis at $\mathrm{R}^{506} 3$-4-fold (Table 2.1). In addition, analysis of factor $\mathrm{V}_{\text {Leiden }}$ inactivation revealed a 13-fold stimulation of APC-catalyzed inactivation by protein S-C4BP compared to 26 -fold by protein S.

From these experiments, especially those with purified factor $V a_{\text {Leiden }}$ in which only the cleavage site at $\mathrm{R}^{306}$ is available, we can conclude that protein S-C4BP acts as a cofactor for $A P C$ and that it stimulates APC-catalyzed proteolysis at $\mathrm{R}^{306}$.

To verify that the added protein S-C4BP complex did not dissociate during the time course of factor Va inactivation (Fig. 2.4B) the reaction mixtures remaining at the end of factor Va inactivation were quantitatively subjected to Superose- 6 size-exclusion chromatography and the fractions eluting from the column were tested for the presence of protein $\mathrm{S}$ and protein S-C4BP complex with specific ELISA's (Fig. 2.4C). The reaction mixture containing only free protein $S$ was analyzed by a protein S ELISA and the retention volume of free protein $S$ was approximately $18 \mathrm{ml}$. In the inactivation mixture to which protein S-C4BP complex was added, all protein $\mathrm{S}$ appeared to be associated with C4BP because protein $\mathrm{S}$ and protein $\mathrm{S}$ C4BP co-eluted at a retention volume of $9 \mathrm{ml}$ just after the void volume of the Superose- 6 
column, and no protein S was detected in the subsequent column fractions indicating that the during factor $\mathrm{Va}$ inactivation in the presence of protein S-C4BP, no free protein $\mathrm{S}$ was present (Fig. 2.4C).

Table 2.1: Rate constants of proteolysis at R506 and R306 in plasma factor Va by APC

\begin{tabular}{|l|c|c|c|c|c|}
\hline Normal factor Va & & $\mathbf{k}_{506}\left(\mathrm{~mol}^{-1} \mathbf{~ s e c}^{-1}\right)$ & $\begin{array}{c}\text { Fold- } \\
\text { Stimulation }\end{array}$ & $\mathbf{k}_{306}\left(\mathrm{~mol}^{-1} \mathbf{s e c}^{-1}\right)$ & $\begin{array}{c}\text { Fold- } \\
\text { Stimulation }\end{array}$ \\
\hline APC & 3 & $8.03 \pm 1.50 * 10^{7}$ & - & $3.77 \pm 1.27 * 10^{6}$ & - \\
\hline APC + protein S & 4 & $6.56 \pm 0.44 * 10^{7}$ & 0.82 & $6.76 \pm 0.25 * 10^{7}$ & 18 \\
\hline APC + protein S-C4BP & 4 & $2.31 \pm 0.89 * 10^{7}$ & 0.29 & $4.25 \pm 0.58 * 10^{7}$ & 11 \\
\hline Factor Va Leiden $^{-1}$ & $\mathbf{n}$ & $\mathbf{k}_{506}\left(\mathrm{~mol}^{-1} \mathbf{s e c}^{-1}\right)$ & $\begin{array}{c}\text { Fold- } \\
\text { Stimulation }\end{array}$ & $\mathbf{k}_{306}\left(\mathrm{~mol}^{-1} \mathbf{s e c}^{-1}\right)$ & $\begin{array}{c}\text { Fold- } \\
\text { Stimulation }\end{array}$ \\
\hline APC & 6 & - & - & $2.79 \pm 1.04 * 10^{6}$ & - \\
\hline APC + protein S & 6 & - & - & $7.38 \pm 2.94 * 10^{7}$ & 26 \\
\hline APC + protein S-C4BP & 6 & - & - & $3.62 \pm 1.13 * 10^{7}$ & 13 \\
\hline
\end{tabular}

Concentrations of protein S and protein S-C4BP were $200 \mathrm{nM}$. Rate constants were determined as described. ${ }^{16}$ Data are presented as means \pm S.D.

Inactivation of recombinant factor $V a\left(R^{306} Q / R^{679} Q\right.$ and $\left.R^{506} Q / R^{679} Q\right)$.

Kinetic analysis of inactivation of factor Va by APC in the presence of protein S-C4BP showed that the protein S-C4BP complex inhibited cleavage at $\mathrm{R}^{506}$ in factor Va and stimulated cleavage at $R^{306}$ in factor Va. To confirm the effects of protein S-C4BP on APC-catalyzed proteolysis of $R^{506}$ and $R^{306}$, recombinant factor $\operatorname{Va} R^{306} Q / R^{679} Q$ and factor $V a R^{506} Q / R^{679} Q$, were used in which arginines at positions 306/679 and 506/679 were replaced by glutamines, respectively. These factor Va variants could only be inactivated by APC via cleavage at either $\mathrm{R}^{506}$ (in factor $V a R^{306} \mathrm{Q} / \mathrm{R}^{679} \mathrm{Q}$ ) or $\mathrm{R}^{306}$ (in factor $V_{a} \mathrm{R}^{506} \mathrm{Q} / \mathrm{R}^{679} \mathrm{Q}$ ). The recombinant factor $\mathrm{Va}$ molecules were inactivated by APC in the absence and presence of protein S or protein S-C4BP (Fig. 2.5). Time courses of factor Va inactivation were fitted as described in methods. 

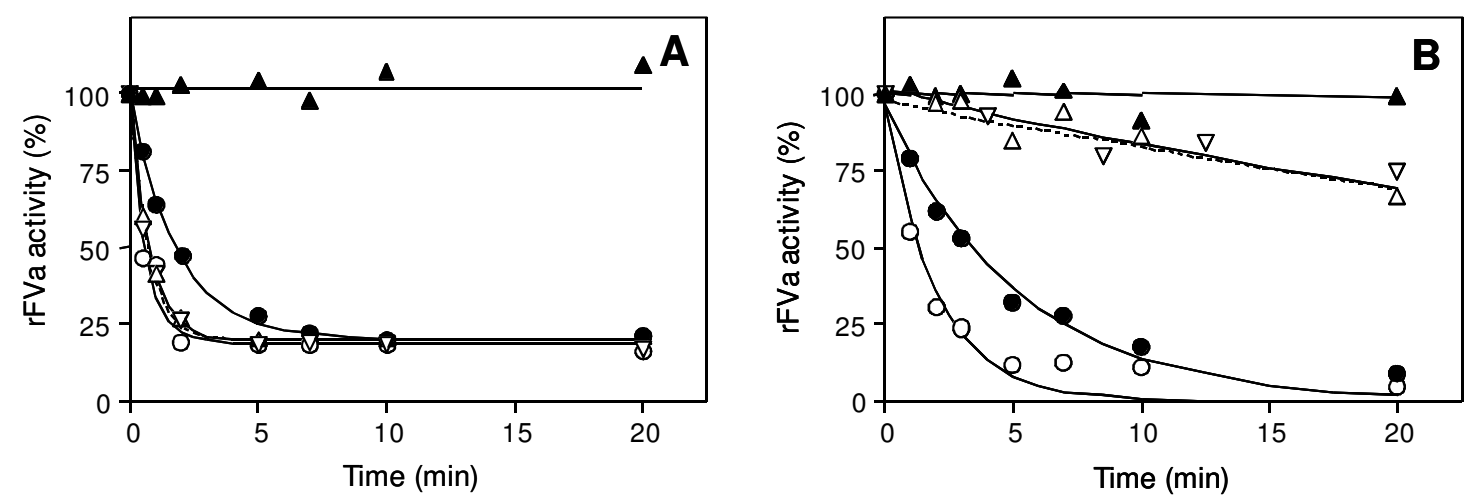

FIGURE 2.5: Effect of protein $S$ and protein S-C4BP on APC-mediated inactivation of recombinant factor Va $\left(R^{306} / R^{679} Q\right.$ and $\left.R^{506} Q / R^{679} Q\right)$ in a reconstituted model system. (A): Inactivation of recombinant factor $V a\left(R^{306} Q / R^{679} Q\right)$ with $A P C(\triangle)$, with APC and $200 \mathrm{nM}$ C4BP $(\nabla$ dashed line) with APC and $200 \mathrm{nM}$ protein $\mathrm{S}(\mathrm{O})$, with APC and $200 \mathrm{nM}$ protein S-C4BP $(O)$ and without APC ( $\mathbf{\Delta})$. (B): Inactivation of recombinant factor Va $\left(R^{506} Q / R^{679} Q\right)$ with APC $(\triangle)$, with APC and $200 \mathrm{nM}$ C4BP ( $\nabla$ dashed line) with APC and $200 \mathrm{nM}$ protein $\mathrm{S}(O)$, with APC and $200 \mathrm{nM}$ protein S-C4BP $(\bullet)$, and without APC ( $\mathbf{\Delta})$.

For $\mathrm{R}^{306} \mathrm{Q} / \mathrm{R}^{679} \mathrm{Q}$ factor Va, protein $\mathrm{S}$ hardly influenced the rate constant of cleavage at $\mathrm{R}^{506}$ (Fig. 2.5A; Table 2.2). ${ }^{21}$ In contrast, the proteolysis at $\mathrm{R}^{506}$ by APC was inhibited 3-fold by protein S-C4BP (Fig. 2.5A; Table 2.2). Experiments performed with recombinant factor $\mathrm{Va}$ $\left(R^{506} Q / R^{679} Q\right)$, in which APC can only cleave the peptide bond at $R^{306}$, showed that protein $S$ and protein S-C4BP stimulated APC-catalyzed proteolysis at $\mathrm{R}^{306} 31$-fold and 14-fold, respectively (Fig. 2.5B; Table 2.2). Addition of C4BP alone to APC had no influence on the inactivation of recombinant factor $V a\left(R^{506} Q / R^{679} Q\right.$ and $\left.R^{306} Q / R^{679} Q\right)$ (Fig. 2.5).

Finally, the effect of C4BP was tested in normal pooled plasma. After initiation of coagulation with tissue factor, the ETP in normal pooled plasma was determined to be $588 \mathrm{nM}$ lla.min. When APC was present during thrombin generation, the ETP was reduced to approximately $10 \%$ of the ETP determined in the absence of APC (51 nM Ila.min). Addition of antibodies against protein S in normal pooled plasma in the presence of APC resulted in a dose-dependent increase of the ETP to a level that was > 95\% of the ETP determined in the absence of APC (data not shown). Addition of C4BP to normal pooled plasma in the presence of APC resulted in a dose-dependent inhibition of APC anticoagulant activity, shown by an increase in ETP in the presence of APC to more than 75\% (452 nM lla.min) compared to the ETP in the absence of APC. (Fig. 2.6: filled circles; insert). However, C4BP was unable to restore the ETP to values that were observed in titrations with polyclonal antibodies against protein S in the presence of APC. 


\section{Chapter 2}

Table 2.2: rate constants of proteolysis at $\mathrm{R}^{306}$ or $\mathrm{R}^{506}$ in recombinant factor Va by APC

\begin{tabular}{|l|c|c|l|c|c|}
\hline $\begin{array}{l}\text { FVa } \\
(\mathbf{R 3 0 6 Q} / \mathbf{R 7 6 9 Q})\end{array}$ & $\begin{array}{c}\mathbf{k}_{506} \\
\left(\mathrm{~mol}^{-1} \mathrm{sec}^{-1}\right)\end{array}$ & $\begin{array}{c}\text { Fold- } \\
\text { stimulation }\end{array}$ & $\begin{array}{l}\text { FVa } \\
(\mathbf{R 5 0 6 Q / R 6 7 9 Q )}\end{array}$ & $\begin{array}{c}\mathbf{k}_{306} \\
\left(\mathrm{~mol}^{-1} \mathrm{sec}^{-1}\right)\end{array}$ & $\begin{array}{c}\text { Fold- } \\
\text { stimulation }\end{array}$ \\
\hline APC & $1.89 * 10^{8}$ & - & APC & $2.41 * 10^{6}$ & - \\
\hline APC + protein S & $2.40 * 10^{8}$ & 1.27 & APC + protein S & $7.58^{*} 10^{7}$ & 31 \\
\hline $\begin{array}{l}\text { APC + protein S- } \\
\text { C4BP }\end{array}$ & $6.72 * 10^{7}$ & 0.36 & $\begin{array}{l}\text { APC + protein S- } \\
\text { C4BP }\end{array}$ & $3.39 * 10^{7}$ & 14 \\
\hline
\end{tabular}

Concentrations of protein S and protein S-C4BP were $200 \mathrm{nM}$. Average rate constants from two separate experiments were determined as described. ${ }^{16}$ 


\section{DISCUSSION}

It has long been accepted that the complex of protein S and C4BP is inactive as a cofactor for APC in the inactivation of factor Va in model systems containing purified proteins or in plasma. ${ }^{26,30}$ In contrast, the data presented in the current paper show that protein SC4BP complex constitutes a cofactor for APC that enhances APC-catalyzed proteolysis at $\mathrm{R}^{306}$ more than 10-fold. In addition, complex formation between protein S and C4BP resulted in the generation of a specific inhibitor of APC-catalyzed cleavage at $\mathrm{R}^{506}$ of factor Va.

These observations offer a rationale for why it was originally concluded that C4BP inhibited the APC-cofactor activity of protein S. The assumption that C4BP inhibited the APCcofactor activity of protein $\mathrm{S}$ could still be supported at first sight by the observation that addition of C4BP to normal plasma reversed the inhibition of thrombin generation by $\mathrm{APC} /$ protein S, apparently by counteracting the APC-cofactor activity of free protein S (Fig. 2.6). However, further observations offer an alternative explanation. Addition of C4BP to plasma still results in factor Va cleavage at $R^{306}$ by APC, but specifically results in inhibition of factor Va cleavage at $R^{506}$ by APC. The inhibition of the fast cleavage at $R^{506}$ by protein S-C4BP and stimulation of the slow cleavage at $\mathrm{R}^{306}$ by protein S-C4BP creates a situation in which the initial rate of factor Va inactivation by APC is decreased (Fig. 2.4B; 2.7).

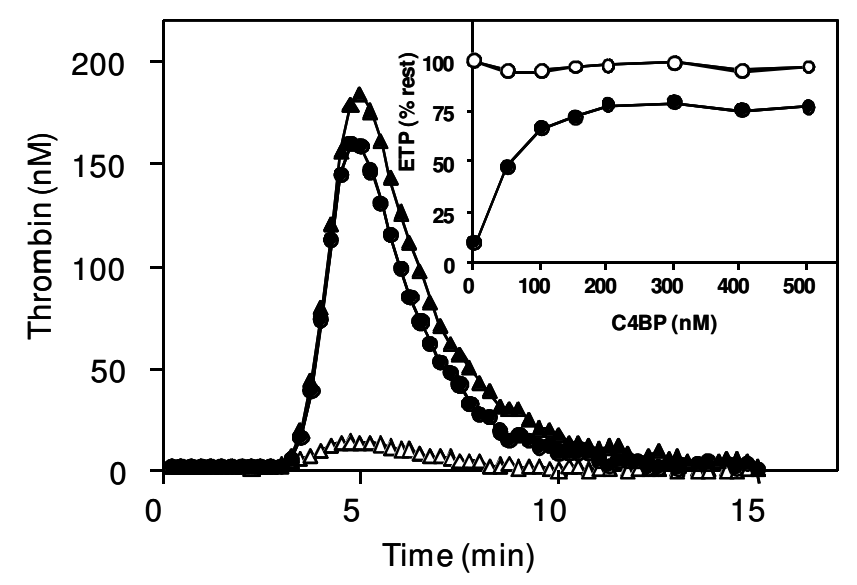

FIGURE 2.6: The effect of C4BP on thrombin generation in normal pooled plasma. Thrombin generation curves in normal pooled plasma without $\operatorname{APC}(\mathbf{\Delta})$, with $4 \mathrm{nM} \mathrm{APC}(\triangle)$, and with $4 \mathrm{nM} \mathrm{APC}$ and $500 \mathrm{nM}$ C4BP $(\Theta)$. Inset: percentage of ETP as a function of C4BP concentration in normal pooled plasma in the absence of APC $(O)$ or in the presence of APC $(\mathbf{O})$.

When factor VIII in plasma was neutralized by inhibitory antibodies, the APC-cofactor activity of protein S-C4BP remained, identifying APC-catalyzed factor Va-inactivation at $\mathrm{R}^{306}$ as the target for the anticoagulant activity of the protein S-C4BP complex. 
It should be realized that differences between previous findings and new data can be explained by different experimental conditions under which experiments were performed. Original findings were done using APTT based clotting-assay to study the effect of protein S and protein S-C4BP on thrombin generation. APTT clotting times correspond to the lag times of CAT assay thrombin generation curves, on top of which the CAT assay allows interpretation of coagulation processes beyond initial clot formation. It is possible that the fast cleavage of factor $V a$ at $\mathrm{R}^{506}$ might play a role in the initial phase of thrombin generation i.e. clot formation, whereas cleavage at $\mathrm{R}^{306}$ might be important after clot formation. In this case, inhibition of APC-catalyzed cleavage at $\mathrm{R}^{506}$ by protein S-C4BP might be responsible for the observed inhibitory activity of C4BP added to plasma in clotting assays.

In a previous study it was suggested that C4BP alone protects factor Va from inactivation by APC. ${ }^{30}$ However, the conditions of these experiments were different from our experimental conditions. Especially the low phospholipid concentrations used in the study might have contributed to the observed protective effect of C4BP- $\alpha$ and C4BP- $\beta$ in factor Vainactivation by APC. It has been proposed that for binding of coagulation proteins of $\sim 75 \mathrm{kDa}$ to phospholipid vesicles (20/80 PS/PC), approximately $1 \%$ of total phospholipid concentration represents the available protein binding sites (ratio protein/PL $=1.0 \mathrm{w} / \mathrm{w}$ ). ${ }^{38}$ In the mentioned study, a phospholipid concentration of $5 \mu \mathrm{M}$ PS/PC was used, which will result in a concentration of total protein binding sites of $50 \mathrm{nM}$ for $75 \mathrm{kDa}$ proteins. If C4BP (570 kDa) binds to phospholipids, even less binding sites will be available, and concentrations of $200 \mathrm{nM}$ C4BP and more could easily inhibit phospholipid-dependent reactions in general, in the present case caused by competition for phospholipid binding sites with factor Va and APC. It was reported that C4BP can bind to phospholipid surfaces through protein $\mathrm{S}^{39-41}$, but also in the absence of protein $S^{40}$. Using ellipsometry studies ${ }^{13}$, we also have observed that C4BP alone is able to bind to 20/80 PS/PC phospholipid vesicles (unpublished results). Taken together, we propose that the use of low phospholipid concentration will promote nonspecific inhibition of phospholipid surface-dependent enzymatic processes, which might offer an explanation for the fact that in the previous report inhibition of APC-catalyzed factor Vainactivation at low phospholipid concentrations was not observed in an activated partial thromboplastin time-based plasma clotting assay (at high phospholipid concentrations). ${ }^{30,42}$

The size of C4BP might contribute to inhibition of proteolysis at $R^{506}$ by APC. Protein $S$ is a cofactor for APC-catalyzed inactivation of factor $V a$ and it reportedly causes a translocation of the active site of APC by binding to APC near the $\mathrm{R}^{506}$ site of factor Va, which has been proposed to optimize factor Va-inactivation. ${ }^{28,43}$ If binding of C4BP to protein $S$ does 
not alter the binding properties of protein S-C4BP to factor Va, it might result in hindrance of the docking of APC to the $\mathrm{FVa}$ /protein S/C4BP complex, resulting in less effective proteolysis at $\mathrm{R}^{506}$ by $\mathrm{APC}$. In line with this, it has been reported previously that interaction between APC and $F V a$ around $R^{506}$ is different from that around $R^{306}$, with the interaction at $R^{506}$ requiring more pronounced molecular contacts between APC and factor Va than the interaction at $R^{306}$. ${ }^{44}$ Covering of these molecular contact sites at $\mathrm{R}^{506}$ by protein S-C4BP might well offer a rationale for the observed inhibition of APC-catalyzed factor Va-inactivation by protein SC4BP.

We propose that protein S-C4BP is a cofactor for APC that, although at a 2 -fold lower activity than free protein $S$, stimulates proteolytic inactivation of factor $V a$ at $R^{306}$ more than 10-fold. In contrast, protein S-C4BP specifically inhibits proteolysis at $\mathrm{R}^{506}$ by APC, most likely explained by interfering with $\mathrm{R}^{506}$ susceptibility for APC by C4BP. However, the net effect of C4BP on protein S-enhanced APC-catalyzed factor Va-inactivation will be a 2-fold inhibition of $\mathrm{R}^{306}$ cleavage, and a 3- to 4-fold inhibition of $\mathrm{R}^{506}$ cleavage, resulting in an overall 6- to 8-fold inhibition of factor Va inactivation by APC (Fig. 2.7).

These results are of interest for carriers of the factor $V_{\text {Leiden }}$ mutation, the most common inherited risk factor for venous thrombosis, in which factor $\mathrm{V}$ is characterized by a $\mathrm{R}^{506}$ to $\mathrm{Q}$ replacement. ${ }^{17,45}$ In this case, an inhibitory effect of protein S-C4BP on APC-cleavage at amino acid position 506 is absent, and especially in the case of homozygotes, effective concentrations protein $\mathrm{S}$ will be closer to that of total protein $\mathrm{S}$ concentrations instead of established free protein $\mathrm{S}$ concentrations.

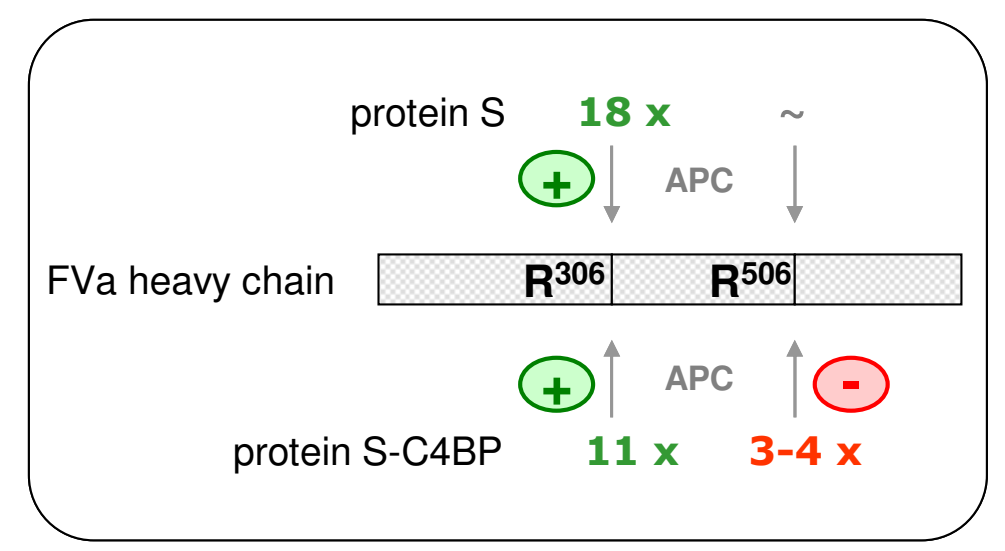

FIGURE 2.7: Effects of protein $S$ and protein S-C4BP on APC-mediated proteolysis of factor Va at $\mathbf{R}^{306}$ and $\mathbf{R}^{506}$. Both protein $S$ and protein S-C4BP are cofactors for APC that stimulate APCmediated proteolysis at $\mathrm{R}^{306}$ in factor $\mathrm{Va} 18$-fold and 11 -fold, respectively. While protein $\mathrm{S}$ has no effect on APC-mediated inactivation at $\mathrm{R}^{506}$ in factor Va, the protein S-C4BP complex specifically inhibits APCmediated cleavage at $\mathrm{R}^{506} 3$-4-fold. 
In conclusion, our observations indicate that C4BP cannot be simply be considered as an inhibitor of APC-cofactor activity of protein $\mathrm{S}$ anymore. The reason that free protein $\mathrm{S}$ is a better cofactor for APC than protein S-C4BP lies in the fact that protein S-C4BP selectively impairs proteolysis at $R^{506}$ by $A P C$, and not by inhibition of the protein S-dependent enhancement of APC-catalyzed proteolysis at $\mathrm{R}^{306}$. The selective impairment of APC-catalyzed proteolysis at $\mathrm{R}^{506}$ by protein $\mathrm{S}$-C4BP will be the main reason for the observed effects of addition of C4BP to plasma. This suggests an active role for the protein S-C4BP complex in the regulation of thrombin formation, which is in concert with an observation in which protein SC4BP is active as a cofactor for TFPI in the regulation of tissue factor activity. ${ }^{14}$ 


\section{REFERENCES}

1. DiScipio RG, Davie EW. Characterization of protein $\mathrm{S}$, a gamma-carboxyglutamic acid containing protein from bovine and human plasma. Biochemistry. 1979;18:899-904.

2. Dahlback B, Stenflo J. High molecular weight complex in human plasma between vitamin Kdependent protein S and complement component C4b-binding protein. Proc Natl Acad Sci U S A. 1981;78:2512-2516.

3. Scharfstein J, Ferreira A, Gigli I, Nussenzweig V. Human C4-binding protein. I. Isolation and characterization. J Exp Med. 1978;148:207-222.

4. Hillarp A, Dahlback B. The protein S-binding site localized to the central core of C4b-binding protein. J Biol Chem. 1987;262:11300-11307.

5. Fernandez JA, Heeb MJ, Griffin JH. Identification of residues 413-433 of plasma protein $\mathrm{S}$ as essential for binding to C4b-binding protein. J Biol Chem. 1993;268:16788-16794.

6. Koedam JA, Meijers JC, Sixma JJ, Bouma BN. Inactivation of human factor VIII by activated protein C. Cofactor activity of protein S and protective effect of von Willebrand factor. J Clin Invest. 1988;82:1236-1243.

7. Shen L, Dahlback B. Factor $V$ and protein $S$ as synergistic cofactors to activated protein $C$ in degradation of factor VIIla. J Biol Chem. 1994;269:18735-18738.

8. Walker FJ. Regulation of activated protein C by a new protein. A possible function for bovine protein S. J Biol Chem. 1980;255:5521-5524.

9. Heeb MJ, Mesters RM, Tans G, Rosing J, Griffin JH. Binding of protein S to factor Va associated with inhibition of prothrombinase that is independent of activated protein C. J Biol Chem. 1993;268:2872-2877.

10. Heeb MJ, Rosing J, Bakker HM, Fernandez JA, Tans G, Griffin JH. Protein S binds to and inhibits factor Xa. Proc Natl Acad Sci U S A. 1994;91:2728-2732.

11. Hackeng TM, van 't Veer C, Meijers JC, Bouma BN. Human protein S inhibits prothrombinase complex activity on endothelial cells and platelets via direct interactions with factors $\mathrm{Va}$ and Xa. J Biol Chem. 1994;269:21051-21058.

12. Heeb MJ, Kojima Y, Rosing J, Tans G, Griffin JH. C-terminal residues 621-635 of protein S are essential for binding to factor Va. J Biol Chem. 1999;274:36187-36192.

13. Sere KM, Janssen MP, Willems GM, Tans G, Rosing J, Hackeng TM. Purified protein S contains multimeric forms with increased APC-independent anticoagulant activity. Biochemistry. 2001;40:8852-8860.

14. Hackeng TM, Sere KM, Tans G, Rosing J. Protein S stimulates inhibition of the tissue factor pathway by tissue factor pathway inhibitor. Proc Natl Acad Sci U S A. 2006;103:3106-3111.

15. Kalafatis $M$, Rand MD, Mann KG. The mechanism of inactivation of human factor $V$ and human factor Va by activated protein C. J Biol Chem. 1994;269:31869-31880.

16. Nicolaes GA, Tans G, Thomassen MC, et al. Peptide bond cleavages and loss of functional activity during inactivation of factor Va and factor VaR506Q by activated protein C. J Biol Chem. 1995;270:21158-21166. 
17. Bertina RM, Koeleman BP, Koster $\mathrm{T}$, et al. Mutation in blood coagulation factor $\mathrm{V}$ associated with resistance to activated protein C. Nature. 1994;369:64-67.

18. Kalafatis M, Bertina RM, Rand MD, Mann KG. Characterization of the molecular defect in factor VR506Q. J Biol Chem. 1995;270:4053-4057.

19. Suzuki K, Stenflo J, Dahlback B, Teodorsson B. Inactivation of human coagulation factor $\mathrm{V}$ by activated protein C. J Biol Chem. 1983;258:1914-1920.

20. Solymoss S, Tucker MM, Tracy PB. Kinetics of inactivation of membrane-bound factor Va by activated protein C. Protein S modulates factor Xa protection. J Biol Chem. 1988;263:14884-14890.

21. Rosing J, Hoekema L, Nicolaes GA, et al. Effects of protein S and factor Xa on peptide bond cleavages during inactivation of factor Va and factor VaR506Q by activated protein C. J Biol Chem. 1995;270:27852-27858.

22. Norstrom EA, Steen M, Tran S, Dahlback B. Importance of protein S and phospholipid for activated protein C-mediated cleavages in factor Va. J Biol Chem. 2003;278:24904-24911.

23. Norstrom EA, Tran S, Steen M, Dahlback B. Effects of factor Xa and protein $S$ on the individual activated protein C-mediated cleavages of coagulation factor Va. J Biol Chem. 2006;281:3148631494.

24. Dahlback B, Lundwall A, Stenflo J. Localization of thrombin cleavage sites in the amino-terminal region of bovine protein S. J Biol Chem. 1986;261:5111-5115.

25. Bertina RM, van Wijngaarden A, Reinalda-Poot J, Poort SR, Bom VJ. Determination of plasma protein S--the protein cofactor of activated protein C. Thromb Haemost. 1985;53:268-272.

26. Dahlback B. Inhibition of protein Ca cofactor function of human and bovine protein S by $\mathrm{C} 4 \mathrm{~b}$ binding protein. J Biol Chem. 1986;261:12022-12027.

27. Nishioka J, Suzuki K. Inhibition of cofactor activity of protein S by a complex of protein S and C4bbinding protein. Evidence for inactive ternary complex formation between protein S, C4b-binding protein, and activated protein C. J Biol Chem. 1990;265:9072-9076.

28. Yegneswaran S, Smirnov MD, Safa O, Esmon NL, Esmon CT, Johnson AE. Relocating the active site of activated protein $\mathrm{C}$ eliminates the need for its protein $\mathrm{S}$ cofactor. A fluorescence resonance energy transfer study. J Biol Chem. 1999;274:5462-5468.

29. Hackeng TM, Yegneswaran S, Johnson AE, Griffin JH. Conformational changes in activated protein $\mathrm{C}$ caused by binding of the first epidermal growth factor-like module of protein S. Biochem J. 2000;349 Pt 3:757-764.

30. van de Poel RH, Meijers JC, Rosing J, Tans G, Bouma BN. C4b-binding protein protects coagulation factor Va from inactivation by activated protein C. Biochemistry. 2000;39:14543-14548.

31. van de Poel RH, Meijers JC, Bouma BN. C4b-binding protein inhibits the factor V-dependent but not the factor $\mathrm{V}$-independent cofactor activity of protein $\mathrm{S}$ in the activated protein $\mathrm{C}$-mediated inactivation of factor VIIla. Thromb Haemost. 2001;85:761-765.

32. Rosing J, Bakker HM, Thomassen MC, Hemker HC, Tans G. Characterization of two forms of human factor Va with different cofactor activities. J Biol Chem. 1993;268:21130-21136.

33. Fujikawa K, Legaz ME, Davie EW. Bovine factors X 1 and X 2 (Stuart factor). Isolation and characterization. Biochemistry. 1972;11:4882-4891. 
34. Koenen RR, Tans G, van Oerle R, Hamulyak K, Rosing J, Hackeng TM. The APC-independent anticoagulant activity of protein $\mathrm{S}$ in plasma is decreased by elevated prothrombin levels due to the prothrombin G20210A mutation. Blood. 2003;102:1686-1692.

35. Hemker HC, Wielders S, Kessels $\mathrm{H}$, Beguin S. Continuous registration of thrombin generation in plasma, its use for the determination of the thrombin potential. Thromb Haemost. 1993;70:617624.

36. Rosing J, Tans G, Govers-Riemslag JW, Zwaal RF, Hemker HC. The role of phospholipids and factor $\mathrm{Va}$ in the prothrombinase complex. J Biol Chem. 1980;255:274-283.

37. Sere KM, Rosing J, Hackeng TM. Inhibition of thrombin generation by protein $S$ at low procoagulant stimuli: implications for maintenance of the hemostatic balance. Blood. 2004;104:3624-3630.

38. Nelsestuen GL, Broderius $\mathrm{M}$. Interaction of prothrombin and blood-clotting factor $\mathrm{X}$ with membranes of varying composition. Biochemistry. 1977;16:4172-4177.

39. Kask L, Trouw LA, Dahlback B, Blom AM. The C4b-binding protein-protein S complex inhibits the phagocytosis of apoptotic cells. J Biol Chem. 2004;279:23869-23873.

40. Schwalbe R, Dahlback B, Hillarp A, Nelsestuen G. Assembly of protein S and C4b-binding protein on membranes. J Biol Chem. 1990;265:16074-16081.

41. Trouw LA, Nilsson SC, Goncalves I, Landberg G, Blom AM. C4b-binding protein binds to necrotic cells and DNA, limiting DNA release and inhibiting complement activation. J Exp Med. 2005;201:1937-1948.

42. van de Poel RH, Meijers JC, Bouma BN. Interaction between protein $\mathrm{S}$ and complement C4bbinding protein (C4BP). Affinity studies using chimeras containing c4bp beta-chain short consensus repeats. J Biol Chem. 1999;274:15144-15150.

43. Heeb MJ, Kojima Y, Hackeng TM, Griffin JH. Binding sites for blood coagulation factor Xa and protein S involving residues 493-506 in factor Va. Protein Sci. 1996;5:1883-1889.

44. Nicolaes GA, Sorensen KW, Friedrich U, et al. Altered inactivation pathway of factor Va by activated protein $C$ in the presence of heparin. Eur J Biochem. 2004;271:2724-2736.

45. Rosendaal FR. Risk factors for venous thrombotic disease. Thromb Haemost. 1999;82:610-619. 



\section{Chapter 3}

A thrombin generation-based assay for measurement of the activity of the TFPI-protein S pathway in plasma; TFPI activity is decreased in heterozygous Type-I protein S-deficient individuals.

In preparation

Lisbeth F.A. Maurissen, Elisabetta Castoldi, Paolo Simioni, Jan Rosing, Tilman M. Hackeng 



\section{SUMMARY}

Background: Protein S has recently been shown to act as a cofactor for full-length tissue factor pathway inhibitor (TFPI) in the down-regulation of thrombin formation. Objectives: To develop a functional test to measure the activity of the TFPI/protein S system in plasma. Methods/Patients: Using calibrated automated thrombography we quantified the activity of the TFPI/protein S system in plasma by measuring thrombin generation in the absence and presence of neutralizing antibodies against protein S or TFPI. The assay performance was examined in 85 normal individuals and in 35 members of protein S-deficient families. Results: The ratio of thrombin peaks determined in the absence and presence of anti-protein $S$ antibodies (protein S-ratio $=0.5$ in normal plasma) is a measure of the TFPI-cofactor activity of protein $\mathrm{S}$. The ratio of the thrombin peaks determined in the absence and presence of antiTFPI antibodies (TFPI-ratio $=0.25$ in normal plasma) is a measure of the overall activity of the TFPI/protein S system. Protein S- and TFPI-ratios were markedly elevated in protein Sdeficient individuals, indicating impairment of the TFPI/protein S system. Both ratios correlated well with full-length TFPI levels determined by a newly developed ELISA, which were significantly lower in protein $\mathrm{S}$ deficient patients $(67 \mathrm{U} / \mathrm{dl})$ than in normal family members $(104 \mathrm{U} / \mathrm{dl})$. Correlation with protein S levels was only apparent in the protein $\mathrm{S}$ deficient individuals. Conclusions: With newly developed functional assays for the TFPI/protein S system we have shown that, due to the combined reduction of protein $\mathrm{S}$ and TFPI levels, the TFPI/protein S anticoagulant pathway is impaired in patients with heterozygous Type-I protein S deficiency. This impairment might contribute to the increased risk of venous thrombosis associated with protein $\mathrm{S}$ deficiency. 


\section{INTRODUCTION}

Protein S, a vitamin $\mathrm{K}$-dependent protein $(75 \mathrm{kDa})$ that circulates in plasma at a concentration of $350 \mathrm{nM}^{1}$, down-regulates blood coagulation by multiple mechanisms. Protein $S$ is a cofactor for activated protein C (APC) which accelerates APC-mediated inactivation of factor $\mathrm{Va}$ and factor VIIIa ${ }^{2,3}$. Protein $\mathrm{S}$ also exhibits APC-independent anticoagulant activity ${ }^{4-8}$, which was recently explained by its ability to stimulate the inactivation of factor Xa (FXa) by tissue factor pathway inhibitor (TFPI) ${ }^{9,10}$.

TFPI is a Kunitz-type inhibitor that circulates in plasma at a concentration of $2.5 \mathrm{nM}^{11}$. The majority of plasma TFPI is truncated and circulates bound to lipoproteins with a reduced anticoagulant activity. Only $10 \%$ of total TFPI circulates free in a full-length $43-k D a$ form ${ }^{12,13}$. TFPI binds to and inhibits FXa through its Kunitz-2 domain and subsequently inhibits factor $\mathrm{VIla/tissue} \mathrm{factor} \mathrm{(TF)} \mathrm{by} \mathrm{forming} \mathrm{an} \mathrm{inactive} \mathrm{FXa/TFPI/TF/FVIla} \mathrm{quaternary} \mathrm{complex} \mathrm{through}$ its Kunitz-1 domain ${ }^{14}$. Protein S stimulates TFPI by enhancing the TFPI/FXa interaction 10-fold 9

Protein S deficiency ${ }^{15}$ and low levels of TFPI ${ }^{16}$ are risk factors for venous thrombosis. However, it is not known whether the TFPI-cofactor activity of protein S plays a role in the risk of venous thrombosis of protein S-deficient individuals. Therefore, we have designed thrombin generation-based tests to measure the TFPI-cofactor activity of protein $\mathrm{S}$ and the overall activity of the TFPI/protein S system in plasma. These assays, which rely on the increase in thrombin generation after addition of antibodies against protein S or TFPI, were validated in plasma of healthy and protein S-deficient individuals.

\section{MATERIALS AND METHODS}

\section{Plasma samples}

Normal pooled plasma in $3.8 \%$ sodium citrate was obtained from George King Biomedical (Overland Park, Kansas, USA). Normal pooled plasma in 3.2\% sodium citrate was prepared in house by pooling plasma from 98 healthy volunteers.

Plasma samples were collected in $3.2 \%$ sodium citrate from 85 healthy hospital employees from the University Hospital Maastricht. Blood was centrifuged at 2000g for 15 min to separate plasma from blood cells and again at $11000 \mathrm{~g}$ for $5 \mathrm{~min}$ to obtain platelet-poor plasma ${ }^{17}$. Moreover, 18 individuals with partial type-I protein S deficiency (total protein $\mathrm{S}$ 
levels $<70 \%$, free protein $S$ levels $<65 \%$ ) belonging to 10 unrelated families were recruited at Padua Academic Hospital. Seventeen relatives without protein S deficiency acted as controls. $7 / 18$ protein S-deficient individuals and 2/17 normal individuals had experienced venous thrombosis. Blood was collected in $3.8 \%$ sodium citrate and centrifuged at $2000 \mathrm{~g}$ for $10 \mathrm{~min}$ to obtain platelet-poor plasma.

Thrombin generation-based assays for the measurement of the activity of the TFPI/protein S system

Thrombin generation was determined with the Calibrated Automated Thrombogram (CAT) method in a total reaction volume of $120 \mu \mathrm{l}$. Plasma (68 $\mu \mathrm{l}$ ) was incubated during 15 minutes at $37{ }^{\circ} \mathrm{C}$ with $4 \mu \mathrm{l}$ corn trypsin inhibitor (CTI, Haematologic Technologies, Essex Junction VT, USA, $33 \mu \mathrm{g} / \mathrm{ml}$ final concentration) and with $8 \mu \mathrm{l}$ of either $\mathrm{HN}$ buffer (no antibodies) or polyclonal antibodies against protein S (2.80 $\mu \mathrm{M}$, Zebra Bioscience, Enschede, the Netherlands) or monoclonal antibodies against TFPI (0.66 $\mu \mathrm{M}, \mathrm{MW} 1848$, Sanquin, Amsterdam, the Netherlands). Coagulation was initiated with $20 \mu \mathrm{l}$ of a 7:1 mixture of the PPP low and PPP 5 pM reagents (Thrombinoscope B.V., Maastricht, the Netherlands), yielding final concentrations of $\sim 1.5 \mathrm{pM}$ TF and $4 \mu \mathrm{M}$ phospholipids in the assay mixture. These concentrations are optimal for the detection of the activity of the TFPI/protein S system. After addition of a mixture $(20 \mu \mathrm{l})$ of $\mathrm{CaCl}_{2}$ and fluorogenic substrate (I-1140, Bachem, Bubendorf, Switzerland) yielding final concentrations of $16 \mathrm{mM}$ and $300 \mu \mathrm{M}$, respectively, substrate conversion by thrombin was followed in a Fluoroskan Ascent reader (Thermo Labsystems, Helsinki, Finland) with $390 \mathrm{~nm}$-excitation and $460 \mathrm{~nm}$-emission filter sets. Peak heights of thrombin generation were calculated using software obtained from Thrombinoscope B.V., Maastricht, The Netherlands ${ }^{18}$. The ratio of thrombin peaks determined in the absence and presence of either anti-protein S antibodies (protein S-ratio) or anti-TFPI antibodies (TFPIratio) was a measure of the TFPI-cofactor activity of protein $S$ or the total TFPI/protein $S$ activity, respectively.

\section{Determination of factor levels in plasma}

Protein S ELISAs were performed as described ${ }^{6,19}$ using normal pooled plasma as a standard. Total and free protein $S$ antigen levels were expressed as $U / d l$, assuming that $1 \mathrm{dl}$ normal pooled plasma contains $100 \mathrm{U}$ total or free protein $\mathrm{S}$. 
Plasma free TFPI levels were measured with a commercial ELISA kit (Asserachrom Free TFPI, Diagnostica Stago, Asnières, France). TFPI activity was determined by the Actichrom TFPI activity assay (American Diagnostica, Stamford CT, USA).

\section{Full-length TFPI ELISA}

Set-up

Microtiter plate wells were coated overnight at $4{ }^{\circ} \mathrm{C}$ with $50 \mu \mathrm{l}$ of a solution containing $2 \mu \mathrm{g} / \mathrm{ml}$ of a monoclonal antibody against the C-terminal region of TFPI (MW1848, Sanquin) in $0.1 \mathrm{M} \mathrm{Na}_{2} \mathrm{CO}_{3}, \mathrm{pH}$ 9.0. Further steps were performed at room temperature. After coating, the wells were blocked for 2 hours with $200 \mu$ of blocking buffer consisting of Hepes buffered saline (HBS: $25 \mathrm{mM}$ Hepes, $\mathrm{pH}$ 7.9, $175 \mathrm{mM} \mathrm{NaCl}$ ) with $30 \mathrm{mg} / \mathrm{ml}$ BSA. Plasma samples were diluted 1:5 in blocking buffer and $50 \mu \mathrm{l}$ of each dilution was incubated in the wells for 1 hour. After washing 3 times with $200 \mu \mathrm{l}$ washing buffer (HBS containing $0.03 \%$ Tween-20), $50 \mu \mathrm{l}$ of a peroxidase-conjugated monoclonal anti-human TFPI antibody against Kunitz-2 (MW1845, Sanquin) diluted $1 / 1000$ in HBS containing $5 \mathrm{mg} / \mathrm{ml}$ BSA was added $(2 \mu \mathrm{g} / \mathrm{ml}$ final concentration) to the wells and incubated for 1 hour. After 5 times washing with $200 \mu \mathrm{l}$ washing buffer, peroxidase activity was determined by chromogenic substrate conversion (TMB enzymatic kit, Pierce, Rockford IL, USA) according to the manufacturer's instructions. Serial dilutions of normal pooled plasma were used as standards. Peroxidase conjugation of monoclonal anti-human TFPI was performed according to the manufacturer's instructions (Pierce). Recombinant full-length TFPI and truncated TFPI (1-161) were a kind gift from Dr. T. Lindhout from our institute.

\section{Preparation of synthetic modules of TFPI for ELISA validation}

Kunitz-2 (amino acid 92-150; 3 disulfides) Kunitz-3 (amino acid 182-241; 3 disulfides), and the C-terminus (amino acid 242-276) of TFPI were synthesized by tBoc solid phase peptide synthesis as $\mathrm{N}$-acetylated, C-amidated peptides as described, except for the C-terminus, which contained a C-terminal carboxylic acid ${ }^{20}$. Oxidative folding of the crude Kunitz modules was performed with $1 \mathrm{mM}$ cystine/8 $\mathrm{mM}$ cysteine to yield internal disulfide-bridged Kunitz domains, which were purified by HPLC and lyophilized. Electrospray-ionization quadrupole mass spectrometry revealed masses of $7008.8 \pm 0.4$ for Kunitz-2 (theoretical monoisotopic mass: 7006.1; average mass: 7010.8) and 6887.1 \pm 0.8 for Kunitz-3 (theoretical monoisotopic mass: 6884.2; average mass: 6888.8), in both cases confirming a mass decrease of 6 units 
compared to the reduced states of Kunitz domains, representing the loss of 6 protons due to the formation of 3 disulfide bonds.

FXa inhibition by synthetic TFPI modules

FXa (0.2 nM final concentration) in HBS containing $3 \mathrm{mM} \mathrm{CaCl}_{2}$, and $30 \mathrm{mg} / \mathrm{ml} \mathrm{BSA}$ was incubated with the synthetic TFPI modules in $150 \mu \mathrm{l}$ at $37^{\circ} \mathrm{C}$. After $45 \mathrm{~min}, 50 \mu \mathrm{l}$ chromogenic substrate S2765 (Chromogenix, Malmö, Sweden) was added to $125 \mu \mathrm{M}$ final concentration. Conversion of S2765 was measured in a 96-well plate reader. FXa activity was expressed as the linear fit of the first 4 minutes of substrate conversion. Inhibition of FXa was expressed as $\%$ of the FXa activity determined in the absence of Kunitz modules.

\section{Statistical analysis}

Data were expressed as mean \pm standard deviation. Population means were compared by Student's t-test. Correlations were expressed as Pearson coefficients ( $r$ ). 


\section{RESULTS}

Functional assays for the TFPI/protein S anticoagulant pathway

Thrombin generation was initiated with a low TF concentration (1.5 pM) in George King normal plasma (GKP) and in normal pooled plasma (NPP). Prior to thrombin generation, plasma was incubated with $\mathrm{CTI}$ in the absence or presence of neutralizing antibodies against protein S or TFPI for 15 minutes at $37^{\circ} \mathrm{C}$. Antibodies against TFPI were directed against the Cterminal domain, which is required for optimal inhibition of $\mathrm{FXa}^{21,22}$ and stimulation by protein $\mathrm{S}^{9}$.
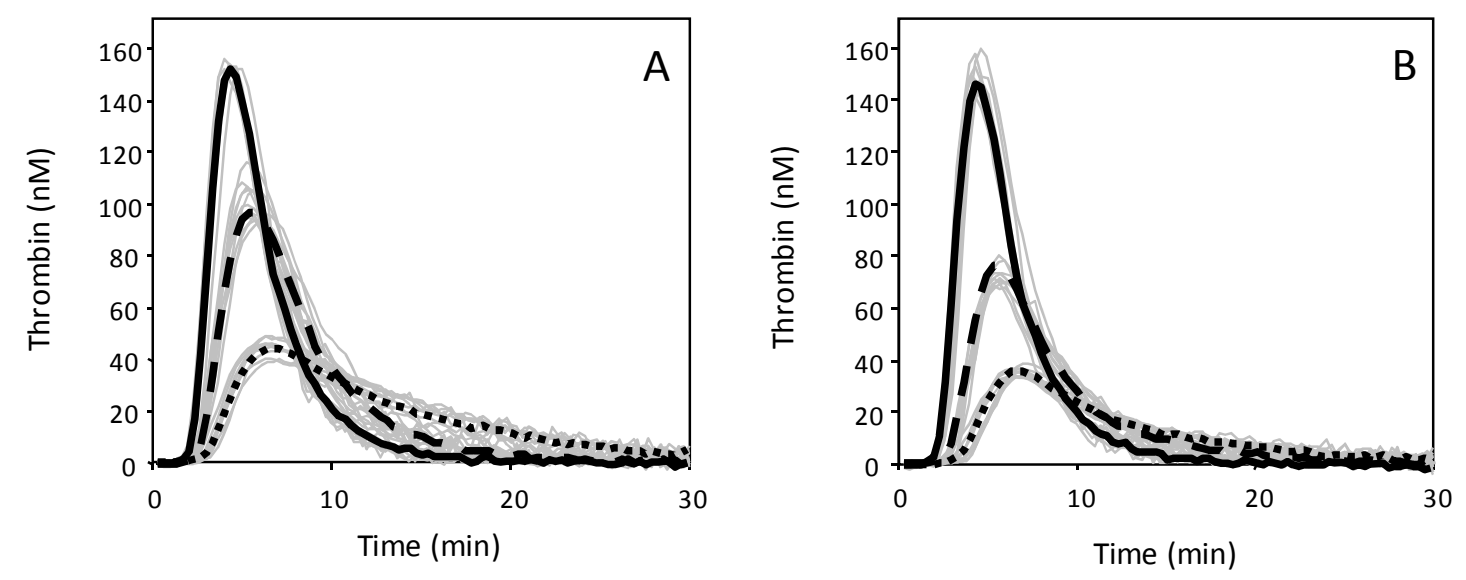

FIGURE 3.1: Effects of anti-protein $S$ and anti-TFPI antibodies on thrombin generation at low

(1.5 pM) TF. Average of 12 separate thrombin generation curves (grey) representing the inter-assay variation in (A) George King normal pooled plasma (GKP) or in (B) normal pooled plasma (NPP) without addition of antibodies (dotted line), with anti-protein $\mathrm{S}$ antibodies (dashed line) or anti-TFPI antibodies (solid line).

The inter- and intra assay variations of the peak heights of the thrombin generation curves were determined by performing the assay 12 times in duplicate (Table 3.1). For the inter-assay variation, the average peak height in the absence of antibodies was $45.7 \mathrm{nM}$ for GKP and $36.0 \mathrm{nM}$ for NPP, respectively (Fig. 3.1). Addition of inhibitory antibodies to protein S resulted in an increase of the thrombin peak to $100.9 \mathrm{nM}$ for GKP and $73.1 \mathrm{nM}$ for NPP, respectively, due to the inhibition of the TFPI-cofactor activity of protein S (Table 3.1; Fig. 3.1). Complete inhibition of the TFPI/protein S system through addition of inhibitory antibodies against TFPI resulted in an increase in peak height to $153.8 \mathrm{nM}$ for GKP and $149.5 \mathrm{nM}$ for NPP, respectively (Table 3.1; Fig. 3.1). The anticoagulant activities of protein $\mathrm{S}$ and TFPI were expressed as the ratio of the peak heights obtained in the absence and presence of the 
respective antibodies. The protein S-ratios in these normal pooled plasmas were $0.45-0.49$ meaning that under these conditions protein S, via its TFPI-cofactor activity, reduced thrombin generation by more than $50 \%$. The TFPI-ratios were $0.21-0.30$, indicating that the TFPI/protein $S$ system as a whole reduced thrombin generation by $\sim 75 \%$. The inter- and intra-assay coefficients of variation (CV) of all parameters determined with these assays were $\leq 7 \%$ (Table 3.1).

Table 3.1. Inter- and intra-assay variations of the protein S and TFPI activity assays.

\begin{tabular}{|c|c|c|c|c|c|}
\hline $\begin{array}{l}\text { Inter-Assay variation } \\
\qquad(\mathrm{n}=12)\end{array}$ & Plasma & $\begin{array}{c}\text { Plasma + } \\
\alpha \text {-protein S }\end{array}$ & $\begin{array}{c}\text { Plasma + } \\
\alpha \text {-TFPI }\end{array}$ & $\begin{array}{c}\text { Protein S } \\
\text { Ratio }\end{array}$ & $\begin{array}{l}\text { TFPI } \\
\text { Ratio }\end{array}$ \\
\hline Peak height (nM Ila) & $45.7 \pm 3.2$ & $100.9 \pm 7.4$ & $153.8 \pm 6.2$ & $0.45 \pm 0.02$ & $0.30 \pm 0.02$ \\
\hline George King Plasma & CV: $7 \%$ & CV: $7 \%$ & CV: $4 \%$ & CV: $5 \%$ & CV: $7 \%$ \\
\hline Peak height (nM Ila) & $36.0 \pm 2.0$ & $73.1 \pm 5.3$ & $149.5 \pm 5.2$ & $0.49 \pm 0.02$ & $0.24 \pm 0.01$ \\
\hline Normal Pooled Plasma & CV: $6 \%$ & CV: $7 \%$ & $C V: 3 \%$ & $C V: 5 \%$ & $C V: 6 \%$ \\
\hline $\begin{array}{l}\text { Intra-Assay variation } \\
\qquad(\mathrm{n}=12)\end{array}$ & Plasma & $\begin{array}{c}\text { Plasma + } \\
\alpha \text {-protein S }\end{array}$ & $\begin{array}{c}\text { Plasma + } \\
\alpha-\text { TFPI }\end{array}$ & $\begin{array}{c}\text { Protein S } \\
\text { Ratio }\end{array}$ & $\begin{array}{l}\text { TFPI } \\
\text { Ratio }\end{array}$ \\
\hline Peak height (nM Ila) & $47.2 \pm 2.5$ & $105.2 \pm 5.5$ & $156.6 \pm 3.9$ & $0.45 \pm 0.03$ & $0.30 \pm 0.01$ \\
\hline George King Plasma & CV: $5 \%$ & CV: $5 \%$ & CV: $2 \%$ & CV: $7 \%$ & CV: $5 \%$ \\
\hline Peak height (nM Ila) & $30.4 \pm 1.1$ & $64.6 \pm 3.0$ & $143.4 \pm 4.0$ & $0.47 \pm 0.03$ & $0.21 \pm 0.01$ \\
\hline Normal Pooled Plasma & CV: $4 \%$ & CV: $5 \%$ & CV: $3 \%$ & CV: $6 \%$ & CV: $6 \%$ \\
\hline
\end{tabular}

Data are expressed as mean \pm SD

\section{Development of a full-length TFPI ELISA}

Since protein S only stimulates full-length TFPI (TFPI $\mathrm{FL})$ and since full-length TFPI is the molecular form of TFPI that is most active in down-regulating the TF pathway, an ELISA was developed that enables quantification of the plasma levels of this form of TFPI. TFPI FL was quantified using a capturing monoclonal antibody against the C-terminus and a peroxidaseconjugated monoclonal antibody against the Kunitz-2 domain of TFPI for detection (Fig. 3.2A). TFPI $_{\mathrm{FL}}$ was detectable in normal plasma but not in TFPI-depleted plasma (Fig. 3.2B). In 
addition, purified recombinant TFPI $\mathrm{FL}_{\mathrm{F}}$ was detected by the ELISA, whereas purified truncated TFPI (TFPI ${ }_{1-161}$ ) lacking the C-terminal portion was not (Fig. 3.2C).
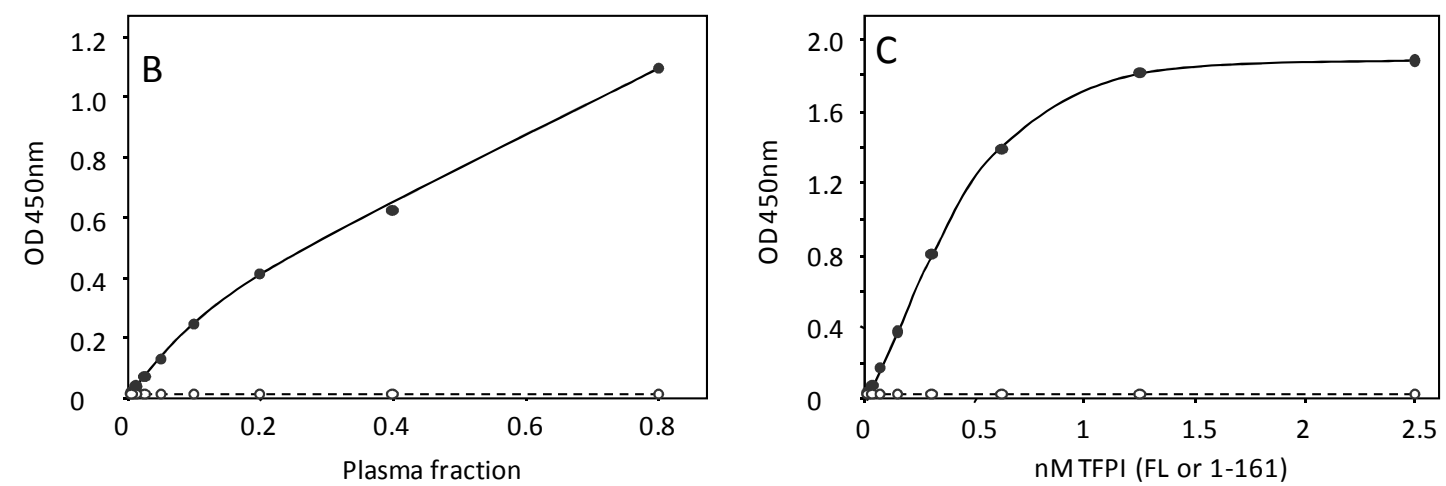

FIGURE 3.2: Design of a full-length TFPI ELISA. A) Full-length TFPI present in plasma was captured by monoclonal antibodies against the C-terminus (C-term) and detected by peroxidase-conjugated monoclonal antibodies against Kunitz-2 (K2) of TFPI. Arrow (161) indicates the C-terminal residue of truncated TFPI. B) Calibration curve of normal pooled plasma $(\mathbf{O})$ and TFPI-depleted plasma (O). C) Calibration curve of TFPI-depleted plasma reconstituted with either purified full-length TPFI (0) or truncated TFPI $\mathrm{I}_{1-161}(\bigcirc)$. Averages of duplicate measurements are shown.

To validate the $\mathrm{TFPI}_{\mathrm{FL}}$ ELISA, competition experiments were performed with chemically synthesized TFPI domains (Kunitz-2, Kunitz-3 and the C-terminus). As an example Kunitz-2 is shown (Fig 3.3A), whose observed mass after folding was $7008.8 \pm 0.4$, which fitted well between the theoretical masses of 7006.1 (monoisotopic mass) and 7010.8 (average mass) (Fig. 3.3B). To determine if the folded Kunitz-2 domain adopted a native-like conformation, its activity as a FXa-inhibitor was determined. Kunitz-2 caused a dosedependent inhibition of FXa activity reaching total inhibition at concentrations >5 $\mu \mathrm{M}$, whereas Kunitz-3 and the C-terminus did not inhibit FXa (Fig. 3.3C). A reciprocal fit of data (not shown) indicated that half-maximal FXa inhibition occurred at $0.18 \mu \mathrm{M}$ Kunitz-2. 

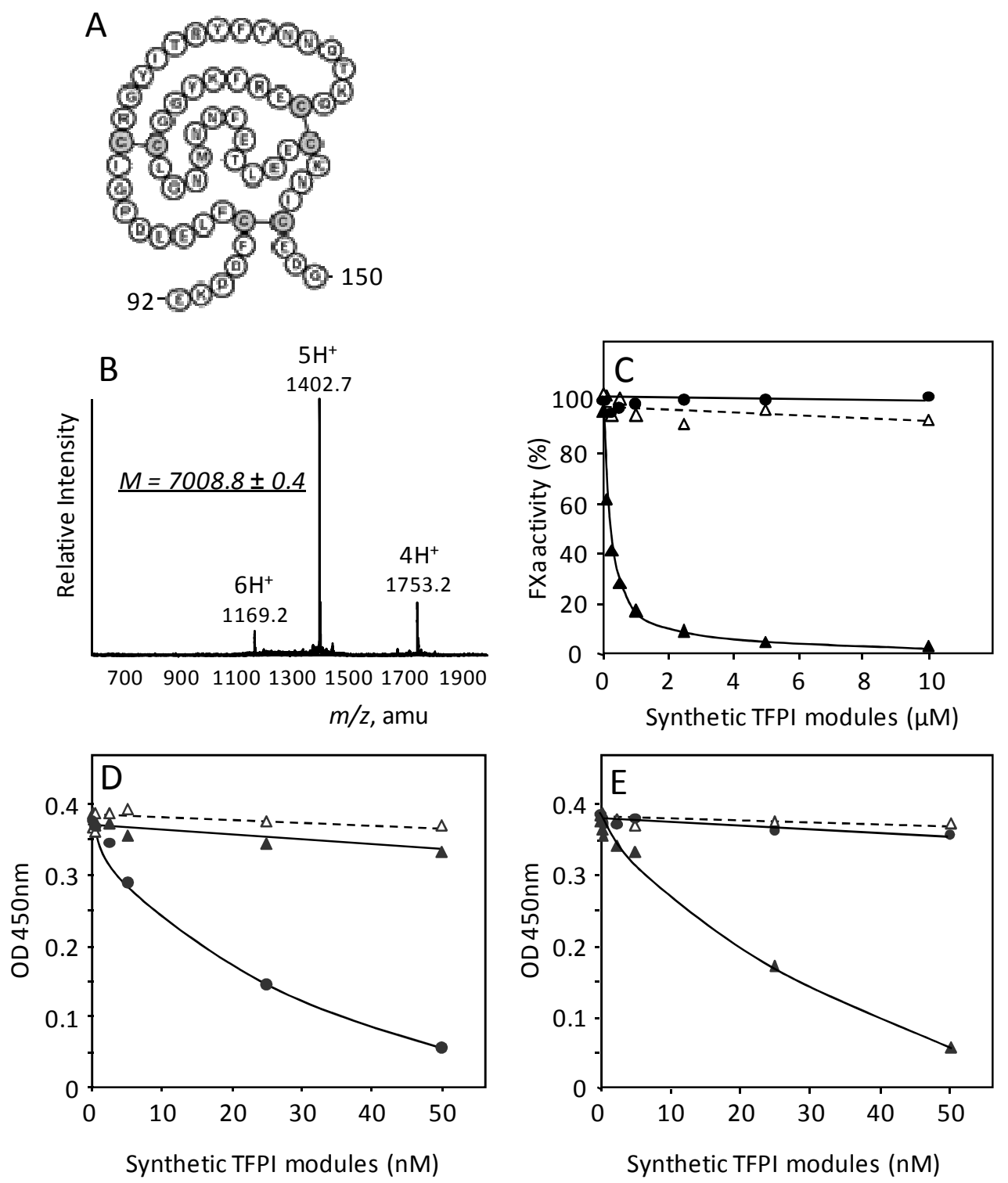

FIGURE 3.3: Validation of the full-length TFPI ELISA with synthetic TFPI modules. A) Secondary structure of Kunitz-2 domain of TFPI. B) Electrospray-ionization mass spectrum of purified folded synthetic Kunitz-2 domain of TFPI. The observed mass fits well between the theoretical monoisotopic mass of 7006.1 and the average mass: 7010.8. C) Inhibition of FXa activity by synthetic TFPI modules Kunitz-2 $(\mathbf{\Delta})$, Kunitz-3 $(\triangle)$, and C-terminus ( $(\mathbf{)}$.D) competition between full-length TFPI and Kunitz-2 $(\mathbf{\Delta})$, Kunitz-3 $(\triangle)$, and C-terminus $(\bullet)$ domains added to normal pooled plasma (1:5 dilution) during the capture phase of the full-length TFPI ELISA. E) competition between full-length TFPI and Kunitz-2 $(\mathbf{\Delta})$, Kunitz-3 $(\triangle)$, and C-terminus $(\bullet)$ domains added together with the peroxidase-conjugated antibody during the detection phase of the full-length TFPI ELISA. Averages of duplicate measurements are shown $(C, D$, and $E)$.

Subsequently, we performed the TFPI ELISA on diluted normal pooled plasma (1:5) containing varying amounts Kunitz-2, Kunitz-3 or C-terminus of TFPI. Only the C-terminus was able to inhibit the binding of plasma TFPI $\mathrm{FL}_{\mathrm{F}}$ to the capturing antibody, whereas Kunitz-2 and 
Kunitz-3 had no effect on the TFPI $\mathrm{FL}_{\mathrm{L}}$ ELISA (Fig. 3.3D). When synthetic modules were added during the detection step, only Kunitz-2 inhibited detection of $\mathrm{TFPI}_{\mathrm{FL}}$ in plasma (Fig. 3.3E).

\section{TFPI/protein S activity in plasma from normal individuals}

Thrombin generation and protein S- and TFPI-ratios were determined in 85 healthy normal individuals of which 48 males and 37 females (Fig. 3.4, Table 3.2). The average peak height of thrombin generation in the absence of antibodies was $38.3 \pm 5.8 \mathrm{nM}$ Ila and was different between males and females (males: $33.2 \pm 11.3 \mathrm{nM}$; females: $45.0 \pm 29.9 \mathrm{nM}$; $p=0.014)$. In the presence of anti-protein $S$ antibodies the average peak height increased to $77.1 \pm 28.3 \mathrm{nM}$ and was not significantly different anymore between males and females $(p=0.07)$. In the presence of anti-TFPI antibodies peak height increased to $150.5 \pm 31.9 \mathrm{nM}$ and was the same for males and females ( $p=0.7$ ) (Fig. 3.4). Therefore, the differences between the protein S- and TFPI-ratios of males and females originated from differences in peak heights of thrombin generation determined in the absence of antibodies, in which females have a significantly higher peak height than males (Table 3.2). The protein S- and TFPI-ratios were $0.48 \pm 0.10$ and $0.25 \pm 0.09$, respectively.
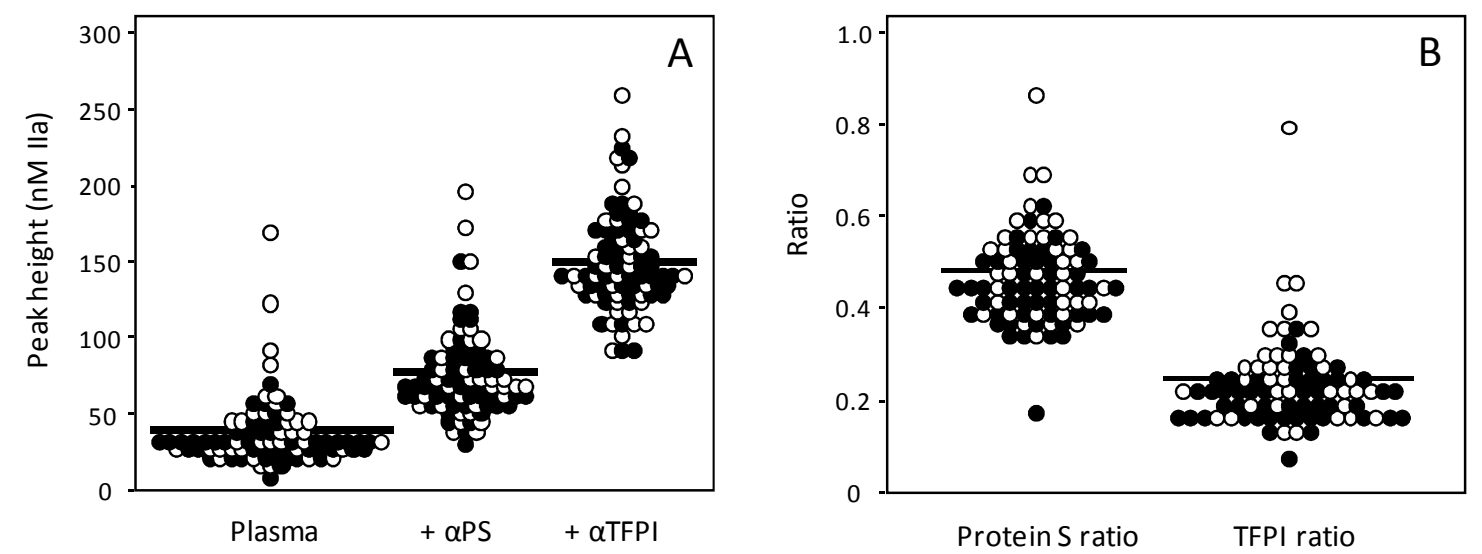

FIGURE 3.4: Functional TFPI/protein S assays in normal individuals. (A) Peak height of thrombin generation in the presence or absence of antibodies against protein $S(\alpha P S)$ or TFPI ( $\alpha$ TFPI) in plasma from 37 women $(O)$ and 48 men (O). (B) protein S-ratio (TFPI-cofactor activity of protein S) and TFPIratio (activity of the TFPI/protein $\mathrm{S}$ system) determined with the thrombin generation-based assay in plasma of 37 women $(\bigcirc)$ and 48 men $(\bullet)$.

Plasma protein $\mathrm{S}, \mathrm{TFPI}_{\mathrm{FL}}$, free TFPI antigen levels and total TFPI activity were measured in the 85 healthy individuals (Table 3.2). Total and free protein S levels were significantly lower in females than in males. No correlation was found between TFPI-cofactor activity of 
protein S (protein S-ratio) and the level of total or free protein S (Fig. 3.5A), whereas free TFPI and TFPI $\mathrm{FL}_{\text {L }}$ levels (Table 3.2) showed a strong correlation ( $r=0.834$, Fig. 3.5B). Females had a significantly lower level of $\operatorname{TFPI}_{\mathrm{FL}}(84 \mathrm{U} / \mathrm{dl})$ than men $(100 \mathrm{U} / \mathrm{dl})$. A significant inverse correlation $(r=-0.479, p<0.001)$ was found between levels of TFPI $\mathrm{FL}_{\mathrm{L}}$ and the protein S-ratio (Fig. 3.5C). In addition, a strong correlation was found between the levels of TFPI $\mathrm{FL}_{\mathrm{L}}$ and the levels of total protein $S(r=0.529, p<0.001)$ (Fig. 3.5D) and free protein $S(r=0.597, p<0.001)$ (data not shown).

Table 3.2. Protein S and TFPI activity assays in normal individuals

\begin{tabular}{|l|c|c|}
\hline & Males ( $\mathbf{n}=48)$ & Females (n= 37) \\
\hline Peak height $(\mathrm{nM})$ & $33.2 \pm 11.3$ & $45.0 \pm 29.9^{*}$ \\
\hline Peak height $+\alpha$ protein S (nM) & $72.2 \pm 20.7$ & $83.4 \pm 35.2$ \\
\hline Peak height $+\alpha$ TFPI (nM) & $149.8 \pm 26.8$ & $0.51 \pm 0.11^{*}$ \\
\hline PS-ratio & $0.45 \pm 0.08$ & $0.28 \pm 0.12^{*}$ \\
\hline TFPI-ratio & $0.22 \pm 0.05$ & $84 \pm 17^{* *}$ \\
\hline Free Protein S (U/dl \pm S.D.) & $102 \pm 16$ & $85 \pm 16^{* *}$ \\
\hline Total protein S (U/dl \pm S.D.) & $98 \pm 14$ & $83 \pm 21^{* *}$ \\
\hline Free TFPI (U/dl \pm S.D.) & $99 \pm 16$ & $84 \pm 23^{* *}$ \\
\hline Full-length TFPI (U/dl \pm S.D.) & $100 \pm 17$ & $96 \pm 37^{*}$ \\
\hline TFPI activity (U/dl \pm S.D.) & $115 \pm 41$ & 0.8 \\
\hline
\end{tabular}

Data are expressed as mean \pm SD

** $\mathrm{p}<0.001$

${ }^{*} \mathrm{p}<0.05$

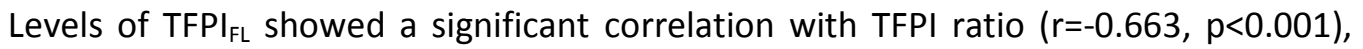
meaning that the anticoagulant activity of the TFPI/ protein S system is influenced by the level of full-length TFPI (Fig. 3.5E). The total TFPI activity (which comprises all forms of TFPI that contain Kunitz-2) was measured with a commercial two-stage chromogenic assay. No

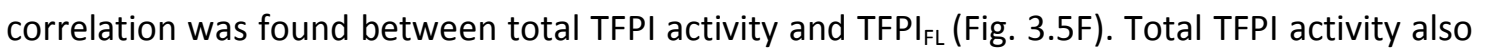


did not correlate with the protein S-ratio $(r=0.148)$, in line with the concept that TFPI $\mathrm{FL}_{\mathrm{L}}$ is the only active form of TFPI in the TFPI/protein S pathway.
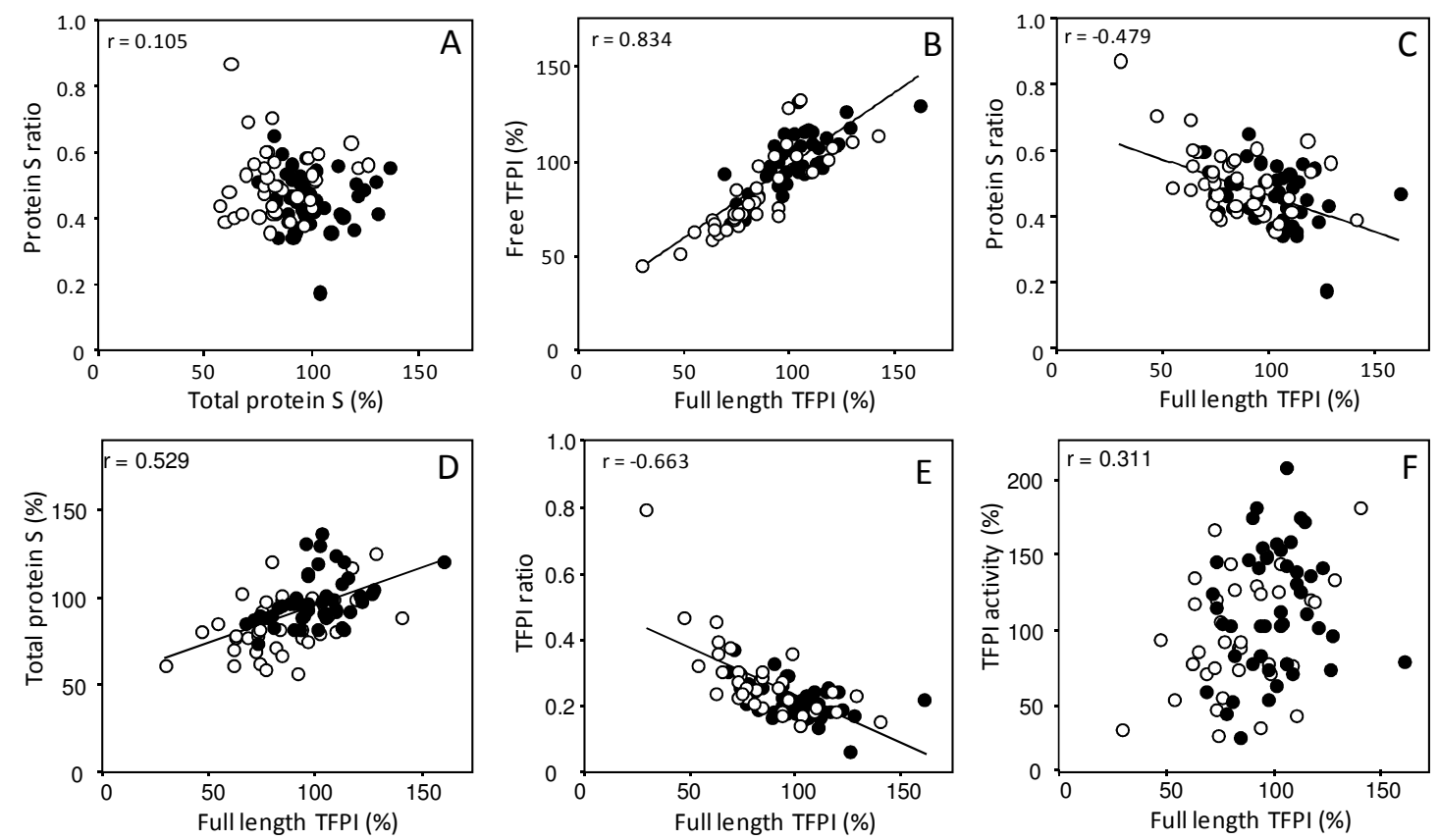

FIGURE 3.5: Correlations between coagulation parameters. Correlations between levels of total protein $\mathrm{S}$ and thrombin generation-based protein S-ratios (A), levels of full-length and free TFPI (B), levels of full-length TFPI and protein S-ratios (C), levels of full-length TFPI and total protein S (D), levels of full-length TFPI and TFPI-ratio (E), levels of full-length TFPI and total TFPI activity determined with the commercial chromogenic assay $(\mathbf{F})$, determined in plasma from healthy individuals, 37 females $(O)$ and 48 males (๑).

\section{TFPI/protein S activity in plasma from protein S-deficient individuals}

To explore the potential application of the assays for the TFPI/protein S pathway, we determined protein S- and TFPI-ratios in 18 protein S-deficient individuals (total protein S: $53.4 \pm 10.4 \mathrm{U} / \mathrm{dl}$, free protein $\mathrm{S}: 38.5 \pm 9.7 \mathrm{U} / \mathrm{dl}$ ), of whom 7 had experienced thrombosis, and in 17 normal family members (total protein S: $91.8 \pm 13.8 \mathrm{U} / \mathrm{dl}$, free protein S: $86.0 \pm 15.5 \mathrm{U} / \mathrm{dl}$ ), of whom 2 had experienced thrombosis (Table 3.3). Peak heights of thrombin generation curves without antibodies were significantly higher in protein S-deficient individuals (119.4 $\pm 33.6 \mathrm{nM}$ ) than in normal family members $(67.5 \pm 28.3 \mathrm{nM}$ ) (Fig. 3.6A). When anti-protein $\mathrm{S}$ antibodies were added, the peak heights increased in both protein S-deficient individuals $(149.5 \pm 30.7$ $\mathrm{nM})$ and in normal family members (131.2 $\pm 27.9 \mathrm{nM}$ ) (Fig. 3.6B). Although the thrombin peak was still higher in the protein S-deficient individuals than in normal family members, the difference between the two groups was no longer significant, suggesting that the difference in 
peak height in the absence of antibodies was mainly due to differences in protein S levels. After the addition of anti-TFPI antibodies, peak heights became the same and increased to 188.5 $\pm 31.3 \mathrm{nM}$ and $193.2 \pm 18.5 \mathrm{nM}$ for protein S-deficient patients and normal family members, respectively (Fig. $3.6 \mathrm{C}$ ). This suggests that TFPI $\mathrm{FL}_{\mathrm{L}}$ was responsible for the higher thrombin generation in protein S-deficient patients observed in the presence of anti-protein S antibodies. The protein S-ratio was higher in the protein S-deficient individuals $(0.79 \pm 0.11)$ compared to their normal family members $(0.50 \pm 0.12)$ (Table 3.3). The TFPI-ratio was also significantly higher in the protein S-deficient individuals $(0.63 \pm 0.13)$ than in their normal family members $(0.35 \pm 0.12)$. These differences are likely caused by a combination of decreased levels of protein S and TFPI in the protein S-deficient individuals (Table 3.3).
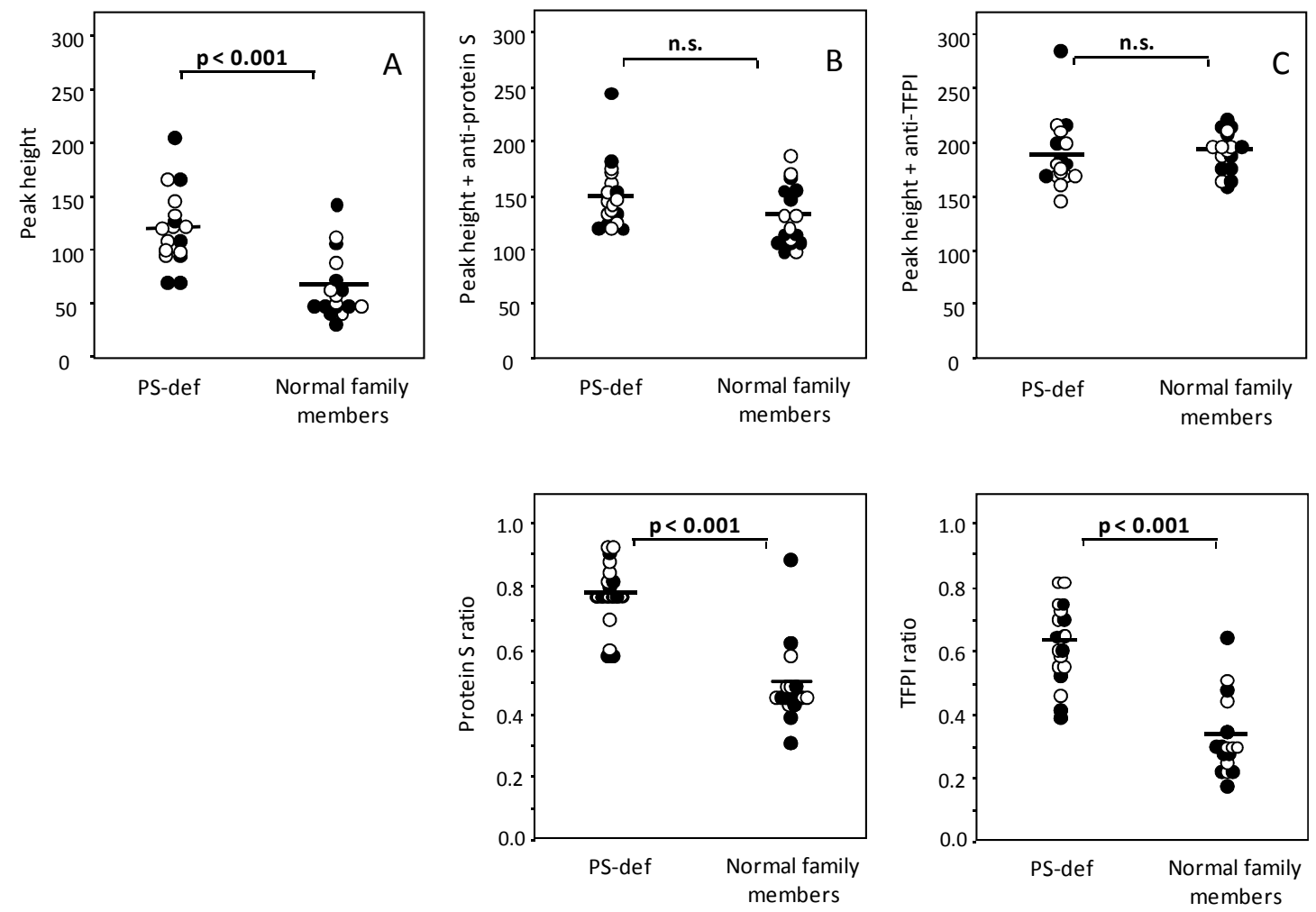

FIGURE 3.6: Thrombin generation in protein S-deficient individuals and normal family members. Peak heights of thrombin generation determined in absence of antibodies (A), in the presence of anti-protein $\mathrm{S}$ antibodies (B), or in the presence of anti-TFPI antibodies (C) and the protein S-ratio (D) and TFPI-ratio (E) in plasma from 18 male $(\mathbf{O})$ or female $(O)$ protein S-deficient individuals of which 7 have experienced with thrombosis, and from 17 family members of which 2 have experienced with thrombosis. 
Table 3.3. Protein S and TFPI activity assays in families with protein S deficiency

\begin{tabular}{|l|c|c|}
\hline & $\begin{array}{c}\text { Normal family members } \\
(\mathbf{n = 1 7})\end{array}$ & $\begin{array}{c}\text { Protein S-deficient } \\
\text { individuals (n= 18) }\end{array}$ \\
\hline Peak height (nM Ila) & $67.5 \pm 28.3$ & $119.4 \pm 33.6^{* *}$ \\
\hline Peak height $+\alpha$ protein S (nM Ila) & $131.2 \pm 27.9$ & $149.5 \pm 30.7$ \\
\hline Peak height $+\alpha$ TFPI (nM Ila) & $193.2 \pm 18.5$ & $188.5 \pm 31.3$ \\
\hline PS-ratio & $0.50 \pm 0.12$ & $0.79 \pm 0.11^{* *}$ \\
\hline TFPI-ratio & $0.35 \pm 0.13 \pm 0.12^{* *}$ \\
\hline Free protein S (U/dl \pm S.D.) & $86 \pm 15$ & $38 \pm 10^{* *}$ \\
\hline Total protein S (U/dl \pm S.D..) & $92 \pm 14$ & $53 \pm 10^{* *}$ \\
\hline Free TFPI (U/dl \pm S.D.) & $90 \pm 24$ & $56 \pm 17^{* *}$ \\
\hline Full-length TFPI (U/dl \pm S.D.) & $104 \pm 32$ & $67 \pm 19^{* *}$ \\
\hline
\end{tabular}

Data are expressed as mean \pm SD

** $\mathrm{p}<0.001$

Due to the small size of the population, no conclusive relations between protein S- and TFPIratios and thrombotic events could be established.

In contrast to the population of normal individuals, and to the population of normal family members, a correlation between protein S levels and the protein S-ratio was observed $(r=-0.527)$ in the protein S-deficient population (Fig. 3.7A). It is interesting to note that TFPI $\mathrm{FL}$ levels were significantly decreased in plasma of protein S-deficient patients and correlated with protein S levels in both protein S-deficient individuals and in their family members (Fig. 3.7B). 

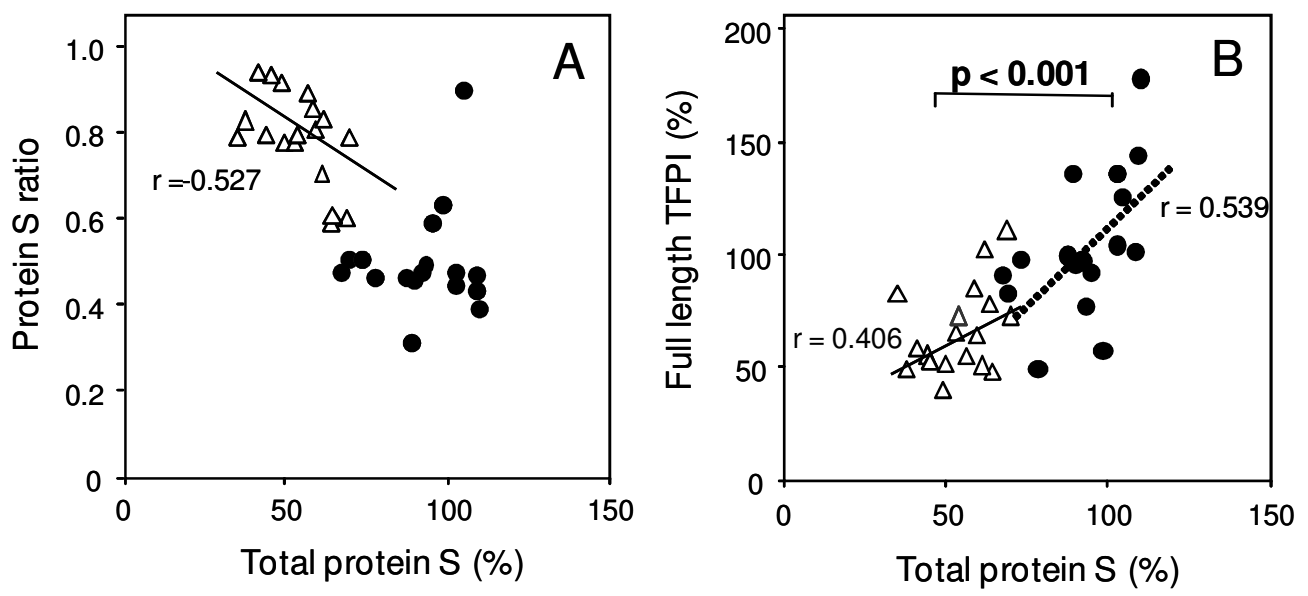

FIGURE 3.7: Protein S and full-length TFPI levels in protein S-deficient individuals and normal family members. (A) Correlation between total protein $S$ levels and the thrombin generation-based protein S-ratio in plasma from 18 protein S-deficient individuals $(\Delta)$ and 17 normal family members $(0)$. (B) Correlation between total protein $\mathrm{S}$ and full-length TFPI levels in plasma from 18 protein S-deficient individuals $(\Delta)$ and 17 normal family members $(\bullet)$. 


\section{DISCUSSION}

Thrombin generation-based assays for quantification of the activity of the $\mathrm{TFPI} /$ protein S system were developed using commercially available reagents. In these assays thrombin generation was initiated with a low trigger (1.5 pM TF) because the ability of the TFPI/protein S system to inhibit the extrinsic coagulation pathway depends on the TF concentration ${ }^{8,9}$. The TFPI-cofactor activity of protein $\mathrm{S}$ and the overall anticoagulant activity of the TFPI/protein S system were expressed as ratios of peak heights of thrombin generation curves determined without and with antibodies against protein S or TFPI. In normal plasma, the protein S-ratio was $\sim 0.5$, meaning that under the experimental conditions used protein $S$ reduced thrombin generation by $50 \%$ via its ability to act as cofactor of TFPI. The TFPI-ratio was $\sim 0.25$, meaning that the TFPI/protein $S$ pathway reduced thrombin generation by $\sim 75 \%$. All measurements showed intra- and inter-assay coefficients of variation of $7 \%$ or lower. The differences between NPP and GKP in the absolute peak heights of thrombin generation are most likely due to differences in citrate concentration (3.2\% and $3.8 \%$ respectively), but can also depend on the number of individuals contributing to the pool ( $n=98$ and $n=20$, respectively) and/or to plasma handling. Nevertheless, protein S and TFPI/protein S activities, expressed as ratios of peak heights, showed only minor differences between NPP and GKP, making the described assay suitable for different plasma preparations.

An important feature of this assay is the TF concentration used for initiation. High TF concentrations lead to high FXa concentrations reaching beyond regulation by the TFPI/protein S anticoagulant pathway. In our hands, a TF concentration of $\sim 1.5 \mathrm{pM}$ was optimal for the detection of the activity of the TFPI/protein S system. Since no commercial source with this TF concentration was available, we have mixed two commercial reagents to obtain a final concentration of $1.5 \mathrm{pM}$ TF and $4 \mu \mathrm{M}$ of phospholipids. As thrombin generation assays will vary slightly in different lab settings, the best strategy for getting optimal sensitivity for the TFPI/protein S system is to use a TF concentration that yields a peak height of thrombin generation of $\sim 40 \mathrm{nM}$ in the absence of antibodies. As thrombin generation is relatively low and slow under these conditions, it is recommended to add CTI to avoid any unwanted contribution of contact activation ${ }^{23}$.

The thrombin generation-based TFPI/protein S activity assays were applied to plasma of 85 healthy individuals and compared with the antigen levels of protein S and TFPI. In normal individuals, the inhibitory activity of protein S (protein S-ratio) correlated with TFPI $\mathrm{FL}_{\mathrm{F}}$ levels, but not with protein S levels. The absence of a correlation between protein $\mathrm{S}$ level and 
the TFPI-cofactor activity of protein $S$ in normal individuals might be due to the fact that normal protein S levels are not rate-limiting for TFPI-cofactor activity.

The activity of the TFPI/protein S system was also measured in plasma from individuals with (partial) protein $\mathrm{S}$ deficiency and their unaffected family members. The average peak heights of thrombin generation in the family study from Italy were, like those in GKP, higher as those observed in NPP and the normal population, which may be attributed to their higher citrate concentration (3.8\%). However, like with GKP, the protein S- and TFPIratios were normal among the normal family members ( $\sim 0.5$ and $\sim 0,35$, respectively). Protein S-deficient individuals showed reduced activity of the TFPI/protein S system (higher protein Sand TFPI-ratios) when compared to the population of unaffected family members. The difference between the two groups largely disappeared upon addition of anti-protein $S$ antibodies, indicating that the low protein $S$ levels were responsible for the impairment of the $\mathrm{TFPI} /$ protein S pathway in the protein S-deficient individuals. The remaining difference in peak height between protein S-deficient and normal individuals determined in the presence of antiprotein $\mathrm{S}$ antibodies was explained by $\mathrm{TFPI}_{\mathrm{FL}}$ levels, which were lower in protein S-deficient individuals than in their normal family members. Protein $\mathrm{S}$ levels are known to co-vary with (free) TFPI levels (Fig 3.5D) ${ }^{24}$, and a decrease of TFPI levels in conjunction with protein S deficiency will exacerbate the procoagulant phenotype. The reason for the correlation between protein S and TFPI is unknown, but both are synthesized and secreted by endothelial cells, which might be regulated by common biological mechanisms.

In conclusion, we have developed functional assays for the TFPI/protein S system as well as an ELISA for TFPI $\mathrm{FL}_{\mathrm{F}}$, the form of TFPI that is active in the TFPI/protein S anticoagulant pathway. These assays pave the way for a better characterization of the role of protein $S$ in the TFPI anticoagulant pathway in the near future. Our data suggest that the decreased levels of protein S or full length TFPI in protein S deficient patients result in a hypercoagulable state due to a reduced activity of the TFPI/protein S anticoagulant mechanism, which will likely contribute to the increased risk of venous thrombosis of protein S-deficient individuals ${ }^{15,25}$. 


\section{REFERENCES}

1. DiScipio RG, Davie EW. Characterization of protein $\mathrm{S}$, a gamma-carboxyglutamic acid containing protein from bovine and human plasma. Biochemistry. 1979;18:899-904.

2. Walker FJ. Regulation of activated protein $\mathrm{C}$ by a new protein. A possible function for bovine protein S. J Biol Chem. 1980;255:5521-5524.

3. Koedam JA, Meijers JC, Sixma JJ, Bouma BN. Inactivation of human factor VIII by activated protein C. Cofactor activity of protein $\mathrm{S}$ and protective effect of von Willebrand factor. J Clin Invest. 1988;82:1236-1243.

4. Heeb MJ, Mesters RM, Tans G, Rosing J, Griffin JH. Binding of protein S to factor Va associated with inhibition of prothrombinase that is independent of activated protein C. J Biol Chem. 1993;268:2872-2877.

5. Hackeng TM, van 't Veer C, Meijers JC, Bouma BN. Human protein S inhibits prothrombinase complex activity on endothelial cells and platelets via direct interactions with factors $\mathrm{Va}$ and $\mathrm{Xa}$. J Biol Chem. 1994;269:21051-21058.

6. Sere KM, Janssen MP, Willems GM, Tans G, Rosing J, Hackeng TM. Purified protein S contains multimeric forms with increased APC-independent anticoagulant activity. Biochemistry. 2001;40:8852-8860.

7. Koenen RR, Christella M, Thomassen LG, Tans G, Rosing J, Hackeng TM. Effect of oral contraceptives on the anticoagulant activity of protein $\mathrm{S}$ in plasma. Thromb Haemost. 2005;93:853-859.

8. Sere KM, Rosing J, Hackeng TM. Inhibition of thrombin generation by protein $\mathrm{S}$ at low procoagulant stimuli: implications for maintenance of the hemostatic balance. Blood. 2004;104:3624-3630.

9. Hackeng TM, Sere KM, Tans G, Rosing J. Protein S stimulates inhibition of the tissue factor pathway by tissue factor pathway inhibitor. Proc Natl Acad Sci U S A. 2006;103:3106-3111.

10. Ndonwi M, Broze G, Jr. Protein S enhances the tissue factor pathway inhibitor inhibition of factor Xa but not its inhibition of factor VIla-tissue factor. J Thromb Haemost. 2008;6:1044-1046.

11. Novotny WF, Brown SG, Miletich JP, Rader DJ, Broze GJ, Jr. Plasma antigen levels of the lipoprotein-associated coagulation inhibitor in patient samples. Blood. 1991;78:387-393.

12. Novotny WF, Girard TJ, Miletich JP, Broze GJ, Jr. Purification and characterization of the lipoprotein-associated coagulation inhibitor from human plasma. J Biol Chem. 1989;264:1883218837.

13. Broze GJ, Jr., Lange GW, Duffin KL, MacPhail L. Heterogeneity of plasma tissue factor pathway inhibitor. Blood Coagul Fibrinolysis. 1994;5:551-559.

14. Girard TJ, Warren LA, Novotny WF, et al. Functional significance of the Kunitz-type inhibitory domains of lipoprotein-associated coagulation inhibitor. Nature. 1989;338:518-520.

15. Schwarz HP, Fischer M, Hopmeier P, Batard MA, Griffin JH. Plasma protein S deficiency in familial thrombotic disease. Blood. 1984;64:1297-1300. 
16. Dahm A, Van Hylckama Vlieg A, Bendz B, Rosendaal F, Bertina RM, Sandset PM. Low levels of tissue factor pathway inhibitor (TFPI) increase the risk of venous thrombosis. Blood. 2003;101:4387-4392.

17. Dielis AW, Castoldi E, Spronk HM, et al. Coagulation factors and the protein C system as determinants of thrombin generation in a normal population. J Thromb Haemost. 2008;6:125-131.

18. Hemker HC, Giesen P, AlDieri R, et al. The calibrated automated thrombogram (CAT): a universal routine test for hyper- and hypocoagulability. Pathophysiol Haemost Thromb. 2002;32:249-253.

19. Maurissen LF, Thomassen MC, Nicolaes GA, et al. Re-evaluation of the role of the protein S-C4b binding protein complex in activated protein C-catalyzed factor Va-inactivation. Blood. 2008;111:3034-3041.

20. Schnolzer M, Alewood P, Jones A, Alewood D, Kent SB. In situ neutralization in Boc-chemistry solid phase peptide synthesis. Rapid, high yield assembly of difficult sequences. Int J Pept Protein Res. 1992;40:180-193.

21. Nordfang O, Bjorn SE, Valentin S, et al. The C-terminus of tissue factor pathway inhibitor is essential to its anticoagulant activity. Biochemistry. 1991;30:10371-10376.

22. Wesselschmidt R, Likert K, Girard T, Wun TC, Broze GJ, Jr. Tissue factor pathway inhibitor: the carboxy-terminus is required for optimal inhibition of factor Xa. Blood. 1992;79:2004-2010.

23. Mann KG, Whelihan MF, Butenas S, Orfeo T. Citrate anticoagulation and the dynamics of thrombin generation. J Thromb Haemost. 2007;5:2055-2061.

24. Dahm AE, Sandset PM, Rosendaal FR. The association between protein S levels and anticoagulant activity of tissue factor pathway inhibitor type 1. J Thromb Haemost. 2008;6:393-395.

25. Makris M, Leach M, Beauchamp NJ, et al. Genetic analysis, phenotypic diagnosis, and risk of venous thrombosis in families with inherited deficiencies of protein S. Blood. 2000;95:1935-1941. 



\section{Chapter 4:}

Type I and type III hereditary protein S deficiencies: Risk of venous thrombosis and underlying hypercoagulable state

submitted

Elisabetta Castoldi, Lisbeth F.A. Maurissen, Daniela Tormene, Luca Spiezia, Sabrina Gavasso, Claudia Radu, Tilman M. Hackeng, Jan Rosing, Paolo Simioni 



\section{SUMMARY}

Protein $\mathrm{S}$, circulating in plasma in free and bound form, is an anticoagulant protein that stimulates both activated protein $\mathrm{C}(\mathrm{APC})$ and tissue factor pathway inhibitor (TFPI). To evaluate the thrombosis risk associated with type I (low total and low free antigen) and type III (normal total and low free antigen) protein $\mathrm{S}$ deficiencies, we performed epidemiological, genetic and functional studies in protein S-deficient families. Kaplan-Meier analysis in 30 families (242 individuals) indicated that type I and III protein S deficiencies similarly predispose to thrombosis. To explain this finding, 23 families (132 individuals) were further characterized. Eleven PROS1 mutations ( 3 novel) were identified in these families. Type III deficient individuals were older and had higher protein S, TFPI and prothrombin levels than type I deficient individuals. Thrombin generation assays sensitive to the APC- and TFPIcofactor activities of protein $\mathrm{S}$ detected almost equivalent hypercoagulable states in plasma from type I and III deficient individuals, as the advantage conferred to type III deficient individuals by their higher protein S and TFPI levels was abolished by their older age and higher prothrombin levels. We conclude that hereditary type I and type III protein $S$ deficiencies are virtually equivalent risk factors for thrombosis. 


\section{INTRODUCTION}

Protein S (reviewed in ref. ${ }^{1}$ ) is a vitamin K-dependent glycoprotein mainly synthesized in the liver and present in plasma, platelets and endothelial cells. The mature protein comprises a Gla domain, a thrombin-sensitive region (TSR), four epidermal growth factor (EGF)-like domains and a large sex hormone-binding globulin (SHBG)-like domain. Plasma protein S $(350 \mathrm{nM})$ is distributed between two pools: $\sim 40 \%$ circulates free and $\sim 60 \%$ is bound to the complement regulatory factor C4b-binding protein (C4BP). ${ }^{2}$ Only C4BP molecules with a $\beta$-chain $\left(C 4 B P-\beta^{+}\right)$bind protein $S$ and, given the high affinity of this interaction, all C4BP- $\beta^{+}$ present in plasma ( $200 \mathrm{nM}$ ) is complexed with protein $\mathrm{S}^{3}$

Protein $\mathrm{S}$ is a potent anticoagulant protein that down-regulates thrombin formation via two mechanisms. ${ }^{4}$ On one hand it stimulates the proteolytic inactivation of coagulation factors (F) Va and VIIla by activated protein C (APC), ${ }^{5}$ and on the other hand it enhances the inhibition of FXa by tissue factor pathway inhibitor (TFPI). ${ }^{6,7}$ Although free protein $S$ is the most active form, recent reports indicate that the protein S-C4BP complex also retains part of the APC- and TFPI-cofactor activities. ${ }^{6,8}$ In the absence of protein S, both APC and TFPI are rather poor inhibitors of thrombin generation in plasma. ${ }^{6,9}$

Protein $\mathrm{S}$ deficiency is a rare coagulation disorder associated with an increased risk of venous thrombosis. ${ }^{10,11}$ It usually occurs as a partial (heterozygous) deficiency and segregates as an autosomal dominant trait. Presently, more than 200 mutations that impair protein $\mathrm{S}$ synthesis and/or function have been described in the protein $S$ gene (PROS1), and large deletions within the PROS1 locus have been identified as a relatively common cause of protein $\mathrm{S}$ deficiency. ${ }^{12}$ Based on protein $\mathrm{S}$ antigen and (APC-cofactor) activity levels, protein $\mathrm{S}$ deficiency is classified as type I (low total and low free antigen, reduced activity), type II (normal total and free antigen, reduced activity) and type III (normal total antigen, reduced free antigen and activity). However, since protein $S$ levels are strongly influenced by age, sex and hormonal status, ${ }^{13}$ as well as by several acquired conditions, the diagnosis of protein $\mathrm{S}$ deficiency states based on protein $\mathrm{S}$ levels is far from straightforward in practice. ${ }^{14}$

Type I and type III deficiencies account for $95 \%$ of protein S-deficient patients and often occur together in the same family as phenotypic variants of the same genetic defect (mixed type I/III deficiency). ${ }^{15}$ The reasons for the different phenotypic expression are poorly understood, but the age-dependent increase in total protein $S$ is thought to play a role, as type III protein S-deficient family members tend to be older than their type I deficient relatives. ${ }^{16}$ Differently, other families with protein $S$ deficiency only express the type III 
phenotype (pure type III deficiency). This type of protein S deficiency is often, but not always, ${ }^{17}$ associated with the PROS1 Ser ${ }^{460} \rightarrow$ Pro (Heerlen) mutation. ${ }^{18}$

Although protein $\mathrm{S}$ deficiency, and particularly low levels of free protein $\mathrm{S}^{19,20}$ are an established risk factor for venous thrombosis, risk estimates differ widely among studies, possibly reflecting the different severity of the underlying molecular defects. ${ }^{21}$ Moreover, the few epidemiological studies that distinguish between type I and type III deficiencies are rather contradictory with respect to the thrombosis risk associated with type III deficiency, which was found to be none, ${ }^{22}$ the same as in type I deficiency ${ }^{23}$ or intermediate. ${ }^{24}$ No risk of thrombosis is usually attributed to PROS1 Heerlen. ${ }^{18}$

To clarify this issue, we have re-evaluated the risk of thrombosis associated with type I and type III protein S-deficiencies by Kaplan-Meier analysis of a large cohort of protein Sdeficient families. In support of our findings, we present a detailed characterization of type I and type III protein S-deficient plasma based on the measurement of coagulation factor levels and ad hoc thrombin generation assays.

\section{MATERIALS AND METHODS}

\section{Study population}

Thirty families with type I and/or type III protein S deficiencies (242 individuals), identified at Padua University Hospital (Italy) between 1996 and 2002, were included in the Kaplan-Meier analysis. Families were ascertained via a proband who underwent thrombophilia screening after a first episode of venous (deep-vein thrombosis, pulmonary embolism or superficial-vein thrombosis) or arterial thrombosis (myocardial infarction or stroke). Family members of each proband were invited to participate, and information on thrombosis history and age at onset of the first thrombotic event was recorded for each participant. Criteria for diagnosing venous thromboembolism have been previously reported. ${ }^{25,26}$ Protein $S$ deficiency was defined on the basis of free protein $S$ levels, ${ }^{27,28}$ applying a cut-off of $65 \%$. The type of deficiency was assigned according to total protein $\mathrm{S}$ levels, using a cut-off of $70 \%$ (irrespective of age and sex). Cut-offs were based on the variation of total and free protein $\mathrm{S}$ levels in a population of 140 healthy individuals.

Functional studies were performed in 23 of the above-mentioned 30 families. Blood samples were collected from probands and consenting family members for a total of 151 subjects. Patients on oral anticoagulant therapy $(n=13)$ and women taking oral contraceptives 
$(n=3)$ or hormone replacement therapy $(n=3)$ at the time of blood collection were subsequently excluded, leaving 132 individuals available for study (Table 1). All participants provided informed consent to the study, which was carried out in accordance with the Helsinki protocol.

\section{Blood collection and plasma preparation}

Venous blood was drawn in $0.129 \mathrm{M}$ sodium citrate $(1: 9 \mathrm{vol} / \mathrm{vol})$ and platelet-poor plasma was prepared by centrifugation at $2000 \times \mathrm{g}$ for $10 \mathrm{~min}$. Plasma was aliquoted, snapfrozen and stored at $-80^{\circ} \mathrm{C}$ until use. Buffy coats were stored at $-20^{\circ} \mathrm{C}$ for later DNA isolation.

\section{Genetic analysis}

Buffy coats were available for 110 of the 132 eligible participants. Genomic DNA was extracted using the Wizard ${ }^{\circ}$ Genomic DNA Purification kit (Promega, Madison WI, USA). PROS1 mutation screening was performed by PCR-mediated amplification of each exon (including splicing junctions) and $>400$ bp of the promoter region ${ }^{29}$ followed by direct sequencing. PCR primers and conditions (available on request) were chosen such as to avoid co-amplification of the highly homologous protein S pseudogene. Selective amplification of PROS1 was verified by restriction analysis of the PCR products prior to sequencing. Whenever a PROS1 mutation was identified, all family members were tested for carriership of that mutation by high-resolution agarose gel electrophoresis, restriction analysis or direct sequencing, as detailed in Table 2. The PROS1 Heerlen genotype was determined by Rsa Irestriction analysis of exon 13.

In families without apparent mutation, the possibility of a large deletion was verified by PROS1 haplotyping and segregation analysis. Haplotypes were constructed with three common intragenic polymorphisms: +54 T/C in intron 11 (PIPS1, rs8178649), ${ }^{30} 2147 \mathrm{~A} / \mathrm{G}$ in exon 15 (Pro ${ }^{626}$ dimorphism, rs6123) ${ }^{31}$ and $2697 \mathrm{C} / \mathrm{A}$ in the $3^{\prime}$-UTR (PEPS2, rs9681204). ${ }^{30}$ Genotyping was performed by restriction analysis with HpyCH4 III, BstX I and Ava II (New England BioLabs, Ipswich MA, USA), respectively.

Carriership of the FV Leiden mutation was determined as previously described. ${ }^{32}$

\section{Measurement of plasma factor levels}

In house ELISAs were used to measure the plasma antigen levels of total, ${ }^{33}$ free $^{34}$ and C4BP-bound protein $S^{8}{ }^{8}$ as well as full-length TFPI (Maurissen et al., in preparation). Prothrombin levels were determined with a chromogenic assay, as previously described. ${ }^{32}$ 
Antithrombin activity levels were determined using the Coamatic $\AA$ Antithrombin kit (Chromogenix, Mölndal, Sweden). The levels of all factors were expressed as percentage of normal pooled plasma.

\section{Thrombin generation measurements}

Thrombin generation was measured with the Calibrated Automated Thrombogram (CAT) method, ${ }^{35}$ essentially as described. ${ }^{32}$ Briefly, coagulation was initiated with tissue factor (TF, Innovin', DADE-Behring, Marburg, Germany), synthetic phospholipid vesicles (DOPS/DOPC/DOPE, $20 / 60 / 20 \mathrm{~mol} / \mathrm{mol} / \mathrm{mol}$ ) and $\mathrm{CaCl}_{2}$, and thrombin activity in plasma was monitored continuously with fluorogenic substrate Z-Gly-Gly-Arg-AMC (BACHEM, Bubendorf, Switzerland). Fluorescence was read in a Fluoroskan Ascent reader (Thermo Labsystems, Helsinki, Finland) and thrombin generation curves were calculated using the Thrombinoscope ${ }^{\mathrm{TM}}$ software (Thrombinoscope, Maastricht, The Netherlands).

To probe the activity of the APC/protein S system, thrombin generation was initiated with $6.8 \mathrm{pM}$ TF and $30 \mu \mathrm{M}$ phospholipids in the absence and presence of $5 \mathrm{nM}$ human APC (Kordia Life Sciences, Leiden, The Netherlands). The outcome of the assay was expressed as the ratio of the endogenous thrombin potentials (ETPs) obtained in the presence and absence of APC, and normalized against the ETP ratio of normal pooled plasma measured in parallel (normalized APC-sensitivity ratio, nAPCsr). Since protein $S$ is a major determinant of this assay, $^{36}$ the nAPCsr is an indirect measure of the APC-dependent activity of protein S. The nAPCsr varies between 0 and 10 and increases as the APC-cofactor activity of protein $\mathrm{S}$ decreases.

To quantify the activity of the TFPI/protein S system, thrombin generation was initiated with $1.36 \mathrm{pM}$ TF and $30 \mu \mathrm{M}$ phospholipids in the absence and presence of neutralizing antibodies against protein $\mathrm{S}(270 \mu \mathrm{g} / \mathrm{ml}$ polyclonal IgG; DAKO, Glostrup, Denmark) or TFPI (64 $\mathrm{gg} / \mathrm{ml}$ monoclonal IgG1; Sanquin, Amsterdam, The Netherlands). To exclude any contribution of the APC-dependent activity of protein S, these measurements were conducted in the presence of $100 \mu \mathrm{g} / \mathrm{ml}$ anti-protein C polyclonal antibodies (DAKO). Moreover, corn trypsin inhibitor (CTI, Hematologic Technologies, Essex Junction VT, USA) was added to a final concentration of $30 \mu \mathrm{g} / \mathrm{ml}$ to prevent contact activation. At the low TF concentration used in this assay, the height of the thrombin peak proved to be a more sensitive indicator of thrombin generation than the ETP and was therefore used as output parameter. The ratio of the thrombin generation peaks obtained in the absence and presence of anti-protein $S$ antibody (PS-ratio) is a measure of the TFPI-cofactor activity of protein S, while the ratio of the 
thrombin generation peaks obtained in the absence and presence of anti-TFPI antibody (TFPIratio) is a measure of the activity of the TFPI/protein S system as a whole. Both ratios vary between 0 and 1 and increase as the TFPI-cofactor activity of protein $\mathrm{S}$ decreases.

\section{Statistics}

Kaplan-Meier analysis. Thrombosis-free survival was analyzed with the Kaplan-Meier method. The age at onset of the first thrombotic event for symptomatic individuals and the age at the time of inclusion in the study for asymptomatic subjects were used to evaluate the thrombosis-free survival time. Thrombosis-free survival was compared between normal $(n=112)$, type I protein S-deficient $(n=73)$ and type III protein S-deficient $(n=57)$ individuals, with probands included or excluded, and in probands only. The analysis was done including all patients or only patients whose first thrombotic event had been deep-vein thrombosis and/or pulmonary embolism. Differences between the curves were assessed with the log-rank test.

General statistics. Data are reported as mean \pm standard deviation (SD), unless otherwise indicated. Plasma factor levels were compared between groups with the Student's $t$ test. Thrombin generation parameters were compared with the non-parametric MannWhitney-Wilcoxon test $(U)$ due to their non-normal distribution in some population subgroups. Correlations were expressed as Pearson coefficients ( $r$ ). The determinants of thrombin generation parameters were identified by multiple regression analysis and their effects were expressed as unstandardized regression coefficients (B). Statistical analyses were performed with SPSS 14.0 for Windows (SPSS, Chicago IL, USA). 


\section{RESULTS}

\section{Clinical evaluation}

Two-hundred-forty-two individuals from 30 families with type I and/or type III protein S deficiency were investigated. Of the 30 probands, 18 presented with type I deficiency and 12 with type III deficiency (age at inclusion $46.8 \pm 11.9$ vs. $52.5 \pm 15.1$ years, $p=n . s$.). The age at the first thrombotic event was $30 \pm 10.4$ years (median, 28.5 years) for probands with type I deficiency and $36.6 \pm 15.5$ years (median, 33.5 years) for probands with type III deficiency, respectively ( $p=$ n.s.). Out of 212 family members, 112 had normal protein $\mathrm{S}$ levels and 100 were protein S-deficient (55 type I and 45 type III). The age of family members at the time of inclusion was $46.9 \pm 20.2$ years for normal individuals, $48.5 \pm 19.8$ years for type I deficient individuals and $56.9 \pm 15.9$ years for type III deficient individuals. Type III deficient subjects were significantly older than type I deficient and normal subjects $(p=0.037)$. At the time of inclusion, thrombotic events in family members had occurred in 17/55 (30.9\%) type I deficient subjects, $19 / 45(42.2 \%)$ type III deficient subjects and in $7 / 112$ (6.2\%) normal subjects. The mean age at the first thrombotic event was $40.6 \pm 16.7$ years (median, 42 years) in type I deficient individuals, $42.6 \pm 16.7$ years (median, 45 years) in type III deficient individuals and $47 \pm 23.4$ years (median, 41 years) in normal individuals ( $p=n . s$.$) .$
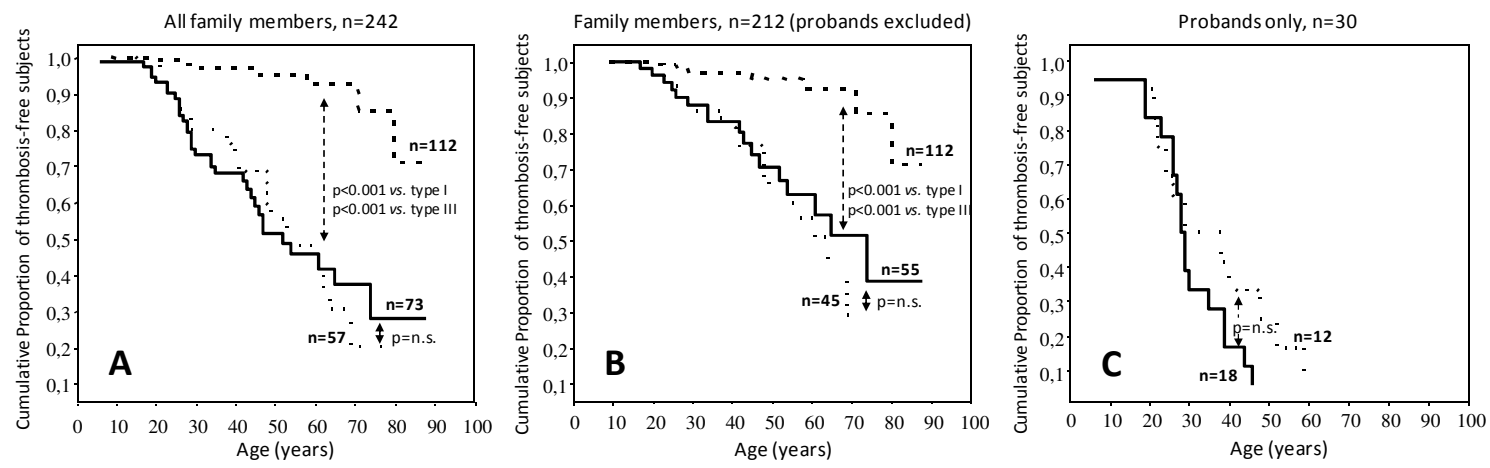

Figure 4.1: Thrombosis-free survival analysis of protein S-deficient individuals. Kaplan-Meier analysis of A) the whole study cohort (probands and family members); B) family members after exclusion of probands; and C) probands only. Dashed line represents normal individuals, solid and dotted lines represent type I and type III protein S-deficient individuals, respectively. Differences between the curves were evaluated with the log-rank test.

To evaluate the risk of thrombosis associated with protein S deficiency, Kaplan-Meier analysis was performed. As expected, the cumulative proportion of thrombosis-free 
individuals was higher $(\mathrm{p}<0.001)$ in the normal group than in the protein S-deficient group (Figure 4.1A,B). However, no significant difference in thrombosis-free survival was observed between type I and type III protein S-deficient individuals in the whole cohort (probands and family members, Figure 4.1A), nor after exclusion of probands (Figure 4.1B) or in probands only (Figure 4.1C). Results did not change when survival analysis was restricted to patients whose first thrombotic event had been deep-vein thrombosis and/or pulmonary embolism or when males and females were analyzed separately (data not shown).

\section{Laboratory evaluation: characteristics of the study population}

Plasma factor levels and thrombin generation were measured in a random subset of the population used for Kaplan-Meier analysis (23 families: 21 with type I or mixed type I/III deficiency and 2 with pure type III deficiency). After excluding patients taking oral anticoagulants and women on hormonal therapy, 132 individuals (53 normal, 59 type I deficient and 20 type III deficient) were available for plasma phenotyping (Table 4.1).

Table 4.1. Demographic characteristics of the study population

\begin{tabular}{|c|c|c|c|c|}
\hline & N & $\begin{array}{c}\text { Sex } \\
\text { (M/F) }\end{array}$ & $\begin{array}{c}\text { Age } \\
\text { (years) }\end{array}$ & $\begin{array}{c}\text { VTE } \\
\text { N (\%) }\end{array}$ \\
\hline Normal & 53 & $31 / 22$ & $38.4 \pm 20.0$ & $4(7.5 \%)$ \\
\hline PS-deficient & 79 & $31 / 48$ & $42.7 \pm 19.0$ & $24(30.4 \%)$ \\
\hline Type I & 59 & $22 / 37$ & $38.3 \pm 17.9$ & $18(30.5 \%)$ \\
\hline Type III & 20 & $9 / 11$ & $56.0 \pm 16.0$ & $6(30.0 \%)$ \\
\hline
\end{tabular}

PS, protein S; VTE, venous thromboembolism

The female gender was over-represented among protein S-deficient subjects, especially in the type I subgroup ( $p=0.020$ vs. normal subjects). Mean age was not different between normal and protein S-deficient individuals, but type III deficient subjects were significantly older than type I deficient subjects (56.0 vs. 38.3 years, $p<0.001)$. The protein $S-$ deficient group was enriched in thrombotic patients ( $p=0.007$ vs. normal subjects), but the percentage of patients was not different between the type I and type III subgroups. 
Genotyping for the FV Leiden mutation identified 8 heterozygous carriers in three different families.

\section{PROS1 mutation screening}

Due to the availability of genomic DNA from at least one protein S-deficient family member, PROS1 mutation screening was possible in 20 of the 23 families. By sequencing the coding region including splicing junctions and the proximal promoter, a PROS1 mutation was identified in 14 families (Table 4.2). When the genetic screening was extended to family members, the respective mutation was identified in 51/53 (96\%) individuals classified as protein S-deficient on the basis of protein S levels and in 2/26 (7.7\%) of individuals classified as normal. The Heerlen mutation was present in 3 individuals, all belonging to the same family (Table 4.2). All mutations were in the heterozygous state. In all mixed type $1 /$ III families (except in the family with the Heerlen mutation), the same mutation accounted for type I as well as type III deficient members.

In the six families where no mutation was detected, 3-point PROS1 haplotype- and segregation analysis was performed to check for the presence of large intragenic deletions. Based on the apparent co-segregation of the protein S-deficient phenotype with two different PROS1 haplotypes (CAC and TAA) in different family members, a PROS1 deletion could be ascertained in one family. The remaining families were uninformative.

\section{Plasma factor levels}

Plasma levels of protein S (total, free and C4BP-bound), prothrombin, antithrombin and full-length TFPI were measured in all subjects and compared between groups (Figure 4.2). Total protein S levels (Figure 4.2A) were higher in type III deficient individuals $(79.0 \pm 6.3 \%)$ than in type I deficient individuals $(52.9 \pm 9.0 \%, p<0.001)$, but still significantly lower than in normal individuals $(94.3 \pm 17.2 \%, p<0.001)$. Similarly, free protein $S$ levels (Figure $4.2 B$ ) were lower in type III deficient individuals $(54.7 \pm 6.6 \%)$ than in normal individuals $(89.5 \pm 15.4 \%$, $p<0.001)$, but still significantly higher than in type I deficient individuals $(40.4 \pm 9.6 \%, p<0.001)$. C4BP-bound protein S levels (Figure 4.2C) were not different between normal (119.4 $\pm 37.3 \%)$ and type III deficient individuals (111.2 $224.5 \%)$, but they were significantly reduced in type I deficient individuals ( $91.7 \pm 31.5 \%, p=0.007$ vs. type III). Prothrombin levels (Figure 4.2D) did 


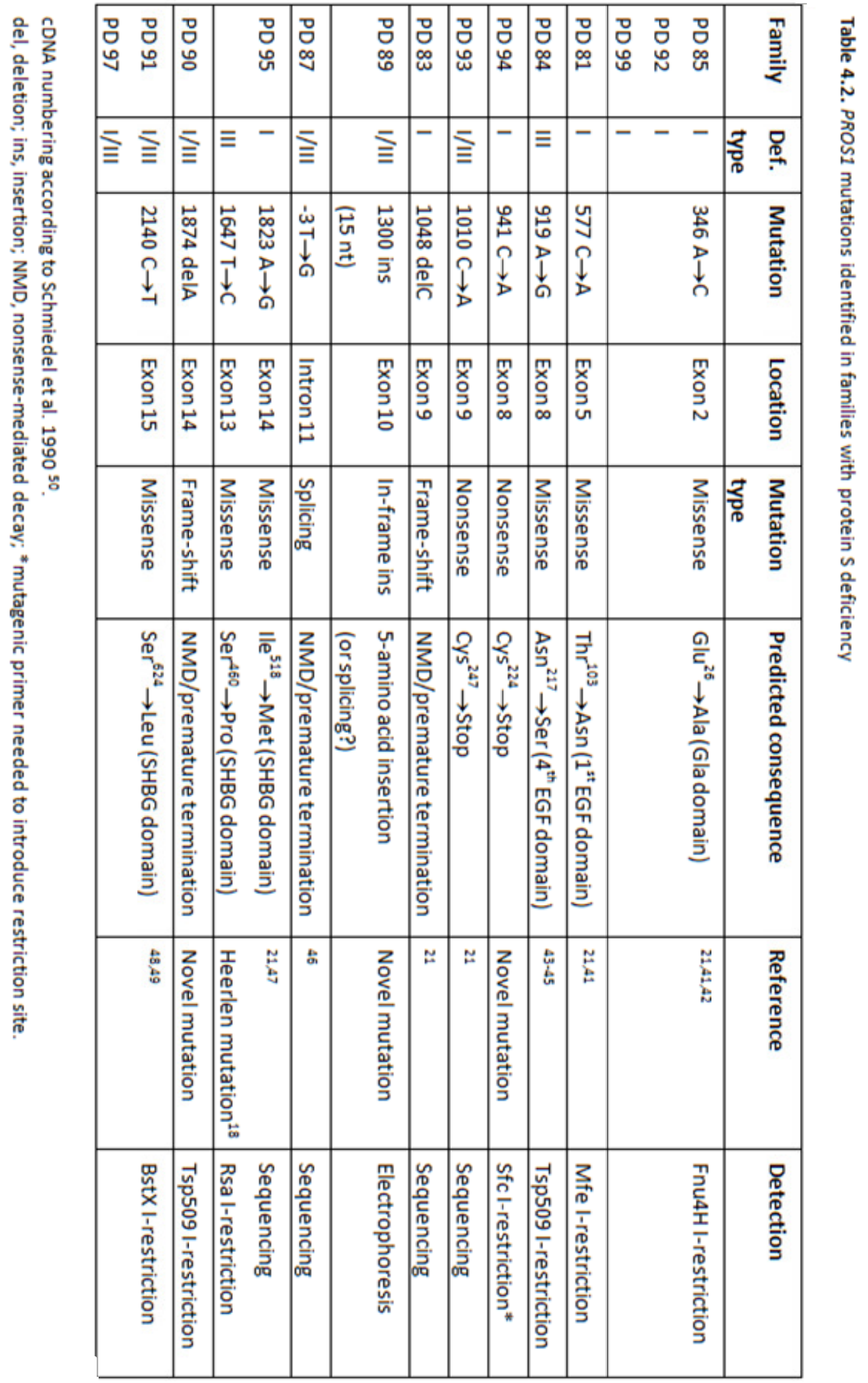


not differ between normal $(92.5 \pm 18.7 \%)$ and type I deficient individuals $(88.8 \pm 12.0 \%)$, but they were significantly elevated in type III deficient individuals $(104.1 \pm 16.0 \%, p=0.011$ and $\mathrm{p}=0.001$ vs. normal and type I deficient individuals, respectively). Antithrombin levels (Figure 4.2E) were similar in all three groups. Finally, full-length TFPI levels (Figure 4.2F) were not different between normal (122.9 $\pm 47.7 \%)$ and type III deficient individuals $(121.3 \pm 31.4 \%)$, but they were significantly reduced in type I deficient individuals $(76.9 \pm 32.5 \%, p<0.001)$. All intergroup differences in plasma factor levels persisted after correction for age and sex.
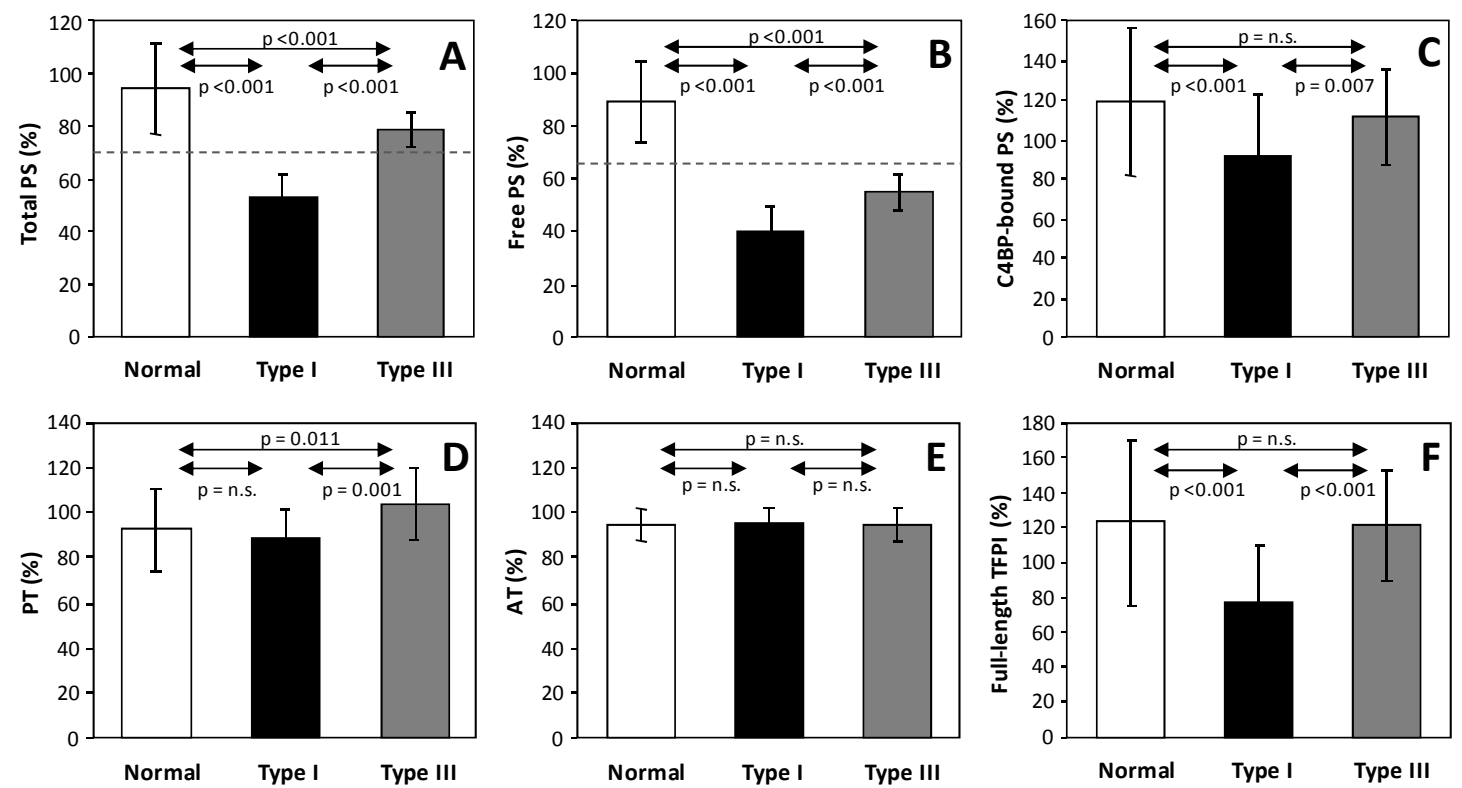

Figure 4.2: Plasma levels of coagulation factors and inhibitors. Mean plasma levels of total protein $S(A)$, free protein $S(B), C 4 B P$-bound protein $S(C)$, prothrombin $(D)$, antithrombin (E) and fulllength TFPI (F) in normal individuals (white bars) and in individuals with type I (black bars) or type III (grey bars) protein $\mathrm{S}$ deficiency. Error bars represent standard deviations. The dotted lines mark the cut-offs for total and free protein $S$ levels. Groups were compared with the Student's $t$ test.

The plasma levels of coagulation factors and inhibitors were highly correlated in the study population. The strongest correlations were observed between total, free and bound protein $S$ (total/free: $r=0.885$; total/bound: $r=0.413$; free/bound: $r=0.434 ; p<0.001$ for all three correlations), total protein $S$ and full-length TFPI $(r=0.607, p<0.001)$, and total protein $S$ and prothrombin $(r=0.371, p<0.001)$. 


\section{APC-cofactor activity of protein $S$}

To quantify the activity of the APC/protein S system, thrombin generation was measured at $6.8 \mathrm{pM}$ TF in the absence and presence of APC, and the nAPCsr was calculated. Since FV Leiden strongly influences this assay, FV Leiden carriers were excluded from the analysis.

Despite a large inter-individual variability, on average thrombin generation started earlier and was higher in protein S-deficient plasma than in normal plasma, both in the absence and presence of APC (Table 4.3, Supplemental Material). In the absence of APC (Figure 4.3A), there was no difference between the ETPs of normal and type I deficient individuals, but type III deficient individuals had significantly higher ETP values ( $p \leq 0.001)$. In the presence of APC (Figure 4.3B), the ETPs of type I and type III deficient individuals were similar and markedly higher than those of normal individuals $(p<0.001)$. As a consequence, the nAPCsr (Figure 4.3C), was highest in type I deficient plasma, slightly lower in type III deficient plasma $(p=0.057)$ and much lower in normal plasma $(p<0.001)$. Thrombotic patients had a higher nAPCsr than healthy relatives, both in the type I $(6.36 \pm 1.38 v s .5 .77 \pm 1.37)$ and in the type III $(5.59 \pm 2.04$ vs. $4.97 \pm 1.83)$ deficiency groups, but these differences did not reach statistical significance.
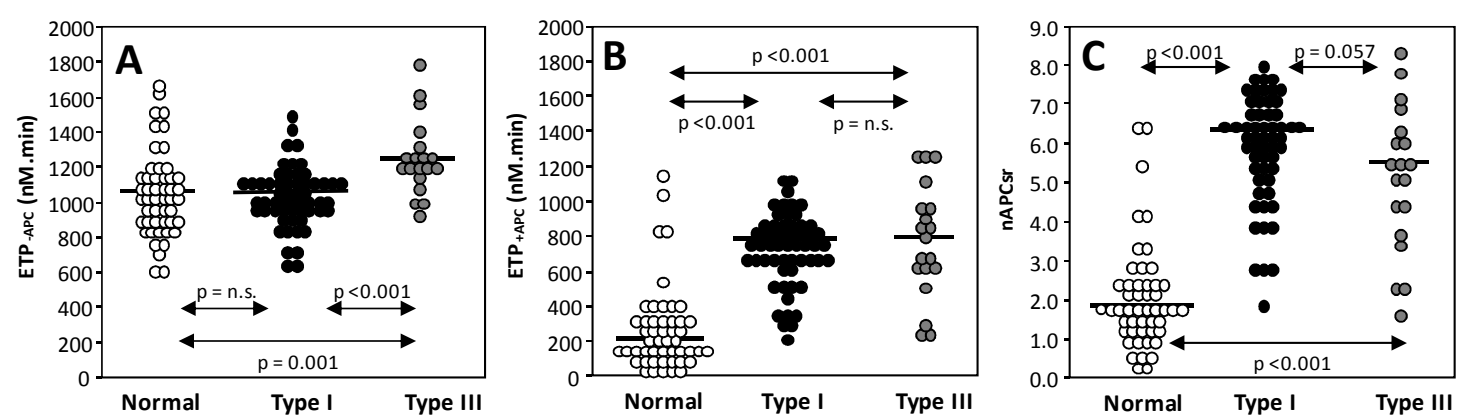

Figure 4.3: Thrombin generation in the absence and presence of APC. Thrombin generation was measured at $6.8 \mathrm{pM}$ TF in the absence and presence of $5 \mathrm{nM} \mathrm{APC}$. FV Leiden carriers were excluded. A) ETPs measured in the absence of APC; B) ETPs measured in the presence of APC; C) nAPCsr. White circles, normal individuals; black circles, individuals with type I protein $\mathrm{S}$ deficiency; grey circles, individuals with type III protein $S$ deficiency. Lines represent the medians of the respective distributions. Groups were compared with the Mann-Whitney-Wilcoxon test.

To interpret this results, the effects of age, sex and the levels of prothrombin, antithrombin, total and free protein S and full-length TFPI on the ETP measured in the absence and presence of APC were determined by multiple regression analysis in the normal group. 


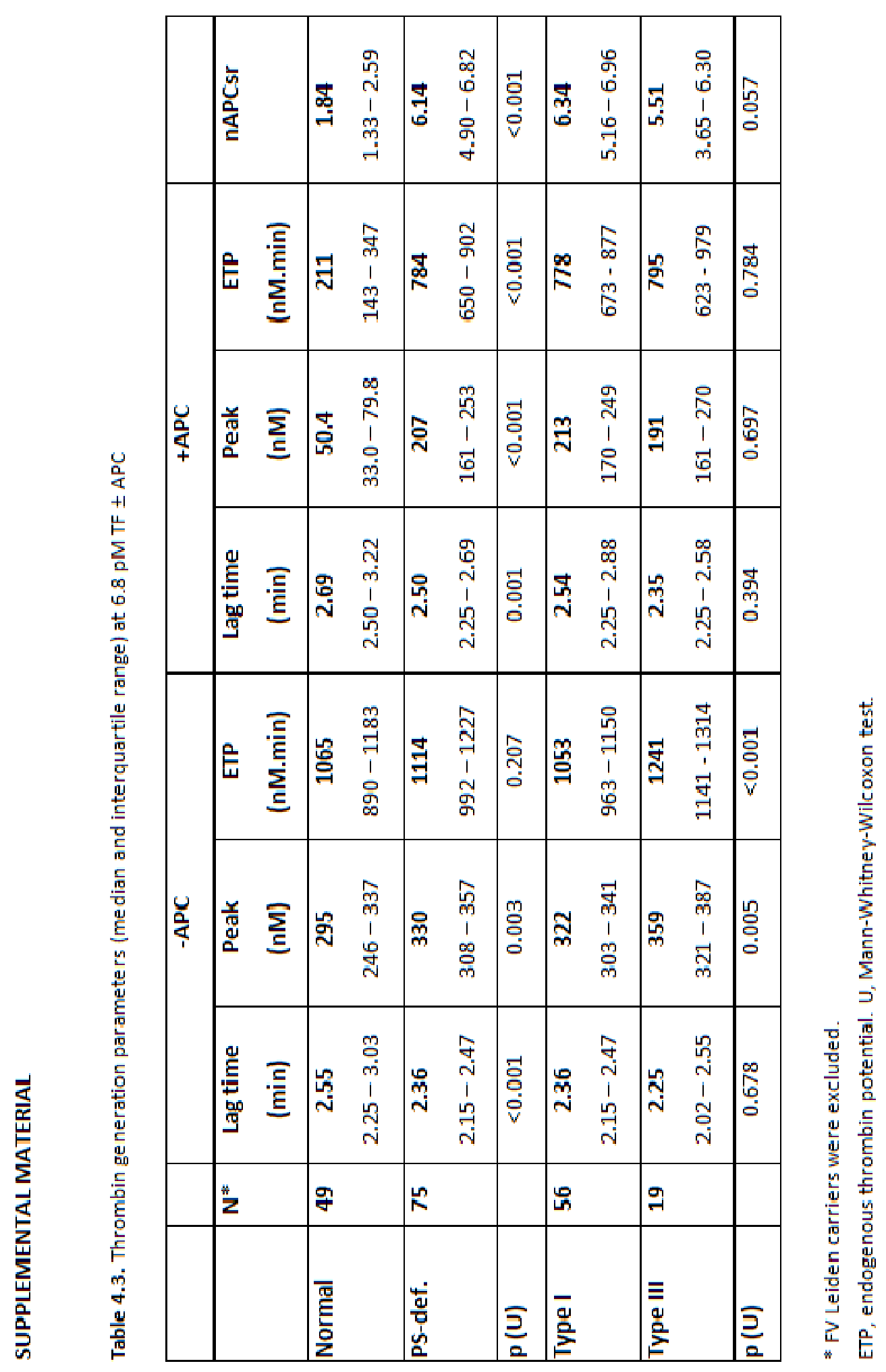


Age ( $B=4.4 \mathrm{nM} . \mathrm{min} /$ year, $p=0.001)$ and prothrombin level $(B=129.3 \mathrm{nM} . \mathrm{min} / 10 \%, p<0.001)$ were both found to be strong determinants of the ETP-APC, which accounts for the higher ETP. APC in type III deficient individuals. Similarly, age ( $B=6.4 \mathrm{nM} . \mathrm{min} /$ year, $p<0.001)$ and prothrombin $(B=89.4 \mathrm{nM} . \mathrm{min} / 10 \%, \mathrm{p}<0.001)$ were positive determinants of the $\mathrm{ETP}_{+\mathrm{APC}}$, while free protein $S(B=-58.6 n M . m i n / 10 \%, p=0.028)$ and TFPI ( $B=-16.5 n M . m i n / 10 \%, p=0.009)$ were negative determinants, explaining the absence of a difference in ETP $_{+A P C}$ between type I and type III deficient individuals. In fact, although type III deficient individuals would be expected to have a lower ETP + APC than type I because of their higher free protein S and TFPI levels, their concomitant higher age and prothrombin level tend to abolish this difference, making the $\mathrm{ETP}_{+\mathrm{APC}}$ similar in the two groups.

\section{TFPI-cofactor activity of protein S}

The activity of the TFPI/protein S system was quantified by measuring thrombin generation at $1.36 \mathrm{pM}$ TF in the absence and presence of neutralizing antibodies against protein S ( $\alpha \mathrm{PS}$ ) or TFPI ( $\alpha$ TFPI) and by calculating the PS- and TFPI-ratios. Also in this case FV Leiden carriers were excluded.

Thrombin generation in the absence of antibodies was again faster and higher in protein S-deficient plasma than in normal plasma (Table 4.4, Supplemental Material). However, this difference largely disappeared in the presence of antibodies, only the lag time remaining slightly but significantly shorter in protein S-deficient plasma (Table 4.4, Supplemental Material). Also in this test, a large inter-individual variability was observed. In the absence of antibodies (Figure 4.4A), the peak height was virtually identical in type I and type III deficient individuals, and higher than in normal individuals $(p \leq 0.011)$. Addition of $\alpha$ PS, and even more so addition of $\alpha$ TFPI, caused an increase in thrombin generation, due to the partial ( $\alpha \mathrm{PS}$ ) or complete ( $\alpha \mathrm{TFPI}$ ) inhibition of the TFPI/protein S system. In the presence of aPS (Figure 4.4B), the peak height was similar between normal and type III deficient individuals, while type I deficient individuals had slightly higher thrombin peaks, possibly due to their lower TFPI levels. In the presence of the $\alpha$ TFPI antibody (Figure 4.4C), normal and type I deficient plasmas yielded similar peak heights, which however were lower than in type III deficient plasma $(p=0.022$ and $p=0.010$, respectively). The PS-ratio (Figure 4.4D) and TFPI-ratio (Figure 4.4E) increased progressively from normal to type III and type I deficient plasma. However, the difference between type I and III deficient individuals was only significant for the TFPI-ratio $(p=0.034)$. 


\begin{tabular}{|c|c|c|c|c|c|c|c|}
\hline & 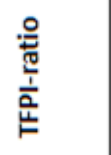 & 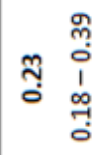 & 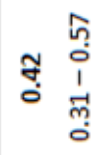 & ठั. & $\begin{array}{ll}\stackrel{8}{0} \\
\stackrel{0}{0} \\
\stackrel{1}{1} \\
0 \\
0 \\
0 \\
0\end{array}$ & 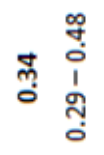 & 范 \\
\hline & $\begin{array}{l}\stackrel{\circ}{\frac{0}{\omega}} \\
\stackrel{\omega}{\alpha}\end{array}$ & 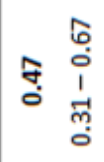 & 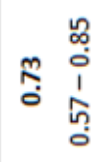 & $\begin{array}{l}-1 \\
\text { ò } \\
\text { v }\end{array}$ & 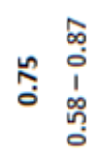 & 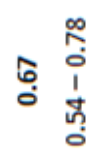 & ન్ \\
\hline \multirow{3}{*}{ 产 } & 毵 & 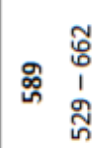 & 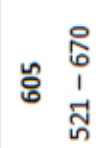 & 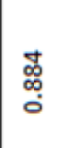 & 总 & ఫ్ర & 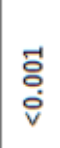 \\
\hline & 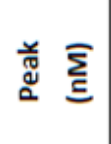 & 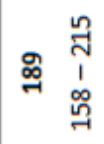 & 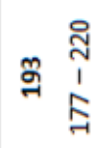 & 髈 & 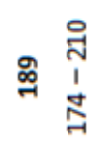 & 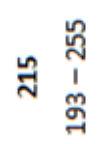 & 웅 \\
\hline & 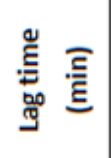 & 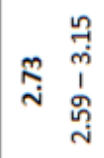 & 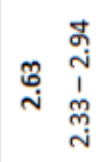 & $\stackrel{\infty}{0}$ & 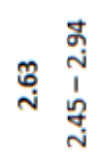 & 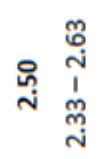 & స્తి \\
\hline \multirow{3}{*}{ 气ิ } & E) & 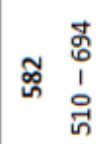 & \begin{tabular}{ll} 
& \multicolumn{2}{c}{} \\
gे & 1 \\
जี
\end{tabular} & న్తి & 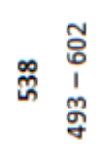 & ڤొ & ڤั̣ \\
\hline & 曾 $\bar{\Xi}$ & $\approx$ & $\exists \frac{\stackrel{n}{1}}{\frac{1}{\delta}}$ & 売 & ‡ & $\exists \stackrel{\substack{\stackrel{1}{1} \\
\hat{\delta}}}{\stackrel{\infty}{1}}$ & $\begin{array}{l}\mathscr{0} \\
0 \\
0\end{array}$ \\
\hline & 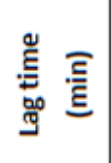 & 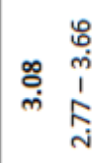 & 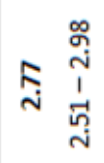 & o: & 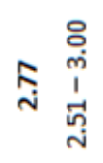 & 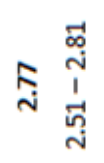 & 芯 \\
\hline \multirow{5}{*}{ 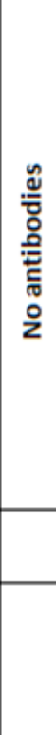 } & 墩 & 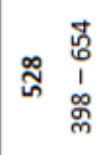 & 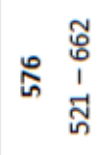 & 웅 & 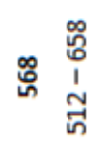 & ป & 응 \\
\hline & 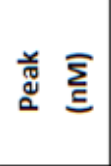 & 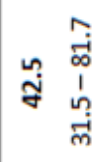 & 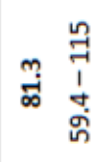 & ठั & 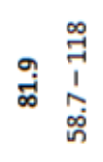 & 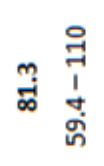 & 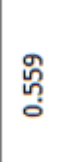 \\
\hline & 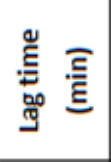 & 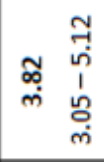 & 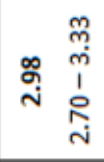 & ठั & 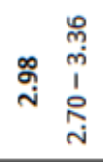 & 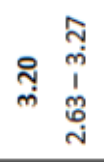 & $\underset{\infty}{\infty}$ \\
\hline & $z$ & g & $\stackrel{n}{\kappa}$ & & in & 요 & \\
\hline & & $\begin{array}{l}\overline{\widetilde{g}} \\
\text { हे } \\
\text { z }\end{array}$ & 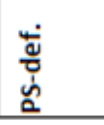 & $\sum_{a}$ & $\overline{\grave{a}}$ & 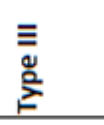 & $\bar{\Omega}_{a}$ \\
\hline
\end{tabular}



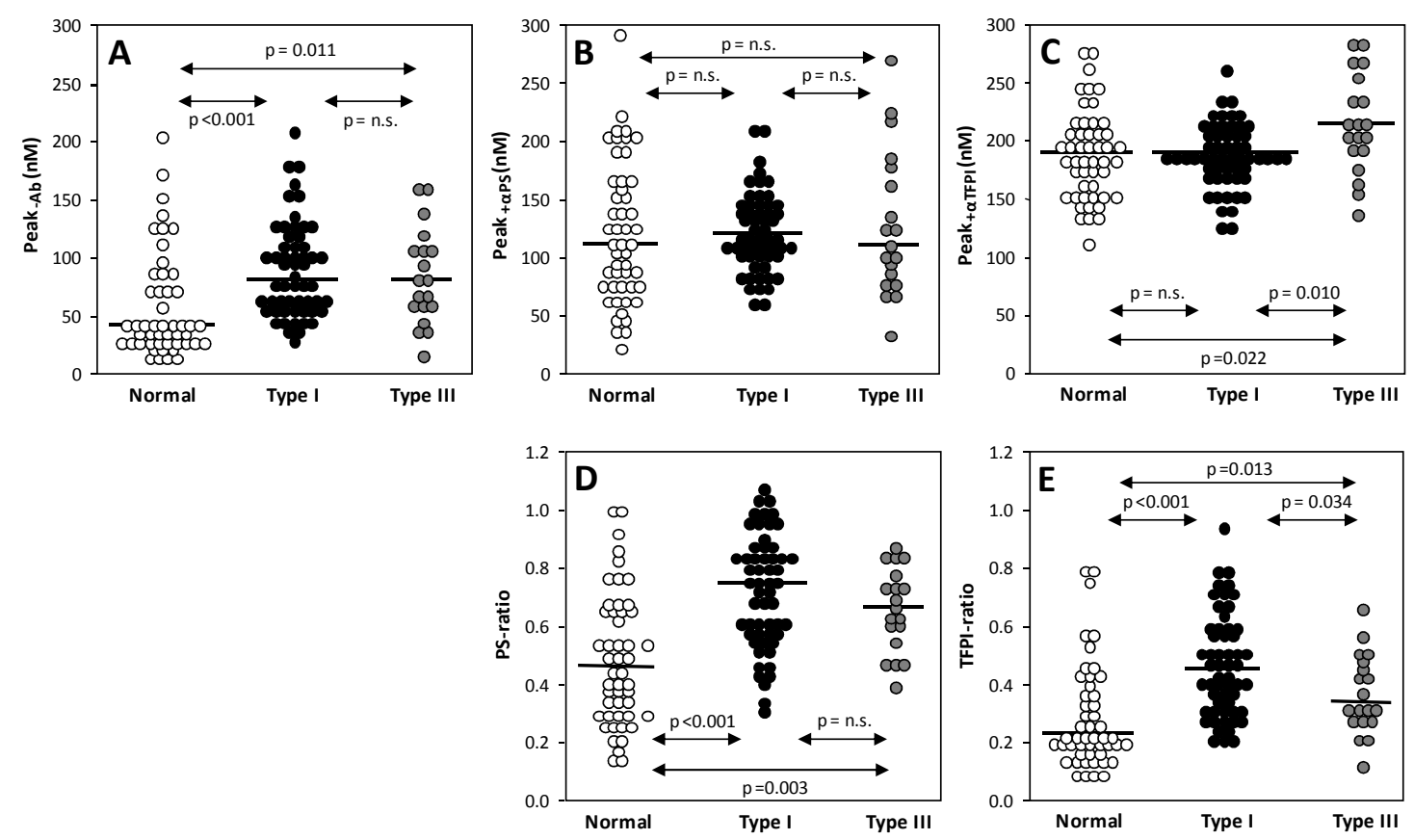

Figure 4.4: Thrombin generation in the absence and presence of $\alpha$ PS or $\alpha$ TFPI. Thrombin generation was measured at $1.36 \mathrm{pM}$ TF in the absence and presence of antibodies against protein $\mathrm{S}$ or TFPI. FV Leiden carriers were excluded. A) Thrombin peaks measured in the absence of antibodies; B) thrombin peaks measured in the presence of $\alpha \mathrm{PS} ; \mathrm{C}$ ) thrombin peaks measured in the presence of aTFPI; D) PS-ratio; and E) TFPI-ratio. White circles, normal individuals; black circles, individuals with type I protein S deficiency; grey circles, individuals with type III protein $\mathrm{S}$ deficiency. Lines represent the medians of the respective distributions. Groups were compared with the Mann-Whitney-Wilcoxon test.

Multiple regression analysis revealed that the peak height in the absence of antibodies was dependent not only on free protein $S(B=-13.4 n M / 10 \%, p=0.021)$ and TFPI $(B=-5.7 n M / 10 \%, p<0.001)$, but also on age $(B=0.8 n M / y e a r, p=0.035)$ and prothrombin $(B=8.3$ $\mathrm{nM} / 10 \%, \mathrm{p}=0.023)$, thereby accounting for the equally elevated peaks in type I and type III deficient individuals. Similarly, the higher peak $_{+\alpha p s}$ of type I deficient individuals was attributable their lower TFPI levels $(B=-6.8 n M / 10 \%, p=0.002)$, while the higher age $(B=1.1$ $n M /$ year, $p<0.001)$ and prothrombin level $(B=17.5 \mathrm{nM} / 10 \%, p<0.001)$ of type III deficient individuals were again responsible for their elevated peak ${ }_{+\alpha T F P 1}$.

\section{Relationship between nAPCSr and TFPI-ratio}

The nAPCsr and the TFPI-ratio reflect the activities of the APC/protein $S$ and $\mathrm{TFPI} /$ protein S systems, respectively. Both were elevated in protein S-deficient individuals, especially in those with type I deficiency, in line with the respective protein S levels.

Multiple regression analysis showed that free protein S and full-length TFPI levels were major determinants of both the nAPCsr $(B=-0.37 / 10 \%$ protein $S, p<0.024 ; B=-0.10 / 10 \%$ 
TFPI, $\mathrm{p}=0.007)$ and the TFPI-ratio $(\mathrm{B}=-0.06 / 10 \%$ protein $\mathrm{S}, \mathrm{p}=0.011 ; \mathrm{B}=-0.02 / 10 \%$ TFPI, $p<0.001)$. In addition, the nAPCsr was also dependent on age $(B=0.04 /$ year, $p=0.001)$ and prothrombin levels $(B=0.37 / 10 \%$ prothrombin, $p=0.001)$. Accordingly, the $n A P C s r$ and the TFPI-ratio were highly correlated in the normal $(r=0.663, p<0.001)$ and type I deficiency $(r=0.510, p<0.001)$ groups, but not in the type III deficiency group $(r=0.311, p=n . s$.$) (Figure$ 4.5). However, after removal of a single outlier (Figure 4.5, arrow), the correlation between nAPCsr and TFPI-ratio was also apparent in type III deficient individuals ( $r=0.501, p=0.034)$.

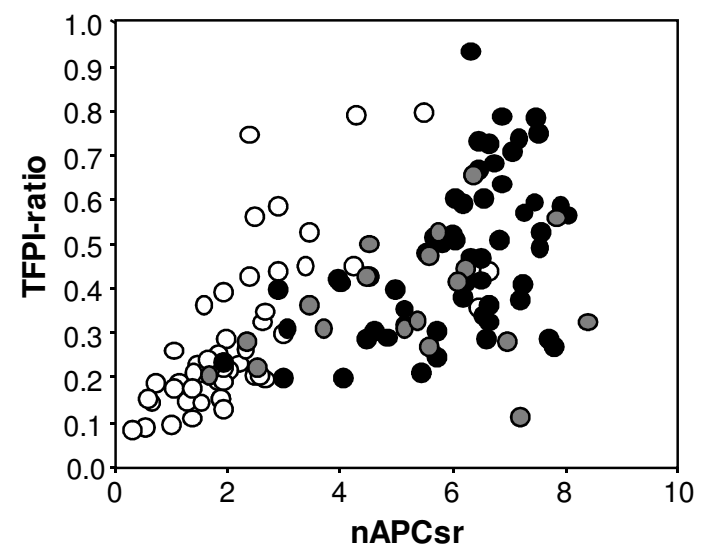

Figure 4.5: Correlation between the nAPCsr and the TFPI-ratio. The nAPCsr and the TFPI-ratio were determined as described under Methods. FV Leiden carriers were excluded. White circles, normal individuals; black circles, type I protein S-deficient individuals; grey circles, type III protein S-deficient individuals. The arrow indicates an outlier with a high nAPCsr and a low TFPI-ratio. 


\section{DISCUSSION}

Although the thrombotic predisposition associated with protein $\mathrm{S}$ deficiency was recognized as early as $1984,{ }^{10,11}$ accurate risk estimates have been hindered by the difficulty of correctly diagnosing protein S deficiency. While type I protein S deficiency is generally considered a risk factor for venous thrombosis, conflicting results have been reported for type III deficiency, ${ }^{22-24}$ possibly due to the fact that type III protein $S$ deficiency is a heterogeneous category comprising individuals from pure type III and mixed type I/III deficient families, as well as individuals with acquired (transient) protein S deficiency.

In the present study we have re-evaluated the thrombosis risk associated with type I and type III protein S-deficiencies by Kaplan-Meier analysis of a large cohort of protein Sdeficient families. Our data indicate that inherited type III protein S deficiency is a risk factor for venous thrombosis and that it confers a similar risk as type I protein $\mathrm{S}$ deficiency (Figure 4.1). In particular, although type III deficient individuals were older than type I deficient individuals and advancing age is also a risk factor for thrombosis, the age at onset of thrombosis was not different between the two groups.

To account for this finding, genetic and functional studies were performed in 23 families with type I and/or type III protein S deficiency (Table 4.1). Genetic screening was possible in 20 families and yielded 11 PROS1 mutations (3 novel) in 14 families (Table 4.2). Moreover, a (partial) PROS1 deletion was present in at least one family. Our mutation detection rate $(15 / 20=75 \%)$ and mutation spectrum ( 5 missense and 3 nonsense substitutions, 1 splicing mutation, 3 small deletions/insertions and 1 large deletion) are in agreement with literature data. ${ }^{12}$ When family members were tested for carriership of the mutation found in the respective proband, an excellent co-segregation between PROS1 genotype and protein $\mathrm{S}$ levels was observed. This not only confirms the causal role of the identified mutations, but also indicates that the free protein $S$ level cut-off used to define protein $S$ deficiency is appropriate and reliable. ${ }^{28}$ Remarkably, the only two mutation-positive individuals who were classified as normal on the basis of their protein $S$ levels carried the $\mathrm{Thr}^{103} \rightarrow$ Asn mutation, which has been associated with qualitative (type II) protein S deficiency in another study. ${ }^{37}$ However, their nAPCsr and TFPI-ratio were within the normal range.

For functional studies, the population was divided in three groups (normal, type I deficient and type III deficient) based on the levels of total and free protein S. In line with independent reports, ${ }^{16,17}$ type III protein S-deficient individuals were older than their normal and type I deficient relatives. Moreover, they had higher protein S (total, free and bound), 
prothrombin and TFPI levels than type I deficient individuals (Figure 2). Interestingly, a recent study reported that type III deficient individuals have elevated protein C levels as well. ${ }^{17}$ Since the levels of all these factors increase with age, ${ }^{36}$ our data support the hypothesis that type III deficient individuals from families with mixed type I/III deficiency start out as type I deficient, but become type III deficient later in life because of the age-related increase in total protein $\mathrm{S}$ levels. ${ }^{16}$ If this is the case, not only protein $\mathrm{S}$, protein $\mathrm{C}$ and prothrombin, but also other agedependent coagulation factors might be increased in type III deficient plasma. Differently, type I (but not type III) deficient individuals had markedly reduced full-length TFPI levels, in line with the recent observation that the levels of protein S and TFPI are highly correlated in plasma. ${ }^{38}$ These additional abnormalities in plasma factor levels may synergize with the low protein S levels to aggravate the hypercoagulable state associated with type I and type III protein $\mathrm{S}$ deficiencies and underscore the importance of global phenotyping tests to evaluate the associated thrombosis risk.

Despite the expectation (based on protein S and TFPI levels) that type I deficient plasma would be more procoagulant than type III deficient plasma, thrombin generation assays sensitive to the APC- and TFPI-cofactor activities of protein S detected only a minor difference between type I and type III deficient plasmas (Figures 4.3C and 4.4D,E). Remarkably, the slightly lower nAPCsr of type III deficient individuals as compared to type I deficient individuals was not due to a lower ETP ${ }_{+A P C}$, but to a higher ETP-APC (Figures 4.3A,B). Similarly, their higher PS- and TFPI-ratio was not due to a lower peak-Ab, but to a higher peak $_{+\alpha \mathrm{PS}}$ or peak $\mathrm{+}_{+\mathrm{TTFP}}$, respectively (Figures $4.4 \mathrm{~A}-\mathrm{C}$ ). Multiple regression analysis pointed at age and prothrombin, in addition to free protein $S$, as the major determinants of elevated thrombin generation in type III deficient plasma. While high prothrombin levels are known to cause APC-resistance, ${ }^{32}$ and to interfere with plasma assays that probe the APC-independent (TFPI-dependent) anticoagulant activity of protein $\mathrm{S}^{39}$ age might act by elevating the levels of several coagulation factors. ${ }^{36}$

Since both the nAPCsr and the TFPI-ratio reflect protein S (as well as TFPI) levels, they were highly correlated in the population (Figure 4.5). Only one type III individual showed a clear-cut discrepancy between nAPCsr and TFPI-ratio (Figure 4.5, arrow). This 69-year-old female had normal TFPI levels and the reason for her remarkable TFPI-sensitivity is presently unknown.

As the nAPCsr is a marker for thrombosis risk, ${ }^{40}$ the data presented in Figure $4.3 \mathrm{C}$ support the outcome of the Kaplan-Meier analysis and confirm that type I and type III protein $S$ deficiencies confer similar thrombosis risks. This finding is in line with a previous study, ${ }^{23}$ but 
contrasts with other studies where the risk of thrombosis associated with type III protein $\mathrm{S}$ deficiency was found to be lower than in type I deficiency ${ }^{24}$ or not elevated at all. ${ }^{22}$ A possible explanation for these discrepancies may be the population selection criteria, as it has been recently reported that type III deficient individuals from pure type III families are not at risk for thrombosis, while those from mixed type I/type III families are. ${ }^{24}$ Accordingly, all but two type III deficient individuals in our study belonged to families with mixed type I/III deficiency, and protein S Heerlen had a very low prevalence in our cohort. Moreover, the hypercoagulable state associated with type I deficiency might have been under-estimated in our functional studies, due to the exclusion of the most severe patients, who were on (lifelong) oral anticoagulants and therefore unsuitable for plasma phenotyping. These patients were however included in the Kaplan-Meier analysis.

In summary, we have shown that type I and type III protein S-deficient members of mixed type I/III families experience similar risks of venous thrombosis. This conclusion is based not only on Kaplan-Meier analyses, but also on a detailed characterization of the hypercoagulable states associated with type I and type III deficiencies, including the levels of several plasma factors, the APC-cofactor activity of protein $S$ and, for the first time, the TFPIcofactor activity of protein S. Although type I deficient individuals had lower protein S and TFPI levels than type III deficient individuals, the latter had higher levels of prothrombin and possibly other coagulation factors, resulting in an almost equivalent impairment of both anticoagulant functions of protein $\mathrm{S}$. These findings may have implications for the counseling and management of type III protein S-deficient patients. In particular, the correct assessment of the thrombosis risk in type III deficient individuals may require a detailed family study to distinguish mixed type I/III deficiency from pure type III deficiency due to PROS1 Heerlen or other (acquired?) causes. 


\section{REFERENCES}

1. Rezende SM, Simmonds RE, Lane DA. Coagulation, inflammation, and apoptosis: different roles for protein S and the protein S-C4b binding protein complex. Blood. 2004;103:1192-1201.

2. Dahlbäck B. The tale of protein $\mathrm{S}$ and $\mathrm{C} 4 \mathrm{~b}$-binding protein, a story of affection. Thromb Haemost. 2007;98:90-96.

3. Griffin JH, Gruber A, Fernández JA. Reevaluation of total, free, and bound protein $\mathrm{S}$ and C4bbinding protein levels in plasma anticoagulated with citrate or hirudin. Blood. 1992;79:3203-3211.

4. Castoldi E, Hackeng TM. Regulation of coagulation by protein S. Curr Opin Hematol. 2008;15:529536.

5. Walker FJ. Protein S and the regulation of activated protein C. Semin Thromb Hemost. 1984;10:131-138.

6. Hackeng TM, Seré KM, Tans G, Rosing J. Protein S stimulates inhibition of the tissue factor pathway by tissue factor pathway inhibitor. Proc Natl Acad Sci U S A. 2006;103:3106-3111.

7. Ndonwi M, Broze G, Jr. Protein S enhances the TFPI inhibition of factor Xa but not its inhibition of factor VIla/tissue factor. J Thromb Haemost. 2008;6:1044-1046.

8. Maurissen LF, Thomassen MC, Nicolaes GA, Dahlbäck B, Tans G, Rosing J, Hackeng TM. Reevaluation of the role of the protein $\mathrm{S}-\mathrm{C} 4 \mathrm{~b}$ binding protein complex in activated protein $\mathrm{C}$ catalyzed factor Va-inactivation. Blood. 2008;111:3034-3041.

9. Brugge JM, Tans G, Rosing J, Castoldi E. Protein S levels modulate the activated protein C resistance phenotype induced by elevated prothrombin levels. Thromb Haemost. 2006;95:236242.

10. Comp PC, Esmon CT. Recurrent venous thromboembolism in patients with a partial deficiency of protein S. N Engl J Med. 1984;311:1525-1528.

11. Schwarz HP, Fischer M, Hopmeier P, Batard MA, Griffin JH. Plasma protein S deficiency in familial thrombotic disease. Blood. 1984;64:1297-1300.

12. García de Frutos P, Fuentes-Prior P, Hurtado B, Sala N. Molecular basis of protein S deficiency. Thromb Haemost. 2007;98:543-556.

13. Liberti G, Bertina RM, Rosendaal FR. Hormonal state rather than age influences cut-off values of protein S: reevaluation of the thrombotic risk associated with protein $\mathrm{S}$ deficiency. Thromb Haemost. 1999;82:1093-1096.

14. ten Kate MK, van der Meer J. Protein S deficiency: a clinical perspective. Haemophilia. 2008; in press.

15. Zöller B, García de Frutos P, Dahlbäck B. Evaluation of the relationship between protein S and C4bbinding protein isoforms in hereditary protein S deficiency demonstrating type I and type III deficiencies to be phenotypic variants of the same genetic disease. Blood. 1995;85:3524-3531.

16. Simmonds RE, Zöller B, Ireland H, Thompson E, García de Frutos P, Dahlbäck B, Lane DA. Genetic and phenotypic analysis of a large (122-member) protein S-deficient kindred provides an explanation for the familial coexistence of type I and type III plasma phenotypes. Blood. 1997;89:4364-4370. 
17. ten Kate MK, Platteel M, Mulder R, Terpstra P, Nicolaes GA, Reitsma PH, van der Steege G, van der Meer J. PROS1 analysis in 87 pedigrees with hereditary protein $\mathrm{S}$ deficiency demonstrates striking genotype-phenotype associations. Hum Mutat. 2008;29:939-947.

18. Bertina RM, Ploos van Amstel HK, van Wijngaarden A, Coenen J, Leemhuis MP, Deutz-Terlouw PP, van der Linden IK, Reitsma PH. Heerlen polymorphism of protein S, an immunologic polymorphism due to dimorphism of residue 460. Blood. 1990;76:538-548.

19. Faioni EM, Valsecchi C, Palla A, Taioli E, Razzari C, Mannucci PM. Free protein S deficiency is a risk factor for venous thrombosis. Thromb Haemost. 1997;78:1343-1346.

20. Borgel D, Reny JL, Fischelis D, Gandrille S, Emmerich J, Fiessinger JN, Aiach M. Cleaved protein S (PS), total PS, free PS, and activated protein C cofactor activity as risk factors for venous thromboembolism. Clin Chem. 2003;49:575-580.

21. Biguzzi E, Razzari C, Lane DA, Castaman G, Cappellari A, Bucciarelli P, Fontana G, Margaglione M, D'Andrea G, Simmonds RE, Rezende SM, Preston R, Prisco D, Faioni EM. Molecular diversity and thrombotic risk in protein S deficiency: the PROSIT study. Hum Mutat. 2005;25:259-269.

22. Libourel EJ, Bank I, Veeger NJ, Hamulyák K, Middeldorp S, Prins MH, Büller HR, van der Meer J. Protein S type III deficiency is no risk factor for venous and arterial thromboembolism in 168 thrombophilic families: a retrospective study. Blood Coagul Fibrinolysis. 2005;16:135-140.

23. Mateo J, Oliver A, Borrell M, Sala N, Fontcuberta J. Increased risk of venous thrombosis in carriers of natural anticoagulant deficiencies. Results of the family studies of the Spanish Multicenter Study on Thrombophilia (EMET study). Blood Coagul Fibrinolysis. 1998;9:71-78.

24. Brouwer JL, Veeger NJ, van der Schaaf W, Kluin-Nelemans HC, van der Meer J. Difference in absolute risk of venous and arterial thrombosis between familial protein S deficiency type I and type III. Results from a family cohort study to assess the clinical impact of a laboratory test-based classification. Br J Haematol. 2005;128:703-710.

25. Sanson BJ, Simioni $P$, Tormene D, Moia M, Friederich PW, Huisman MV, Prandoni P, Bura A, Rejto L, Wells P, Mannucci PM, Girolami A, Büller HR, Prins MH. The incidence of venous thromboembolism in asymptomatic carriers of a deficiency of antithrombin, protein $\mathrm{C}$, or protein S: a prospective cohort study. Blood. 1999;94:3702-3706.

26. Simioni P, Sanson BJ, Prandoni P, Tormene D, Friederich PW, Girolami B, Gavasso S, Huisman MV, Büller HR, ten Cate JW, Girolami A, Prins MH. Incidence of venous thromboembolism in families with inherited thrombophilia. Thromb Haemost. 1999;81:198-202.

27. Simmonds RE, Ireland H, Lane DA, Zöller B, García de Frutos P, Dahlbäck B. Clarification of the risk for venous thrombosis associated with hereditary protein $\mathrm{S}$ deficiency by investigation of a large kindred with a characterized gene defect. Ann Intern Med. 1998;128:8-14.

28. Makris M, Leach M, Beauchamp NJ, Daly ME, Cooper PC, Hampton KK, Bayliss P, Peake IR, Miller GJ, Preston FE. Genetic analysis, phenotypic diagnosis, and risk of venous thrombosis in families with inherited deficiencies of protein S. Blood. 2000;95:1935-1941.

29. de Wolf CJ, Cupers RM, Bertina RM, Vos HL. The constitutive expression of anticoagulant protein S is regulated through multiple binding sites for Sp1 and Sp3 transcription factors in the protein $\mathrm{S}$ gene promoter. J Biol Chem. 2006;281:17635-17643.

30. Mustafa S, Pabinger I, Mannhalter C. Two new frequent dimorphisms in the protein S (PROS1) gene. Thromb Haemost. 1996;76:393-396. 
31. Diepstraten CM, van Amstel JK, Reitsma PH, Bertina RM. A CCA/CCG neutral dimorphism in the codon for Pro 626 of the human protein S gene PS alpha (PROS1). Nucleic Acids Res. 1991;19:5091.

32. Castoldi E, Simioni P, Tormene D, Thomassen MC, Spiezia L, Gavasso S, Rosing J. Differential effects of high prothrombin levels on thrombin generation depending on the cause of the hyperprothrombinemia. J Thromb Haemost. 2007;5:971-979.

33. Seré KM, Janssen MP, Willems GM, Tans G, Rosing J, Hackeng TM. Purified protein S contains multimeric forms with increased APC-independent anticoagulant activity. Biochemistry. 2001;40:8852-8860.

34. Koenen RR, Christella M, Thomassen LG, Tans G, Rosing J, Hackeng TM. Effect of oral contraceptives on the anticoagulant activity of protein $\mathrm{S}$ in plasma. Thromb Haemost. 2005;93:853-859.

35. Hemker HC, Giesen P, AlDieri R, Regnault V, de Smed E, Wagenvoord R, Lecompte T, Béguin S. The calibrated automated thrombogram (CAT): a universal routine test for hyper- and hypocoagulability. Pathophysiol Haemost Thromb. 2002;32:249-253.

36. Dielis AW, Castoldi E, Spronk HM, van Oerle R, Hamulyák K, Ten Cate H, Rosing J. Coagulation factors and the protein $\mathrm{C}$ system as determinants of thrombin generation in a normal population. J Thromb Haemost. 2008;6:125-131.

37. Giri TK, García de Frutos P, Dahlbäck B. Protein S Thr103Asn mutation associated with type II deficiency reproduced in vitro and functionally characterised. Thromb Haemost. 2000;84:413-419.

38. Dahm AE, Sandset PM, Rosendaal FR. The association between protein S levels and anticoagulant activity of tissue factor pathway inhibitor type 1. J Thromb Haemost. 2008;6:393-395.

39. Koenen RR, Tans G, van Oerle R, Hamulyák K, Rosing J, Hackeng TM. The APC-independent anticoagulant activity of protein $\mathrm{S}$ in plasma is decreased by elevated prothrombin levels due to the prothrombin G20210A mutation. Blood. 2003;102:1686-1692.

40. Tans G, van Hylckama Vlieg A, Thomassen MC, Curvers J, Bertina RM, Rosing J, Rosendaal FR. Activated protein $\mathrm{C}$ resistance determined with a thrombin generation-based test predicts for venous thrombosis in men and women. Br J Haematol. 2003;122:465-470.

41. Gandrille S, Borgel D, Eschwege-Gufflet V, Aillaud M, Dreyfus M, Matheron C, Gaussem P, Abgrall $J F$, Jude B, Sie P, Toulon P, Aiach M. Identification of 15 different candidate causal point mutations and three polymorphisms in 19 patients with protein $\mathrm{S}$ deficiency using a scanning method for the analysis of the protein S active gene. Blood. 1995;85:130-138.

42. Simmonds RE, Ireland H, Kunz G, Lane DA. Identification of 19 protein $S$ gene mutations in patients with phenotypic protein S deficiency and thrombosis. Protein S Study Group. Blood. 1996;88:41954204.

43. Marchetti G, Legnani C, Patracchini P, Gemmati D, Ferrati M, Palareti G, Coccheri S, Bernardi F. Study of a protein $\mathrm{S}$ gene polymorphism at DNA and mRNA level in a family with symptomatic protein S deficiency. Br J Haematol. 1993;85:173-175.

44. Formstone CJ, Wacey Al, Berg LP, Rahman S, Bevan D, Rowley M, Voke J, Bernardi F, Legnani C, Simioni P, Girolami A, Tuddenham EG, Kakkar VV, Cooper DN. Detection and characterization of seven novel protein $S$ (PROS) gene lesions: evaluation of reverse transcript-polymerase chain reaction as a mutation screening strategy. Blood. 1995;86:2632-2641. 
45. Rezende SM, Lane DA, Zöller B, Mille-Baker B, Laffan M, Dalhbäck B, Simmonds RE. Genetic and phenotypic variability between families with hereditary protein $\mathrm{S}$ deficiency. Thromb Haemost. 2002;87:258-265.

46. Beauchamp NJ, Dykes AC, Parikh N, Campbell Tait R, Daly ME. The prevalence of, and molecular defects underlying, inherited protein $\mathrm{S}$ deficiency in the general population. $\mathrm{Br} \mathrm{J}$ Haematol. 2004;125:647-654.

47. Espinosa-Parrilla Y, Morell M, Souto JC, Tirado I, Fontcuberta J, Estivill X, Sala N. Protein S gene analysis reveals the presence of a cosegregating mutation in most pedigrees with type I but not type III PS deficiency. Hum Mutat. 1999;14:30-39.

48. Beauchamp NJ, Daly ME, Cooper PC, Makris M, Preston FE, Peake IR. Molecular basis of protein S deficiency in three families also showing independent inheritance of factor $V$ leiden. Blood. 1996;88:1700-1707.

49. Hermida J, Faioni EM, Mannucci PM. Poor relationship between phenotypes of protein S deficiency and mutations in the protein S alpha gene. Thromb Haemost. 1999;82:1634-1638.

50. Schmidel DK, Tatro AV, Phelps LG, Tomczak JA, Long GL. Organization of the human protein S genes. Biochemistry. 1990;29:7845-7852. 




\section{Chapter 5}

Effect of oral contraceptives on the down-regulation of thrombin generation by the TFPI and protein C pathways

Lisbeth F.A. Maurissen, Jan Rosing, Tilman M. Hackeng 



\section{SUMMARY}

Protein $S$ is the non-enzymatic cofactor of both activated protein C (APC) and tissue factor pathway inhibitor (TFPI). In the current study, we investigated the effect of oral contraceptive (OC) use on the down-regulation of thrombin generation by the TFPI- and protein C pathways. Full length TFPI and total and free protein S levels were measured in 6 men, 12 women not using OC, 17 women using second- and 19 women using third generation $\mathrm{OC}$, and the relation between TPFI and protein S levels and the TFPI- and APC-cofactor activities of protein S was determined. Compared with men and non-OC using women, women using second generation oral contraceptives had significantly lower TFPI-cofactor activities of protein $S$ (pSR) and higher APC-resistance ratios (APCsr). Both the $\mathrm{PSR}$ and the APCsr were associated with a decrease in full length TFPI. Second generation pill users had lower TFPI levels than non-OC using women. This explains why second generation OC users, despite similar protein S levels, had a lower PSR than women who did not use OC. Women using third generation oral contraceptives had even a lower pSR and a higher APCsr than second generation pill users. The differences in PSR and APCsr between second and third generation OC users were mainly due to a further decreases in full length TFPI and protein $\mathrm{S}$ levels in the third generation OC users. We propose that the anticoagulant TFPI/protein S pathway in second generation OC users is impaired due to a decrease in full length TFPI levels. The decrease in full length TFPI levels contributes to the increased APC-resistance in OC users. 


\section{INTRODUCTION}

Protein $\mathrm{S}$ is an anticoagulant vitamin K-dependent protein that participates in the down-regulation of blood coagulation by multiple mechanisms. Protein $\mathrm{S}$ acts as a nonenzymatic cofactor for activated protein C (APC) which accelerates the APC-mediated inactivation of factor Va and factor VIIIa ${ }^{1-3}$. Inactivation of factor Va by APC occurs by limited proteolysis at residues $\mathrm{R}^{306}, \mathrm{R}^{506}, \mathrm{R}^{679} 4$. Optimal inactivation of factor $\mathrm{Va}$ by APC requires the presence of negatively charged phospholipids and its cofactor protein $S^{5-7}$. Protein $S$ stimulates APC-catalyzed proteolysis at $\mathrm{R}^{306}$ of factor Va approximately 20 -fold ${ }^{7,8}$.

Protein S also expresses APC-independent anticoagulant activity. Recently, it was reported that protein $\mathrm{S}$ acts as a cofactor activity of tissue factor pathway inhibitor (TFPI) in down-regulating tissue factor (TF) activity ${ }^{9}$. TFPI is a Kunitz-type serine protease inhibitor that inhibits TF-induced blood coagulation by a two step mechanism ${ }^{10}$. TFPI first forms a bimolecular complex with factor Xa that subsequently inhibits the TF/factor VIla complex by forming a quaternary complex ${ }^{11,12}$. Kinetic analysis showed that protein $S$ enhances the formation of the factor Xa/TFPI complex $\sim 10$-fold ${ }^{9}$.

Oral contraceptives $(\mathrm{OC})$ use results in decreased protein $\mathrm{S}$ levels in plasma and in increased APC-resistance, a hypercoagulable state that is characterized by an impaired response of plasma to the anticoagulant action of APC ${ }^{13,14}$. It has been reported that APCresistance measured with a thrombin generation-based assay is increased with decreased levels of free protein $\mathrm{S}^{15}$ and is associated with an increased risk for venous thrombosis ${ }^{16}$.

The TFPI level and activity are also decreased by OC-use ${ }^{17}$. TFPI was reported to be a determinant of the thrombin generation-based APC resistance test ${ }^{15}$ and like protein $\mathrm{S}$ deficiency ${ }^{18}$, TFPI deficiency is associated with an increased risk for venous thrombosis ${ }^{19}$.

OC use is also associated with an impaired APC-independent activity of protein $\mathrm{S}^{20}$. A significant decrease in the APC-independent activity of protein $S(p S R)$ was observed in women using second generation OC compared to non-OC using women, although they had similar levels of free and total protein S. To explain this observation, a possible modulation of protein $\mathrm{S}$ activity by an unidentified plasma protein was suggested ${ }^{20}$.

Since it was recently shown that protein $S$ acts as a cofactor of TFPI in the down regulating of tissue factor-induced thrombin generation, we have investigated the role of TFPI in the changes of the APC-dependent and APC-independent anticoagulant activities of protein S associated with OC-use. 


\section{METHODS}

\section{Materials}

Hepes was purchased from Sigma, bovine serum albumin from ICN. Fluorogenic substrate I-1140 was from Bachem, Switzerland. 1,2-Dioleoyl-sn-glycero-3-phosphocholine (DOPC), 1,2-Dioleoyl-sn-glycero-3-phosphoserine (DOPS) and 1,2-Dioleoyl-sn-glycero-3phosphoethanolamine (DOPE) were obtained from Avanti Polar Lipids (Alabaster, Alabama, USA). Phospholipids vesicles (20\% DOPS, 20\% DOPE, 60\% DOPC) were prepared as described previously ${ }^{21}$. Monoclonal antibodies against TFPI (MW1845 and MW1848) were purchased from Sanquin (Amsterdam, the Netherlands). Peroxidase Kit. 3, 5, 3', 5'-tetramethylbenzidine (TMB) was obtained from Pierce (Rockford, USA). Tissue factor (TF) was from Dade Innovin (Behring, Germany) and CTI was obtained from Haematologic Technologies Inc. (Vermont, USA). Human APC was obtained from Kordia life sciences (Leiden, the Netherlands). Free TFPI ELISA kits were obtained from Stago (Asserachrom Free TFPI, Diagnostica Stago, Asnieres, France).

\section{Plasma samples}

Plasma samples were obtained as previously described ${ }^{20} .54$ samples were available for analysis, men ( $n=6$, mean age 25.5), women not using $O C(n=13$, mean age 26.5$)$, women using second generation OC containing ethinylestradiol and levonorgestrol $(n=17$, mean age 24.5) and women using third generation OC containing ethinylestradiol and desogestrel or gestodene ( $n=18$, mean age 24.8). Women not using $O C$ were neither pregnant nor menopausal.

Determination of protein $S$ concentrations and APC-independent anticoagulant activity of protein S in plasma.

Levels of total and free protein S and the nAPC-sr were measured as described earlier 20.

Anticoagulant activity of protein $S$ measured by thrombin generation based assay.

As a measure for the APC-cofactor activity of protein $\mathrm{S}$, thrombin generation was initiated with $6.8 \mathrm{pM} \mathrm{TF}, 30 \mu \mathrm{M}$ phospholipids and $16 \mathrm{mM} \mathrm{CaCl}_{2}$ (final concentration) in the absence and presence of $3 \mathrm{nM}$ human APC and followed with fluorogenic substrate I-1140. This assay was performed in plasma of men, women not using OC, women using second 
generation $O C$ and women using third generation $O C$. The outcome of the assay was expressed as the APC sensitivity ratio (APCsr) which was defined the ratio of the endogenous thrombin potentials (ETP) determined in the presence and absence of APC normalized by division through the same ratio measured in normal pooled plasma.

To determine the TFPI-cofactor activity of protein $\mathrm{S}$ and the overall anticoagulant activity of the TFPI/protein S system, thrombin generation was initiated with $1.36 \mathrm{pM} \mathrm{TF}, 30$ $\mu \mathrm{M}$ phospholipids and $16 \mathrm{mM} \mathrm{CaCl} 2$ and followed with the fluorogenic substrate I-1140. Prior to initiation of thrombin generation $68 \mu \mathrm{l}$ plasma was incubated during 15 minutes at $37^{\circ} \mathrm{C}$ with $8 \mu$ l antibodies against protein $\mathrm{S}(2.80 \mu \mathrm{M})$ or TFPI $(0.66 \mu \mathrm{M})$ or HN buffer. To prevent contact activation $33 \mu \mathrm{g} / \mathrm{ml}$ CTI was added.

To investigate the effects of protein S and TFPI on the expression of anticoagulant activity of APC, thrombin generation was measured in plasma that was deficient in both protein S and TFPI and that was or was not reconstituted with TFPI and/or protein S. In short, thrombin generation was initiated in protein S-depleted plasma with $13.6 \mathrm{pM}$ TF and $20 \mu \mathrm{M}$ of phospholipids vesicles (20/60/20 DOPS/DOPC/DOPE) and $16 \mathrm{mM} \mathrm{CaCl}_{2}$ and followed with fluorogenic substrate I-1140. Prior to initiation of thrombin generation, protein S-depleted plasma was reconstituted with $0.3 \mathrm{nM}$ full-length TFPI or neutralized with antibodies against full-length TFPI (depleted) and with or without $350 \mathrm{nM}$ protein S. TFPI (0.3 nM) was added to protein S-depleted plasma since this contained low full-length TFPI levels. Different amounts (0-35 nM) of APC were added to plasma. The concentrations given in the description of the various thrombin generation assays are final concentrations in plasma.

In order to correct for inner-filter effects and substrate consumption, each thrombin generation measurement was calibrated against fluorescence curve obtained in the same plasma with a fixed amount of thrombin $\alpha 2$-macroglobulin complex. The fluorescence change was read in a Fluoroskan Ascent reader equipped with a 390/460 filter set and thrombin generation curves were calculated using the Thrombinoscope software ${ }^{22}$.

\section{Full length TFPI ELISA}

Microtiter plate wells were coated overnight at $4^{\circ} \mathrm{C}$ with $50 \mu \mathrm{l}$ of a solution containing $2 \mu \mathrm{g} / \mathrm{ml}$ of a monoclonal antibody against C-terminal region of TFPI in $0.1 \mathrm{M} \mathrm{Na}_{2} \mathrm{CO}_{3}, \mathrm{pH}$ 9.0. Further steps were performed at room temperature. After coating, the wells were blocked with $200 \mu$ l of blocking buffer consisting of Hepes-buffered saline (HBS: 25 mM Hepes, pH 7.9, $175 \mathrm{mM} \mathrm{NaCl}$ ) containing $30 \mathrm{mg} / \mathrm{ml}$ BSA for 2 hours. Plasma samples were diluted 1:5 in blocking buffer and $50 \mu \mathrm{l}$ of the diluted plasma was incubated in the wells for 1 hour. After 
washing 3 times with $200 \mu$ l washing buffer (HBS containing $0.03 \%$ Tween-20), $50 \mu$ of a peroxidase-conjugated monoclonal anti-human TFPI antibody against Kunitz-2 domain diluted $1 / 1000(2 \mu \mathrm{g} / \mathrm{ml})$ in HBS containing $5 \mathrm{mg} / \mathrm{ml} \mathrm{BSA}$ was added to the wells and incubated for 1 hour. After 5 times washing with $200 \mu$ l washing buffer, peroxidase activity was determined by chromogenic substrate conversion (TMB enzymatic kit) according to manufacturer's instructions. Normal pooled plasma dilutions were used as standards. Peroxidase conjugation of monoclonal anti-human TFPI was performed according to manufacturer's instructions. 


\section{RESULTS}

\section{Effect of OC on protein S and TFPI levels in plasma}

Total and free protein $\mathrm{S}$ levels were higher in men than in women. Women not using $O C$ and second generation $O C$ users had similar plasma levels protein $\mathrm{S}$ which were significantly higher, however, than the protein $\mathrm{S}$ levels in women using third generation $\mathrm{OC}$ (Table 5.1).

Since full length TFPI is the form of TFPI that is most effective in down-regulating the TF pathway ${ }^{23,24}$, an ELISA was developed to determine the levels of full length TFPI in plasma (Chapter 3). Full length TFPI was quantified using a capturing monoclonal antibody against the C-terminus of TFPI, and a peroxidase-conjugated monoclonal antibody against the Kunitz-2 domain of TFPI as detection antibody.

This assay showed clear differences between full length TFPI levels in plasma of men, women and OC users (Table 5.1, Fig 5.1A). Men had full length TFPI levels of $109 \mathrm{U} / \mathrm{dl}$, while non-OC using women had lower levels of $80 \pm 16 \mathrm{U} / \mathrm{dl}$ full length TFPI. Significant differences were observed between women not using $O C$ and women using second (62 $\pm 27 \mathrm{U} / \mathrm{dl})$ or third generation OC (34 $\pm 19 \mathrm{U} / \mathrm{dl})$.
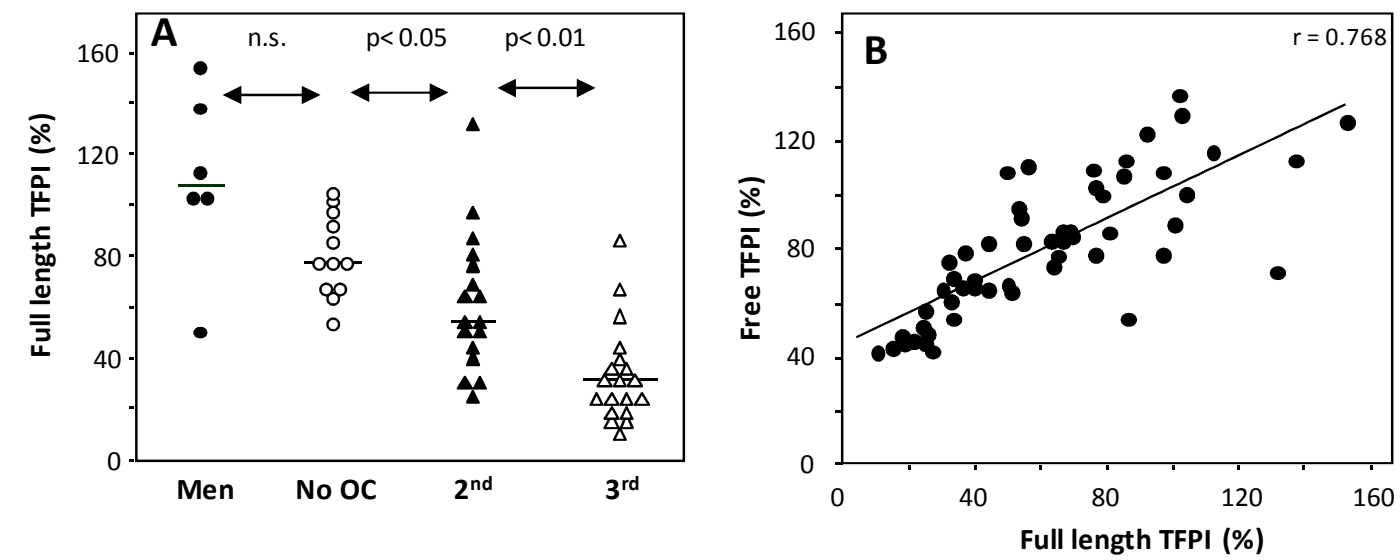

Figure 5.1: Effect of oral contraceptives on levels of full length TFPI levels in plasma. A: Levels of full length TFPI were measured with full length TFPI ELISA in men (O), women not using OC $(O)$, women using second generation $\mathrm{OC}(\mathbf{\Delta})$ and women using third generation $\mathrm{OC}(\triangle)$. B: Scatter diagram and linear regression line of full length TFPI levels (independent variable) and free TFPI levels (dependent variable) in men, women, and women using second- or third-generation OC.

It was earlier reported that free TFPI is the active anticoagulant form of TFPI in plasma ${ }^{25}$. Free TFPI levels, measured with a commercially available ELISA, showed differences in the 
various sub-populations that were similar to those observed for full-length TFPI (Table 5.1), and a significant correlation was observed between full length TFPI and free TFPI (Fig. 1B).

Table 5.1: Effects of OC use on plasma protein S and TFPI levels.

\begin{tabular}{|l|c|c|c|c|}
\hline \multicolumn{1}{|c|}{ Population } & $\begin{array}{c}\text { Total protein S } \\
\text { (U/dl } \pm \text { S.D.) }\end{array}$ & $\begin{array}{c}\text { Free protein S } \\
\text { (U/dl } \pm \text { S.D.) }\end{array}$ & $\begin{array}{c}\text { Full length TFPI } \\
\text { (U/dl } \pm \text { S.D.) }\end{array}$ & $\begin{array}{c}\text { Free TFPI } \\
\text { (U/dl } \pm \text { S.D.) }\end{array}$ \\
\hline men (n=6) & $96 \pm 8$ & $106 \pm 11$ & $109 \pm 36$ & $122 \pm 11$ \\
\hline $\begin{array}{l}\text { Women no OC } \\
(\mathbf{n}=13)\end{array}$ & $85 \pm 11^{\mathrm{a}}$ & $89 \pm 19^{\mathrm{a}}$ & $80 \pm 16^{\mathrm{a}}$ & $98 \pm 13^{\mathrm{b}}$ \\
\hline $\begin{array}{l}\text { second generation } \\
\text { OC (n=17) }\end{array}$ & $85 \pm 10$ & $94 \pm 15$ & $62 \pm 27$ & $74 \pm 14$ \\
\hline $\begin{array}{l}\text { third generation OC } \\
(\mathbf{n}=\mathbf{1 8})\end{array}$ & $78 \pm 10^{\mathrm{c}}$ & $76 \pm 16^{\mathrm{c}}$ & $34 \pm 19^{\mathrm{c}}$ & $61 \pm 19^{\mathrm{d}}$ \\
\hline
\end{tabular}

${ }^{a}: p<0.05$ compared to men; ${ }^{b}: p<0.01$ compared to men, second generation, ${ }^{c}: p<0.05$ compared to second generation $O C_{;}{ }^{d}: p<0.01$ compared to second generation $O C$.

The effect of OC use on the cofactor activities of protein S.

Functional activities of protein S and TFPI were determined in pooled plasma of men, women not using $\mathrm{OC}$, and women using second-generation or third generation $\mathrm{OC}$ by measuring the effects of anti-protein $S$ and anti-TFPI antibodies on thrombin generation. Thrombin generation in plasma from men (Fig. 5.2A) and from women not using OC (Fig. 5.2B) was much lower than that in plasma from second (Fig. 5.2C) and third generation OC users (Fig. 5.2D). Addition of antibodies against protein S (closed circles) and of antibodies against TFPI (open triangles) increased thrombin generation due to inhibition of TFPI-cofactor activity of protein $\mathrm{S}$ and inhibition of the overall activity of the TFPI/protein S system, respectively. However, the addition of antibodies against protein S and TFPI had a much less effect on thrombin generation in plasma of women using $O C$ than on thrombin generation in plasma from men and non-OC using women. This is indicative for reduced protein $\mathrm{S}$ and full length TFPI activities in OC users and suggests that thrombin generation determined in the absence of antibodies (open circles) is lower in men and non-OC using women than in OC users because it is more effectively suppressed by protein S and TFPI. 

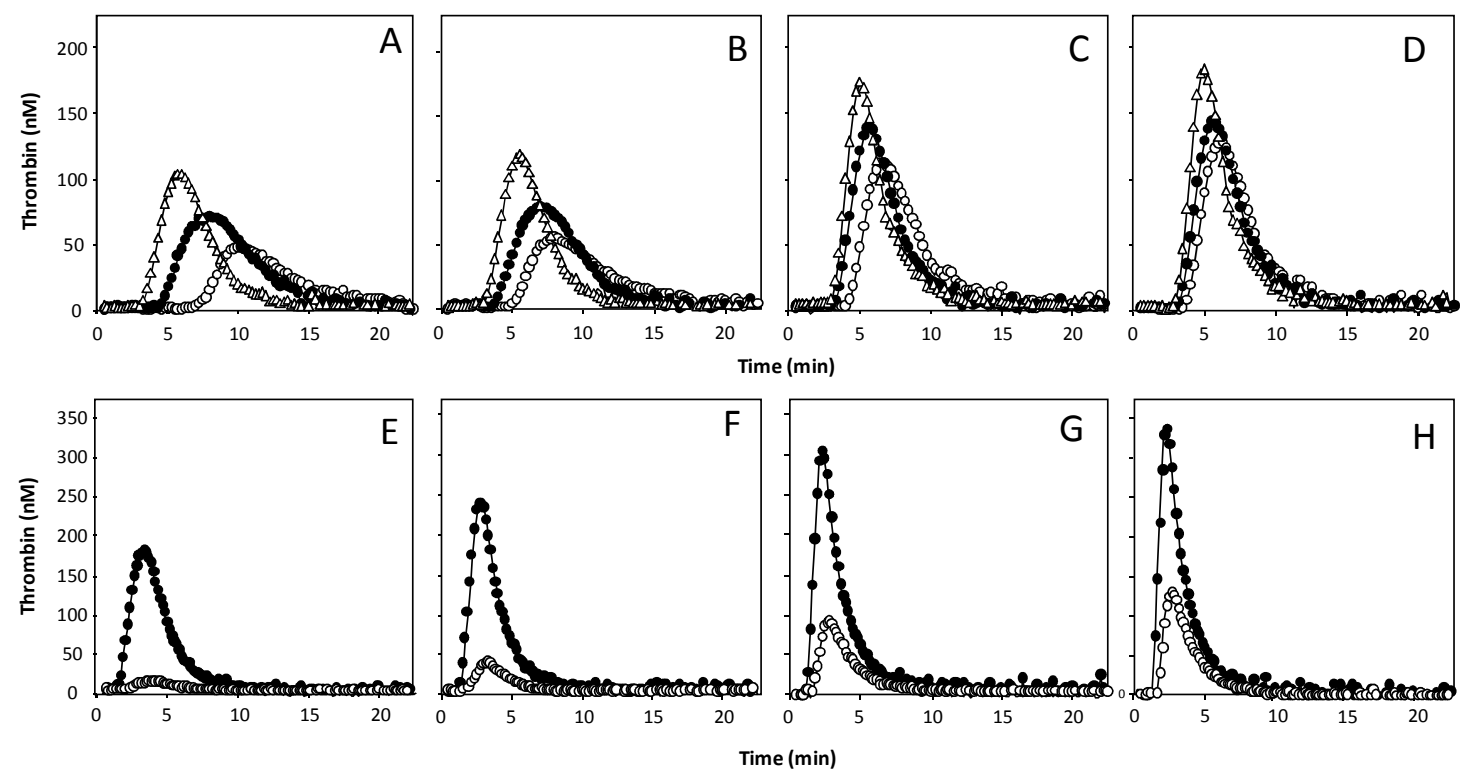

Figure 5.2: Effect of oral contraceptives on anticoagulant cofactor activity of protein $\mathbf{S}$ for TFPI and APC Thrombin generation was measured in pooled plasma of men $(A, E)$, non-OC using women $(B, F)$, women using second generation $(C, G)$ or third generation $O C(D, H)$ in the absence of antibodies $(O ; A-D))$ or in the presence of antibodies against protein $S(O ; A-D)$ or TFPI $(\triangle$; A-D). Thrombin generation was also measured in the same pooled plasmas in the absence $(\mathbf{O})$ and presence (O) of APC (E-H).

Information about the APC-cofactor activity of protein S was obtained by determining thrombin generation in the absence and presence of added APC. Under the test conditions, the anticoagulant activity of APC is almost completely dependent on the presence of protein S 29. However, TFPI, also appears to be an important determinant of thrombin generation determined in the presence of APC and of the nAPCsr ${ }^{28}$. Thrombin generation in the presence of APC (Fig. 5.2 E-H) as well as the APCsr (Table 5.2, Fig. 5.3A) gradually increased in the order men $<$ women not using $\mathrm{OC}<$ women using second generation $\mathrm{OC}<$ women using third generation OC. Since protein S and TFPI are major determinants of the nAPCsr ${ }^{15}$, it is likely that the gradual increase of thrombin generation and the nAPCsr in the subgroups is mainly due to the gradual decrease of protein S and/or TFPI (Table 5.1).

In a previous study, the APC-independent anticoagulant activity of protein S was expressed as the ratio of a clotting times (pSR) determined in plasma in the presence and absence of anti-protein $\mathrm{S}$ antibodies ${ }^{26}$. Due to inhibition of APC-independent activity of protein $\mathrm{S}$ by these antibodies, clotting times in the presence of antibodies were shortened. As the lag time of thrombin generation in plasma corresponds to the clotting time of plasma ${ }^{27}$, the PSR's in the present populations were determined by the ratio of lag times of thrombin generation curves in the presence and absence of antibodies against protein S (Fig. 5.3B). The 
pSR significantly decreased from men to non-using women, to women using oral contraceptives. There was no difference between women using second-generation $O C$ and women using third generation $\mathrm{OC}$.

Table 5.2: Effect of gender and OC use on $\mathrm{PSR}$ and APCsr

\begin{tabular}{|l|c|c|}
\hline Population & $\begin{array}{c}\text { PSR } \\
\text { ( } \pm \text { S.D.) }\end{array}$ & $\begin{array}{c}\text { APC-sr } \\
\text { ( } \pm \text { S.D.) }\end{array}$ \\
\hline Men (n=6) & $1.74 \pm 0.06$ & $1.03 \pm 0.57$ \\
\hline Women no OC ( $\mathbf{n}=\mathbf{1 3 )}$ & $1.48 \pm 0.07^{\mathrm{b}}$ & $1.76 \pm 0.54^{\mathrm{b}}$ \\
\hline second generation OC ( $\mathbf{n = 1 7 )}$ & $1.35 \pm 0.08$ & $2.98 \pm 0.58$ \\
\hline third generation OC $(\mathbf{n}=\mathbf{1 8})$ & $1.28 \pm 0.06^{\mathrm{d}}$ & $4.26 \pm 0.92^{\mathrm{d}}$ \\
\hline
\end{tabular}

${ }^{a}: p<0.05$ compared to men, second generation; ${ }^{b}: p<0.001$ compared to men, second generation; ${ }^{c}: p$ $<0.001$ compared to second generation; ${ }^{d}: p<0.05$ compared to second generation.

In chapter 3 of this thesis we described the development of functional tests for the TFPI/protein S pathway. In that chapter the TFPI cofactor activity of protein S and the overall activity of the TFPI/protein S system were expressed as the ratio of the peak heights of thrombin generation without and with anti-protein S (protein S ratio) and the ratio of peak heights of thrombin generation without and with anti-TFPI (TFPI ratio), respectively. The protein $\mathrm{S}$ ratio as well as the TFPI ratios determined via this procedure gradually increased in the order men $<$ women not using $\mathrm{OC}<$ women using second generation $\mathrm{OC}<$ women using third generation OC (Fig. 5.3C,D), which is indicative for a gradual reduction of the activity of the TFPI/protein S pathway. The differences between the various subgroups was, however, not always significant. This may be due to the small populations and/or the relatively small window of the protein S- and TFPI-ratios. 

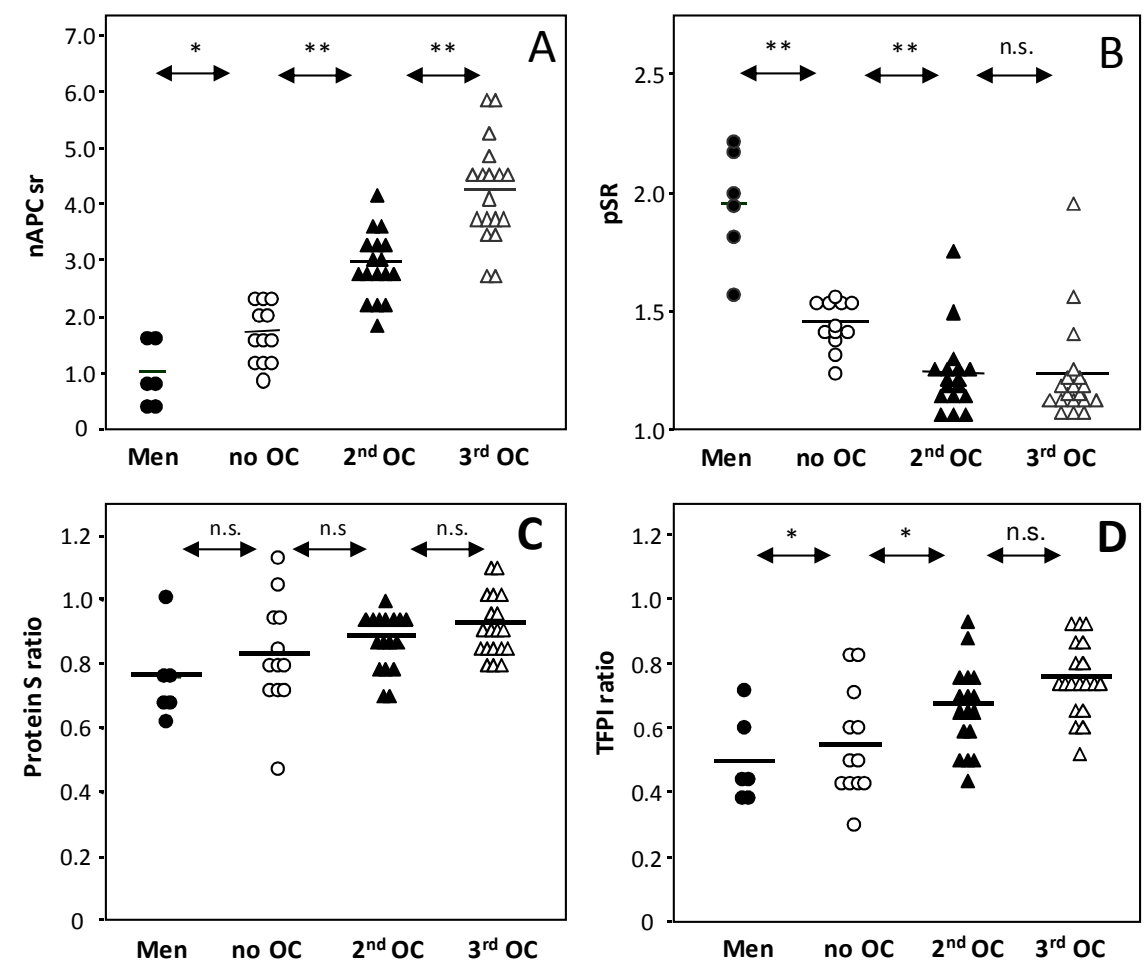

Figure 5.3: Effect of oral contraceptives on the APCsr and the pSR. The APCsr (A), the protein S ratio (pSR) calculated from lag times of thrombin generation curves $(B)$, and the protein $S$ ratio (C) and TFPI ratio (D) calculated from peak heights of thrombin generation curves were measured in men (O), women not using OC $(O)$, women using second generation OC $(\mathbf{\Delta})$ and women using third-generation OC $(\triangle)$.

Correlation between the different parameters that modulate the activities of the TFPI- and protein C pathways.

Fig. 5.4A-D shows that the pSR as well as the APCsr significantly correlates with both full length TFPI and protein S levels. In view of the reported TFPI-cofactor activity of protein S ${ }^{9}$, the correlation between the PSR and TFPI explains why women using second-generation OC have a lower PSR than non-OC using women although both have identical levels of free and total protein S. This difference is apparently due to lower TFPI levels in second generation OC users. The APC-independent activity of protein S (pSR) calculated from the lag times of the thrombin generation curves inversely correlated with the nAPC-sr of different groups (Fig. $5.5)$. 

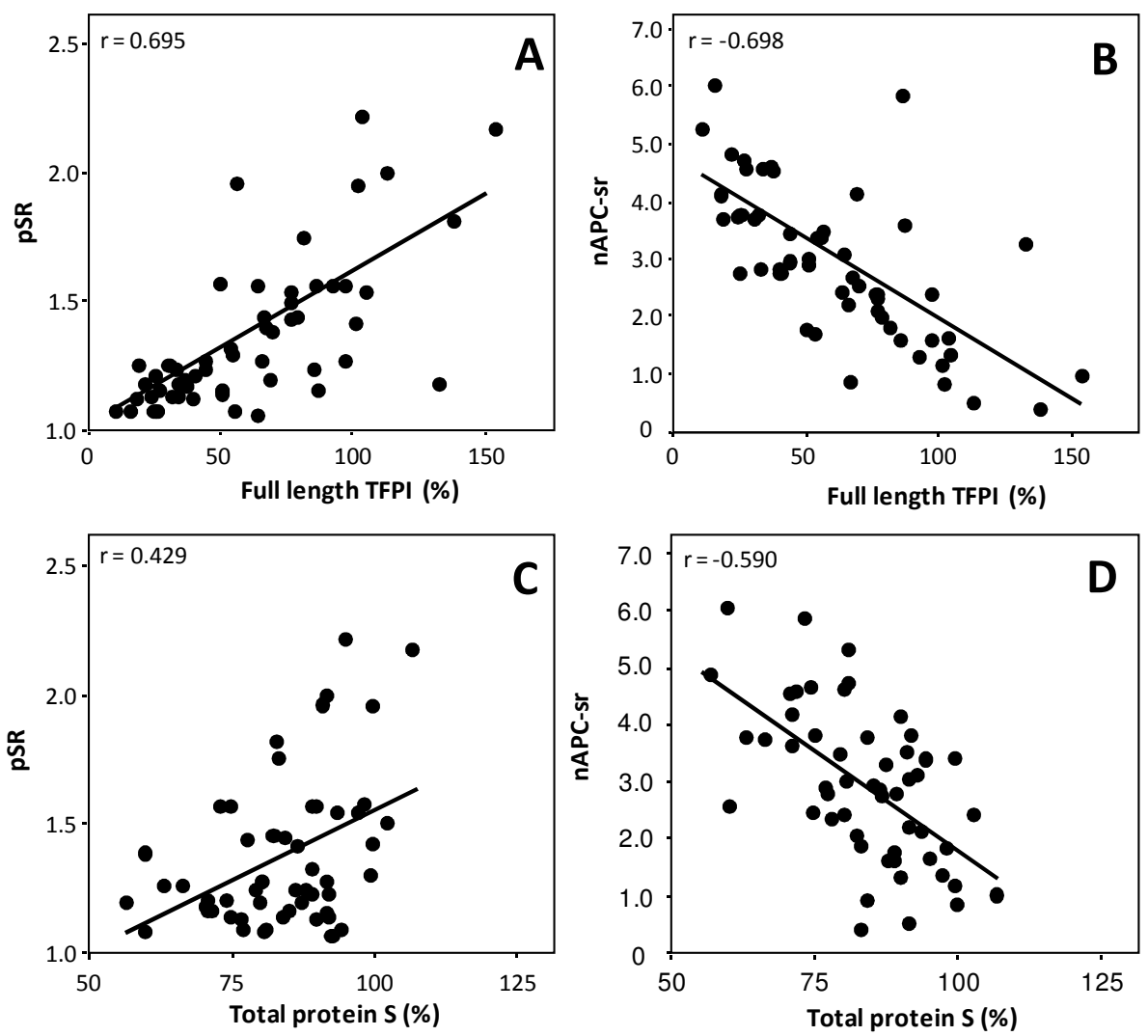

Figure 5.4: Correlations of full length TFPI levels in plasma with protein $S$ and APC activity Scatter diagrams and linear regression lines of (A) full length TFPI levels and the pSR, (B) full length TFPI levels and the nAPC-sr, (C) total protein S levels and the pSR, and (D) total protein S levels and the nAPC-sr in men, women, and women using second- or third-generation OC.

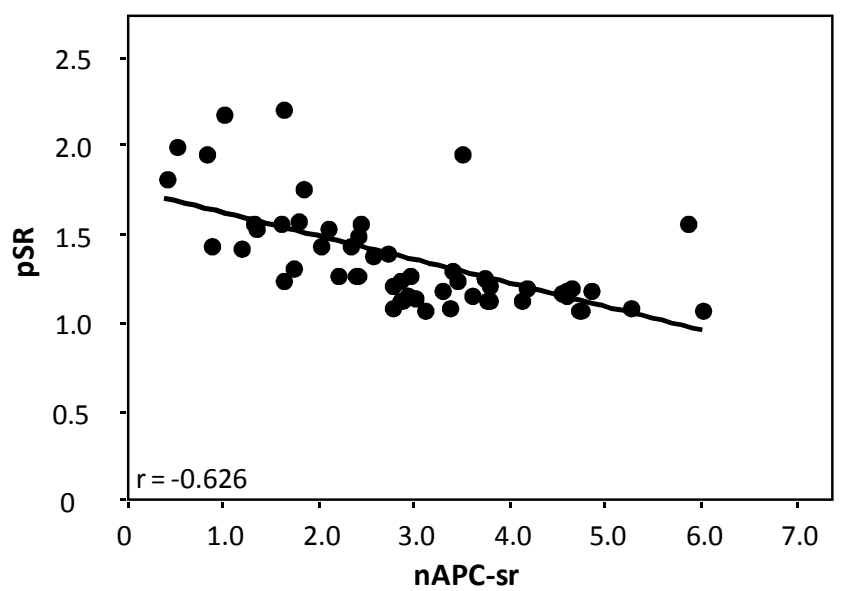

Figure 5.5: Correlation between the protein $S$ ratio (pSR) and the nAPCsr. Scatter diagram and linear regression line of the protein $S$ ratio (PSR) calculated from lag times of thrombin generation curves and the nAPCsr in men, women, and women using second- or third-generation OC. 
Effect of TFPI and protein S on the down-regulation of thrombin generation by APC.

The plasma levels of full length (free) TFPI and protein $\mathrm{S}$ are major determinants of the APC-resistance test ${ }^{15,28}$ (Fig. 5.4B, D). Notably, TFPI only inhibits thrombin generation when coagulation is triggered with low TF concentrations ${ }^{29}$. Since the APC-resistance test is performed at TF-concentrations that are too high to allow down-regulation by protein S/TFPI, it is difficult to understand how TFPI can be a major determinant of the APC-resistance test. A possible explanation might be that APC down-regulates the procoagulant response of high TF concentrations to a level similar to that induced by low TF-concentrations. In the presence of APC thrombin generation is slowed down and delayed and it is possible that under these conditions the TFPI/protein $S$ anticoagulant pathway superimposes its activity on the APC/protein S pathway.

To illustrate this we performed an experiment in which we measured the effect of protein S and TFPI on thrombin generation triggered at a high TF concentration in the absence, and presence of APC (Fig. 5.6). The effect of varying concentrations of APC on thrombin generation in protein S- and TFPI-depleted plasma were performed in the absence or presence of $350 \mathrm{nM}$ purified protein $\mathrm{S}$ and/or $0.5 \mathrm{nM}$ TFPI. Thrombin generation was triggered with $13.6 \mathrm{pM} \mathrm{TF}$ and the area under the thrombin generation curve, known as the endogenous thrombin potential (ETP), was used as a measure for thrombin formation.
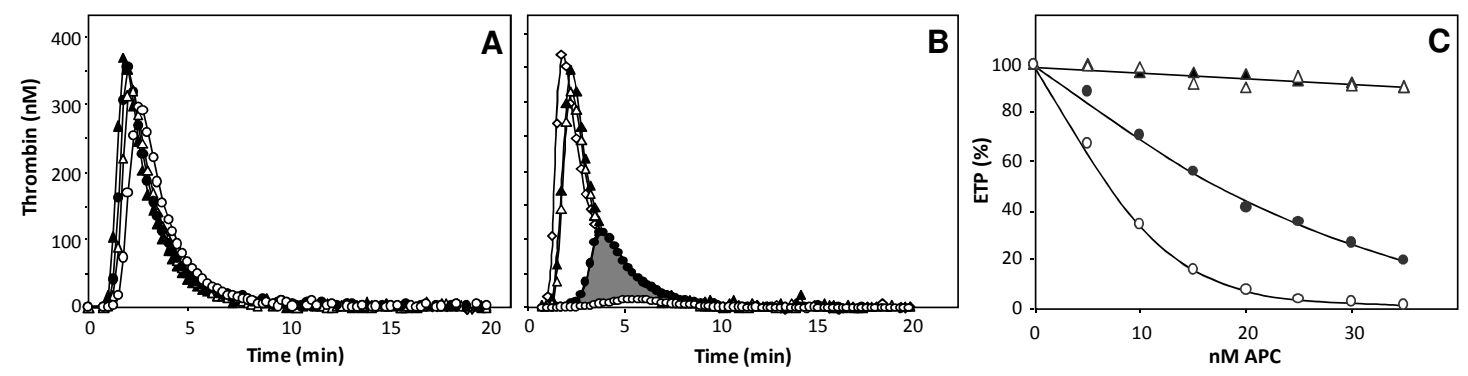

Figure 5.6: Effect of protein $S$ and full length TFPI on thrombin generation in the absence and presence of APC Thrombin generation curves initiated by $13.6 \mathrm{pM}$ TF in the absence of APC (A) or in the presence of $20 \mathrm{nM} \mathrm{APC} \mathrm{(B)} \mathrm{in} \mathrm{protein} \mathrm{S-} \mathrm{and} \mathrm{TFPI-depleted} \mathrm{plasma} \mathrm{(A)} \mathrm{reconstituted} \mathrm{with} 350$ $\mathrm{nM}$ protein $\mathrm{S}(\mathbf{O})$, reconstituted with $0.5 \mathrm{nM}$ full length TFPI $(\triangle)$, or reconstituted with both $350 \mathrm{nM}$ protein $\mathrm{S}$ and $0.5 \mathrm{nM}$ full length TFPI $(O)$. The grey area represents the extra decrease of the ETP by the anticoagulant effect of the TFPI/protein S pathway, in the presence of APC. (C): Effect of APC on the ETP initiated by $13.6 \mathrm{pM}$ TF in protein S- and TFPI-depleted plasma $(\mathbf{\Delta})$ reconstituted with $350 \mathrm{nM}$ protein $\mathrm{S}$ $(\bullet), 0.5 \mathrm{nM}$ full length TFPI $(\triangle)$, or $350 \mathrm{nM}$ protein $S$ and $0.5 \mathrm{nM}$ full length TFPI $(O)$. Averages of duplicate measurements are shown. 
In the absence of APC, thrombin generation was not dependent on the presence of either protein S or TFPI (Fig. 5.6A) and, compared to plasma without protein S and TFPI, was only moderately reduced $(<10 \%)$ when both protein S and TFPI were present in plasma (Fig. 5.6A; open circles). When $20 \mathrm{nM} \mathrm{APC}$ was added to plasma in the absence of protein $\mathrm{S}$ and TFPI, no inhibition of thrombin generation was observed (Fig. 5.6B, filled triangles). This is in line with the observation that the anticoagulant activity of APC in plasma is for more than $95 \%$ dependent on the presence of protein $\mathrm{S}^{29}$. Addition of TFPI to TFPI-depleted plasma did also not reduce the ETP (Fig. 5.6B, open triangles), which indicates that the rapid thrombin generation at high TF in the presence of APC was not effectively controlled by TFPI. However, when protein S was added in the absence of TFPI, the ETP was reduced by $60 \%$ presumably due to the APC-cofactor activity of protein S (Fig. 5.6B, filled circles). The presence of both protein S and TFPI resulted in an additional inhibition of thrombin generation in the presence of protein S and APC due to the extra anticoagulant effect of TFPI, likely in combination with protein S. Together, the protein S/APC and protein S/TFPI pathways inhibit thrombin generation at $20 \mathrm{nM} \mathrm{APC}$ by more than $95 \%$ (Fig. 5.6B, open circles).

Fig. 5.6C shows the effect of varying APC concentrations on the ETP of plasma that did or did not contain TFPI and/or protein S. In line with the data presented in Fig. 5.6 B, APC most effectively inhibits thrombin generation in plasma that contains both TFPI and protein S. 


\section{DISCUSSION.}

In this study we investigated the effects of OC use on the activities of the protein S/TFPI and protein S/protein C anticoagulant pathways in healthy volunteers. We have shown that the use of OC impairs the protein S/TFPI pathway in second generation OC users by lowering full length TFPI levels, and in third generation OC users by lowering both full length TFPI and protein S levels. Our data further indicate that difference in full length TFPI levels, which are much lower in third generation OC users $(34 \mathrm{U} / \mathrm{dl})$ than in second generation OC users $(62 \mathrm{U} / \mathrm{dl})$, also significantly contributes to the more pronounced APC resistance in third generation OC users.

It was previously hypothesized that this discrepancy between protein $\mathrm{S}$ levels and APC-independent anticoagulant activity of protein $\mathrm{S}$ might be caused by modulation of protein $S$ activity by other plasma components that vary in the different populations ${ }^{20}$. This component is now identified as full-length TFPI, and illustrates the importance of protein $\mathrm{S}$ as an anticoagulant cofactor for TFPI in plasma ${ }^{9}$. One of the possible causes for the decreased levels of full-length TFPI with OC-use is the presence of ethinylestradiol in second- and thirdgeneration $\mathrm{OC}^{30}$, which was reported to inhibit endothelial TFPI production ${ }^{19}$. Full-length TFPI levels in plasma are also influenced by age and gender ${ }^{31}$. Women younger than the age of 55 have lower full-length TFPI levels than men of the same age ${ }^{31}$. However, our study did not show significant differences between the levels of full-length TFPI in men and non-OC using women (Table 5.1, Fig. 5.1). This lack of difference is likely caused by the small size of the populations, since in a larger population a significant difference was observed between men and non-OC using women (Chapter 3 )

It was reported that "free" TFPI is the active anticoagulant form of TFPI in plasma, and that "free" TFPI in plasma is most likely the full length TFPI form ${ }^{25}$. In our study we have measured the plasma levels of full length and free TFPI in a population with a wide range of TFPI concentrations and a significant correlation between the two was observed. This supports the hypothesis that free TFPI in fact represents full length TFPI ${ }^{25}$. However, for unknown reasons no levels of free TFPI below $40 \%$ could be measured using the free TFPI ELISA, which might indicate some cross-reactivity of the free TFPI ELISA antibodies with variants other than full length TFPI in plasma.

The APC-independent activity of protein $\mathrm{S}^{29}$, which was later identified as TFPIcofactor activity ${ }^{9}$ is only observed at low tissue factor concentrations ${ }^{9,29}$. This is most likely explained by the fact that TFPI is a slow tight binding inhibitor which in conjunction with 
protein $\mathrm{S}$, is only able to effectively inhibit slow onset extrinsic activation of coagulation. Plasma levels of TFPI and protein S are not only important for the activity of the TFPI pathway, but both proteins are also the main determinants of the thrombin generation-based APCresistance test ${ }^{15}$. That protein $\mathrm{S}$ is a determinant is not surprising, as APC-activity in plasma is for more than $95 \%$ dependent on the presence of (free) protein $S^{29}$. However, the dependence of the APC-resistance test on TFPI is less obvious as the tissue factor concentration used for the nAPC-sr measurement is relatively high. This makes thrombin generation less dependent on protein S/TFPI anticoagulant activity, unless in the presence of APC a slow onset coagulation is achieved that is comparable to the initiation with low tissue factor concentrations. In Fig. 6 we presented an experiment that shows that not only protein $S$, but also TFPI plays an important role in the expression of anticoagulant activity of APC. It appears that $20 \mathrm{nM} \mathrm{APC}$ does neither inhibit thrombin generation in combined protein S-TFPI deficient plasma nor in protein S-TFPI deficient plasma reconstituted with a normal level of full length TFPI (Fig. 5.6 B,C). Supplementation of the protein S-TFPI deficient plasma with a physiological amount of protein S $(350 \mathrm{nM})$ decreased the ETP determined in the presence of APC $\left(\right.$ ETP $\left._{\text {+APC }}\right)$ to $\sim 45 \%$ of that observed in the absence of protein S (Fig. 5.6C). In plasma that contained $0.5 \mathrm{nM}$ full length TFPI, protein S reduced the ETP ${ }_{+A P C}$ to $~ 7 \%$ of that observed in the absence of protein S. Thus, despite the high TF concentration used in the thrombin generation-based APC resistance test, the presence of TFPI is necessary for optimal expression of the activity of the protein S-protein C system.

The current paper shows that the activity of both the protein S/TFPI and the $\mathrm{APC} /$ protein S pathway are decreased during OC use ${ }^{32}$. Women using OC have an increased risk for developing venous thrombosis. However, it remains to be established, whether the impaired activity of the protein S/TFPI pathway in pill users contributes to the increased thrombosis risk associated with $O C$ use. 


\section{REFERENCES}

1. Walker FJ. Regulation of activated protein C by protein S. The role of phospholipid in factor Va inactivation. J Biol Chem. 1981;256:11128-11131.

2. Koedam JA, Meijers JC, Sixma JJ, Bouma BN. Inactivation of human factor VIII by activated protein C. Cofactor activity of protein $\mathrm{S}$ and protective effect of von Willebrand factor. J Clin Invest. 1988;82:1236-1243.

3. Shen L, Dahlback B. Factor $\mathrm{V}$ and protein $\mathrm{S}$ as synergistic cofactors to activated protein $\mathrm{C}$ in degradation of factor VIIla. J Biol Chem. 1994;269:18735-18738.

4. Kalafatis $M$, Rand MD, Mann KG. The mechanism of inactivation of human factor $V$ and human factor Va by activated protein C. J Biol Chem. 1994;269:31869-31880.

5. Suzuki K, Stenflo J, Dahlback B, Teodorsson B. Inactivation of human coagulation factor $\mathrm{V}$ by activated protein C. J Biol Chem. 1983;258:1914-1920.

6. Solymoss S, Tucker MM, Tracy PB. Kinetics of inactivation of membrane-bound factor Va by activated protein C. Protein S modulates factor Xa protection. J Biol Chem. 1988;263:14884-14890.

7. Rosing J, Hoekema L, Nicolaes GA, et al. Effects of protein S and factor Xa on peptide bond cleavages during inactivation of factor Va and factor VaR506Q by activated protein C. J Biol Chem. 1995;270:27852-27858.

8. Maurissen LF, Thomassen MC, Nicolaes GA, et al. Re-evaluation of the role of the protein S-C4b binding protein complex in activated protein C-catalyzed factor Va-inactivation. Blood. 2008;111:3034-3041.

9. Hackeng TM, Sere KM, Tans G, Rosing J. Protein S stimulates inhibition of the tissue factor pathway by tissue factor pathway inhibitor. Proc Natl Acad Sci U S A. 2006;103:3106-3111.

10. Broze GJ, Jr., Girard TJ, Novotny WF. Regulation of coagulation by a multivalent Kunitz-type inhibitor. Biochemistry. 1990;29:7539-7546.

11. Girard TJ, Warren LA, Novotny WF, et al. Functional significance of the Kunitz-type inhibitory domains of lipoprotein-associated coagulation inhibitor. Nature. 1989;338:518-520.

12. Huang ZF, Wun TC, Broze GJ, Jr. Kinetics of factor Xa inhibition by tissue factor pathway inhibitor. J Biol Chem. 1993;268:26950-26955.

13. Rosing J, Tans G, Nicolaes GA, et al. Oral contraceptives and venous thrombosis: different sensitivities to activated protein $C$ in women using second- and third-generation oral contraceptives. Br J Haematol. 1997;97:233-238.

14. Tans G, Curvers J, Middeldorp S, et al. A randomized cross-over study on the effects of levonorgestrel- and desogestrel-containing oral contraceptives on the anticoagulant pathways. Thromb Haemost. 2000;84:15-21.

15. de Visser MC, van Hylckama Vlieg A, Tans G, et al. Determinants of the APTT- and ETP-based APC sensitivity tests. J Thromb Haemost. 2005;3:1488-1494.

16. Tans G, van Hylckama Vlieg A, Thomassen MC, et al. Activated protein $C$ resistance determined with a thrombin generation-based test predicts for venous thrombosis in men and women. $\mathrm{Br} J$ Haematol. 2003;122:465-470. 
17. Harris GM, Stendt CL, Vollenhoven BJ, Gan TE, Tipping PG. Decreased plasma tissue factor pathway inhibitor in women taking combined oral contraceptives. Am J Hematol. 1999;60:175180 .

18. Simmonds RE, Ireland H, Lane DA, Zoller B, Garcia de Frutos P, Dahlback B. Clarification of the risk for venous thrombosis associated with hereditary protein $\mathrm{S}$ deficiency by investigation of a large kindred with a characterized gene defect. Ann Intern Med. 1998;128:8-14.

19. Dahm A, Rosendaal FR, Andersen TO, Sandset PM. Tissue factor pathway inhibitor anticoagulant activity: risk for venous thrombosis and effect of hormonal state. Br J Haematol. 2006;132:333338.

20. Koenen RR, Christella M, Thomassen LG, Tans G, Rosing J, Hackeng TM. Effect of oral contraceptives on the anticoagulant activity of protein $\mathrm{S}$ in plasma. Thromb Haemost. 2005;93:853-859.

21. Rosing J, Bakker HM, Thomassen MC, Hemker HC, Tans G. Characterization of two forms of human factor Va with different cofactor activities. J Biol Chem. 1993;268:21130-21136.

22. Hemker HC, Wielders S, Kessels $\mathrm{H}$, Beguin S. Continuous registration of thrombin generation in plasma, its use for the determination of the thrombin potential. Thromb Haemost. 1993;70:617624.

23. Nordfang O, Bjorn SE, Valentin S, et al. The C-terminus of tissue factor pathway inhibitor is essential to its anticoagulant activity. Biochemistry. 1991;30:10371-10376.

24. Wesselschmidt R, Likert K, Girard T, Wun TC, Broze GJ, Jr. Tissue factor pathway inhibitor: the carboxy-terminus is required for optimal inhibition of factor Xa. Blood. 1992;79:2004-2010.

25. Dahm AE, Andersen TO, Rosendaal F, Sandset PM. A novel anticoagulant activity assay of tissue factor pathway inhibitor I (TFPI). J Thromb Haemost. 2005;3:651-658.

26. Koenen RR, Tans G, van Oerle R, Hamulyak K, Rosing J, Hackeng TM. The APC-independent anticoagulant activity of protein $\mathrm{S}$ in plasma is decreased by elevated prothrombin levels due to the prothrombin G20210A mutation. Blood. 2003;102:1686-1692.

27. Hemker HC, Al Dieri R, De Smedt E, Beguin S. Thrombin generation, a function test of the haemostatic-thrombotic system. Thromb Haemost. 2006;96:553-561.

28. Dielis AW, Castoldi E, Spronk HM, et al. Coagulation factors and the protein C system as determinants of thrombin generation in a normal population. J Thromb Haemost. 2008;6:125-131.

29. Sere KM, Rosing J, Hackeng TM. Inhibition of thrombin generation by protein $\mathrm{S}$ at low procoagulant stimuli: implications for maintenance of the hemostatic balance. Blood. 2004;104:3624-3630.

30. Rosendaal FR, Helmerhorst FM, Vandenbroucke JP. Female hormones and thrombosis. Arterioscler Thromb Vasc Biol. 2002;22:201-210.

31. Ariens RA, Coppola R, Potenza I, Mannucci PM. The increase with age of the components of the tissue factor coagulation pathway is gender-dependent. Blood Coagul Fibrinolysis. 1995;6:433437.

32. van Vliet $H A$, Bertina RM, Dahm $A E$, et al. Different effects of oral contraceptives containing different progestogens on protein $S$ and tissue factor pathway inhibitor. J Thromb Haemost. 2008;6:346-351. 



\section{Chapter 6}

\section{General discussion}





\section{APC COFACTOR ACTIVITY OF PROTEIN S}

Ever since the anticoagulant activity of protein S was described in $1980{ }^{1}$, different mechanisms of action have been attributed to this protein. The best known and most studied function of protein $\mathrm{S}$ is its ability to act as a non-enzymatic cofactor of APC in APC-mediated inactivation of coagulation factors $\mathrm{Va}$ and VIIIa ${ }^{2,3}$. In factor Va, protein S enhances the APCmediated cleavage at $\mathrm{R}^{306}$ approximately 20 -fold, whereas protein $\mathrm{S}$ has only relatively little effect on the cleavage at $\mathrm{R}^{5064}$. It was reported that only free protein $\mathrm{S}$ functions as a cofactor for $A P C$, and that $\mathrm{C} 4 \mathrm{~b}$-binding protein (C4BP), which forms a tight 1:1 complex with protein $\mathrm{S}$, inhibited the APC-cofactor activity of protein $S^{5}$. However, work presented in this thesis shows that the protein S-C4BP complex expresses APC-cofactor activity and stimulates the APC-mediated cleavage at $\mathrm{R}^{306} 10$-fold. This was shown in model systems using purified proteins and in plasma that both contained factor $V_{\text {Leiden. }}$. Protein S-C4BP stimulated APCmediated inactivation factor $\mathrm{Va}_{\text {Leiden, }}$, which lacks the cleavage site at $\mathrm{R}^{506}$ due to a mutation in the factor $V$ gene ${ }^{6}$, approximately 10 -fold. When the APC-mediated inactivation of factor $\mathrm{V}_{\text {Leiden }}$ was compared to inactivation of normal factor $\mathrm{Va}$ in the presence of protein $\mathrm{S}$, the latter was apparently inhibited by the addition of C4BP, confirming previous reports in which it was shown that C4BP inhibits the APC-cofactor activity of protein $\mathrm{S}^{5}$. However, detailed analysis of time courses of factor Va inactivation showed that APC-mediated proteolysis at $R^{306}$ was still enhanced by protein S-C4BP but, that the protein S-C4BP complex specifically inhibited APCmediated proteolysis at $\mathrm{R}^{506}$.

Inhibition of the APC-mediated cleavage at $\mathrm{R}^{506}$ by protein S-C4BP creates a situation in which the initial rate of inactivation of factor Va by APC is decreased. These observations explain why the addition of C4BP to plasma reduced the clotting time determined in the presence of APC ${ }^{5,7}$. In 1986, it was already observed that when C4BP was immunoabsorbed in normal plasma, clotting times were prolonged in the presence of APC ${ }^{5}$ (Fig 6.1). The observation that APC performs better when protein S-C4BP is removed from plasma can now be explained by the selective removal of a specific inhibitor of APC-mediated cleavage at $\mathrm{R}^{506}$ in factor Va. 


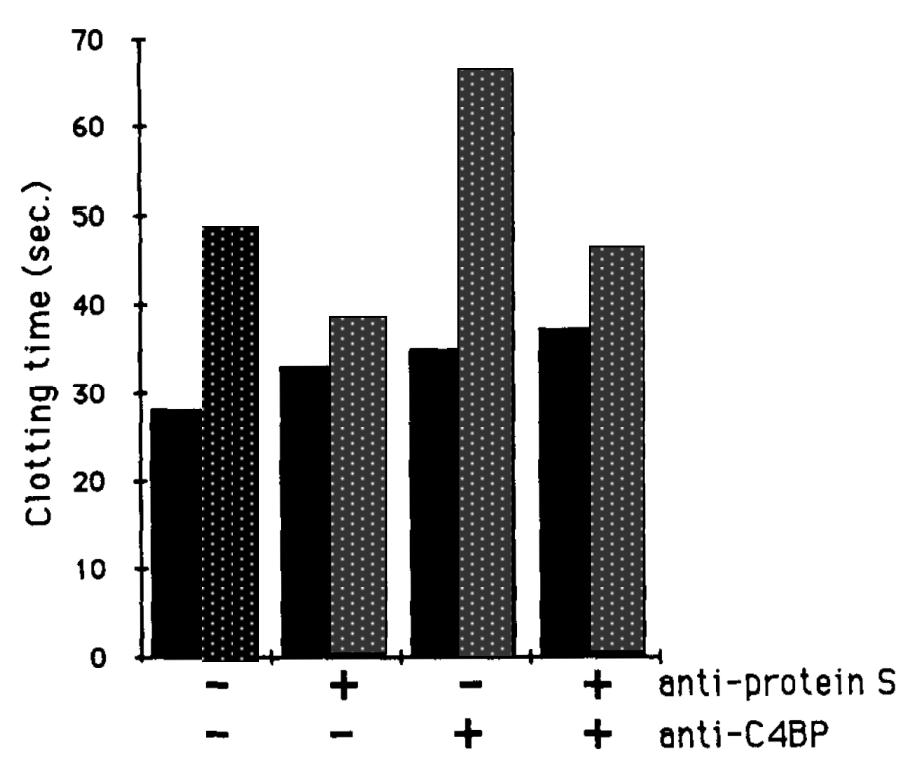

Figure 6.1: Effects of immunoadsorption of human plasma Protein S, or C4BP, on APCinduced prolongation of clotting time. Human plasma was depleted of protein $S$ and/or C4BP by fluid-phase immunoprecipitation. The clotting time were measured in a factor Xa assay without (solid columns) or with (dotted columns) added APC (at a final concentration of $1.25 \mu \mathrm{g} / \mathrm{ml}$ in the assay. (Figure taken from Dahlbäck B et al, JBC, 1986; 261:12022-7.)

\section{TFPI COFACTOR ACTIVITY OF PROTEIN S}

In literature two assays for measuring the APC-independent activities of protein $\mathrm{S}$ in plasma were described, which were both based on determining clotting times in the presence or absence of antibodies against protein $S^{8,9}$. Both tests were performed under conditions at which the clotting times of plasma were prolonged by either the addition of heparin ${ }^{8}$ or initiation of coagulation with low concentrations of factor $\mathrm{Xa}{ }^{9}$. The APC-independent activity of protein $\mathrm{S}$ was also observed in thrombin generation assays in plasma in which low concentrations of tissue factor were used for initiation of coagulation ${ }^{10}$. Initially it was proposed that the anticoagulant effect of protein $S$ in plasma was caused by interfering with generation or activity of the prothrombinase complex, but later it was explained by the TFPIcofactor activity of protein $\mathrm{S}^{11}$.

Protein $\mathrm{S}$ stimulates the down-regulation of thrombin formation by TFPI through promoting the inhibition of FXa by TFPI ${ }^{11}$. All APC-independent activities of protein $S$ observed in plasma to date can be ascribed to the TFPI-cofactor activity of protein S. Because the inhibition of the extrinsic coagulation pathway by TFPI/protein $\mathrm{S}$ is only observed at a low concentration of initiator (TF) ${ }^{10,12,13}$, or under conditions at which clotting times are prolonged 
8,9 , a slow onset coagulation reactions is crucial for detection of the anticoagulant activity of the TFPI/protein S system.

We described a thrombin generation-based assay that enables quantification of the TFPI-cofactor activity of protein $S$ and of the overall anticoagulant activity of the TFPI/protein $S$ pathway in plasma. Low TF concentrations were chosen based on desired peak heights of thrombin generation in normal pooled plasma without addition of antibodies ( $~ 40 \mathrm{nM}$ thrombin), which enables optimal measurement of the anticoagulant activity of the TFPI/protein S pathway ${ }^{10,11}$. Anticoagulant activities of the TFPI/protein S pathway and TFPIcofactor activity of protein $\mathrm{S}$ were expressed as ratios of peak heights of thrombin generation curves determined with and without addition of antibodies against protein S (protein S ratio) or TFPI (TFPI ratio), respectively. The protein S-ratio of normal pooled plasma was $\sim 0.5$ and the TFPI-ratio was $\sim 0.25$ (Fig 6.2A). However, limitations of the assay have to be mentioned. In some plasma samples, thrombin generation at low TF concentrations in the absence of antibodies is that low that the peak heights of thrombin generation and hence, protein S- and TFPI ratios cannot be reliably calculated.
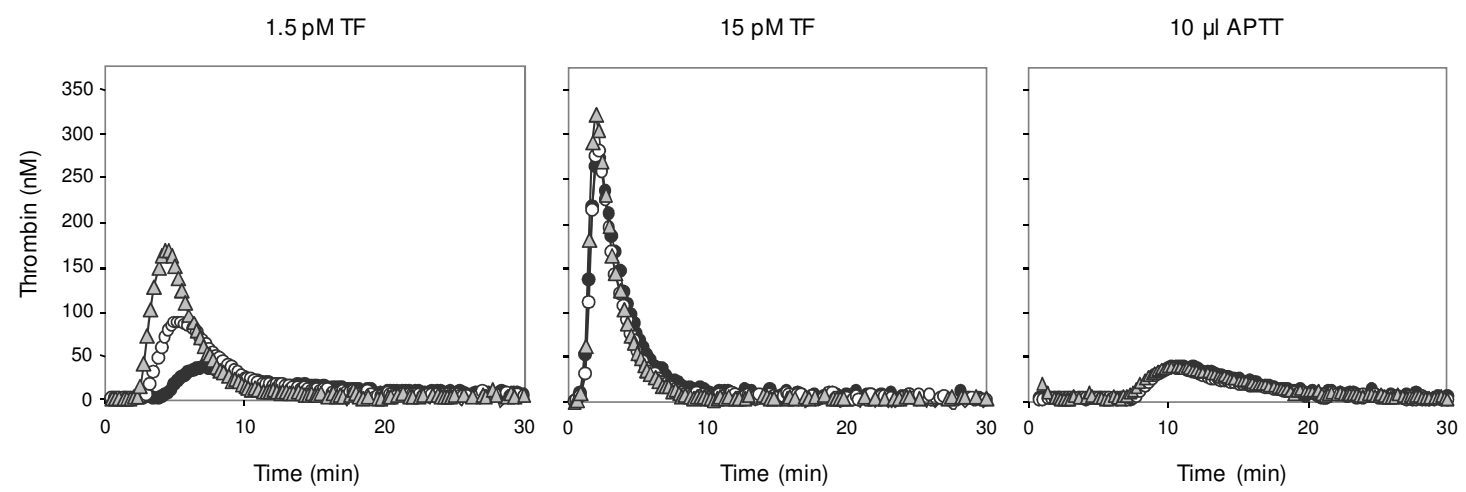

Figure 6.2:TFPI-cofactor activity of protein S. Thrombin generation in recalcified citrated plasma was continuously followed with fluorogenic substrate I-1140 (Z-Gly-Gly-Arg-AMC.HCl) in the presence of $4 \mu \mathrm{M}$ phospholipid vesicles and $16 \mathrm{mM} \mathrm{CaCl}_{2}$ (final concentrations) in the absence $(\bullet)$ or presence (०) of inhibitory polyclonal antibodies against protein $S$ or monoclonal antibodies against TFPI ( $\triangle$ ). A: Thrombin generation in normal pooled plasma was initiated with $1.5 \mathrm{pM}$ TF concentration in the presence of $30 \mu \mathrm{g} / \mathrm{ml}$ corn trypsin inhibitor (CTI). B: Thrombin generation in NPP was initiated with $15 \mathrm{pM}$ TF concentration in the presence of $30 \mu \mathrm{g} / \mathrm{ml} \mathrm{CTI}$. C: Thrombin generation was initiated in NPP with $10 \mu \mathrm{l}$ APTT reagent. (Figure adjusted from Castoldi E and Hackeng TM, Curr. Opin. Haematol; 2008;15:529-36).

At high TF concentrations the effect of anticoagulant activity of the TFPI/protein S pathway was not observed ${ }^{10}$. This is due to the fact that the amount of factor Xa that escapes 
regulation by TFPI is linearly proportional with the TF concentration ${ }^{12}$ and indicates that at increasing amounts of TF, TFPI will ultimately fail to keep the factor Xa concentration below the threshold required for prothrombin activation and thrombin generation ${ }^{13}$ (Fig $6.2 \mathrm{~B}$ ).

Also when coagulation was initiated through the intrinsic pathway no TPFI-cofactor activity of protein S was observed (Fig $6.2 \mathrm{C}$ ) ${ }^{14}$. A possible explanation is that factor Xa that is generated by the factor IXa/factor VIIla complex on the surface of activated platelets ${ }^{15}$, is directly translocated to factor $\mathrm{Va}$ on the same platelet to form the prothrombinase complex ${ }^{16,17}$, and hence is insensitive to (escapes) inhibition by TFPI. This possibility is supported by the observation that physiological concentrations of TFPI do not inhibit prothrombinase ${ }^{18}$. In contrast, factor Xa that is formed by TF/factor VIla likely has to travel from the site of tissue damage to the surface of activated platelets in order to assemble into the prothrombinase complex. This "free" factor Xa on its turn would then be prone to inhibition by TFPI and protein S, explaining the observed TFPI-cofactor activity of protein S under these conditions ${ }^{19}$. The precise mechanisms via which factor $\mathrm{Xa}$ is inhibited and thrombin generation is downregulated by TFPI and protein $\mathrm{S}$ needs further investigation.

The thrombin generation-based assay was developed to assess the TFPI-cofactor activity of protein $\mathrm{S}$ and the total TFPI/protein S anticoagulant activity in plasma. In order to validate these assays the anticoagulant activity of the TFPI/protein S pathway was investigated in different populations. In a normal population, levels of protein S and TFPI were determined as well as the TFPI-cofactor activity of protein S. Remarkably, the levels of neither free nor total protein S correlated with the TFPI-cofactor activity of protein S. However, the TFPI-cofactor activity of protein $S$ did correlate with the levels of TFPI in plasma, demonstrating a direct link between the inhibitor and its cofactor.

The clinical relevance of the TFPI/protein S system was further investigated in heterozygous protein S-deficient families. In contrast to the normal family members, in the protein S-deficient individuals the TFPI-cofactor activity of protein S depended on the plasma level of protein S (fig 3.7A) i.e. low levels of protein S correlated with low TFPI-cofactor activity of protein S. One of the possibilities for the absence of a correlation between protein $\mathrm{S}$ levels and protein S activity in the normal population may be saturation of TFPI by protein $\mathrm{S}$ in the range of protein $\mathrm{S}$ concentrations present in normal plasmas. At saturating conditions, fluctuations of protein S concentrations will not affect its TFPI-cofactor activity. This possibility is supported by the observation that when protein $\mathrm{S}$ is reduced like in protein S-deficient individuals, the TFPI-cofactor activity of protein $\mathrm{S}$ becomes dependent of the protein $\mathrm{S}$ concentration. 
In the line with recent observations ${ }^{20}$, heterozygous protein S-deficient type I individuals have also low levels of full length TFPI. This means that the association of low levels of protein $\mathrm{S}$ and low levels of TFPI may aggravate the hypercoagulable state of protein S-deficient patients and underscore the importance of a functional TFPI/protein S pathway.

The fact that plasma levels of protein S and full length TFPI are associated suggests that heterozygous protein S-deficient individuals automatically have low levels of full length TFPI. However, this is not the case in type III protein $\mathrm{S}$ heterozygous individuals. These have normal levels of total protein $S$ and low levels of free protein $S$, but have levels of full length TFPI similar to their normal family members. An explanation for the association between levels of TFPI and protein $S$ is not available. The protein $S$ and TFPI genes are not transcribed by the same promotor due to the location of genes on different chromosomes ${ }^{21,22}$. However, TFPI and part of the protein S circulating in plasma are synthesized by endothelial cells ${ }^{23,24}$ and general effects on protein synthesis within these cells may reflect on the expression of both proteins.

Since protein $\mathrm{S}$ is a cofactor for APC and for TFPI, a correlation between the nAPC-sr and the TFPI-ratio, which is a measurement for the overall activity of the TFPI/protein S system, was found both in heterozygous protein S-deficient patients and in their non-deficient family members (Fig 4.5). From literature it is known that protein S and TFPI are the major determinants for the ETP-based APC sensitivity test ${ }^{25,26}$. As the activity of the TFPI/protein S pathway is only observed at low tissue factor concentrations, it was not expected that TFPI is a determinant of the nAPC-sr, which is measured at a high TF concentration. However, when APC is added to plasma, a situation is created at which slow coagulation is achieved analogous to initiation with low concentrations of TF (Fig. 5.6). Under these conditions protein $S$ expresses its dual cofactor activities and inhibits thrombin generation by promoting the inhibition of factor Xa by TFPI ${ }^{11}$, and by stimulating the inactivation of factor Va and factor VIIla by APC ${ }^{27,28}$.

This dual cofactor activity of protein $\mathrm{S}$ is also observed in plasma of women using oral contraceptives. Pill-using women did not only show an elevated APC-sr ${ }^{29}$ but also a reduced TFPI-cofactor activity of protein $S^{29}$ (chapter 5). The high APC-sr and the reduced TFPIcofactor activity of protein $\mathrm{S}$ in third generation $\mathrm{OC}$ users is at least partially due to low levels of TFPI and protein S, whereas in second generation OC users, who appear to have normal levels of protein S, low TFPI levels contribute to APC resistance and lower pSR (Fig 5.3B) are largely due to decreased TFPI levels. 
We propose that a reduced anticoagulant activity of the TFPI/protein S pathway 1 ) explains why TFPI is an important determinant of the APCsr ${ }^{25,26}$, and 2) contributes to the pronounced APC resistance and the increased risk of venous thrombosis in women who use OC.

In conclusion: the physiological relevance of the TFPI-cofactor activity of protein $\mathrm{S}$ and TFPI/protein $\mathrm{S}$ anticoagulant activity in plasma was assessed in different populations. In heterozygous protein S-deficient patients and in women using oral contraceptives, the TFPI/protein S anticoagulant activity was significantly reduced. We propose that this impairment of the TFPI/protein S pathway, either caused by a genetic or by an acquired defect, contributes to the increased risk for venous thrombosis found in these populations.

\section{FUTURE PERSPECTI VES.}

In this thesis we reported that the protein S-C4BP complex acts as a cofactor for APC both in a model system containing purified components and in plasma. Until now, little is known about the TFPI-cofactor activity of protein $\mathrm{S}$ and specifically the cofactor activity of the protein S-C4BP complex. So far it has been described that the protein S-C4BP complex showed reduced cofactor activity for TFPI in plasma ${ }^{11}$. However, further experiments to study the TFPI-cofactor activity of protein S-C4BP in a model system as well as in plasma are of interest.

In contrast to protein $\mathrm{S}$ cleaved by factor $\mathrm{Xa}$, protein $\mathrm{S}$ cleaved by thrombin shows no APC-independent anticoagulant activity in a model system ${ }^{30}$. Also here it will be interesting to investigate whether thrombin- and factor Xa-cleaved forms of protein S has TFPI-cofactor activity in a model system and in plasma.

Dahm reported that levels of protein S covariate with levels of TFPI ${ }^{20}$. We showed that this observation extends to plasma of heterozygous protein $S$ deficient individuals and of women using oral contraceptives (chapter 3,4 and 5). As discussed above, protein S and TFPI are both synthesized by endothelial cells ${ }^{23,24}$ and further investigation about the co-variation and possible interaction between these proteins are necessary.

TFPI does not only show a co-variation with protein $S$, but a recent study has reported that the level of factor $V$ also correlates with the level of TFPI in a population of patients with severe or partial factor $V$ deficiency and their family members. Binding studies using surface plasmon resonance showed that factor $V$ binds to immobilized TFPI suggesting complex 
formation in plasma ${ }^{31}$. Similar approaches will be useful in the future to demonstrate a direct interaction between protein S and TFPI. This will not only important to unravel the mechanism of the TFPI-cofactor activity of protein $\mathrm{S}$, but is also essential to understand the co-variation of protein S and TFPI in plasma. 


\section{REFERENCES}

1. Walker FJ. Regulation of activated protein $\mathrm{C}$ by a new protein. A possible function for bovine protein S. J Biol Chem. 1980;255:5521-5524.

2. Walker FJ, Sexton PW, Esmon CT. The inhibition of blood coagulation by activated Protein C through the selective inactivation of activated Factor V. Biochim Biophys Acta. 1979;571:333-342.

3. Vehar GA, Davie EW. Preparation and properties of bovine factor VIII (antihemophilic factor). Biochemistry. 1980;19:401-410.

4. Rosing J, Hoekema L, Nicolaes GA, et al. Effects of protein S and factor Xa on peptide bond cleavages during inactivation of factor Va and factor VaR506Q by activated protein C. J Biol Chem. 1995;270:27852-27858.

5. Dahlback B. Inhibition of protein Ca cofactor function of human and bovine protein S by C4bbinding protein. J Biol Chem. 1986;261:12022-12027.

6. Bertina RM, Koeleman BP, Koster $\mathrm{T}$, et al. Mutation in blood coagulation factor $\mathrm{V}$ associated with resistance to activated protein C. Nature. 1994;369:64-67.

7. Nishioka J, Suzuki K. Inhibition of cofactor activity of protein S by a complex of protein S and C4bbinding protein. Evidence for inactive ternary complex formation between protein S, C4b-binding protein, and activated protein C. J Biol Chem. 1990;265:9072-9076.

8. van Wijnen M, van 't Veer C, Meijers JC, Bertina RM, Bouma BN. A plasma coagulation assay for an activated protein C-independent anticoagulant activity of protein S. Thromb Haemost. 1998;80:930-935.

9. Koenen RR, Tans G, van Oerle R, Hamulyak K, Rosing J, Hackeng TM. The APC-independent anticoagulant activity of protein $\mathrm{S}$ in plasma is decreased by elevated prothrombin levels due to the prothrombin G20210A mutation. Blood. 2003;102:1686-1692.

10. Sere KM, Rosing J, Hackeng TM. Inhibition of thrombin generation by protein $S$ at low procoagulant stimuli: implications for maintenance of the hemostatic balance. Blood. 2004;104:3624-3630.

11. Hackeng TM, Sere KM, Tans G, Rosing J. Protein S stimulates inhibition of the tissue factor pathway by tissue factor pathway inhibitor. Proc Natl Acad Sci U S A. 2006;103:3106-3111.

12. Baugh RJ, Broze GJ, Jr., Krishnaswamy S. Regulation of extrinsic pathway factor Xa formation by tissue factor pathway inhibitor. J Biol Chem. 1998;273:4378-4386.

13. Hockin MF, Jones KC, Everse SJ, Mann KG. A model for the stoichiometric regulation of blood coagulation. J Biol Chem. 2002;277:18322-18333.

14. Castoldi E, Hackeng TM. Regulation of coagulation by protein S. Curr Opin Hematol. 2008;15:529536.

15. Gailani D, Broze GJ, Jr. Factor XI activation in a revised model of blood coagulation. Science. 1991;253:909-912.

16. Rosing J, Tans G, Govers-Riemslag JW, Zwaal RF, Hemker HC. The role of phospholipids and factor Va in the prothrombinase complex. J Biol Chem. 1980;255:274-283.

17. Krishnaswamy S, Nesheim ME, Pryzdial EL, Mann KG. Assembly of prothrombinase complex. Methods Enzymol. 1993;222:260-280. 
18. Mast AE, Broze GJ, Jr. Physiological concentrations of tissue factor pathway inhibitor do not inhibit prothrombinase. Blood. 1996;87:1845-1850.

19. Ndonwi M, Broze G, Jr. Protein S enhances the tissue factor pathway inhibitor inhibition of factor Xa but not its inhibition of factor VIla-tissue factor. J Thromb Haemost. 2008;6:1044-1046.

20. Dahm AE, Sandset PM, Rosendaal FR. The association between protein S levels and anticoagulant activity of tissue factor pathway inhibitor type 1. J Thromb Haemost. 2008;6:393-395.

21. Ploos van Amstel HK, Reitsma PH, van der Logt CP, Bertina RM. Intron-exon organization of the active human protein S gene PS alpha and its pseudogene PS beta: duplication and silencing during primate evolution. Biochemistry. 1990;29:7853-7861.

22. Girard TJ, Eddy R, Wesselschmidt RL, et al. Structure of the human lipoprotein-associated coagulation inhibitor gene. Intro/exon gene organization and localization of the gene to chromosome 2. J Biol Chem. 1991;266:5036-5041.

23. Fair DS, Marlar RA, Levin EG. Human endothelial cells synthesize protein S. Blood. 1986;67:11681171.

24. Bajaj MS, Kuppuswamy MN, Saito H, Spitzer SG, Bajaj SP. Cultured normal human hepatocytes do not synthesize lipoprotein-associated coagulation inhibitor: evidence that endothelium is the principal site of its synthesis. Proc Natl Acad Sci U S A. 1990;87:8869-8873.

25. de Visser MC, van Hylckama Vlieg A, Tans G, et al. Determinants of the APTT- and ETP-based APC sensitivity tests. J Thromb Haemost. 2005;3:1488-1494.

26. Dielis AW, Castoldi E, Spronk HM, et al. Coagulation factors and the protein C system as determinants of thrombin generation in a normal population. J Thromb Haemost. 2008;6:125-131.

27. Walker FJ. Protein $S$ and the regulation of activated protein C. Semin Thromb Hemost. 1984;10:131-138.

28. Koedam JA, Meijers JC, Sixma JJ, Bouma BN. Inactivation of human factor VIII by activated protein C. Cofactor activity of protein $\mathrm{S}$ and protective effect of von Willebrand factor. J Clin Invest. 1988;82:1236-1243.

29. Koenen RR, Christella M, Thomassen LG, Tans G, Rosing J, Hackeng TM. Effect of oral contraceptives on the anticoagulant activity of protein $S$ in plasma. Thromb Haemost. 2005;93:853-859.

30. Heeb MJ, Griffin JH. Activated protein C-dependent and -independent anticoagulant activities of protein S have different structural requirements. Blood Cells Mol Dis. 2002;29:190-199

31. Duckers $C$, Simioni $P$, Spieza et al. Low plasma levels of tissue factor pahtway inhibitor in patients with congenital factor $V$ deficiency. Blood 2008; 112: 3615-3623 



\section{SUMMARY}

Blood coagulation also called haemostasis proceeds via a complex process which is initiated when the blood vessel wall is damaged and tissue factor (TF) is exposed to the flowing blood. TF exposure triggers the coagulation cascade which finally results in the formation of thrombin, the conversion of fibrinogen into fibrin and the formation of a blood clot. Under normal conditions, no coagulation occurs. In vivo the coagulation process is regulated by circulating anticoagulant proteins that prevent excessive clot formation and a limited clot formation to the site of vascular injury.

One of these anticoagulant proteins is protein $\mathrm{S}$. Protein $\mathrm{S}$ is a vitamin $\mathrm{K}$ dependent protein which circulates free $(40 \%)$ and bound to C4BP (60\%) in plasma. Protein S expresses cofactor activity for APC by enhancing the APC-catalyzed proteolysis at $\mathrm{R}^{306}$ in factor Va. It is generally accepted that only free protein $\mathrm{S}$ is active, and that complex formation with $\mathrm{C} 4 \mathrm{~b}$ binding protein (C4BP) inhibits the APC-cofactor activity of protein S. However, in chapter 2 we show that the protein S-C4BP complex expresses APC-cofactor activity, and stimulates APC-catalyzed cleavage at $R^{306}$ more than 10 -fold, but inhibits cleavage of the peptide bond at $\mathrm{R}^{506}$ by APC 3- to 4 -fold. In comparison, protein $S$ stimulates APC-catalyzed cleavage at $\mathrm{R}^{306}$ $\sim 20$-fold, and has no or a minor stimulatory effect on the cleavage at $\mathrm{R}^{506}$. The overall effect of the protein S-C4BP complex on the inactivation of factor Va by APC is 7-fold less than that of free protein S. This difference is not caused by a reduced APC-cofactor activity of the protein S-C4BP complex in APC-catalyzed cleavage at $R^{306}$, but by inhibition of APC-mediated proteolysis at $\mathrm{R}^{506}$ of factor $\mathrm{Va}$. These observations are of particular interest for carriers of the factor $V_{\text {Leiden }}$ mutation $\left(R^{506} \mathrm{Q}\right)$, as protein S-C4BP effectively enhances APC-catalyzed factor $\mathrm{Va}$ $\left(\mathrm{R}^{306}\right)$ inactivation in plasma containing factor $\mathrm{V}_{\text {Leiden }}$ (Chapter 2).

Protein $\mathrm{S}$ also expresses anticoagulant activity in the absence of APC (APCindependent activity). Recently, our laboratory reported that protein S stimulates the downregulation of thrombin formation by full length TFPI i.e. acts as a cofactor of TFPI. We have developed two functional test for the determination of activity of the TPFI/protein S system in plasma (Chapter 3). The activity of the TFPI/protein S system in plasma was measured by determining thrombin generation in the absence and presence of neutralizing antibodies against protein S or TFPI. In both assays calibrated automated thrombography (CAT) was used to measure thrombin generation curves. The assay performance was first examined in plasma samples from 85 normal individuals collected at the university Maastricht. The ratio of thrombin peaks determined in the absence and presence of anti-protein $\mathrm{S}$ antibodies (protein 
S-ratio) which was 0.5 in normal pooled plasma is a measure of the TFPI-cofactor activity of protein $\mathrm{S}$. The ratio of the thrombin peaks determined in plasma which did or did not contain antibodies directed against TFPI is a measure for the efficacy via which the TFPI/protein S system down-regulates thrombin generation. The TFPI-ratio of normal plasma was around 0.25 which means that thrombin generation in plasma is reduced $75 \%$ due to the TFPI/protein S system. Protein S- and TFPI-ratios were also measured in 35 members of protein S deficient families obtained from Italy. Both ratios were significantly higher in patients who were heterozygous for type-I protein $\mathrm{S}$ deficiency than in their non-affected family members. The protein S- and TFPI-ratios correlated well with full-length TFPI levels determined by a newly developed ELISA and only correlated with protein $S$ levels in the protein S-deficient individuals. Impairment of the TFPI/protein S system might contribute to an increased risk on venous thrombosis in these protein S-deficient individuals (Chapter 3).

The cofactor activity of protein S for APC and TFPI was also investigated in a much larger population of heterozygous protein S-deficient patients (Chapter 4). Epidemiological, genetic and functional studies were performed in protein S-deficient families in order to evaluate the thrombosis risk associated with type I and type III protein S deficiencies. Type I protein $\mathrm{S}$ deficiency is characterized by low total and low free antigen levels and type III deficient individuals have normal total and low free antigen levels of protein S. Kaplan-Meier analysis in 242 individuals belonging to 30 families showed that the exposure of type I and III protein $\mathrm{S}$ deficient individuals to thrombosis is similar. From the population used for KaplanMeier analysis, 23 families (132 individuals) were further characterized to explain this finding. In these families 11 PROS1 mutations (3 novel) were identified. Thrombin generation-based assays that enable quantification of the APC- and TFPI-cofactor activities of protein S show that the hypercoagulable states in plasma from type I and III deficient individuals are almost the same. Apparently, the advantage conferred to type III deficient individuals by their higher protein S and TFPI levels was abolished by their older age and higher prothrombin levels. On the basis of the Kaplan-Meier analysis and the functional studies in plasma we conclude that hereditary type I and type III protein S deficiencies are associated with similar risks of venous thrombosis.

We studied the effect of oral contraceptive $(O C)$ use on the down-regulation of thrombin generation by the TFPI and the protein C pathway (Chapter 5). We determined the plasma levels of full length TFPI and total and free protein S in 6 men, 12 women not using OC, 17 women using second and 19 women using third generation OC. The levels of these proteins were correlated with the outcome of functional tests that quantify the TFPI- and APC-cofactor 
activities of protein S. Compared with women who were not using OC, women using second generation OC had significantly lower TFPI-cofactor activities of protein S and higher APCresistance ratios despite that fact that they had similar protein $\mathrm{S}$ levels. This difference is caused by differences in the plasma level of full length TFPI, which is significantly lower in second generation pill users than in non-users. Women using third generation oral contraceptives had even lower TFPI-cofactor activities of protein S and higher APC-resistance ratios than second generation $O C$ users. This difference appeared to be mainly caused by a further decrease in full length TFPI levels and a decrease in protein S level in third generation $\mathrm{OC}$ users. These observations indicate that the anticoagulant TFPI/protein $S$ pathway is impaired in second generation OC users due to a decrease in full length TFPI levels and in third generation OC users due to decreased protein S and TFPI levels. In addition, the lower full length TFPI levels also cause an increase in APC-resistance (Chapter 5). 


\section{SAMENVATTING}

De bloedstolling, ook wel hemostase genoemd, is een complex proces dat aanvangt wanneer de vaatwand wordt beschadigd en weefselfactor wordt blootgesteld aan bloed. De blootstelling van weefselfactor brengt het mechanisme van de bloedstolling op gang dat uiteindelijk uitmondt in de vorming van trombine, de omzetting van fibrinogeen in fibrine en de vorming van een bloedstolsel. In normale omstandigheden vindt geen stolling plaats. In vivo wordt het stollingsproces gereguleerd door antistolingseiwitten die in de bloedsomloop circuleren. Zij verhinderen de vorming van overdreven bloedstolsel en beperken dit bloedstolsel tot de plaats waar het letsel in de vaatwand zich heeft voorgedaan.

Een van deze antistollingseiwitten is proteïne $\mathrm{S}$. Protein $\mathrm{S}$ is een vitamine $\mathrm{K}$ afhankelijk eiwit dat zowel vrij circuleert (40\%) als gebonden is aan C4BP (C4bbindingsproteïne) (60\%) in plasma. Protein S is een cofactor voor APC (geactiveerd protein C) en versnelt hierbij de knip na R306 in factor Va. Algemeen wordt aangenomen dat alleen vrij protein S actief is als cofactor, en dat protein S in complex met C4BP geen cofactor activiteit vertoont voor APC. In dit proefschrift tonen we evenwel aan dat het protein S-C4BP complex wel APC-cofactor activiteit vertoont. Enerzijds wordt de APC gekatalyseerde knip na R306 vertienvoudigd, doch anderzijds wordt de knip na R506 met 3 tot 4 maal verminderd. Protein S daarentegen stimuleert APC gekatalyseerde knip na op positie R306 20 maal, en de knip na R506 wordt niet of nauwelijks gestimuleerd. Het globaal effect van het protein S-C4BP complex op de inactivering van factor Va door APC bedraagt 7 maal minder dan dat van vrij protein S. Dit verschil wordt niet veroorzaakt door een gereduceerde APC-cofactor activiteit van het proteïne S-C4BP complex (APC gekatalyseerde knip op positie R306), doch door remming op de knip na R506 van factor door APC. Deze vaststellingen zijn van bijzonder belang voor dragers van de factor $V_{\text {Leiden }}$ mutatie (positie $R 506 Q$ ), omwille van het feit dat protein S-C4BP complex de inactivering van factor Va (alleen R306) door APC in plasma dat factor VLeiden bevat, daadwerkelijk doet toenemen (Hoofdstuk 2).

Protein S vertoont tevens een antistollende activiteit in afwezigheid van APC (APC onafhankelijke activiteit). Ons laboratorium toonde recent aan dat protein $S$ de trombinevorming doet afnemen in aanwezigheid van TFPI, en zich bijgevolg gedraagt als een cofactor van TFPI. In dit proefschrift beschrijven we twee functionele testen voor het bepalen van de antistollingsactiviteit van het TFPI/protein S systeem in plasma (Hoofdstuk 3). De antistollingsactiviteit van het TFPI/protein S systeem in plasma wordt bepaald door de trombinevorming in aan- en afwezigheid van neutraliserende antilichamen tegen protein $\mathrm{S}$ of 
TFPI. In beide testen werd gebruikt gemaakt van gecalibreerde geautomatiseerde trombografie (CAT) om de trombinevorming te meten, waarbij een typische trombinecurve bekomen werd. Deze test werd eerst uitgevoerd in plasma van 85 normale individuen die werden verzameld aan de universiteit van Maastricht. De verhouding van de pieken van de trombinecurve die werden gemeten in aan- en afwezigheid van anti-protein $\mathrm{S}$ antiflichamen (protein S-ratio) en die 0.5 bedroeg in gepoold normal plasma, staat in verhouding tot de TFPI cofactor activiteit van protein S. De TFPI-ratio van normaal plasma bedroeg ongeveer 0.25 , hetgeen betekent dat de trombinevorming in plasma wordt gereduceerd met $75 \%$ als gevolg van het TFPI/protein S antistollingssystem. De protein S- en TFPI-ratio's werden ook gemeten bij 35 leden van protein S deficiënte families afkomstig uit Italië. Beide ratio's waren aanzienlijk hoger bij patiënten die heterozygoot waren voor type I protein S deficiëntie dan bij hun niet-deficiënte familieleden. De protein S- en TFPI- ratio's stonden duidelijk in verhouding tot de hoeveelheid TFPI in plasma zoals bepaald door middel van een nieuw ontwikkelde ELISA. De protein S-ratio stond alleen in verhouding tot de hoeveelheid protein S in plasma bij de protein $\mathrm{S}$ deficiënte individuen. Een verlaagde activiteit van het TFPI/protein $\mathrm{S}$ antistollingssysteem zou kunnen bijdragen tot een verhoogd risico op veneuze trombose bij deze protein S-deficiënte individuen (Hoofdstuk 3).

De cofactor activiteit van protein S voor APC en TFPI werd ook onderzocht bij een grotere populatie heterozygote proteïne $S$ deficiënte patiënten (Hoofdstuk 4). Epidemiologische, genetische en functionele studies werden uitgevoerd in plasma van protein S deficiënte families met het oog op het bepalen van het risico op trombose bij type I en type III protein S deficiënties. Type I protein S deficiëntie wordt gekarakteriseerd door een laag totaal en een lage hoeveelheid vrij protein $S$ en type III deficiënte individuen hebben een normaal totaal en een lage hoeveelheid vrij protein S in plasma. De Kaplan-Meier test bij 242 individuen die deel uitmaakten van 30 families toonde aan dat de kans voor trombose voor type I en type III protein S deficiënte individuen gelijklopend is. Van deze Kaplan-Meier test, werden 23 families (132 individuen) verder onderzocht teneinde deze vaststelling te verklaren. Bij deze families werden 11 PROSI mutaties in het gen van protein S geïdentificeerd. Testen gebaseerd op trombinevorming die de bepaling van de cofactor activiteit van de protein S voor APC en TFPI mogelijk maken, tonen aan dat de verhoogde kans op stolling in plasma voor type I en type III deficiënte individuen bijna dezelfde is. Alhoewel type III deficiënte individuen beschikten over een hogere hoeveelheid protein S en TFPI in plasma, leek dit te worden tenietgedaan door hun hogere leeftijd en hogere hoeveelheid protrombine in plasma. Op basis van de Kaplan-Meier analyse en de functionele onderzoeken in plasma 
concluderen we dat type I en type III protein S deficiëntie gepaard gaan met gelijkaardige risico's op veneuze trombose.

Tenslotte bestudeerden we het effect van het gebruik van de anticonceptiepil op verminderde cofactor activiteit van protein S voor TFPI en APC door het meten van trombinevorming (Hoofdstuk 5). We bepaalden de hoeveelheid TFPI, totaal en vrij protein S in plasma van 6 mannen, 12 vrouwen die geen anticonceptiepil gebruikten, 17 vrouwen die een anticonceptiepil van de tweede generatie gebruikten en 19 vrouwen die een anticonceptiepil van de derde generatie gebruikten. De hoeveelheden TFPI en protein S in plasma vertoonden een verband met het resultaat van functionele testen die de TFPI en APC cofactor activiteit van protein $\mathrm{S}$ bepalen. Ten opzichte van vrouwen die geen anticonceptiepil gebruikten, hadden vrouwen die een anticonceptiepil van de tweede generatie gebruikten, een beduidend lagere TFPI en APC cofactor activiteit van protein S, ondanks het feit dat zij een gelijkaardige hoeveelheid protein S in plasma hadden. Dit verschil wordt veroorzaakt door verschillen in de hoeveelheid TFPI in plasma, dat aanzienlijk lager is bij gebruiksters van een tweede generatie anticonceptiepil, dan bij niet-gebruiksters. Vrouwen die een anticonceptiepil van de derde generatie gebruikten hadden nog lagere TFPI en APC cofactor activiteit van protein $\mathrm{S}$ dan gebruiksters van een anticonceptiepil van de tweede generatie. Dit verschil leek voornamelijk veroozaakt te worden door een verdere afname van TFPI en protein $S$ niveau in plasma van gebruiksters van een derde generatie anticonceptiepil. Deze vaststellingen tonen aan dat de antistollingsactiviteit van het TFPI/protein S systeem nadelig wordt beïnvloed door het gebruik van een tweede generatie anticonceptiepil als gevolg van een afname TFPI en door het gebruik van een derde generatie anticonceptiepil als gevolg van een daling van de protein S en TFPI in plasma. Daarenboven veroorzaken de lagere hoeveelheden TFPI in plasma tevens een daling van de antistollingsactiviteit van APC (hoofdstuk 5). 


\section{CURRICULUM VITAE}

De auteur van dit proefschrift werd op 14 mei 1980 geboren in Bilzen. Na het verlaten van de plaatselijke basisschool in Membruggen Riemst, startte zij in het najaar van 1992 haar middelbare school opleiding aan het humaniora van de onbevlekte ontvangenis te Tongeren en in 1998 behaalde zij aldaar het diploma Wiskunde-Wetenschappen. Vervolgens startte zij haar kandidaturen Scheikunde aan de Katholieke Universiteit Leuven, welke werden afgerond in 2001. In 2003 behaalde zij het diploma Licentiaat in de Biochemie. Op 1 april 2004 startte zij als promovendus binnen het Cardiovascular Research Institute Maastricht aan de Universiteit van Maastricht. Bij de capaciteitsgroep Biochemie deed zij de daaropvolgende jaren, onder leiding van Prof. Dr. J Rosing (promotor) en Prof. Dr. T Hackeng onderzoek naar de antistollingsactiviteiten van proteïne $S$, hetgeen uiteindelijk tot dit proefschrift heeft geleid. Momenteel is zij werkzaam als postdoctoraal onderzoeker binnen het GIGA research institute aan de Universiteit van Luik bij de vakgroep immunologie en infectieuze ziektes onder leiding van Prof. Dr. M Moutchen en Dr. S Rahmouni. 


\section{LIST OF PUBLICATIONS}

Maurissen LF , Thomassen M C, Nicolaes G A, Dahlbäck B, Tans G, Rosing J, and Hackeng T M. Re-evaluation of the role of the protein $\mathrm{S}-\mathrm{C} 4 \mathrm{~b}$ binding protein complex in activated protein $\mathrm{C}$ catalyzed factor Va-inactivation. Blood. 2008; 111: 3034-3041

Rosing J, Maurissen LF, Tchaikovski SN, Tans G, Hackeng TM. Protein S is a cofactor for tissue factor pathway inhibitor. Thromb Res. 2008; 122 Suppl 1: S60-3. Review

\section{LIST OF PUBLISHED ABSTRACTS}

46th Annual Scientific Meeting of the British Society for Haematology incorporating the Netherlands and British Haemostasis and Thrombosis Societies (Edinburgh, April 2006).

Maurissen LFA, Thomassen MCLGD, Rosing J, Hackeng TM.

Protein S-C4BP complex inhibits APC-mediated cleavage of factor Va at R506 but stimulates cleavage at R306 British Journal of Haematology, 133 (Suppl. 1), 2006

$\underline{X X{ }^{s t} \text { Congres of the International Society on Thrombosis and Haemostasis (Geneva, July 2007) }}$

Maurissen LFA, Thomassen MCLGD, Nicolaes GF, Dahlbäck B, Tans G, Rosing J, Hackeng TM. Protein S-C4BP complex stimulates activated protein C mediated inactivation at R306 but inhibits inactivation at R506 in factor Va. Journal of Thrombosis and Haemostasis, 5 (Suppl. 2), 2007

\section{AWARDS}

Young Investigator Award of the Dutch Society of thrombosis and Haemostasis, Annual Scientific Meeting of the Dutch Society of Thrombosis and Haemostasis, Koudekerke, The Netherlands (2007). 


\section{DANKWOORD}

Dit proefschrift is tot stand gekomen dankzij de inzet en steun van velen. Een woord van dank is hier dan ook meer dan op zijn plaats. In tegenstelling tot hetgeen jullie van mij zouden verwachten, zal ik het kort houden: woorden schieten sowieso te kort ... .

Tilman, jij hebt mij de kans gegeven om vier fantastische jaren te mogen beleven in Maastricht. Ik kon altijd bij je aankloppen, de deur stond altijd open. Jouw eeuwige optimisme en gedrevenheid waren voor mij immer een bron van motivatie. Je slaagde er steeds weer in om positieve conclusies te trekken uit faliekant afgelopen experimenten. Het is voor mij een eer om als eerste AIO van Professor Hackeng te mogen promoveren.

Jan, ik ben zeer verheugd dat ik binnen jouw vakgroep en onder jouw leiding wetenschappelijk onderzoek heb mogen verrichten. Jouw hoge eisen en kritisch blik deden bij mij grote ogen opengaan. Op de talrijke borrels kon ik altijd genieten van de verhalen die je vertelde. ledereen kon steeds bij jou terecht wanneer er zich een probleem stelde. Ik wil je hartelijk danken voor de hulp tijdens de laatste maanden.

Guido, hoewel je vele verantwoordelijkheden buiten het lab hebt, een werkbespreking op donderdag zonder jou is geen werkbespreking. Ik bewonder jouw veelzijdigheid en kennis over alles wat ook niet met stolling te maken heeft. De weinige keren dat ik met jou data mocht analyseren hebben mij des te meer bijgebracht.

Gerry, jouw humor wist ik altijd te appreciëren, jouw "Hollandse schlager muziek" minder.

Betta, hoewel je inmiddels naar een andere kamer bent verhuisd, voor mij was je de belangrijkste persoon binnen onze kamer. Ik kon altijd 101 vragen op je afvuren, je was altijd een luisterend oor. Vloeken was op onze "deftige" kamer dankzij jou niet toegelaten. Ik ga je zeker missen, mille gracie!

Mijn beste Kenneth, vele mooie tijden hebben wij beleefd binnen en buiten het lab, een echte vriendschap is het gevolg. Ik kan me dan ook geen betere paranimf inbeelden. Ik wens je veel geluk met Elke en in jouw verdere carrière.

Wencke, mijn tweede paranimf, ik vond het enorm jammer toen je verhuisde naar Eindhoven. Het betekende het einde van onze gezellige babbels over van alles en nog wat. 
Mijn kamergenootjes Svetlana, Connie en Olivier, ik wil jullie bedanken voor de gezellige tijden. Svetlana, ik bewonder jouw sterke wil en jouw doorzettingskracht bij het studeren van de Nederlandse taal. Connie, altijd even serieus, veel succes. "Don Juan" Olivier, veel succes. Ook de nieuwe AIO's, Kristien en Samira, en de nieuwe post-docs, Pieter en Mahesh, ik wens jullie veel succes.

Ook mijn voorgangers wil ik graag bedanken. Rory, hoewel je reeds was vertrokken toen ik van start ging, kon ik voor mijn vele vragen ook bij jou terecht. Jeroen, fijne momenten hebben wij met jou beleefd in het lab. Kristien, vaak heb ik mij afgevraagd hoe jij die proeven steeds weer voor mekaar kreeg en ik niet.

Stella, jou zou ik niet durven vergeten. Ons lab is waar Stella staat. Jij bent de kampioen van de feestjes, maar de morgen nadien ben je ook van de partij. Graag had ik jouw geheim recept gekend.

Trees, jij bent de beste secretaresse die een mens zich kan inbeelden.

Kim, Sandra en Imke, mijn vriendinnekes van de gang, iedereen van de vakgroep Biochemie, van harte bedankt.

Dr. Rahmouni, dear Souad, dr. Moutschen, and all my new collegues, thank you that I can join your group.

Graag wil ik Nodia, Thrombinoscope NV, Zebrabioscience, Kordia en Sanquin reagentia bedanken voor hun financiële bijdrage voor het drukken van dit proefschrift.

Jan bedankt voor het ontwerp van de cover.

Tenslotte wil ik graag mijn familie en schoonfamilie bedanken voor hun steun en de interesse die ze altijd in mij getoond hebben. Onze zonnetjes in huis, Mieke, Maggy en James, hopelijk mag ik jullie nog lang vele knuffels geven. Mama, veel uitleg gaf ik je nooit over mijn bezigheden, toch bleef je mij steunen, dank voor de kansen die ik kreeg. Ook al verhuis ik dit jaar naar de grote stad, mijn thuis blijft in Membruggen. Ann, mijn zus, ik weet dat je altijd het beste voor mij wilt. Dank om mij te stimuleren tijdens de moeilijke momenten.

En last but not least, Jan. Mijn succes is jouw succes, ik hoop ook het omgekeerde. Ik heb het je niet altijd even gemakkelijk gemaakt, zeker niet het afgelopen jaar, zelfs tot gisteren. Woorden schieten mij tekort. Dikke kus. 
